\title{
1985 Consumer Segmentation; Assessment of the Market for Conservation in the Northwest: Phase II
}
B. M. Bailey
R. T. Nordi
M. P. Hattrup
S. A. Shankle
D. L. Ivey, Project Manager

May 1987

Prepared for the

Bonneville Power Administration

Office of Conservation under a Related Services Agreement with the U.S. Department of Energy

Contract DE-AC06-76RLO 1830

Pacific Northwest Laboratory Operated for the U.S. Department of Energy by Battelle Memorial Institute 


\section{DISCLAIMER}

This report was prepared as an account of work sponsored by an agency of the United States Government. Neither the United States Government nor any agency thereof, nor Battelle Memorial Institute, nor any of their employees, makes any warranty, expressed or implied, or assumes any legal liability or responsibility for the accuracy, completeness, or usefulness of any information, apparatus, product, or process disclosed, or represents that its use would not infringe privately owned rights. Reference herein to any specific commercial product, process, or service by trade name, trademark, manufacturer, or otherwise, does not necessarily constitute or imply its endorsement, recommendation, or favoring by the United States Government of any agency thereof, or Battelle Memorial Institute. The views and opinions of authors expressed herein do not necessarly state or reflect those of the United States Government or any agency thereof, or Battelle Memorial Institute.

\section{PACIFIC NORTHWEST LABORATORY operated by \\ BATTELLE MEMORIAL INSTITUTE for the \\ UNITED STATES DEPARTMENT OF ENERGY under Contract DE-AC06-76RLO 1830}

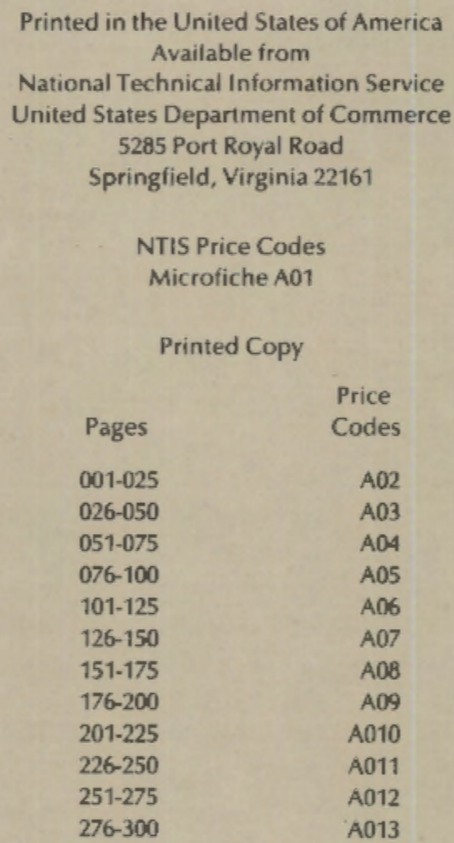


1985 CONSUMER SEGMENTATION; ASSESSMENT OF THE MARKET FOR CONSERVATION IN THE NORTHWEST: PHASE II

B. M. Bailey

M. P. Hattrup

R. T. Nordi

S. A. Shankle

D. L. Ivey, Project Manager

May 1987

Prepared for the

Bonneville Power Administration Office of Conservation under a Related Services Agreement with the U.S. Department of Energy Contract DE-AC06-76RLO 1830

Pacific Northwest Laboratory

Richland, Washington 99352 
$\checkmark$

. 
PREFACE

In October and November, 1985 a telephone survey of 1058 households in the Pacific Northwest was conducted as part of a project to analyze the marketing environment for conservation activities of the Bonneville Power Administration (BPA). Analyses of the survey results are being published in a series of five reports :

- a tracking report analyzing the changes between 1983 and 1985

- a financing report focusing on the funding aspects of household energy conservation investments

- a consumer characterization and segmentation report with detailed analyses of market segments

- a fuel switching report detailing the changes in primary and secondary fuel sources in home heating

- a utility summary report presenting a summary of the above four reports with an emphasis on electrical utilities.

The work on this series of reports is conducted by Pacific Northwest Laboratory (PNL) in support of BPA's efforts to develop the capability in delivering conservation programs for use in the future when it becomes necessary to acquire conservation resources. BPA's technical monitor for the project has been Terry 01 iver, Office of Conservation.

This report, entitled 1985 Consumer Segmentation; Assessment of the Market for Conservation in the Northwest: Phase II, is the third report in the series. It presents information on consumer attitudes toward conservation, past and intended conservation behaviors, and utility-sponsored conservation program participation levels. The report is based entirely on the 1985 survey data. Comments and suggestions on this report are welcome. Please direct your correspondence to: D. L. Ivey, Project Manager, Pacific Northwest Luboratory, P.0. Box 999, Richiand, Washington 99352. 
. 


\section{EXECUTIVE SUMMARY}

This report presents information on consumer attitudes toward conservation, past and intended conservation behaviors, and utility-sponsored conservation program participation levels. The information was collected by means of random telephone surveys of househoids in Idaho, Oregon, Washington, and Western Montana. Pacific Northwest Laboratory (PNL) conducted analyses of the survey results for the Bonnevilie Power Administration (BPA) to obtain a better understanding of consumer attitudes and behaviors and to facilitate conservation program planning, design, and marketing.

Coverage and Hypotheses

This report covers the following hypotheses:

- Repeat investors in energy conservation measures (ECMs) will need a greater incentive to invest in additiona $\mathrm{ECMs}$ than will other groups of consumers.

- Consumer behavior and intentions toward conservation will not vary by participation in utility-sponsored conservation programs.

- Consumer behavior and intentions toward conservation will not vary by expected benefits.

- Consumer behavior and intentions toward conservation will not vary by demographicaliy defined groups.

- Consumer behavior and intentions toward conservation will not vary by value, attitude and lifestyie (VALs) questions or family iffe-cycie defined segments.

- The amount of money spent on ECMs will not vary by homeowners' perceptions of conservation

- The primary barriers to conservation investment are noneconomic. In the following section, major findings for each hypothesis are presented. 
PAST CONSERVATION BEHAVIOR AND THE NEED FOR INCENTIVES TO INVEST FURTHER

Homeowners who have purchased and/or invested in more than one ECM appear from the analyses to have high incomes, live in single-detached homes, report receiving unexpected monetary benefits from their conservation investments, and report utility and bank loans as potential funding sources for conservation investments. The hypothesis, that repeat purchasers will need more of an incentive to invest further in conservation measures can be rejected. This segment is more financially able to invest and appear to invest for reasons other than monetary benefits.

\section{PARTICIPATION IN UTILITY SPONSORED CONSERVATION PROGRAMS}

Homeowners that had participated in at least one conservation program appeared to have invested in slightly more conservation measures in the past than homeowners that had not participated in any programs. Also when comparing homeowners who had participated in a utility sponsored program with those who had not, those homeowners who had participated indicated a greater likelihood of investing in three or more measures during the next two to three years. The results indicate that consumer behavior and intentions toward conservation investment vary by participation in a utility sponsored conservation program. These results in turn support rejecting the hypothesis that behavior and intention would not vary by participation in such programs.

\section{EXPECTED BENEFITS OF ENERGY CONSERVATION MEASURES}

Households that had previously installed ECMs had expected monetary as weil as comfort benefits. These expectations changed when respondents were asked about future ECM installation in the next two to three years. For more than three-fourths of the ECMs, respondents reported that they expect to receive primarily monetary benefits. The results seem to give some support to rejecting the hypothesis that consumer behavior and intentions do not vary by the benefits expected from different ECMs. 
DEMOGRAPHIC INFLUENCES ON CONSERVATION INVESTMENT

It was hypothesized that consumer behavior and intentions toward installation of energy conservation measures would not vary by demographically defined groups. The results indicate that certain demographic variables do in fact have an effect both on past behavior and future plans to install ECMs. Therefore, the hypothesis can be partially rejected. Of the seven demographic variables used to test the hypothesis, five had some degree of influence. These five include total household income, education level, number of people in the household, length of occupancy in the current residence, and geographic location.

INFLUENCE OF ATTITUDES AND FAMILY LIFE CYCLE SEGMENTS ON CONSERVATION INVESTMENT

The results of the analyses indicate that consumer behavior and intentions toward conservation do vary by the family life cycle a household currently finds itself. The two life cycle segments that appear most receptive and capable of installing ECMs are the Young Adults-Childless and Early Parenthood. These segments have moderately high incomes, shorter length of stay at current residences, fewer ECMs installed, and the greatest likelihood of installing three or more ECMs in the future. Marketing programs should be geared towards the demographic data available on these two segments.

A statistical procedure call Factor Analysis was used to analyze the value, attitude and lifestyle statements in the Phase II survey. The analysis indicated that there were two factors which measured the levels of cynicism and altruism that homeowners may have felt toward several of the statements. The results seem to indicate that consumer behavior and intentions toward conservation do vary by the respondents responses to the attitude statements.

PERCEPTUAL INFLUENCES ON THE AMDUNT OF MONEY SPENT FDR ENERGY CONSERVATION MEASURES

Respondents were asked about their level of concern for energy use in the home, cost of energy and energy conservation. The results showed that in general, as concern for an issue increased so did the level of conservation 
spending. The respondents were also asked to respond to several attitudinal statements. It became apparent that those who spent nothing were more likely to give negative responses while those who spent something on energy conservation tended to give more positive results. The hypothesis which was tested states, that the amount of money spent on ECMs will not vary by homeowners' perception of conservation. The findings indicate that the hypothesis should be rejected.

PERCEIVED BARRIERS TO ENERGY CONSERVATION INVESTMENT

It was hypothesized that the primary barriers to homeowner investment in ECMs are noneconomic. The results of the analyses overwhelmingly show that the primary barriers to investment in ECMs are economic. Neariy 60\% of the homeowners stated that cost was the primary barrier to conservation investment. The next most frequent reason given for not investing was that homeowners felt no need to invest. This may be true for some of the residences. However, a reiatively large segment of these homeowners may not be aware that certain ECMs can reduce energy use and still be cost effective. 


\section{CONTENTS}

PREFACE

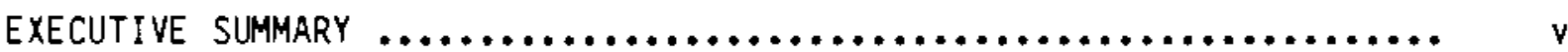

PAST CONSERVATION BEHAVIOR ANO THE NESD FOR INCENTIVES

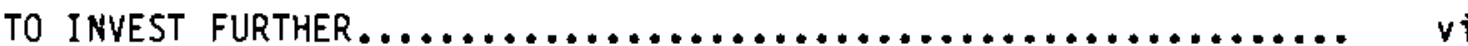

PARTICIPATION IN UTILITY SPONSORED CONSERVATION PROGRAMS........ vi

EXPECTED BENEFITS OF ENERGY CONSERVATION MEASURES............ vi

DEMOGRAPHIC INFLUENCES ON CONSERVATION INVESTMENT ............ vii

INFLUENCE OF ATTITUOES AND FAMILY LIFE CYCLE SEGMENTS ON

CONSERVATION INVESTMENT ............................ Vii

PERCEPTUAL INFLUENCES ON THE AMOUNT OF MONEY SPENT FOR

ENERGY CONSERVATION MEASURES........................ vii

PERCEIVED BARRIERS TO ENERGY CONSERVATION INVESTMENT........... vi

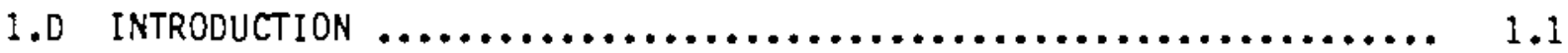

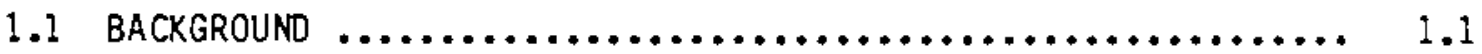

1.2 SURVEY AND SAMPLE DESCRIPTIONS $\ldots \ldots \ldots \ldots \ldots \ldots \ldots \ldots \ldots \ldots \ldots \ldots$

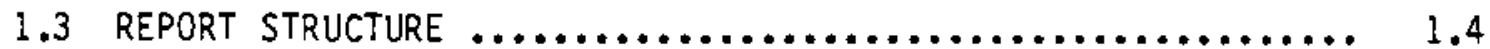

2.0 FINDINGS $\ldots \ldots \ldots \ldots \ldots \ldots \ldots \ldots \ldots \ldots \ldots \ldots \ldots \ldots \ldots \ldots \ldots \ldots \ldots \ldots \ldots \ldots \ldots$

2.1 PAST CONSERVATION BEHAVIOR AND THE NEEO FOR INCENTIVES

TO INVEST FURTHER ............................... 2.1

2.2 PARTICIPATION IN UTILITY SPONSORED CONSERVATION

PROGRAMS ........................................ 2.1

2.3 EXPECTED BENEFITS OF ENERGY CONSERVATION MEASURES ......... 2.2

2.4 DEMOGRAPHIC INFLUENCES ON CONSERVATION INVESTMENT ........ 2.3

2.5 INFLUENCE OF ATTITUDES AND FAMILY LIFE CYCLE SEGMENT

ON CONSERVATION INVESTMENT ....................... 2.4

2.6 PERCEPTUAL INFLUENCES ON THE AMOUNT OF MONEY SPENT

FOR ENERGY CONSERVATION MEASURES.................... 2.6

2.7 PERCEIVED BARRIERS TO ENERGY CONSERVATION INVESTMENT $\ldots \ldots \ldots .2 .6$ 
3.0 PURCHASE BEHAVIOR OF HOMEOWNERS $\ldots \ldots \ldots \ldots \ldots \ldots \ldots \ldots \ldots \ldots \ldots, 3.1$

3.1 DEMOGRAPHIC FACTORS THAT INFLUENCE PURCHASE BEHAVIOR $\ldots \ldots . .3 .1$

3.2 Other factors that influence PURChase behaviOR $\ldots \ldots \ldots \ldots \ldots .3 .3$

3.3 HOMEOWNERS' ATTITUDES THAT INFLUENCE PURCHASE BEHAVIOR $\ldots . . .3 .11$

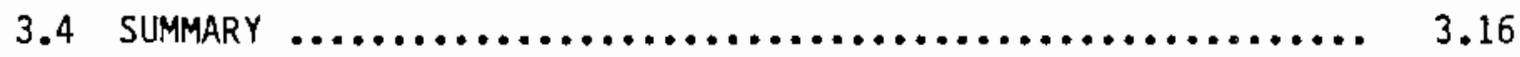

4.0 UTILITY CONSERVATION PROGRAM PARTICIPATION $\ldots \ldots \ldots \ldots \ldots \ldots \ldots . . . \ldots .1$

4.1 AWARENESS OF UTILITY CONSERVATION PROGRAMS $\ldots \ldots \ldots \ldots \ldots \ldots . . . . .1$

4.2 PARTICIPATION IN UTILITY CONSERVATION PROGRAMS $\ldots \ldots \ldots \ldots \ldots . . .4 .9$

4.3 RELATIONSHIP BETWEEN PARTICIPATION IN UTILITY

CONSERVATION PROGRAMS AND CONSERVATION

INVESTMENT BEHAVIOR $\ldots \ldots \ldots \ldots \ldots \ldots \ldots \ldots \ldots \ldots \ldots \ldots \ldots, 4.10$

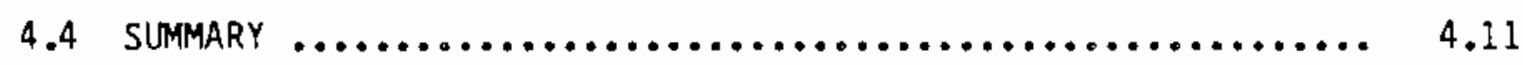

5.0 EXPECTED BENEFITS OF ENERGY CONSERVATION MEASURES $\ldots \ldots \ldots \ldots \ldots \ldots . .1$

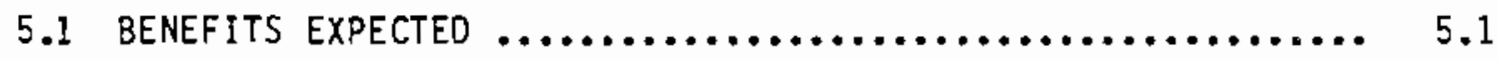

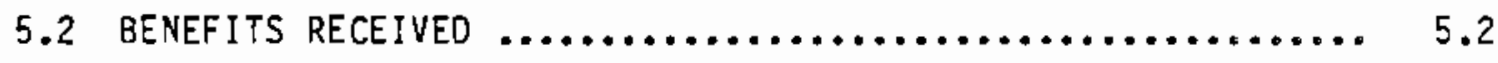

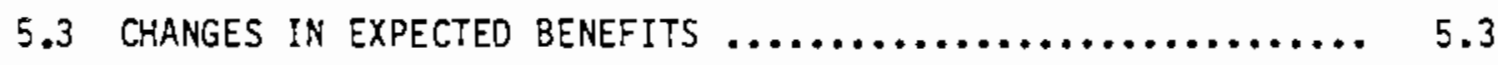

5.4 BENEFITS EXPECTED BY RESPONDENTS SOMEWHAT OR VERY
LIKELY TO INSTALL ENERGY CONSERVATION MEASURES $\ldots \ldots \ldots \ldots$.

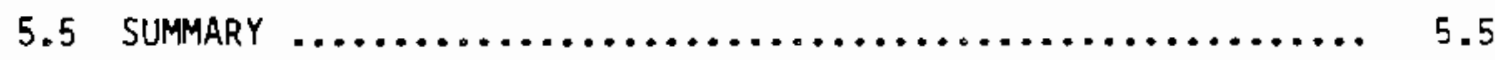

6.0 DEMOGRAPHIC INFLUENCES ON PAST AND FUTURE ENERGY
CONSERVATION BEHAVIOR $\ldots \ldots \ldots \ldots \ldots \ldots \ldots \ldots \ldots \ldots \ldots \ldots \ldots \ldots \ldots \ldots \ldots \ldots \ldots \ldots$

6.1 DEMOGRAPHIC INFLUENCES ON ENERGY CONSERVATION BEHAVIOR $\ldots . . .6 .1$

6.1 .1 Length of Time at Current Residence .............. 6.1

6.1.2 Number of Occupants in Residence ............... 6.3

6.1 .3 Occupation of the Homeowner $\ldots . . \ldots \ldots \ldots \ldots \ldots . .6 .4$

6.1 .4 Occupation of the Second Householder $\ldots \ldots \ldots \ldots \ldots .6 .6$

6.1 .5 Educationat Level of Househoid ................. 6.8 


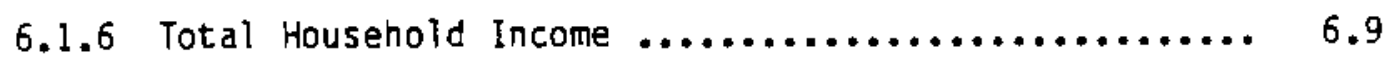

6.1.7 Geographic Location of the Survey Residence ........ 6.10

6.1.8. A Characteristics of Homeowners in the Low Installation Activity Level .................. 6.12

6.1.8.B Characteristics of the Subset of Homeowners with Electric Heat in the Low Installation Activity Level

6.1.9. A Characteristics of All Homeowners in the Medium-Low Installation Activity Level .......... 6.13

6.1.9.B Characteristics of the Subset of Homeowners with Electric Heat in the Medium-Low Installation Activity Level

6.1.10. A Characteristics of All Homeowners in the Medium-High Installation Activity Level .......... 6.14

6.1.10.B Characteristics of the Subset of Homeowners with Electric Heat in the Medium-High Installation Activity Level

6.1.11. A Characteristics of All Homeowners in the High Installation Activity Level ............... 6.16

6.1.11. B Characteristics of the Subset of Homeowners with Electric Heat in the High Installation Activity Level

6.2 DEMOGRAPHIC INFLUENCES ON LIKELIHOOD OF FUTURE INSTALLATION OF ENERGY CONSERVATION MEASURES $\ldots \ldots \ldots \ldots \ldots \ldots, 6.17$

6.2.1 Length of Time at Current Residence .............. 6.17

6.2.2 Number of Occupants in Residence ................ 6.18

6.2.3 Educational Levei of the Household ................ 6.19

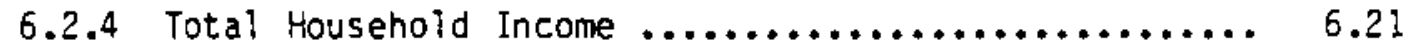

6.2.5 Geographic Location of the Survey Residence ........ 6.22

6.2.6.A Characteristics of AIl Homeowners Not Likely to Instail Energy Conservation Measures .......... 6.23

6.2.6.B Characteristics of the Subset of Homeowners with Electric Heat Who Are Not Likely to Install Energy Conservation Measures 
6.2.7. A Characteristics of All Homeowners Likely to Install One or Two Energy Conservation

Measures ................................... 6.24

6.2.7. B Characteristics of the Subset of Homeowners with Electric Heat Who Are Likely to Install

1 to 2 Energy Conservation Measures ............. 6.25

6.2.8. A Characteristics of All. Homeowners Likely to Install Three or More Energy Conservation

Measures .................................. 6.25

6.2.8. B Characteristics of the Subset of Homeowners with Electric Heat Who Are Likely to Install

Three or More Energy Conservation Measures ....... 6.26

6.3 SUMMARY OF FINDINGS IN CHAPTER $6 \ldots \ldots \ldots \ldots \ldots \ldots \ldots \ldots \ldots, 6.26$

7.0 SEGMENTATION BY FAMILY LIFE CYCLE AND VALUE, ATTITUDE

AND LIFESTYLE STATEMENTS $\ldots \ldots \ldots \ldots \ldots \ldots \ldots \ldots \ldots \ldots \ldots \ldots \ldots \ldots \ldots \ldots \ldots \ldots \ldots, 1$

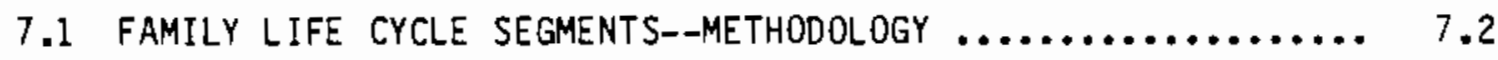

7.2 DEMOGRAPHIC BREAXDOWN OF FAMILY LIFE CYCLE SEGMENTS $\ldots \ldots \ldots .7 .3$

7.3 FAMILY LIFE CYCLE SEGMENTS AND CONSUMER BEHAVIOR

AND INTENTIONS TOWARD CONSERVATION INVESTMENT $\ldots \ldots \ldots \ldots \ldots . . . .1 .10$

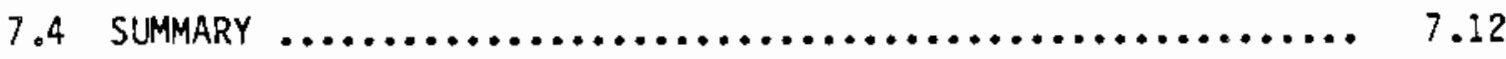

7.5 VALUE, ATTITUDE AND LIFESTYLE SEGMENTS--METHODOL OGY $\ldots . . . .7 .13$

7.6 DEMOGRAPHIC BREAKDOWN OF CYNICISM AND ALTRUISM FACTORS $\ldots \ldots .7 .14$

7.7 CYNICISM AND ALTRUISM FACTORS RELATED TO CONSUMER
BEHAVIOR AND INTENTIONS TOWARD ENERGY CONSERVATION $\ldots \ldots \ldots$.

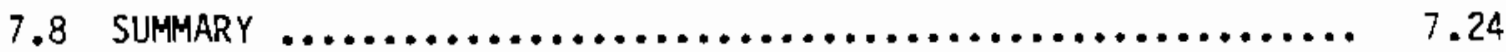

8.0 INFLUENCE OF HOMEOWNER' PERCEPTIONS AND ATTITUDES ON ENERGY

CONSERVATION INVESTMENT $\ldots \ldots \ldots \ldots \ldots \ldots \ldots \ldots \ldots \ldots \ldots \ldots \ldots \ldots \ldots \ldots, 8.1$

8.1 INFLUENCES OF HOMEOWNERS' PERCEPTIONS OF CONSERVATION

ON SPENDING FOR ENERGY CONSERVATION .................... 8.1

8.1.1 Level of Concern for Energy Use in the Home ....... 8.1

8.1 .2 Level of Concern for Cost of Energy $\ldots \ldots \ldots \ldots \ldots \ldots .6 .2$

8.1.3 Level of Concern for Energy Conservation ........... 8.4 
8.2 INFLUENCES OF HOMEOWNERS' ATTITUDES TOWARDS CONSERVATION ON SPENDING FOR ENERGY CONSERVATION

8.2.1 Attitude Toward the Amount of Energy Used ......... 8.5

8.2.2 Attjtude Toward the Amount of Electricity Used ..... 8.6

8.2.3 Attitude Toward Ability to Conserve Energy ........ 8.8

8.2.4 Attitude Toward Consulting Consumer Reports ........ 8.8

8.2.5 Attitude Toward Utilities Offering Conservation

Programs ................................... 8.10

8.2.6 Attitude Toward Improving the Efficiency of Their Home .................................. 8.12

8.2.7 Attitude Toward Electricity Prices in the Northwest ............................... 8.12

8.2.8 Attitude Toward Electricity Rate Changes .......... 8.14

8.2.9 Attitude Toward Power Surplus ................ 8.16

8.2.10 Attitude Toward the Effect of Conservation Efforts ................................. 8.16

8.2.11 Attitude Toward Protecting the Environment ......... 8.19

8.2.12 Attitude Toward Conserving Electricity for Future

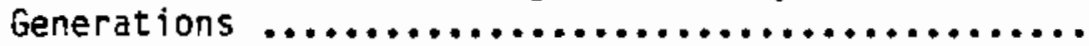

8.2.13 Attitude Toward Conserving Electricity to Save Money ................................... 8.2I

8.2.14 Attitude Toward Conservation Improving value of Their Home ............................. 8.21

8.2.15 Attitude Toward Conservation Increasing the Comfort of the Home ......................... 8.23

8.3 SUMMARY OF FINDINGS IN THE CHAPTER $\ldots \ldots \ldots \ldots \ldots \ldots \ldots \ldots \ldots . \ldots . \ldots \ldots$

9.0 BARRIERS TO ENERGY CONSERVATION INVESTMENT $\ldots \ldots \ldots \ldots \ldots \ldots \ldots \ldots \ldots . . . . . . . .$.

9.1 REASONS NOT TO INVEST IN CONSERVATION MEASURES............ 9.1

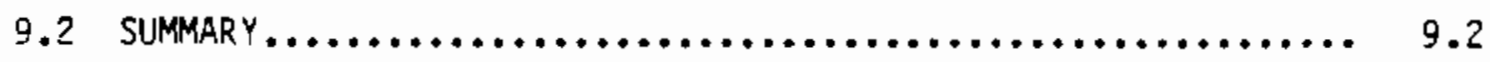




\section{FIGURES}

4.1.A Aware of Utility Conservation Programs, All Heating Fuels .... 4.2

4.1.B Aware of Utility Conservation Programs, Heating Fuel

Electric

4.2

4.2. A Aware of Federal Energy Guide Labels, All Heating Fuels ..... 4.7

4.2.8 Aware of Federal Energy Guide Labels, Heating Fuel

Electric ....................................... 4.7

4.3. A Aware of Coior of Energy Guide Label, All Heating Fuels ..... 4.8

4.3.B Aware of Color of Energy Guide Label, Heating Fuel

Electric

4.8

4.4.A Participation in Utility Conservation Programs,

All Heating Fuels

4.4.B Participation in Utility Conservation Programs, Heating

Fuel Electric ....................................... 4.13

5.1.A Benefits Expected from Weatherproofing, All Heating Fuels .... 5.6

5.1.B Benefits Expected from Weatherproofing, Heating Fuel

Electric ......................................... 5.6

5.2.A Benefits Expected from Storm Windows, ATl Heating Fueis ..... 5.7

5.2.B Benefits Expected from Stom Windows, Heating Fue 1

Electric ....................................... 5.7

5.3.A Benefits Expected from Heat Pump/Furnace, A11 Heating

Fuels ........................................... 5.8

5.3.B Benefits Expected from Heat Pump/Furnace, Heating Fuel

Electric ......................................... 5.8

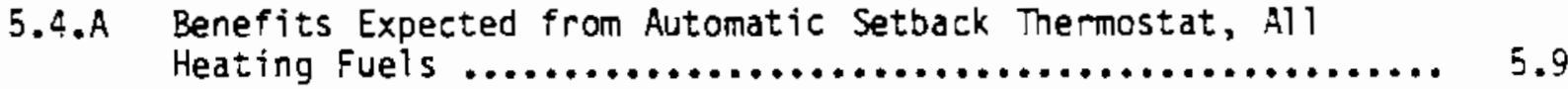

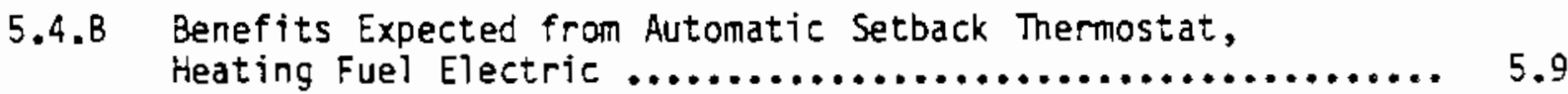

5.5.A Benefits Expected from Insulated Basement Floor/Crawl

Space, Al1 Heating Fuels ............................ 5.10

5.5.B Benefits Expected from Insulated Basement Floor/Crawl

Space, Heating Fuel Electric 
5.6.A Benefits Expected from Insulated Outside Walls, All Heating Fuels

5.6.B Benefits Expected from Insulated Outside Walls, Heating

Fuel Electric

5.7.A Benefits Expected from Insulated Roof or Attic, All Heating Fuels

5.7.8 Benefits Expected from Insulated Roof or Attic, Heating

Fuel Electric

5.8.A Benefits Expected from Solar Panels, All Heating Fuels ........

5.8.B Benefits Expected from Solar Panels, Heating Fuel

Electric

5.9.A Benefits Expected from Storm or Insulated Doors, All

Heating Fuels

5.9.B Benefits Expected from Storm or Insulated Doors, Heating

Fuel Electric

5.14

5.10.A Benefits Expected from Heat Pump Water Heaters, All Heating Fuels

5.10.B Benefits Expected from Heat Pump Water Heaters, Heating

Fuel Electric

5.11.A Benefits Expected from Wood Stoves, All Heating Fuels ....... 5.16

5.11.8 Benefits Expected from Wood Stoves, Heating Fuel Electric .... 5.16

5.12.A Benefits Expected from Fireplace Inserts, Ail Heating

Fuels

5.12.B Benefits Expected from Fireplace Inserts, Heating Fuel Electric

5.13.A Benefits Expected by Homeowners who Are Somewhat or Very Likely to Install Weatherproofing, All Heating Fuels

5.13.B Benefits Expected by Homeowners who Are Somewhat or Very Likely to Install Weatherproofing, Heating Fuel Electric

5.14.A Benefits Expected by Homeowners who Are Somewhat or Very Likely to Install Storm Windows, All Heating Fueis ...........

5.14.B Benefits Expected by Homeowners who Are Somewhat or Very Likely to Instail Storm Windows 
5.15.A Benefits Expected by Homeowners Who Are Somewhat or Very Likely to Install a Heat Pump/Furnace, All Heating Fuels ..... 5.20

5.15.B Benefits Expected by Homeowners who Are Somewhat or Very Likely to Install a Heat Pump/Furnace, Heating Fue?

Electric

5.16.A Benefits Expectec. by Homeowners Who Are Somewhat or Very Likely to Install an Automatic Setback Thermostat, All Heating Fuels

5.16. B Benefits Expected by Homeowners who Are Somewhat or Very Likely to Install an Automatic Setback Thermostat, Heating Fuel Electric

5.17. A Benefits Expected by Homeowners who Are Somewhat or Very Likely to Insulate Basement Fioor/Crawl Space, All Heating Fuels

5.17. B Benefits Expected by Homeowners who Are Somewhat or Very Likely to Insulate Basement Floor/Crawl Space, Heating

Fuel Electric

5.18.A Benefits Expected by Homeowners Who Are Somewhat or Very Likely to Insulate Outside Walls, All Heating Fuels

5.18.B Benefits Expected by Homeowners who Are Somewhat or Very Likely to Insuiate Outside Walis, Heating Fuel Electric

5.19.A Benefits Expected by Homeowners who Are Somewhat or Very Likely to Insulate Roofs or Attics, All Heating Fuels

5.19.B Benefits Expected by Homeowners Who Are Somewhat or Very Likely to Insulate Roofs or Attics, Heating Fuel Electric

5.20. A Benefits Expected by Homeowners who Are Somewhat or Very Likely to Install Solar Panels, All Heating Fuels

5.20.B Benefits Expected by Homeowners Who Are Somewhat or Very Likely to install Solar Panels, Heating Fuel Electric

5.21. A Benefits Expected by Honeowners who Are Somewhat or Very Likely to Install Storm Doors, All Heating Fuels ............ 5.26

5.21.B Benefits Expected by Homeowners Who Are Somewhat or Very Likely to Install Storm Doors, Heating Fuel Electric ........ 5.26

5.22. A Benefits Expected by Homeowners who Are Somewhat or Very Likely to Install Heat Pump Water Heaters, All Heating Fuels 
5.22.B Benefits Expected by Homeowners who Are Somewhat or Very Likely to Install Heat Pump Water Heaters, Heating

Fuel Electric .................................... 5.27

5.23.A Benefits Expected by Homeowners who Are Somewhat or Very Likely to Install wood Stoves, All Heating Fueis ........... 5.28

5.23.B Benefits Expected by Homeowners who Are Somewhat or Very Likely to Install Wood Stoves, Heating Fuel Electric ........ 5.28

5.24.A Benefits Expected by Homeowners who are Somewhat or Very Likely to Install Fireplace Inserts, All Heating Fuels ...... 5.29

5.24.B Benefits Expected by Homeowners who are Somewhat or Very Likely to Instail Fireplace Inserts, Heating Fuel Electric

9.1.A Reasons For Not Investing In Energy Conservation Measures, Heating Fuel Electric................................ 9.3

9.1.B Reasons For Not Investing In Energy Conservation Measures, A]l Heating Fuels 
TABLES

3.1. A Number of Energy Conservation Measures Homeowners Have Purchased, by Total Household Income ................... 3.2

3.1.B Number of Energy Conservation Measures Homeowners Have Purchased, by Total Household Income ................... 3.2

3.2. A Number of Energy Conservation Measures Homeowners Have Purchased, by the Type of Current Residence .............. 3.2

3.2.B Number of Energy Conservation Measures Homeowners Have

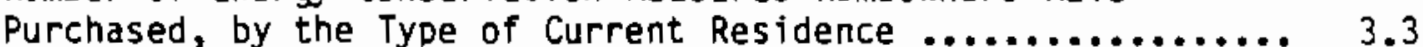

3.3. A Number of Energy Conservation Measures Homeowners Have Purchased, by Level of Education ....................... 3.4

3.3.8 Number of Energy Conservation Measures Homeowners Have Purchased, by Level of Education ...................... 3.4

3.4.A Number of Energy Conservation Measures Homeowners Have Purchased, by Unexpected Benefits Received ............... 3.5

3.4.B Number of Energy Conservation Measures Homeowners Have Purchased, by Unexpected Benefits Received .............. 3.6

3.5. A Number of Energy Conservation Measures Homeowners Have Purchased, by Reasons that Might Prevent Homeowners from Installing Additional Energy Conservation Measures .......... 3.6

3.5.B Number of Energy Conservation Measures Homeowners Have Purchased, by Reasons that Might Prevent Homeowners from Installing Additional Energy Conservation Measures

3.6. A Number of Energy Conservation Measures Homeowners Have Purchased, by Potential Sources of Funding for Future Investment in Energy Conservation Measures .................

3.6.B Number of Energy Conservation Measures Homeowners Have Purchased, by Potential Sources of Funding for Future Investment in Energy Conservation Measures .............. 3.8

3.7.A Number of Energy Conservation Measures Homeowners Have Purchased, by the Number of Energy Conservation Measures They Are Somewhat or Very Likeiy to Install in the Next

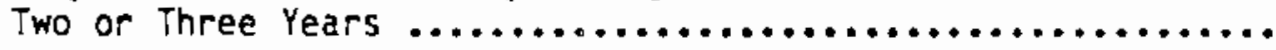


3.7.B Number of Energy Conservation Measures Homeowners Have Purchased, by the Number of Energy Conservation Measures They Are Somewhat or Very Likely to Install in the Next

Two or Three Years ...................................... 3.9

3.8. A Number of Energy Conservation measures Homeowners Have Purchased, by Average Monthly Heating Bill ................ 3.10

3.8.B Number of Energy Conservation Measures Homeowners Have Purchased, by Average Monthiy Heating Bill ................ 3.10

3.9.8 Number of Energy Conservation Measures Homeowners Have Purchased, by Homeowners' Attitudes Toward Their Own Energy Conservation Efforts

3.10.A Number of Energy Conservation Measures Homeowners Have Purchased, by Homeowners' Attitudes Towards Utilities offering Conservation Programs.

3.10.B Number of Energy Conservation Measures Homeowners Have Purchased, by Homeowners' Attitudes Towards Utilities

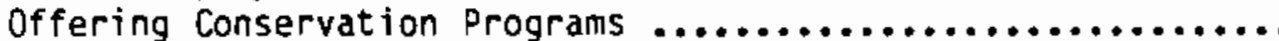

3.11. A Number of Energy Conservation Measures Homeowners Have Purchased, by Homeowners' Attitudes Towards Electricity Prices in the Northwest

3.11.B Number of Energy Conservation Measures Homeowners Have Purchased, by Homeowners' Attitudes Towards Electricity Prices in the Northwest

3.12. A Number of Energy Conservation Measures Homeowners Have Purchased, by Homeowners' Attitudes Toward Conserving Energy to Protect the Environment

3.12.B Number of Energy Conservation Measures Homeowners Have Purchased, by Homeowners' Attitudes Toward Conserving Energy to Protect the Environment

3.13. A Number of Energy Conservation Measures Homeowners Purchased, by Homeowners' Attitudes Towards Conserving Electricity for Future Generations.

3.13. B Number of Energy Conservation Measures Homeowners Purchased, by Homeowners' Attitudes Towards Conserving Electricity for Future Generations

4.1. A Homeowner Awareness of Utility Conservation Programs .........

4.1.8 Homeowner Awareness of UtiTity Conservation Programs ......... 
4.2. A Homeowner Perceptions of the Super Good Cents Program ....... 4.4

4.2.B Homeowner Perceptions of the Super Good Cents Program ....... 4.5

4.3. A Sources of Information About the Energy Consumption of New Appliances...................................... 4.5

4.3.B Sources of Information About the Energy Consumption of New Appliances..................................... 4.6

4.4.A Homeowner Perceptions of the Energy Guide Program .......... 4.9

4.4.B Homeowner Perceptions of the Energy Guide Program .......... 4.9

4.5.A Homeowner Perceptions of the Solar and Heat Pump Water Heater Program...................................... 4.10

4.5.B Homeowner Perceptions of the Solar and Heat Pump Water Heater Program..........................................

4.6.A Homeowner Perceptions of the Residential Weatherization Program ............................................

4.6.8 Homeowner Perceptions of the Residential Weatherization Program ............................................

4.7. A Specific Utility Energy Conservation Programs in which Homeowners Have Participated

4.7. B Specific Utility Energy Conservation Programs in Which Homeowners Have Participated

4.8. A Number of Energy Conservation Measures Installed by the Respondents Since Moving into Their Current Residence, Relative to Participation in a Utility Conservation Program

4.8.B Number of Energy Conservation Measures Installed by the Respondents Since Moving into Their Current Residence, Relative to Participation in a Utility Conservation

Program

4.9. A Number of Energy Conservation Measures Homeowners are Somewhat or Very Likely to Instail in the Next Two or Three Years, Relative to to Participation in a Utility Conservation Program

4.9.B Number of Energy Conservation Measures Homeowners are Somewhat or Very Likely to Install in the Next Two or Three Years, Relative to Participation in a Utility Conservation Program 
4.10. A Amount Homeowners Spent During the Past Two Years to

Reduce Energy Use in the Home, Relative to Participation

in a Utility Conservation Program ...................... 4.16

4.10.B Amount Homeowners Spent During the Past Two Years to

Reduce Energy Use in the Home, Relative to Participation

in a Utility Conservation Progran ....................... 4.16

5.1. A Installed Energy Conservation Measures, Benefits Received

Versus Not Received .................................... 5.30

5.1.B Installed Energy Conservation Measures, Benefits Received

Versus Not Received ................................... 5.30

5.2.A Benefits Expected by Homeowners Installing

Weatherproofing .................................... 5.31

5.2.B Benefits Expected by Homeowners Installing

Weatherproofing ................................. 5.31

5.3. A Benefits Expected by Homeowners Installing Storm Windows .... 5.31

5.3.8 Benefits Expected by Homeowners Installing Storm Windows .... 5.31

5.4.A Benefits Expected by Homeowners Installing Heat Pump

Furnace .......................................... 5.32

5.4.B Benefits Expected by Homeowners Installing Heat Pump

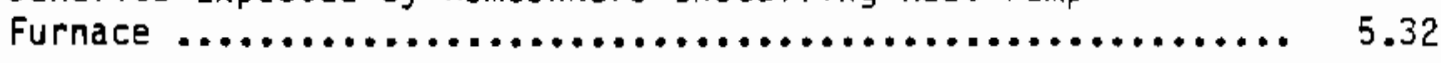

5.5.A Benefits Expected by Homeowners Installing Automatic or

Setback Thermostat .................................. 5.32

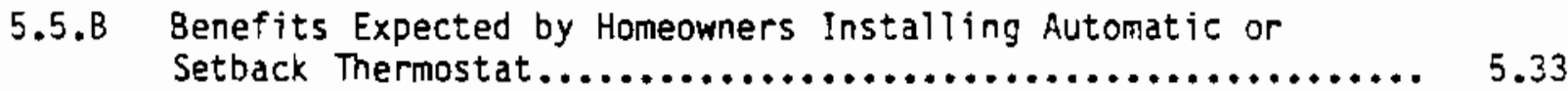

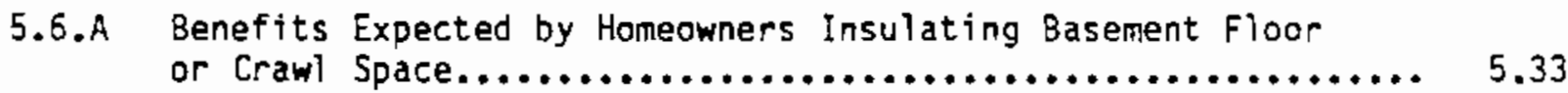

5.6.B Benefits Expected by Homeowners Insulating Basement Floor

or Crawt Space ................................... 5.33

5.7.A Benefits Expected by Homeowners Insulating Outside Wall $\ldots \ldots . \quad 5.34$

5.7.8 Benefits Expected by Homeowners Insulating Outside Wall $\ldots \ldots .5 .34$

5.8.A Benefits Expected by Homeowners Insulating Roof ........... 5.34

5.8.B Benefits Expected by Homeowners Insulating Roof ........... 5.35 
5.9. A Benefits Expected by Homeowners Installing Solar Panels ..... 5.35

5.10. A Benefits Expected by Homeowners Installing

Storm/Insulated Doors .............................. 5.36

5.10.B Benefits Expected by Homeowners Installing

Storm/Insulated Doors .............................. 5.36

5.11. A Benefits Expected by Homeowners installing Heat Pump

Water Heater ....................................... 5.36

5.11.B Benefits Expected by Homeowners Installing Heat Pump

Water Heater ......................................... 5.37

5.12. A Benefits Expected by Homeowners Installing

Wood Stove/Furnace ................................... 5.37

5.12.8 Benefits Expected by Homeowners Installing

Wood Stove/Furnace ................................... 5.37

5.13.A Benefits Expected by Homeowners Installing Fireplace

Inserts .......................................... 5.38

5.13.B Benefits Expected by Homeowners Installing Fireplace

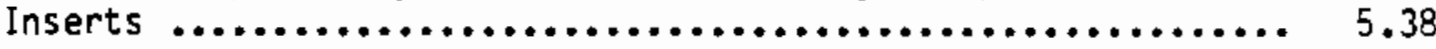

5.14.A Benefits Expected from Weatherproofing, According to

Date of Installation .............................. 5.38

5.14.8 Benefits Expected from Weatherproofing, According to

Date of Installation .................................. 5.39

5.15.A Benefits Expected from Storm Windows, According to

Date of Instaliation ................................ 5.39

5.15.B Benefits Expected from Storm Windows, According to

Date of Installation .................................. 5.39

5.16. A Benefits Expected from Heat Pump Furnace, According to

Date of Installation ................................. 5.40

5.16.B Benefits Expected from Heat Pump Furnace, According to

Date of Installation ................................ 5.40

5.17. A Benefits Expected from Automatic Setback Themostat, According to Date of Installation .................... 5.40

5.17.B Benefits Expected from Automatic Setback Thermostat, According to Date of Installation 
5.18. A Benefits Expected from Insulating Basement Floor or Crawl Space, According to Date of Installation ............. 5.41

5.18.B Benefits Expected from Insulating Basement Floor or Crawl Space, According to Date of Installation ............. 5.41

5.19. A Benefits Expected from Insulating Outside Walls, According to Date of Installation .................... 5.42

5.19.B Benefits Expected from Insulating Outside Walls, According to 0ate of Installation ..................... 5.42

5.20.A Benefits Expected from Insulating Roof or Attic, According to Date of Installation ...................... 5.42

5.20.B Benefits Expected from Insulating Roof or Attic, According to Date of Installation ...................... 5.43

5.21. A Benefits Expected from Solar Panels, According to Date of

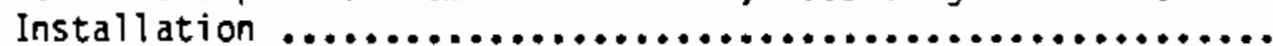

5.21. B Benefits Expected from Solar Panels, According to Date of

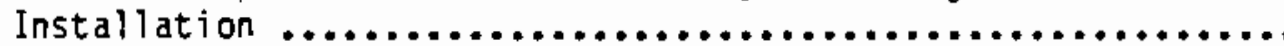

5.22. A Benefits Expected from Storm/Insulated Doors, According to Date of Installation

5.22.B Benefits Expected from Storm/Insulated Doors, According to Date of Installation

5.23.A Benefits Expected from Heat Pump Water Heater, According to Date of Installation

5.23.B Benefits Expected from Heat Pump Water Heater, According to Date of Installation

5.24. A Benefits Expected from Wood Stove/Furnace, According to Date of Installation

5.24.8 Benefits Expected from Wood Stove/Furnace, According to

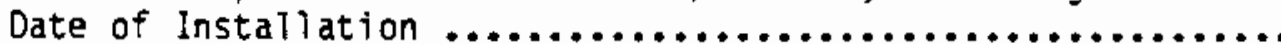

5.25. A Benefits Expected from Fireplace Insert, According to Date of Installation ...................................

5.25.B Benefits Expected from Fireplace Insert, According to Date of Installation

6.1. A Number of Energy Conservation Measures Installed by Current Homeowners, by Length of Time at Current 
6.1.B Number of Energy Conservation Measures Installed by Current Homeowners, by Length of Time at Current

Residence

6.2

6.2. A Number of Energy Conservation Measures Installed by Current Occupants, by Number of Occupants Including the Homeowner

6.2.B Number of Energy Conservation Measures Installed by Current Occupants, by Number of Occupants Including the Homeowner

6.3.A Number of Energy Conservation Measures Installed by Current Occupants, by Occupation of the Homeowner

6.3.B Number of Energy Conservation Measures Installed by Current Occupants, by Occupation of the Homeowner

6.4.A Number of Energy Conservation Measures Installed by Current Occupants, by Occupation of the Second Householder

6.4.B Number of Energy Conservation Measures Installed by Current Occupants, by Occupation of the Second Householder

6.5.A Number of Energy Conservation Measures Installed by Current Occupant, by Education Level of the Household

6.5.B Number of Energy Conservation Measures Installed by Current Occupant, by Education Level of the Household ........ 6.8

6.6. A Number of Energy Conservation Measures installed by Current Occupants, by Total Household Income ............... 5.9

6.6.B Number of Energy Conservation Measures Installed by Current Occupants, by Total Household Income

6.7. A Number of Energy Conservation Measures Installed by Current Occupants, by Geographic Location ................. 6.10

6.7.B Number of Energy Conservation Measures Instailed by Current Occupants, by Geographic Location

6.8.A Number of Energy Conservation Measures Homeowners Are Somewhat or Very Likely to Install in the Next Two to Three Years, by Length of Time at Current Residence

6.8.B Number of Energy Conservation Measures Homeowners Are Somewhat or Very Likely to Install in the Next Two to Three Years, by Length of Time at Current Residence 
6.9.A Number of Energy Conservation Measures Homeowners Are Somewhat or Very Likely to Install in the Next Two or Three Years, by Number of Occupants in the Household

6.9.B Number of Energy Conservation Measures Homeowners Are Somewhat or Very Likely to Install in the Next Two or Three Years, by Number of Occupants in the Househoid

6.10.A Number of Energy Conservation Measure Homeowners Are Somewhat or Very Likely to Install in the Next Two to Three Years, by Level of Education

6.10.B Number of Energy Conservation Measures Homeowners Are Somewhat or Very Likely to Install in the Next Two to Three Years, by Level of Education

6.11. A Number of Energy Conservation Measures Homeowners Are Somewhat or Very Likely to Install in the Next Two to Three Years, by Total Household Income

6.11.B Number of Energy Conservation Measuers Homeowners Are Somewhat or Very Likely to Install in the Next Two to Three Years, by Total Household Income

6.12. A Number of Energy Conservation Measures Homeowners Are Somewhat or Very Likely to Install in the Next Two to Three Years, by Geographic Location

6.12.B Number of Energy Conservation measures Homeowners Are Somewhat or Very Likely to Install in the Next Two to Three Years, by Geographic Location

7.1.A Total Household Income, by Life Cycle Segments ........... 7.3

7.1.B Total Household Income, by Life Cycle Segments ............ 7.4

7.2.A Length of Time Respondents Have Been at Their Current Residence by Life Cycle Segments ...................... 7.4

7.2.B Length of Time Respondents Have Been at Their Current Residence by Life Cycle Segments ....................... 7.5

7.3.A Type of Residence, by Life Cycle Segments .............. 7.6

7.3.B Type of Residence, by $L{ }^{s}$ e Cycle Segments ............... 7.6

7.4. A Ways to Reduce Energy Use at Home, by Life Cycle Segments ... 7.7

7.4.8 Ways to Reduce Energy Use at Home, by Life Cycle Segments .... 7.8 
7.5.A Number of People in the Household, by Life Cycle Segments .... 7.9

7.5.8 Number of People in the Househoid, by Life Cycle Segments .... 7.9

7.6. A Number of Energy Conservation Measures Installed, by Life Cycle Segments .................................. 7.10

7.6.B Number of Energy Conservation Measures Installed, by Life Cycle Segments

7.7. A Number of Energy Conservation Measures Homeowners are Somewhat or Very Likely to Install in the Next Two to Three Years, by Life Cycle Segments

7.7.8 Number of Energy Conservation Measures Homeowners are Somewhat or Very Likeiy to Install in the Next Two to Three Years, by Life Cycle Segments

7.8.A Total Household Income, By Cynicism Factor ............... 7.15

7.8.8 Total Household Income, by Cynicism Factor .............. 7.15

7.9. A Length of Time Homeowners Have Been at the Current Residence, by Cynicism Factor

7.9.8 Length of Time Homeowners Have Been at the Current Residence, by Cynicism Factor ...................... 7.16

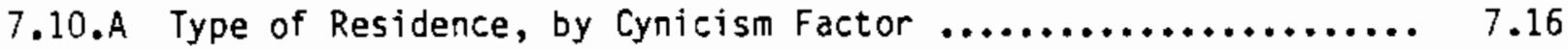

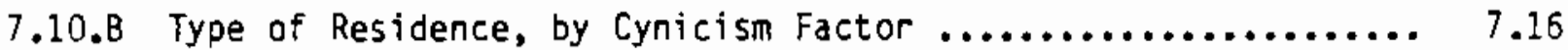

7.11. A Ways to Reduce Energy Use at Home, by Cynicism Factor ...... 7.17

7.I1.B Ways to Reduce Energy Use at Home, by Cynicism Factor ...... 7.17

7.12.A Total Household Incone, by Altruism Factor .............. 7.18

7.12.B Total Household Income, by Altruism Factor ............... 7.18

7.13.A Length of Time Homeowners Have Been at Their Current Residence, by Altruism Factor ...................... 7.18

7.13.B Length of Time Homeowners Have Been at Their Current Residence, by Aitruism Factor ......................... 7.19

7.14.A Type of Residence, by Altruism Factor ................... 7.19

7.14.B Type of Residence, by Altruism Factor .................. 7.19 
7.15.A Ways to Reduce Energy Use at Home, by Altruism Factor ...... 7.20

7.15.B Ways to Reduce Energy Use at Home, by Altruism Factor ...... 7.20

7.16. A Number of Energy Conservation Measures Installed, by Cynicism Factor .....................................

7.16.B Number of Energy Conservation Measures Installed, by

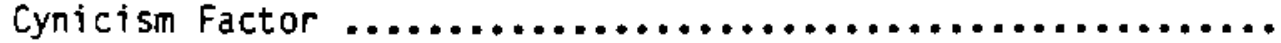

7.17. A Number of Energy Conservation Measures Homeowners are Somewhat or Very Likely to Install in the Next Two to Three Years, by Cynicism Factor

7.17.B Number of Energy Conservation Measures Homeowners are Somewhat or Very Likely to Install in the Next Two to Three Years, by Cynicism Factor

7.18. A Number of Energy Conservation Measures Installed, by Altruism Factor

7.18. B Number of Energy Conservation Measures Installed, by Altruism Factor

7.19. A Number of Energy Conservation Measures Homeowners are Somewhat or Very Likely to Install in the Next Two to

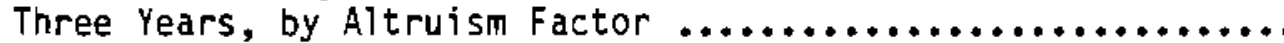

7.19.B Number of Energy Conservation Measures Homeowners are Somewhat or Very Likely to Install in the Next Two to

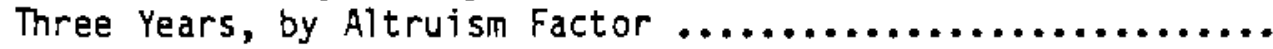

8.1. A Amount Homeowners Spent During the Past Two Years to Reduce Energy Use in Their Home, by Level of Concern for Energy Use

8.1.B Amount Homeowners Spent During the Past Two Years to Reduce Energy Use in Their Home, by Level of Concern for Energy Use

8.2. A Amount Homeowners Spent During the Past Two Years to Reduce Energy Use in Their Home, by Level of Concern for the Cost of Energy

8.2. B Amount Homeowners Spent During the Past Two Years to Reduce Energy Use in Their Home, by Level of Concern for the cost of Energy

8.3.A Amount Homeowners Spent During the Past Two Years to Reduce Energy Use in Their Home, by Level of Concern for Energy Conservation 
8.3.B Amount Homeowners Spent During the Past Two Years to Reduce Energy Use in Their Home, by Level of Concern for Energy Conservation

8.4.A Amount Homeowners Spent During the Past Two Years to Reduce Energy Use in Their Home, by Attitude Toward

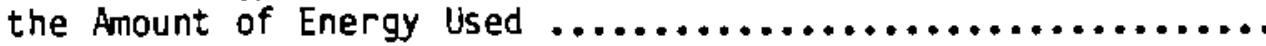

8.4.B Amount Homeowners Spent During the Past Two Years to Reduce Energy Use in Their Home, by Attitude Toward

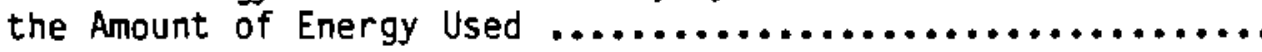

8.5. A Amount Homeowners Spent During the Past Two Years to Reduce Energy Use in Their Home, by Attitude Toward the Anount of Electricity Used.

8.5.B Amount Homeowners Spent During the Past Two Years to Reduce Energy Use in Their Home, by Attitude Toward the Amount of Electricity Used ......................... 8.8

8.6.A Amount Homeowners Spent During the Past Two Years to Reduce Energy Use in Their Home, by Attitude Toward Ability to Conserve Energy ............................. 8.9

8.6.B Amount Homeowners Spent During the Past Two Years to Reduce Energy Use in Their Home, by Attitude Toward Ability to Conserve Energy ...............................

8.7. A Amount Homeowners Spent During the Past Two Years to Reduce Energy Use in Their Home, by Attitude Toward Consulting Consumer Reports

8.7.B Amount Homeowners Spent During the Past Two Years to Reduce Energy Use in Their Home, by Attitude Toward Consulting Consumer Reports

8.8.A Amount Homeowners Spent During the Past Two Years to Reduce Energy Use in Their Home, by Attitude Toward utilities of fering Conservation Programs

8.8.B Amount Homeowners Spent During the Past Two Years to Reduce Energy Use in Their Home, by Attitude Toward

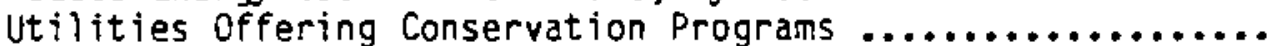

8.9.A Amount Homeowners Spent During the Past Two Years to Reduce Energy Use in Their Home, by Attitude Toward Improving the Efficiency of Their Home

8.9.B. Amount Homeowners Spent During the Past Two Years to Reduce Energy Use in Their Home, by Attitude Toward Improving the Efficiency of Their Home 
8.10. A Amount Homeowners Spent During the Past Two Years to

Reduce Energy Use in Their Home, by Attitude Toward

Electricity Prices in the Northwest

8.10.B Amount Homeowners Spent During the Past Two Years to

Reduce Energy Use in Their Home, by Attitude Toward

Electricity Prices in the Northwest

8.11. A Amount Homeowners Spent During the Past Two Years to

Reduce Energy Use in Their Home, by Attitude Toward

Electricity Rate Changes Made by the Utility

8.11.B Amount Homeowners Spent During the Past Two Years to

Reduce Energy Use in Their Home, by Attitude Toward

Electricity Rate Changes Made by the Utility ...............

8.12. A Amount Homeowners Spent During the Past Two Years to

Reduce Energy Use in Their Home, by Attitude Toward

Power Surplus in the Northwest

8.12.B Amount Homeowners Spent During the Past Two Years to

Reduce Energy Use in Their Home, by Attitude Toward

Power Surplus in the Northwest

8.13.A Amount Homeowners Spent During the Past Two Years to

Reduce Energy Use in Their Home, by Attitude Toward

the Effect of Conservation Efforts

8.13.B Amount Homeowners Spent During the Past Two Years to

Reduce Energy Use in Their Home, by Attitude Toward

the Effect of Conservation Efforts

8.14. A Amount Homeowners Spent During the Past Two Years to

Reduce Energy Use in Their Home, by Attitude Toward

Protecting the Environment

8.14.B Amount Homeowners Spent During the Past Two Years to

Reduce Energy Use in Their Home, by Attitude Toward

Protecting the Environment

8.15. A Amount Homeowners Spent During the Past Two Years to

Reduce Energy Use in Their Home, by Attitude Toward

Conserving Electricity for Future Generations

8.15.B Amount Homeowners Spent During the Past Two Years to

Reduce Energy Use in Their Home, by Attitude Toward

Conserving Electricity for Future Cenerations ...............

8.16. A Amount Homeowners Spent During the Past Two Years to

Reduce Energy Use in Their Home, by Attitude Toward

Conserving Electricity to Save Money 
8.16.8 Amount Homeowners Spent During the Past Two Years to Reduce Energy Use in Their Home, by Attitude Toward

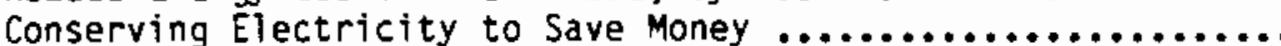

8.17. A Amount Homeowners Spent During the Past Two Years to Reduce Energy Use in Their Home, by Attitude Toward

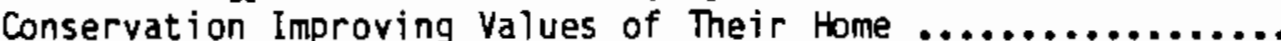

8.17.B Amount Homeowners Spent During the Past Two Years to Reduce Energy use in Their Home, by Attitude Toward Conservation Improving Values of Their Home .................

8.18. A Amount Homeowners Spent During the Past Two Years to Reduce Energy Use in Their Home, by Attitude Toward Increasing Comfort of Their Home

8.18.B Amount Homeowners Spent During the Past Two Years to Reduce Energy Use in Their Home, by Attitude Toward Increasing Comfort of Their Home

9.1.A Reason Not to Invest in Energy Conservation Measure, by

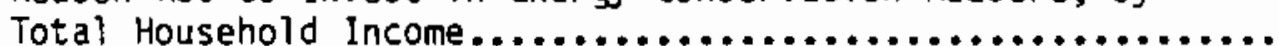

9.1.B Reason Not to Invest in Energy Conservation Measures, by Total Household Incone

9.2. A Reason Not to Invest in Energy Conservation Measures, by Length of Time Homeowners Have Been at their Residence........ 9.5

9.2.B Reason Not to Invest in Energy Conservation Measures, by Length of Time Homeowners have Been at Their Residence.........

9.3.A Reason Not to Invest In Energy Conservation Measures, by Type of Residence....................................

9.3.B Reason Not to Invest in Energy Conservation Measures, by Type of Residence.....................................

9.4. A Reason Not to Invest in Energy Conservation Measures, by Amount Spent by Homeowners During the Past Two Years to Reduce Energy Use.

9.4.B Reason Not to Invest in Energy Conservation Measures Amount Spent by Homeowners During the Past Two Years to Reduce Energy Use. 


\subsection{INTRODUCTION}

This report presents information on consumer attitudes toward conservation, past and intended conservation behaviors, and utility-sponsored conservation program participation levels. The information was collected by means of random telephone surveys of households in Idaho, Oregon, Washington, and Western Montana. Pacific Northwest Laboratory (PNL) (a) conducted analyses of the survey results for the Bonneville Power Administration (BPA) to obtain a better understanding of consumer attitudes and behaviors and to facilitate conservation program planning, design, and marketing.

\subsection{BACKGROUNO}

During 1983-84, PNL conducted the Phase I study of consumer energy conservation attitudes for the BPA. This study was part of an overall project designed to assess the marketing environment for BPA's energy conservation programs and activities. It was the first comprehensive regional study of its kind and established a baseline for future tracking.

In the baseline study, a telephone survey of 2000 residents of the Northwest was conducted. (b) The sample was drawn to represent a cross-section of consumers in the Northwest and was composed of 500 respondents from each of four geographic divisions: Western Washington; Western Oregon; Eastern Oregon and Southern Idaho; Eastern Washington, Northern Idaho, and Western Montana. The respondents were adult heads of households. Only one respondent per household was interviewed. Eighty percent of the interviews were conducted during evening and weekend hours between October 30 and November 13, 1983. Seventyfive percent of the interviews lasted approximately 20 minutes. Interviews with the remaining respondents lasted approximately 50 minutes because of additional questions relating specifically to heat pums and solar water heaters.

The respondents were asked questions regarding their attitudes, perceptions, and awareness of energy conservation; their conservation actions and

\footnotetext{
(a) Operated for the Oepartment of Energy by Battelle Menorial Institute under contract OE-ACO6-76RLO 1930.

(b) The survey was conducted by RMH Research Inc. of River Edge, New Jersey.
} 
measures to date; their methods of financing past conservation investments; their perceptions of energy institutions; their behaviors with respect to public communication media such as newspapers, radio and television; and their willingness to invest in energy conservation and its relationship to perceived rates of returns.

The results of the baseline study (RMH Research, InC. 1984a) were published and compared with results from other studies (Fang 1985). A companion survey on the marketing environment for solar and heat pump water heaters was also conducted (RMH Research, 1984b).

In July 1985, PNL undertook Phase II of the project to analyze the marketing environment for BPA conservation activities with the following three objectives:

1. to track changes in consumer attitudes, interests and opinions between 1983 and 1985

2. to identify more refined segments of the residential conservation market in terms of attitudes, interests, and opinions

3. to test hypotheses concerning consumer conservation actions and investment behaviors.

To achieve these objectives, a second survey of Northwest consumers was conducted in late 1985. This report provides the data, information, and analyses to achieve Objective 2 and part of objective 3 . Specifically the hypotheses being tested in this report include:

1. Repeat investors in energy conservation measures (ECMs) will need a greater incentive to invest in additional ECMs than will other groups of consumers.

2. Consumer behavior and intentions toward conservation will not vary by participation in utility sponsored conservation programs.

3. Consumer behavior and intentions toward conservation will not vary by expected benefits.

4. Consumer behavior and intentions toward conservation will not vary by demographically defined groups. 
5. Consumer behavior and intentions toward conservation will not vary by value, attitude and lifestyle (VALs) questions or family life-cycle defined segments.

6. The amount of money spent on ECMs will not vary by homeowners' perceptions of conservation.

7. The primary barriers to conservation investment are noneconomic.

\subsection{SURVEY AND SAMPLE DESCRIPTIONS}

In the 1985 survey, 1058 teiephone interviews were completed. The sample was drawn from Idaho, Oregon, Washington and Western Montana, with nearly equal numbers of respondents from each of the same four geographical divisions as in the 1983 sample. Interviews were conducted from October 15 through November 8, 1985. Calls were made from 4 p.m. to $9 \mathrm{p.m}$. on weekdays and from 10:30 a.m. to 7 p.m. on Saturdays and Sundays. Each interview took between 35 and 45 minutes to complete. The refusal rate was $13 \%$ and the termination rate was $10 \%$ (a)

The data presented in this report have been weighted to approximate population values in the BPA service area. First, the populations of counties within each of the four geographic divisions in the BPA service area were determined and summed. This yielded a total population count for each geographic division. The total counts for the four geographic divisions were then sumed to arrive at a total population for the BPA service area. The populations of each division were then expressed as a percentage of the total population of the region. The weights were derived by comparing the sample observations fram the geographic divisions with their respective divisional populations. Ail population values were approximated by using the 1980 Census data. (b) Table 1.1 presents the details of the weights by geograpicic division.

(a) For detailed description of sampling design, survey procedure, and survey instrument, see Columbia Research Center, 1985 Marketing Environment for BPA Conservation Activities: Phase II, Draft report submitted to Pacific Northwest Laboratory, December 6, 1985, Portl and, Oregon.

(b) Total number of households in the Pacific Northwest for 1980 is 3,022,490. 
TABLE 1.1. Weights by Geographic Division

\begin{tabular}{|c|c|c|c|c|c|}
\hline $\begin{array}{c}\text { Geographic } \\
\text { Division }\end{array}$ & $\begin{array}{c}\text { Relative } \\
\text { Weight }\end{array}$ & $\begin{array}{l}\text { Percent } \\
\text { of Total } \\
\text { Households } \\
\end{array}$ & $\begin{array}{l}\text { Households } \\
\text { in Division } \\
\end{array}$ & $\begin{array}{l}\text { Households } \\
\text { in Sample } \\
\end{array}$ & $\begin{array}{l}\text { Weight for } \\
\text { Division } \\
\end{array}$ \\
\hline W. Washington & 1.58 & 39.50 & $1,193,884$ & 258 & $4,627.5$ \\
\hline W. Oregon & 1.12 & 20.80 & 846,297 & 270 & $3,134.4$ \\
\hline $\begin{array}{l}\text { E. Washington, } \\
\text { N. Idaho, \& } \\
\text { W. Montana }\end{array}$ & 0.73 & 18.25 & 551,604 & 274 & $2,013.2$ \\
\hline $\begin{array}{l}\text { E. Oregon \& } \\
\text { S. Idaho }\end{array}$ & 0.57 & 14.25 & 430,705 & 256 & $1,682.4$ \\
\hline Total & 4.00 & 100.00 & $3,022,490$ & 1,058 & $=-$ \\
\hline
\end{tabular}

The survey inciuded responses from both homeowners and renters. However, since several of the survey questions did not apply to renters and because homeowners are much more likely to invest in ECMs, results were tabulated for homeowners only. In addition to providing results on ali homeowners regardless of the heating fuel used in their residence, the report also presents the same findings for homeowners who use electricity as their primary or secondary heating fuel. This was done because the BPA's primary interest is electricity, and their programs are designed for consumers of electricity.

\subsection{REPORT STRUCTURE}

Each of the following chapters will address a specific hypothesis. Within each chapter, relevant segmentation schemes will be addressed; and other variables that are relevant to the hypothesis will be discussed. Chapter 2.0 provides an overview of the findings derived from the analyses conducted in this study and discusses some of the implications. Chapter 3.0 looks at the issue of whether repeat purchasers of ECMs need more of an incentive to invest further than do other groups of consumers. Chapter 4.0 explores the specific utility programs in which homeowners have participated. Chapter 5.0 reviews the benefits which homeowners expected from past and future investments in ECMs. Chapter 6.0 reviews the demographic segments and how they relate to consumer behavior and intentions toward conservation. Chapter 7.0 presents 
segmentation schemes based on the homeowners' responses to several value, attitude and lifestyle questions and on family life-cycle defined segments. These segmentation schemes are then used to explain actual and intended conservation behavior. Chapter 8.0 discusses homeowners' perceptions of conservation and how these perceptions may have affected the amount of money they have spent during the past two years to reduce energy use in their residences. Chapter 9.0 reviews the homeowners' actual or perceived barriers that prevent conservation investment. 
.

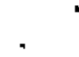




\subsection{FINDINGS}

Chapters 3 through 9 present detailed analyses and discussion of data and information with respect to consumer behavior and intentions toward energy conservation and how they are related to past experience, utility program participation, demographics of the households, attitudes toward conservation and perceived barriers to conservation investment. This chapter provides a summary of the findings and conclusions.

\subsection{PAST CONSERVATION BEHAVIOR ANO THE NEED FOR INCENTIVES TO INVEST FURTHER}

Homeowners who have purchased and/or invested in more than one ECM appear from the analyses to have high incomes, live in single-detached homes, report receiving unexpected monetary benefits from their conservation investments, and report utility and bank loans as potential funding sources for conservation investments. The above characteristics are representative for repeat purchasers more frequently than for homeowners who are nonpurchasers or single measure purchasers. The results do not appear to differ between the entire sample and households using electricity.

The results aiso showed that repeat purchasers are more able financially to invest and may have more interest in energy conservation because they more frequently live in single-detached family homes. Many conservation measures are designed for single-detached family homes as opposed to mobile homes. Moreover, since repeat purchasers more frequently reported monetary benefits as unexpected, it would appear that this group may be investing in conservation for reasons such as increased comfort. From these results, repeat purchasers of ECMs do not appear to need incentives to invest in additional energy conservation. Therefore, the hypothesis of repeat purchasers needing more of an incentive to invest in ECMs cannot be supported.

\subsection{PARTICIPATION IN UTILITY SPONSOREO CONSERVATION PROGRAMS}

Over $50 \%$ of the homeowners surveyed stated that they were aware of at least one utility-sponsored utility program. However, when asked to name a specific program, less than $10 \%$ of these respondents were able to mention a 
specific program. Residential Weatherization was the program most frequently mentioned by respondents. When asked if they had participated in any utilitysponsored programs, approximately $20 \%$ of the homeowners reported that they had. Again, the most frequently mentioned program was Residential Weatherization.

Over 35\% of homeowners who had participated in at least one utilitysponsored program had installed five or more conservation measures in their homes. However, $30 \%$ of those who had not participated in a utifity-sponsored program had also installed five or more conservation measures. Comparing homeowners who had participated in a utility-sponsored program with those who had not, those homeowners who had participated indicated a greater likelihood of investing in three or more measures during the next two to three years. The results indicate that consumer behavior and intentions toward conservation investment vary by participation in a utility-sponsored conservation program. These results in turn support rejecting the hypothesis that behavior and intention would not vary by participation in such a program.

\subsection{EXPECTED BENEFITS OF ENERGY CONSERVATION MEASURES}

Households that had previousiy installed ECMs had expected monetary as well as comfort benefits. These expectations changed when respondents were asked about future ECM installation in the next two to three years. For more than three-fourths of the ECMs, respondents reported that they expect to receive primarily monetary benefits. The results seem to give some support to rejecting the hypothesis that consumer behavior and intentions do not vary by the benefits expected from different ECMs.

Information such as this is very useful when designing marketing programs. If consumers expect monetary benefits and if they do not receive direct financial benefit, then marketing program 3 must be sensitive to this information. Marketing programs may decide to advertise that monetary benefits could vary and/or monetary benefits may not be the primary benefit for a certain conservation measure. 


\subsection{DEMOGRAPHIC INFLUENCES ON CONSERVATION INVESTMENT}

The following trends were observed when analyzing several demographic variables and how they related to investing in energy conservation measures in the past:

- As length of time in a home increases, so does the number of ECMS installed. One exception is that, as indicated by the data, if 8+ ECMs are not installed within one year of initially occupying the home, it is not likely that this high level of $8+$ ECMs will be reached later.

- As the number of people in the household increases, so does the number of ECMs instalied. The exception is that 4- and 5-person households are not as likely to have installed $8+$ ECMs as are the 2and 3-person households.

- Occupational groups exhibited a large variability within each group regarding EOH installation. However, no single group was highly active or inactive.

- Second-householder occupation groups exhibited a large variability within each group regarding ECM installation, and no single group was highiy active or inactive.

- As Tevel of education increases, so does the number of ECMs installed.

- As level of household income increases, so does the number of ECMs installed.

- The Southwest quadrant has been most active followed by the Northeast, the Northwest, and last, the Southeast.

In regards to the likelihood of future ECM installation, the same demographic variabies were analyzed to assess their influence. The major findings are as follows:

- As length of time in a home increases, the likelihood of future ECM installation decreases. 
- As number of people in the household increases, so does the likelihood of future ECM installation.

- As level of education increases, so does the likelihood of future ECM installation.

- The Northwest and Southeast quadrants are the most likely to install ECMs in the future.

The hypothesis tested in this chapter states that consumer behavior and intentions toward installation of energy conservation measures will not vary by demographically defined groups. The results indicate that certain demographic variables do in fact have an effect both on past behavior and future plans to install ECMs. Of the seven denographic variables used to test the hypothesis with regard to past behavior, only five had some degree of influence on the number of energy conservation installed. These five include total household income, education level, number of people in the househoid, length of occupancy in the current residence, and geographic location.

In terms of the residents future intentions regarding conservation investment, the same five demographic variables appear to have the same effect oniy stronger on whether they will invest in the future. From these results it appears that investment in energy conservation measures is most likely to occur during the first few years of occupancy in a residence; larger households are more likely to install ECMs; both education and income have a positive affect on likelihood of ECM installation; and homeowners in the Northwest and Southeast had been least active in the past but report greater likelihood of ECM investment in the future.

\subsection{INFLUENCE OF ATTITUDES AND FAMILY LIFE CYCLE SEGMENT ON CONSERVATION INVESTMENT}

The results of the analyses indicate that consumer behavior and intentions toward conservation do vary by the family life cycie a househoid currently finds itself. The two life cycle segments that appear most receptive and capable of installing ECMs are the Young Adults-Childless and Early Parenthood. These segments have moderately high incomes, shorter length of stay at current. residences compared to other segments, fewer ECMs installed, and the greatest 
likelihood of installing three or more ECMs in the future. Marketing programs should be geared towards the demographic data available on these two segments. Both segments are composed of young adults, and the Early Parenthood group also has children. Advertising ECMs may be more successful if the advertising depicts families similar to the Young Adult-Childless and Early Parenthood segments.

A statistical procedure called Factor Analysis was used to analyze the value, attitude and lifestyle statements in the Phase II survey. The analysis indicated that there were two factors which measured the leveis of cynicism and altruism that homeowners may have felt toward several of the statements. The results seem to indicate that consumer behavior and intentions toward conservation do vary by the respondents responses to value, attitude and lifestyle statements.

In terms of the cynicism factor, the respondents who scored high on the factor may be more inclined to invest in ECMs than those who scored low. In fact, those with high scores more frequently indicated that they would prefer to spend money on ECMs than did those who scored low. This high cynicism group had installed fewer ECMs in the past and therefore may have more reason to invest. However, this group tends to have lower incomes than those who scored low. There was not much difference between the two groups in terms of the number of ECMs they were likely to install in the next two to three years.

Respondents who scored low on the altruism factor may be more inclined to invest in ECMs that those who scored high. This low group had higher incomes and had installed fewer ECMs than those who scored high on the altruism factor. This group also indicated that they were more inclined to installed three or more ECMs in the next two to three years.

The results of the factor analys is should be interpreted with caution because the two factors account for only about $55 \%$ of the variance. In addition, there are wording probiems in several of the statements. In future analyses, closer scrutiny of the statements with wording problems may result in omitting then from the analyses. Control of additional variables may aiso increase the percent of variance accounted for. 


\subsection{PERCEPTUAL INFLUENCES ON THE AMOUNT OF MONEY SPENT FOR ENERGY}

CONSERVATION MEASURES

Respondents were asked about their level of concern for energy use in the home, cost of energy and energy conservation. The results showed that in general, as concern for an issue increased so did the level of conservation spending. Of the three issues, homeowners expressed greatest concern over the cost of energy.

The respondents were also asked to respond to several attitudinal statements. It became apparent that those who spent nothing were more likely to give a negative response to the statements while those who spent something on energy conservation tended to give more positive responses.

The hypothesis which was tested in this chapter states, that the amount of money spent on ECMs will not vary by homeowners' perceptions of conservation. The findings indicate that the hypothesis should be rejected.

\subsection{PERCEIVED BARRIERS TO ENERGY CONSERVATION INVESTMENT}

It was hypothesized that the primary barriers to homeowner investment in ECMs are non-economic. The results of the anajyses overwhelmingly show that, according to the reports from respondents, the primary barriers to investment in ECMs are economic. Nearly $60 \%$ of the homeowners stated that cost was the primary barrier to conservation investment. The next most frequent reason given for not investing was that homeowners feit no need to invest. This may be true for some of the residences. However, a relatively large segment of these homeowners may not be aware that certain ECMs can reduce energy use and still be cost effective.

Homeowners who had lived at their current residences three year or longer stated more often that they did not need to install any conservation measures as opposed to homeowners living at their current residences less than three years. These results may indicate that if homeowners are going to invest in ECMs, they may be more inclined to do so during the first couple of years in their residences. 
Homeowners reporting cost as a barrier may be unaware of utility sponsored conservation programs or other types of loan programs that could aid in reducing costs and/or make investing in ECMs financially appealing. An important area for further study is the question of why $30 \%$ of homeowners feel that there is no need to invest in ECMs. 
$+$

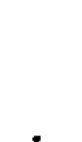




\subsection{PURCHASE BEHAVIOR OF HOMEOWNERS}

An overall objective of this study is to better understand what motivates consumers to invest in ECMs for their homes and/or to participate in energy conservation programs. As part of this objective, it is beneficial to investigate the differences between consumer groups in terms of their levels of past energy conservation investment: homeowners who have made repeat investments in or purchases of energy conservation measures (repeat purchasers), those who have not invested at all (nonpurchasers), and those who have made only one purchase in the past (single-measure purchasers). One hypothes is is that repeat purchasers will need more of an incentive to invest further in energy conservation measures than will other consumer groups. Chapter 2 will attempt to address this hypothesis by comparing repeat purchasers with single-measure purchasers and, where appropriate, nonpurchasers. By assessing unexpected benefits, reasons not to invest, potential sources of funding, likelihood of future conservation investment, demographics, and attitude responses, it should be possible to provide an answer to the hypothesis.

\subsection{DEMOGRAPHIC FACTORS THAT INFLUENCE PURCHASE BEHAVIOR}

The level of past energy conservation investment was related positively to the homeowner's total household income. (See Table 3.1.A.) Over $40 \%$ of the repeat purchasers had a total household income of more than $\$ 30,000$, while jess than $35 \%$ of the non- and single-measure purchasers had incomes over $\$ 30,000$. Income level may help to explain why repeat purchasers, more than other consumers, have been abie to invest in ECMs. A similar relationship between total household income and level of past energy conservation investment appears to exist for homeowners who use electricity as a heating fuel (see Table 3.1.B). Whether or not there are additional incentives, repeat purchasers are simply better able financially to invest in ECMs.

The distribution of type of residence by number of conservation measures purchased is displayed in Table 3.2.A. Over $90 \%$ of the repeat purchasers live in single-family detached homes, while $84 \%$ of the single-measure purchasers and $74 \%$ of the nonpurchasers lived in this type of residence. On the other hand, 
TABLE 3.1.A. Number of Energy Conservation Measures Homeowners Have Purchased, by Total Household Income

\begin{tabular}{|c|c|c|c|}
\hline \multirow[b]{2}{*}{$\begin{array}{l}\text { Total } \\
\text { Household Income }\end{array}$} & \multicolumn{3}{|c|}{$\begin{array}{l}\text { Number of Energy } \\
\text { Conservation Measures } \\
\text { Homeowners (in 1000s) } \\
\text { Al 1 Heating Fuels }(n=1977)\end{array}$} \\
\hline & $\begin{array}{l}\text { None } \\
(n=331)\end{array}$ & $\begin{array}{c}\text { One } \\
(n=333) \\
\end{array}$ & $\begin{array}{l}\text { Two or More } \\
(n=1313)\end{array}$ \\
\hline Less than $\$ 16,000$ & $23 \%$ & $25 \%$ & $22 \%$ \\
\hline$\$ 16,000$ to $\$ 30,000$ & 45 & 41 & 34 \\
\hline More than $\$ 30,000$ & 32 & 34 & 44 \\
\hline
\end{tabular}

TABLE 3.1.B. Number of Energy Conservation Measures Homeowners Have Purchased, by Total Household Income

\begin{tabular}{|c|c|c|c|}
\hline \multirow[b]{2}{*}{$\begin{array}{l}\text { Total } \\
\text { Household Income }\end{array}$} & \multicolumn{3}{|c|}{$\begin{array}{l}\text { Number of Energy } \\
\text { Conservation Measures } \\
\text { Homeowners (in 1000s) } \\
\text { Heating Fuel Electric (n=1161) }\end{array}$} \\
\hline & $\begin{array}{c}\text { None } \\
(n=192)\end{array}$ & $\begin{array}{c}\text { One } \\
(n=214)\end{array}$ & $\begin{array}{c}\text { Two or More } \\
(n=754)\end{array}$ \\
\hline Less than $\$ 16,000$ & $19 \%$ & $29 \%$ & $25 \%$ \\
\hline$\$ 16,000$ to $\$ 30,000$ & 50 & 44 & 32 \\
\hline More than $\$ 30,000$ & 31 & 27 & 43 \\
\hline
\end{tabular}

TABLE 3.2.A. Number of Energy Conservation Measures Homeowners Have Purchased, by the Type of Current Residence

\begin{tabular}{|c|c|c|c|}
\hline \multirow[b]{2}{*}{ Type of Residence } & \multicolumn{3}{|c|}{$\begin{array}{l}\text { Number of Energy } \\
\text { Conservation Measures } \\
\text { Homeowners (in 1000s) } \\
\text { AT1 Heating Fuels ( } n=2150)\end{array}$} \\
\hline & $\begin{array}{c}\text { None } \\
(n=362)\end{array}$ & $\begin{array}{c}\text { One } \\
(n=372)\end{array}$ & $\begin{array}{c}\text { Two or More } \\
(n=1416)\end{array}$ \\
\hline Single-Family Detached Home & $74 \%$ & $84 \%$ & $92 \%$ \\
\hline 2-4 Family Home-Duplex-Townhouse & 2 & 3 & 2 \\
\hline Building with More than 4 Units & 1 & 0 & 0 \\
\hline Mobile Home-Trailer & 23 & 13 & 6 \\
\hline
\end{tabular}


23\% of the nonpurchasers and $13 \%$ of the single-measure purchasers tive in mobile home-trailers, while onty $6 \%$ of the repeat purchasers live in that type of residence. Households that use electricity as a heating fuel display a very similar relationship between type of residence and number of conservation measures purchased (see Table 3.2.B). Since the type of residence can be a function of the level of total household income, and the types and number of ECMs that apply to mobile home-trailers are normally different than those that apply to single-family detached homes, the results suggest that higher income households in single-family detached homes are more inclined to make repeat investments in several conservation measures.

An obvious relationship did not exist between the level of education attained by the most formally educated adult resident in the househoid and the homeowners' past conservation purchase behavior. This was true for all homeowners as well as for those who use electricity as a heating fuel (see Table 3.3.A and Tabie 3.3.B.)

\subsection{OTHER FACTORS THAT INFLUENCE PURCHASE BEHAVIOR}

A11 of the homeowners who reported investing in one or more of the 12 ECMs covered in this survey were asked if they received any unexpected benefits from any or ail of the conservation actions they had taken thus far. Their verbatim responses were recoded into four categories: 1) None, 2) Monetary, 3) Comfort

TABLE 3.2.B. Number of Energy Conservation Measures Homeowners Have Purchased, by the Type of Current Residence

\begin{tabular}{|c|c|c|c|}
\hline \multirow[b]{2}{*}{ Type of Residence } & \multicolumn{3}{|c|}{$\begin{array}{c}\text { Number of Energy } \\
\text { Conservation Measures } \\
\text { Homeowners (in 1000s) } \\
\text { Heating Fuel Electric }(n=1262)\end{array}$} \\
\hline & $\begin{array}{l}\text { None } \\
(n=218)\end{array}$ & $\begin{array}{c}\text { One } \\
(n=231)\end{array}$ & $\begin{array}{c}\text { Two or More } \\
(n=813)\end{array}$ \\
\hline Single..Family Detached Home & $66 \%$ & $80 \%$ & $89 \%$ \\
\hline 2-4 Famity Home-Dupiex-Townhouse & 2 & 4 & 1 \\
\hline Building with More than 4 Units & 2 & 0 & 1 \\
\hline Mobile Home-Trailer & 31 & 16 & 8 \\
\hline
\end{tabular}


TABLE 3.3.A. Number of Energy Conservation Measures Homeowners Have Purchased, by Level of Education

\begin{tabular}{|c|c|c|c|}
\hline Level of Education (a) & $\begin{array}{c}\text { None } \\
(n=359)\end{array}$ & $\begin{array}{c}\text { One } \\
(n=367) \\
\end{array}$ & $\begin{array}{l}\text { Two or More } \\
(n=1414)\end{array}$ \\
\hline High School Degree or Less & $35 \%$ & $31 \%$ & $37 \%$ \\
\hline Some Coljege & 27 & 25 & 30 \\
\hline Complete College or Trade School & 22 & 31 & 20 \\
\hline Some Graduate School or More & 16 & 12 & 13 \\
\hline
\end{tabular}

(a) Residences were categorized by education according to the most formally educated adult resident in the household.

TABLE 3.3.B. Number of Energy Conservation Measures Homeowners have Purchased, by Level of Education

\begin{tabular}{|c|c|c|c|}
\hline \multirow[b]{2}{*}{ Level of Education (a) } & \multicolumn{3}{|c|}{$\begin{array}{l}\text { Number of Energy } \\
\text { Conservation Measures } \\
\text { Homeowners (in 1000s) } \\
\text { ing Fuel Electric }(n=1259 \text { ) }\end{array}$} \\
\hline & $\begin{array}{l}\text { None } \\
\langle n=215\rangle\end{array}$ & $\begin{array}{c}\text { One } \\
(n=231) \\
\end{array}$ & $\begin{array}{c}\text { Two of More } \\
(n=813)\end{array}$ \\
\hline High School Degree or Less & $39 \%$ & $34 \%$ & $37 \%$ \\
\hline Some College & 31 & 23 & 33 \\
\hline Complete College or Trade School & 17 & 25 & 19 \\
\hline Some Graduate School or More & 14 & 18 & 11 \\
\hline
\end{tabular}

(a) Residences were categorized by education according to the most formally educated adult resident in the household.

and 4) Save energy. Monetary (2) responses included: save money, save heating costs, conservation rebate, and increased value of home. Comfort (3) responses included: even room temperature, less household draft and more comfort. Save energy (4) responses included: save or decrease energy consumption. Homeowners who installed only one conservation measure reported more frequently than did repeat purchasers $(82 \%$ versus $76 \%)$ that they did not receive any 
unexpected benefits (see Table 3.4.A.). Almost $10 \%$ of the repeat purchasers reported monetary as an unexpected benefit, while none of the single-measure purchasers reported it. Homeowners who use electricity as a heating fuel and who installed only one conservation measure also reported more frequently than did repeat purchasers (79\% versus 71\%) that they did not receive any unexpected benefits. Homeowners using electricity were different from the entire sample when reporting comfort as an unexpected benefit. For homeowners using electricity, $21 \%$ of the single-measure purchasers and $17 \%$ of the repeat purchasers reported comfort as an unexpected benefit versus $11 \%$ of the single-measure purchasers and $13 \%$ of the repeat purchasers from the entire sample (see Table 3.4.8.) Thus, receiving unexpected monetary benefits may serve as an incentive for further investment by repeat purchasers; and comfort may be a very important incentive for homeowners who use electricity as a heating fuel.

Another way to assess whether repeat purchasers need more of an incentive to undertake further investment in ECMs is to look at the reasons given by this segment for not installing additional measures. The distribution of reasons given by nonpurchasers, single-measure purchasers, and repeat purchasers for the entire sample and for households that use electricity, is shown in Tables 3.5.A and 3.5.8. The reasons given were approximately the same for each of the three purchase groups. Nearly $60 \%$ of the homeowners in each group

TABLE 3.4.A. Number of Energy Conservation Measures Homeowners Have Purchased, by Unexpected Benefits Received

\begin{tabular}{|c|c|c|}
\hline \multirow[b]{2}{*}{$\begin{array}{l}\text { Unexpected } \\
\text { Benefits }\end{array}$} & \multicolumn{2}{|c|}{$\begin{array}{c}\text { Number of Energy } \\
\text { Conservation Measures } \\
\text { Homeowners (in 1000s) } \\
\text { AIT Heating Fuels } \\
(n-442)\end{array}$} \\
\hline & $\begin{array}{c}\text { One } \\
(n=68)\end{array}$ & $\begin{array}{l}\text { Two or More } \\
(n=346)\end{array}$ \\
\hline None & $82 \%$ & $76 \%$ \\
\hline Monetary & 0 & 9 \\
\hline Comfort & 11 & 13 \\
\hline Save Energy & 7 & 2 \\
\hline
\end{tabular}


TABLE 3.4.B. Number of Energy Conservation Measures Homeowners Have Purchased, by Unexpected Benefits Received

\begin{tabular}{|c|c|c|}
\hline \multirow[b]{2}{*}{$\begin{array}{l}\text { Unexpected } \\
\text { Benefits }\end{array}$} & \multicolumn{2}{|c|}{$\begin{array}{l}\text { Number of Energy } \\
\text { Conservation Heasures } \\
\text { Homeowners (in 1000s) } \\
\text { Heating Fue) Electric } \\
\text { Electric }(n=232)\end{array}$} \\
\hline & $\begin{array}{l}\text { One } \\
(n=36)\end{array}$ & $\begin{array}{l}\text { Two or More } \\
(n=181)\end{array}$ \\
\hline None & $79 \%$ & $71 \%$ \\
\hline Monetary & 0 & 7 \\
\hline Comfort & 21 & 17 \\
\hline Save Energy & 0 & 4 \\
\hline
\end{tabular}

TABLE 3.5.A. Number of Energy Conservation Measures Homeowners Have Purchased, by Reasons that Might Prevent Homeowners from Installing Additional Energy Conservation Measures

\begin{tabular}{|c|}
\hline $\begin{array}{l}\text { Reason } \\
\text { Not to Invest }\end{array}$ \\
\hline Cost \\
\hline Don't Need \\
\hline Planning to Move \\
\hline Time/Bother \\
\hline Nothing \\
\hline Other \\
\hline
\end{tabular}
Number of Energy
Conservation Measures Homeowners (in 1000 s)

A) 1 Heating Fuels $(n=1892)$

$\begin{array}{ccc}\begin{array}{c}\text { None } \\ (n=322)\end{array} & \begin{array}{c}\text { One } \\ (n=329)\end{array} & \begin{array}{c}\text { Two or More } \\ (n=1241)\end{array} \\ 65 \% & \frac{(n \%}{59 \%} & \frac{59 \%}{2 \%}\end{array}$

27

6

21

27

3

9

10

0

0

$5 \quad 3$

1

21

reported cost as the primary barrier to further investment. Next, the barrier most frequently mentioned (20\% to $30 \%$ in all groups) was not needing additional ECMs.

In terms of potential sources of funding future conservation investment, there appear to be interesting differences among the three types of purchase groups. The distribution of funding sources for the entire sample can be seen in Table 3.6.A. Nonpurchasers and single-measure purchasers were slightly more 
TABLE 3.5.8. Number of Energy Conservation Measures Homeowners Have Purchased, by Reasons that Might Prevent Homeowners from Installing Additional Energy Conservation Measures

\begin{tabular}{l} 
Reason \\
Not to Invest \\
\hline Cost \\
Don't Need \\
Planning to Move \\
Time/Bother \\
Nothing \\
Other
\end{tabular}

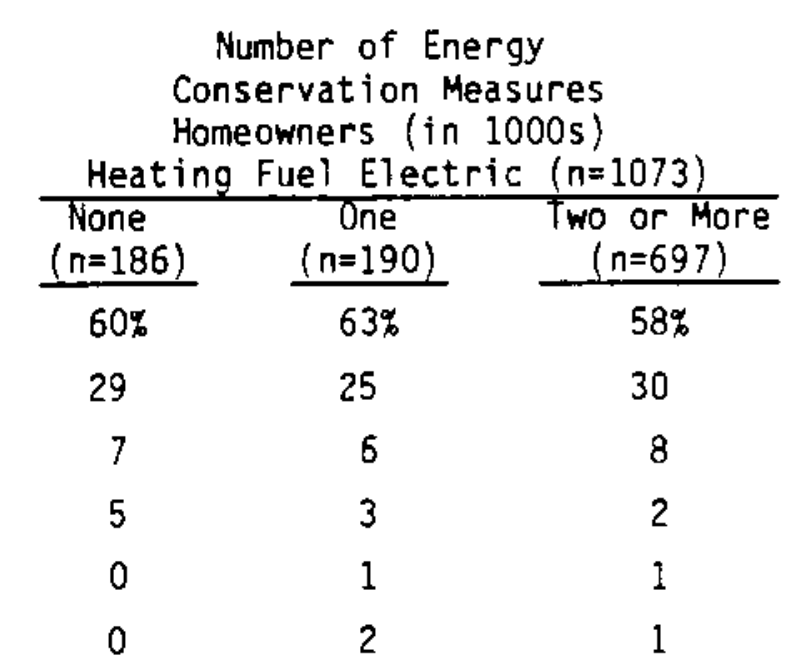

TABLE 3.6.A. Number of Energy Conservation Measures Homeowners Have Purchased, by Potential Sources of Funding for Future Investment in Energy Conservation Measures

\begin{tabular}{|c|c|c|c|}
\hline \multirow[b]{2}{*}{$\begin{array}{l}\text { Potential } \\
\text { Sources of Funding }\end{array}$} & \multicolumn{3}{|c|}{$\begin{array}{l}\text { Number of Energy } \\
\text { Conservation Measures } \\
\text { Homeowners (in 1000s) } \\
\text { All Heating Fuels }(n=1531)\end{array}$} \\
\hline & $\begin{array}{l}\text { None } \\
(n=235)\end{array}$ & $\begin{array}{c}\text { One } \\
(n=250)\end{array}$ & $\begin{array}{l}\text { Two or More } \\
(n=1046)\end{array}$ \\
\hline Money from Current Income & $15 \%$ & $16 \%$ & $11 \%$ \\
\hline Money from Savings & 13 & 6 & 9 \\
\hline Payments by Utility & 20 & 31 & 26 \\
\hline Federal Tax Credits & 1 & 0 & 2 \\
\hline Bank Loans/Credits & 37 & 34 & 41 \\
\hline Utility Loan & 10 & 12 & 10 \\
\hline Paid by other & 3 & 0 & 1 \\
\hline Combination of Sources & 1 & 0 & 0 \\
\hline other & 0 & 1 & 0 \\
\hline
\end{tabular}

willing to use current income than were repeat purchasers (15\%, $16^{\circ}$ versus 11\%). Nonpurchasers did not mention payments by the utility as a potential source of funds as often as did single-measure and repeat purchasers (20\% 
versus $31 \%, 26 \%$ ). The results do change, however, when only considering households that use electricity. Overall, nonpurchasers and single-measure purchasers who use electricity were more likely to mention payments by the utility as a funding source than were purchasers from the entire sample (28\% to $42 \%$ versus $20 \%$ to $31 \%$ ) (see Table 3.6.3.). These results may also indicate the positive effects of energy conservation programs sponsored by the BPA or electric utilities. Repeat purchasers in households using electricity mentioned bank loans/credits as a funding source more frequently than nonpurchasers and single-measure purchasers $(41 \%$ versus $34 \%, 34 \%)$. The results might indicate that repeat and single-measure purchasers in electrically heated homes are more aware of funding sources and of the benefits of investing in ECMs. This knowledge could also serve as an impetus to the consumer to further invast in conservation. There were very few differences found between the purchase behavior groups in the entire sample and for households using electricity, and the number of conservation measures that they indicated they were somewhat or very likely to install in the next two or three years (see Tabies 3.7.A. and 3.7.B.). Between $19 \%$ and $26 \%$ of the homeowners in each group indicated that

\begin{tabular}{|c|c|c|c|}
\hline \multirow[b]{2}{*}{$\begin{array}{l}\text { Potential } \\
\text { Sources of Funding }\end{array}$} & \multicolumn{3}{|c|}{$\begin{array}{l}\text { Number of Energy } \\
\text { Conservation Measures } \\
\text { Homeowners (in lo00s) } \\
\text { Heating Fuel Electric (n=903) }\end{array}$} \\
\hline & $\begin{array}{c}\text { None } \\
(n=141)\end{array}$ & $\begin{array}{c}\text { One } \\
(n=144) \\
\end{array}$ & $\begin{array}{c}\text { Two or More } \\
(n=619)\end{array}$ \\
\hline Money from Current Income & $12 \%$ & $7 \%$ & $10 \%$ \\
\hline Money from Savings & 11 & 2 & 8 \\
\hline Payments by Utility & 28 & 42 & 28 \\
\hline Federal Tax Credits & 1 & 0 & 3 \\
\hline Bank Loans/Credits & 34 & 34 & 41 \\
\hline Utility Loan & 7 & 13 & 11 \\
\hline Paid by other & 6 & 0 & 0 \\
\hline Combination of Sources & 1 & 0 & 0 \\
\hline Other & 0 & 1 & 0 \\
\hline
\end{tabular}


TABLE 3.7.A. Number of Energy Conservation Measures Homeowners Have Purchased, by the Number of Energy Conservation Measures They Are Somewhat or Very Likely to Install in the Next Two or Three Years

\begin{tabular}{|c|c|c|c|}
\hline \multirow{2}{*}{$\begin{array}{l}\text { Number of } \\
\text { Energy } \\
\text { Conservation } \\
\text { Measures } \\
\text { Somewhat or } \\
\text { Very Likely } \\
\text { to Install }\end{array}$} & \multicolumn{3}{|c|}{$\begin{array}{c}\text { Number of Energy Conservation } \\
\text { Homeowners (in 1000s) } \\
\text { All Heating Fuels }\end{array}$} \\
\hline & $\begin{array}{c}\text { Nonpurchasers } \\
(n=362)\end{array}$ & $\begin{array}{c}\text { Single-Measure } \\
\text { Purchasers } \\
(n=372) \\
\end{array}$ & $\begin{array}{l}\text { Repeat } \\
\text { Purchasers } \\
(n=1416) \\
\end{array}$ \\
\hline 0 & $33 \%$ & $38 \%$ & $38 \%$ \\
\hline $1-2$ & 42 & 37 & 41 \\
\hline 3 or More & 26 & 26 & 21 \\
\hline
\end{tabular}

TABLE 3.7.8. Number of Energy Conservation Measures Homeowners Have Purchased, by the Number of Energy Conservation Measures They Are Somewhat or Very Likeiy to Install in the Next Two or Three Years

\begin{tabular}{c} 
Number of \\
Energy \\
Conservation \\
Measures \\
Somewhat or \\
Very Likely \\
to Install \\
\hline
\end{tabular}

0

$1-2$

3 or More
Number of Energy Conservation Measures Homeowners (in 10005) Heating Fuel Electric

$\begin{array}{ccc}\begin{array}{c}\text { Nonpurchasers } \\ (n=218)\end{array} & \begin{array}{c}\text { Single-Measure } \\ \text { Purchasers } \\ (n=231)\end{array} & \begin{array}{c}\text { Repeat } \\ \text { Purchasers } \\ (n=813)\end{array} \\ & 41 \% & \frac{37 \%}{37 \%}\end{array}$

38

42

19

21

21

they were somewhat or very likely to install three or more measures while 33\% to $37 \%$ of the homeowners in each group indicated that they were somewhat or very likeiy to install no measures. One difference worth noting is for nonpurchasers. Less than $20 \%$ of this group in househoids using electricity reported that they were somewhat or very likely to install tinree or more conservation measures, whereas over $25 \%$ of the nonpurchasers in the entire sample stated the same. The intention to act and the resulting behavior are seldom equivalent. Therefore, the actual percentages from groups that will make investments in three or more measures during the next two or three years will probabiy be lower than indicated here. However, since repeat purchasers have 
previously demonstrated purchase behavior on two or more occasions, their actions may more nearly reflect their intentions than will those of singlemeasure purchasers and nonpurchasers.

There was very little difference found between the average monthiy heating bill of the households in the entire sample and those using electricity, and past conservation purchase behavior of the respondents (see Tables 3.8.A and 3.8.B.). Single-measure purchasers had the highest percentage of average monthly energy bilis less than $\$ 50$ per month (27\% for the entire sample, $30 \%$ for households using electricity), and the lowest percentage of heating bills between $\$ 50$ and $\$ 75$ per month $(27 \%$ for the entire sample, $31 \%$ for households using electricity).

TABLE 3.8.A. Number of Energy Conservation Measures Homeowners Have Purchased, by Average Monthly Heating Bill

\begin{tabular}{|c|c|c|c|}
\hline \multirow[b]{2}{*}{$\begin{array}{c}\text { Average Monthiy } \\
\text { Energy Bill } \\
\end{array}$} & \multicolumn{3}{|c|}{$\begin{array}{l}\text { Number of Energy } \\
\text { Conservation Measures } \\
\text { Homeowners (in 1000s) } \\
\text { A11 Heating Fuels }(n=1895)\end{array}$} \\
\hline & $\begin{array}{c}\text { None } \\
(n=302)\end{array}$ & $\begin{array}{c}\text { One } \\
(n=315)\end{array}$ & $\begin{array}{l}\text { Two or More } \\
(n=1279) \\
\end{array}$ \\
\hline Less than $\$ 50$ & $18 \%$ & $27 \%$ & $22 \%$ \\
\hline$\$ 50$ to $\$ 75$ & 39 & 27 & 40 \\
\hline More than $\$ 75$ & 43 & 47 & 39 \\
\hline
\end{tabular}

TABLE 3.8.8. Number of Energy Conservation Measures Homeowners Have Purchased, by Average Monthly Heating Bill

\begin{tabular}{|c|c|c|c|}
\hline \multirow[b]{2}{*}{$\begin{array}{c}\text { Average Monthly } \\
\text { Energy Bil\} }\end{array}$} & \multicolumn{3}{|c|}{$\begin{array}{l}\text { Number of Energy } \\
\text { Conservation Measures } \\
\text { Homeowners (in 1000s) } \\
\text { ing Fuel Electric (n=1128) }\end{array}$} \\
\hline & $\begin{array}{l}\text { None } \\
(n=181) \\
\end{array}$ & $\begin{array}{l}\text { One } \\
(n=195)\end{array}$ & $\begin{array}{c}\text { Two or More } \\
(n=751)\end{array}$ \\
\hline Less than $\$ 50$ & $18 \%$ & $30 \%$ & $20 \%$ \\
\hline$\$ 50$ to $\$ 75$ & 40 & 31 & 40 \\
\hline More than $\$ 75$ & 42 & 39 & 40 \\
\hline
\end{tabular}




\subsection{HOMEOWNERS' ATTITUDES THAT INFLUENCE PURCHASE BEHAVIOR}

To facilitate the understanding of consumer motivation to invest in ECMs, the purchase behavior categories were analyzed according to responses to severa? attitude statements. An average of $60 \%$ of all homeowners from the entire sample as well as from households using electricity in each purchase behavior category "strongly disagreed" or "disagreed" with the statement, "I have a) ready done everything I can to conserve energy" (see Tables 3.9.A and 3.9.B.). This would indicate that even though some homeowners may not yet have invested in ECMs, they do recognize the things they can do to conserve energy in their homes. This group may need only to gain sufficient knowledge about possible conservation measures to be motivated toward investment. The responses to this statement also indicate that repeat purchasers are aware of additional ECM investment possibilities for their homes.

Over B0\% of the homeowners from both the entire sample and from the households using electricity in each purchase behavior category "disagreed" or "strongly disagreed" with the statement, "Utilities should stop offering a variety of programs to encourage energy conservation" (see Tabies 3.10.A and 3.10.B.). Even though most of the homeowners prefer that the utilities

TABLE 3.9.A. Number of Energy Conservation Measures Homeowners Have Purchased, by Homeowners' Attitudes Toward Their Own Energy Conservation Efforts

\begin{tabular}{|c|c|c|c|}
\hline \multirow[b]{2}{*}{ Responses (a) } & \multicolumn{3}{|c|}{$\begin{array}{l}\text { Number of Energy } \\
\text { Conservation Measures } \\
\text { Homeowners (in 1000s) } \\
\text { A11 Heating Fuels }(n=2146)\end{array}$} \\
\hline & $\begin{array}{c}\text { Wone } \\
(n=360) \\
\end{array}$ & $\begin{array}{c}\text { One } \\
(n=373) \\
\end{array}$ & $\begin{array}{l}\text { Two or More } \\
(n=1414)\end{array}$ \\
\hline Strongly Disagree & $6 \%$ & $6 \%$ & $3 \%$ \\
\hline Disagree & 57 & 53 & 55 \\
\hline Neutral & 0 & 4 & 3 \\
\hline Agree & 33 & 32 & 33 \\
\hline Strongly Agree & 4 & 5 & 6 \\
\hline
\end{tabular}

(a) In response to the statement, "I have already done everything I can to conserve energy." 
TABLE 3.9.B. Number of Energy Conservation Measures Homeowners Have Purchased, by Homeowners' Attitudes Toward Their Own Energy Conservation Efforts

\begin{tabular}{|c|c|c|c|}
\hline \multirow[b]{2}{*}{ Responses (a) } & \multicolumn{3}{|c|}{$\begin{array}{l}\text { Number of Energy } \\
\text { Conservation Measures } \\
\text { Homeowners (in 1000s) }\end{array}$} \\
\hline & $\begin{array}{l}\begin{array}{l}\text { None } \\
(n=216)\end{array} \\
\end{array}$ & $\begin{array}{c}\text { One } \\
(n=231)\end{array}$ & $\begin{array}{c}\text { Two or More } \\
(n=811)\end{array}$ \\
\hline Strongly Disagree & $2 \%$ & $7 \%$ & $2 \%$ \\
\hline Disagree & 55 & 56 & 57 \\
\hline Neutral & 0 & 4 & 3 \\
\hline Agree & 39 & 31 & 31 \\
\hline Strongiy Agree & 3 & 3 & 7 \\
\hline
\end{tabular}

(a) In response to the statement, "I have already done everything I can to conserve energy."

TABLE 3.10.A. Number of Energy Conservation Measures Homeowners Have Purchased, by Homeowners' Attitudes Towards Utilities offering Conservation Programs

\begin{tabular}{|c|c|c|c|}
\hline \multirow[b]{2}{*}{ Responses (a) } & \multicolumn{3}{|c|}{$\begin{array}{l}\text { Number of Energy } \\
\text { Conservation Measures } \\
\text { Homeowners (in 1000s) } \\
\text { Al Heating Fuels }(n=2097)\end{array}$} \\
\hline & $\begin{array}{c}\text { None } \\
(n=343) \\
\end{array}$ & $\begin{array}{c}\text { One } \\
(n=365) \\
\end{array}$ & $\begin{array}{l}\text { Two or More } \\
(n=1389)\end{array}$ \\
\hline Strongly Disagree & $24 \%$ & $26 \%$ & $26 \%$ \\
\hline Disagree & 60 & 60 & 58 \\
\hline Neutral & 1 & 3 & 2 \\
\hline Agree & 15 & 9 & 12 \\
\hline Strongly Agree & 0 & 2 & 2 \\
\hline
\end{tabular}

(a) In response to the statement, "Utilities should stop offering a variety of programs to encourage energy conservation." 
TABLE 3.10.B. Number of Energy Conservation Measures Homeowners Have Purchased, by Homeowners' Attitudes Towards Utilities offering Conservation Programs

\begin{tabular}{|c|c|c|c|}
\hline \multirow[b]{2}{*}{ Responses (a) } & \multicolumn{3}{|c|}{$\begin{array}{l}\text { Number of Energy } \\
\text { Conservation Measures } \\
\text { Homeowners (in 1000s) } \\
\text { Heating Fuel Electric }(n=1232 \text { ) }\end{array}$} \\
\hline & $\begin{array}{l}\text { None } \\
(n=206)\end{array}$ & $\begin{array}{c}\text { One } \\
(n=226) \\
\end{array}$ & $\begin{array}{l}\text { Two or More } \\
(n=800) \\
\end{array}$ \\
\hline Strongly Disagree & $20 \%$ & $23 \%$ & $27 \%$ \\
\hline Disagree & 60 & 66 & 54 \\
\hline Neutral & 2 & 3 & 3 \\
\hline Agree & 18 & 5 & 14 \\
\hline Strongly Agree & 0 & 2 & 2 \\
\hline
\end{tabular}

(a) In response to the statement, "Utilities should stop offering a variety of programs to encourage energy conservation."

continue offering programs to encourage energy conservation, other results in this report indicate that most of these homeowners are not aware of specific utility programs. This finding reinforces the prospect of developing marketing strategies to help homeowners become aware of utility programs and to demonstrate the benefits of participating in them.

There were no differences found among households in the entire sampie or in households using electricity in each purchase behavior category in terms of responses to the statement, "Electricity prices in the Northwest are not high enough to necessitate conservation activities" (see Table 3.11. A and 3.11.8.). From $80 \%$ to $95 \%$ of the respondents in each purchase behavior category "strongly disagreed" or "disagreed" with the statement.

Neariy three-fourths of all repeat and nonpurchasers "strongly agreed" or "agreed" with the statement, "Conserving energy is the best way to protect the environment" (see Tables 3.12.A and 3.12.B.). Only two-thirds of all singlemeasure purchasers agreed with the statement. 
TABLE 3.11.A. Number of Energy Conservation Measures Homeowners Have Purchased, by Homeowners' Attitudes Towards Electricity Prices in the Northwest

\begin{tabular}{|c|c|c|c|}
\hline Responses (a) & $\begin{array}{c}\text { None } \\
(n=349)\end{array}$ & $\begin{array}{c}\text { One } \\
(n=354)\end{array}$ & $\begin{array}{c}\text { Two or More } \\
(n=1397)\end{array}$ \\
\hline Strongly Disagree & $25 \%$ & $27 \%$ & $24 \%$ \\
\hline Disagree & 67 & 58 & 63 \\
\hline Neutral & 0 & 5 & 1 \\
\hline Agree & 5 & 7 & 6 \\
\hline Strongly Agree & 2 & 1 & 1 \\
\hline
\end{tabular}
(a) In response to the statement, "Electricity prices in the Northwest are not high enough to necessi- tate conservation activities."

TABLE 3.11.B. Number of Energy Conservation Measures Homeowners Have Purchased, by Homeowners' Attitudes Towards Electricity Prices in the Northwest

\begin{tabular}{|c|c|c|c|}
\hline Responses (a) & $\begin{array}{c}\text { None } \\
(n=204)\end{array}$ & $\begin{array}{c}\text { One } \\
(n=217) \\
\end{array}$ & $\begin{array}{r}\text { Two or } M c \\
(n=802)\end{array}$ \\
\hline Strongly Disagree & $23 \%$ & $26 \%$ & $32 \%$ \\
\hline Disagree & 69 & 54 & 63 \\
\hline Neutral & 0 & 9 & 1 \\
\hline Agree & 5 & 8 & 4 \\
\hline Strongly Agree & 4 & 2 & 1 \\
\hline
\end{tabular}

Number of Energy Conservation Measures Homeowners (in 1000s) \begin{tabular}{cc} 
Heating Fuel Electric $(n=1226)$ \\
\hline None
\end{tabular} Number of Energy
Conservation Measures Homeowners (in 1000s) All Heating Fuels $(n=2100)$ 
TABLE 3.12.A. Number of Energy Conservation Measures Homeowners have Purchased, by Komeowners' Attitudes Toward Conserving Energy to Protect the Environment

\begin{tabular}{lcccc}
\multicolumn{1}{c}{ Responses $(a)$} & $\begin{array}{c}\text { None } \\
(n=334)\end{array}$ & & $\begin{array}{c}\text { One } \\
(n=354)\end{array}$ & $\begin{array}{c}\text { Two or More } \\
(n=1366)\end{array}$ \\
\cline { 1 - 1 } Strongly Disagree & & $2 \%$ & $1 \%$ & $0 \%$ \\
Disagree & 14 & 27 & 18 \\
Neutral & 8 & 5 & 5 \\
Agree & 67 & 59 & 67 \\
Strongly Agree & 8 & 9 & 9
\end{tabular}

Number of Energy

Conservation Measures

Homeowners (in 1000s)

All Heating Fuels $(n=2053)$

(a) In response to the statement, "Conserving energy is the best way to protect the environment."

TABLE 3.12.B. Number of Energy Conservation Measures Homeowners Have Purchased, by Homeowners' Attitudes Toward Conserving Energy to Protect the Environment

\begin{tabular}{|c|c|c|c|}
\hline \multirow[b]{2}{*}{ Responses $(a)$} & \multicolumn{3}{|c|}{$\begin{array}{l}\text { Number of Energy } \\
\text { Conservation Measures } \\
\text { Homeowners (in } 1000 \mathrm{~s}) \\
\text { Heating Fuel Electric }(n=1210)\end{array}$} \\
\hline & $\begin{array}{c}\text { None } \\
(n=204)\end{array}$ & $\begin{array}{c}\text { One } \\
(n=219) \\
\end{array}$ & $\begin{array}{c}\text { Two or More } \\
(n=787)\end{array}$ \\
\hline Strongly Disagree & $0 \%$ & $0 \%$ & $0 \%$ \\
\hline Disagree & 15 & 23 & 21 \\
\hline Neutral & 7 & 8 & 6 \\
\hline Agree & 70 & 58 & 64 \\
\hline Strongly Agree & 8 & 11 & 10 \\
\hline
\end{tabular}

(a) In response to the statement, "Conserving energy is the best way to protect the environment." 
Nonpurchasers were the largest group of respondents that "strongly agreed" or "agreed" with the statement, "It is our responsibility to conserve electricity for future generations" with $90 \%$ from the entire sample, 95\% from households using electricjty (see Tables 3.13.A and 3.13.B.). Repeat purchasers were the next largest group with $85 \%$ from the entire sample and $85 \%$ from households using electricity. Single-measure purchasers with $83 \%$ from the entire sample and $84 \%$ from households using electricity were the smallest group to "agree" or "strongly agree" with the statement.

\subsection{SUMMARY}

In sumary, homeowners who have purchased and/or invested in more than one ECM appear from the statistics to have high incomes, live in single-detached homes, report receiving unexpected monetary benefits from their conservation investments, and report utility and bank loans as potential fundings sources for conservation investments. The above characteristics are representative for repeat purchasers more frequently than for homeowners who are nonpurchasers or single measure purchasers.

TABLE 3.13.A. Number of Energy Conservation Measures Homeowners Purchased, by Homeowners' Attitudes Towards Conserving Electricity for Future Generations

\begin{tabular}{|c|c|c|c|}
\hline \multirow[b]{2}{*}{ Responses $(a)$} & \multicolumn{3}{|c|}{$\begin{array}{l}\text { Number of Energy } \\
\text { Conservation Measures } \\
\text { Homeowners (in 1000s) } \\
\text { A1l Heating Fuels ( } n=2098)\end{array}$} \\
\hline & $\begin{array}{c}\text { None } \\
(n=355)\end{array}$ & $\begin{array}{c}\text { One } \\
(n=359)\end{array}$ & $\begin{array}{l}\text { Two or More } \\
(n=1384)\end{array}$ \\
\hline Strongly Disagree & $1 \%$ & $1 \%$ & $1 \%$ \\
\hline Disagree & 6 & 14 & 11 \\
\hline Neutral & 3 & 1 & 3 \\
\hline Agree & 74 & 72 & 69 \\
\hline Strongly Agree & 16 & 11 & 16 \\
\hline
\end{tabular}

(a) In response to the statement, "It is our responsibility to conserve energy for future generations." 
TABLE 3.13.8. Number of Energy Conservation Measures Homeowners Purchased, by Homeowners' Attitudes Towards Conserving Electricity for Future Generations

\begin{tabular}{|c|c|c|c|}
\hline Responses (a) & $\begin{array}{l}\text { None } \\
(n=211)\end{array}$ & $\begin{array}{c}\text { One } \\
(n=219) \\
\end{array}$ & $\begin{array}{l}\text { Two or More } \\
(n=804)\end{array}$ \\
\hline Strongly Disagree & $0 \%$ & $0 \%$ & $1 \%$ \\
\hline Disagree & 5 & 15 & 11 \\
\hline Neutral & 0 & 1 & 3 \\
\hline Agree & 80 & 69 & 66 \\
\hline Strongly Agree & 15 & 15 & 19 \\
\hline
\end{tabular}

(a) In response to the statement, "It is our responsibility to conserve energy for future generations."

From these results, repeat purchasers of ECMs do not appear to need incentives to invest in additional energy conservation. Therefore, the hypothesis of repeat purchasers needing more of an incentive to invest in ECMs cannot be supported. Repeat purchasers are more able financially to invest and may have more interest in energy conservation because they live in single- detached family homes. Many conservation measures are designed for single- detached family homes as opposed to mobile homes. Moreover, since repeat purchasers more frequently reported monetary benefits as unexpected, it would appear that this group may be investing in conservation for reasons such as increased comfort. 


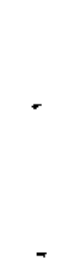




\subsection{UTILITY CONSERVATION PROGRAM PARTICIPATION}

Energy conservation programs sponsored by utilities are an important means to educate the public about reducing energy use in the home. In order to assess the levels of participation of some current conservation programs promoted by the utilities and/or the BPA, respondents were questioned about several programs and asked whether they had participated in any of them. In this chapter the following utility-sponsored programs are reviewed: Super Good Cents, Energy Guide Label, Solar and Heat Pump Water Heater program, and the Residential Weatherization program. Level of participation and the respondents' perceptions of the programs will be discussed. Because increased awareness of various ways to reduce energy use may encourage energy conservation activity, survey questions were designed to test the hypothesis that consumer behavior and intentions toward conservation vary by participation in utility sponsored conservation programs. This chapter contains an analysis of this hypothesis.

\subsection{AWARENESS OF UTILITY CONSERVATION PROGRAMS}

Among homeowners, approximately $56 \%$ of the entire sample and $55 \%$ of the households using electricity reported that they were aware of at least one utility-sponsored program that encourages energy conservation (see Figures 4.1.A and 4.1.B). However, when these respondents were asked to name a specific program, only $6 \%$ of them (entire sample and households using electricity) were able to do so (see Tables 4.1.A and 4.1.B). Residential Weatherization was the program most frequently mentioned by the respondents. However, it was mentioned more frequently by households that use electricity (45\%) than by the entire sample (38\%).

In turn, homeowners were asked what they knew about several utilitysponsored conservation programs. The programs included Super Good Cents, the Energy Guide Labei Program, the Solar and Heat Pump Water Heater Program and the Residential Weatherization program. Very few respondents ( $1 \%$ from both the entire sample and the households using electricity) volunteered an answer when 


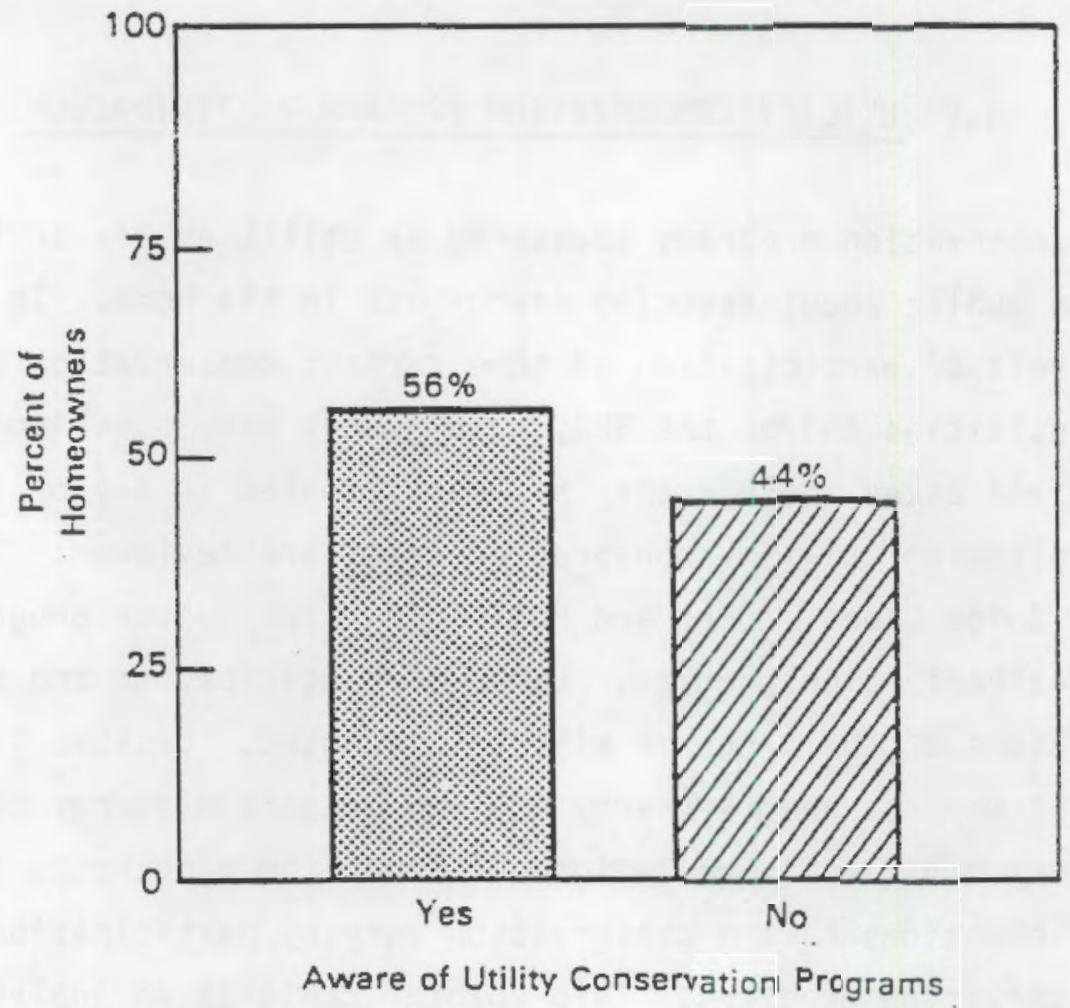

FIGURE 4.1.A. Aware of Utility Conservation Programs, All Heating Fuels $(n=2106)$

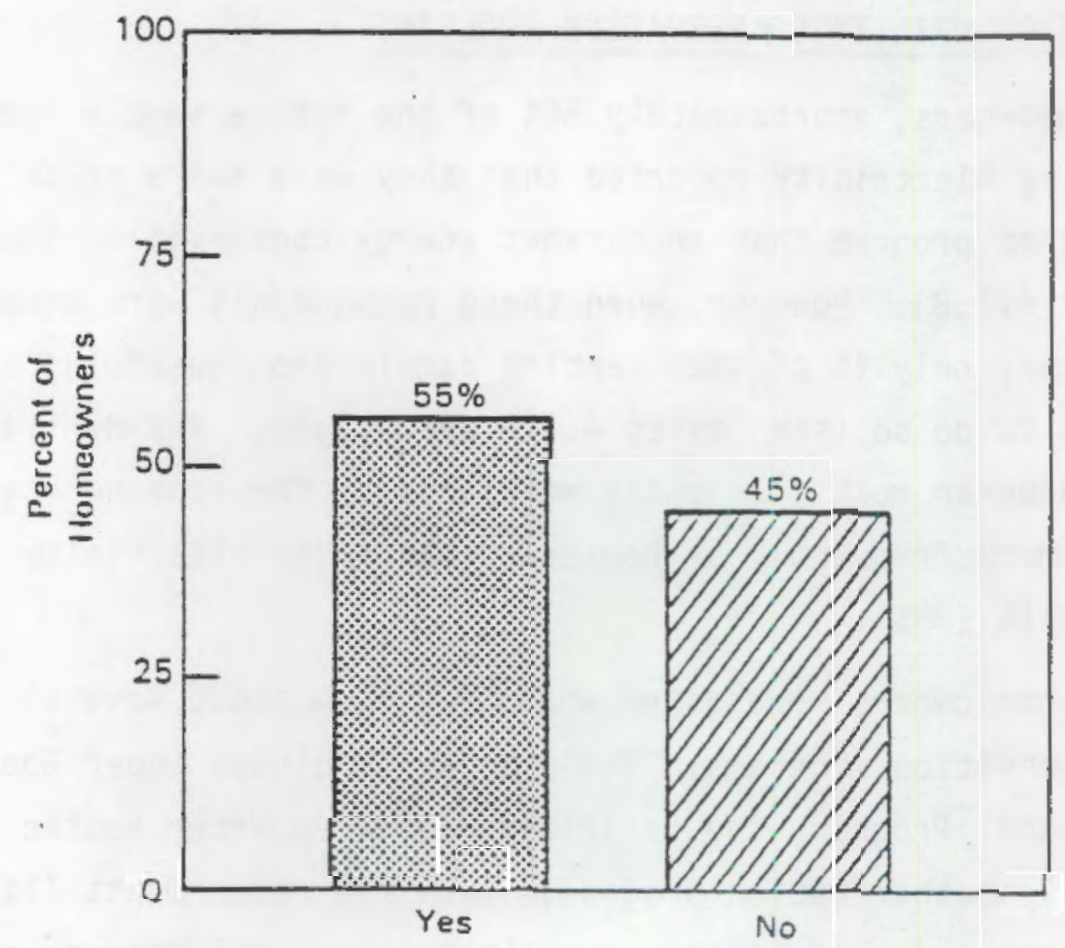

FIGURE 4.1.B. Aware of Utility Conservation Programs, Heating Fuel Electric $(n=1231)$ 
TABLE 4.1.A. Homeowner Awareness of Utility Conservation Programs

\begin{tabular}{ll}
\multicolumn{1}{c}{ Program } & $\begin{array}{c}\text { Number of } \\
\text { Homeowners } \\
\text { (in 1000s) } \\
\text { All Heat ing } \\
\text { Fuels ( } n=139)\end{array}$ \\
\cline { 2 - 2 } $\begin{array}{l}\text { Residential Weatherization } \\
\text { Other Weatherization }\end{array}$ & $38 \%$ \\
Solar and Heat Pump Water Heaters & 11 \\
Other Energy-Efficient Water Heaters & 8 \\
Super Good Cents & 8 \\
Other Energy-Efficient Homes & 6 \\
Energy Guide Label Program & 6 \\
Utility Audit & 7 \\
Other Energy-Efficient Appliances & 5 \\
Local Utility Low-Interest Loans & 2 \\
Portland Development Commission & 2 \\
Wind and Solar Energy Program & 2 \\
Hood River Valley Conservation Project & 2 \\
Idaho Weatherization Program (Loans) & 1 \\
Montana Energy Conservation Program & 2 \\
\end{tabular}

questioned about what is offered in the Super Good Cents program (see Tables 4.2.A and 4.2.B). Of those who offered a response, most knew in general what the program was about.

Respondents reported several potential sources for obtaining information about the energy consumption of new appliances (see Tables 4.3.A and 4.3.B). Knowing these sources may determine how best to inform the public about a product and its energy consumption. The most frequentiy mentioned sources were the local utility ( $23 \%$ from the entire sample, $24 \%$ from households using electricity), the dealer or store (23\% from the entire sample, $22 \%$ from households using electricity), followed by Consumer Guide magazine (21\% from the entire sample and $21 \%$ from households using electricity). 
TABLE 4.1.B. Homeowner Awareness of Utility Conservation Programs

\section{Program}

Residential Weatherization

Other Weatherization

Solar and Heat Pump Water Heaters

Other Energy-Efficient Water Heaters

Super Good Cents

Other Energy-Efficient Homes

Energy Guide Label Program

Utility Audit

Other Energy-Efficient Appliances

Local Utility Low-Interest Loans

Portland Development Commission

Wind and Solar Energy Program

Hood River Valley Conservation Project

Idaho Weatherization Program (Loans)

Montana Energy Conservation Program

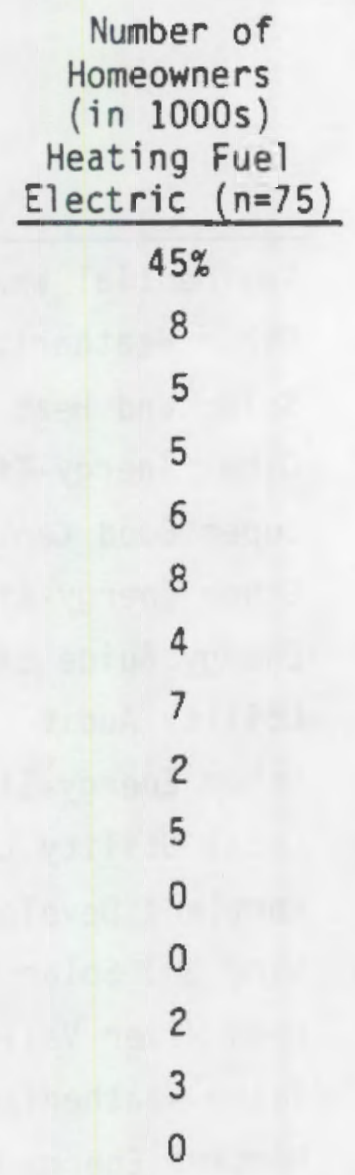

TABLE 4.2.A. Homeowner Perceptions of the Super Good Cents Program(a)

\begin{tabular}{ll} 
Program Feature & $\begin{array}{c}\text { Number of } \\
\text { Homeowners } \\
\text { (in 1000s) } \\
\text { All Heating } \\
\text { Fuels }(n=18)\end{array}$ \\
\hline Weatherization Measures for Home & $53 \%$ \\
Energy-Efficient Homes & 20 \\
Energy-Saving Tips & 17 \\
Common Sense Practices & 9
\end{tabular}

(a) In response to the questions, "What do you believe is offered in the Super Good Cents Program?" 
TABLE 4.2.B. Homeowner Perceptions of the Super Good Cents Program(a)

Number of

Homeowners

(in 1000s)

Heating Fuel

Program Feature

Weatherization Measures for Home

Electric $(n=12)$

$55 \%$

Energy-Efficient Homes

31

Energy-Saving Tips

0

Common Sense Practices

(a) In response to the questions, "What do you believe is offered in the Super Good Cents Program?" TABLE 4.3.A. Sources of Information About the Energy Consumption of New

Number of

Homeowners

(in 1000s)

Source

All Heating

Utility

Fuels $(n=634)$

Dealer-Store

$23 \%$

Consumer Guide

23

Appliance: Label or Brochure

21

Manufacturer

17

Consumer Organizations' Literature

Miscellaneous

6

2

(a) In response to the question, "If you were interested in getting information about the energy consumption of a new appliance, where do you think you could obtain it?" 
TABLE 4.3.B. Sources of Information About the Energy Consumption of New
Appliances $(a)$

\begin{tabular}{ll}
\multicolumn{1}{c}{ Source } & $\begin{array}{c}\text { Number of } \\
\text { Homeowners } \\
\text { (in 1000s) } \\
\text { Heating Fuel } \\
\text { Electric ( } n=366)\end{array}$ \\
\hline Utility & $24 \%$ \\
Dealer-Store & 22 \\
Consumer Guide & 21 \\
\hline Appliance: Label or Brochure & 18 \\
Manufacturer & 7 \\
Consumer Organizations' Literature & 5 \\
Miscellaneous & 3
\end{tabular}

(a) In response to the question, "If you were interested in getting information about the energy consumption of a new appliance, where do you think you could obtain it?"

Approximately $27 \%$ of the entire sample and $28 \%$ of households using electricity reported that they were very familiar with what is offered in the federal Energy Guide Label program (Figures 4.2.A and 4.2.B), and an additiona? $43 \%$ of the entire sample and households using electricity thought that they had heard of the program but were not sure what the program was about. Oniy 28\% of the entire sample and $27 \%$ of the households using electricity knew the correct color of the energy guide label (Figures 4.3.A and 4.3.B); of those, approximateiy $80 \%$ of the entire sample and $82 \%$ of households using electricity knew the purpose of the Energy Guide Label Program (see Tables 4.4.A and 4.4.B).

Approximately $10 \%$ of both the entire sample and of those households using electricity offered a response when asked what the Solar and Heat Pump Water Heater Program offers. Of those who responded, over $75 \%$ correctly knew about the program (see Tables 4.5.A and 4.5.B). Over $20 \%$ of the entire sample and of households using electricity responded to a question asking about the Residential Weatherization Program; more than $70 \%$ of the respondents from both groups knew what the program offered (see Table 4.6.A and 4.6.B). 


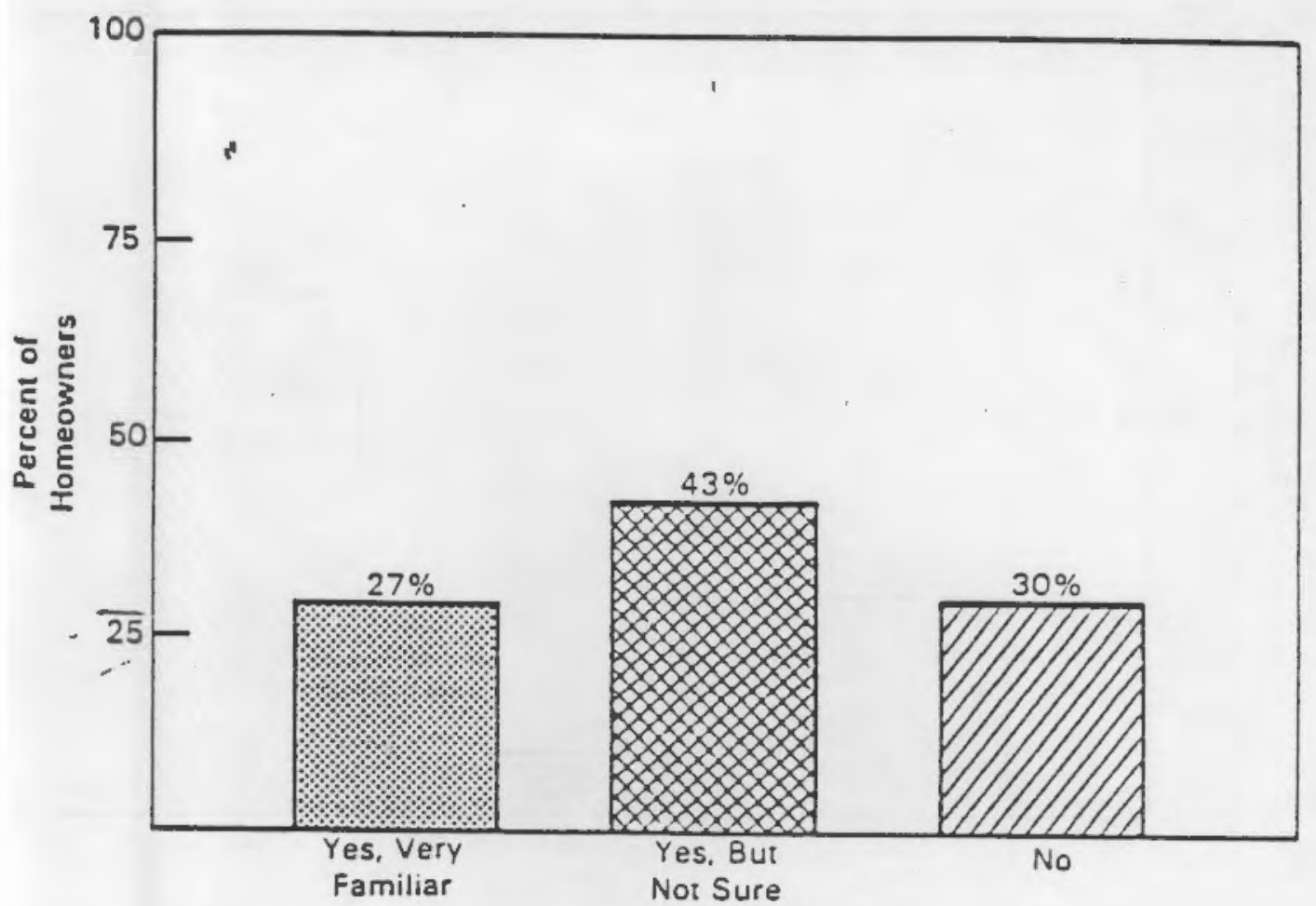

FIGURE 4.2.A. Aware of Federal Energy Guide Labels, All Heating Fuels $(n=2150)$

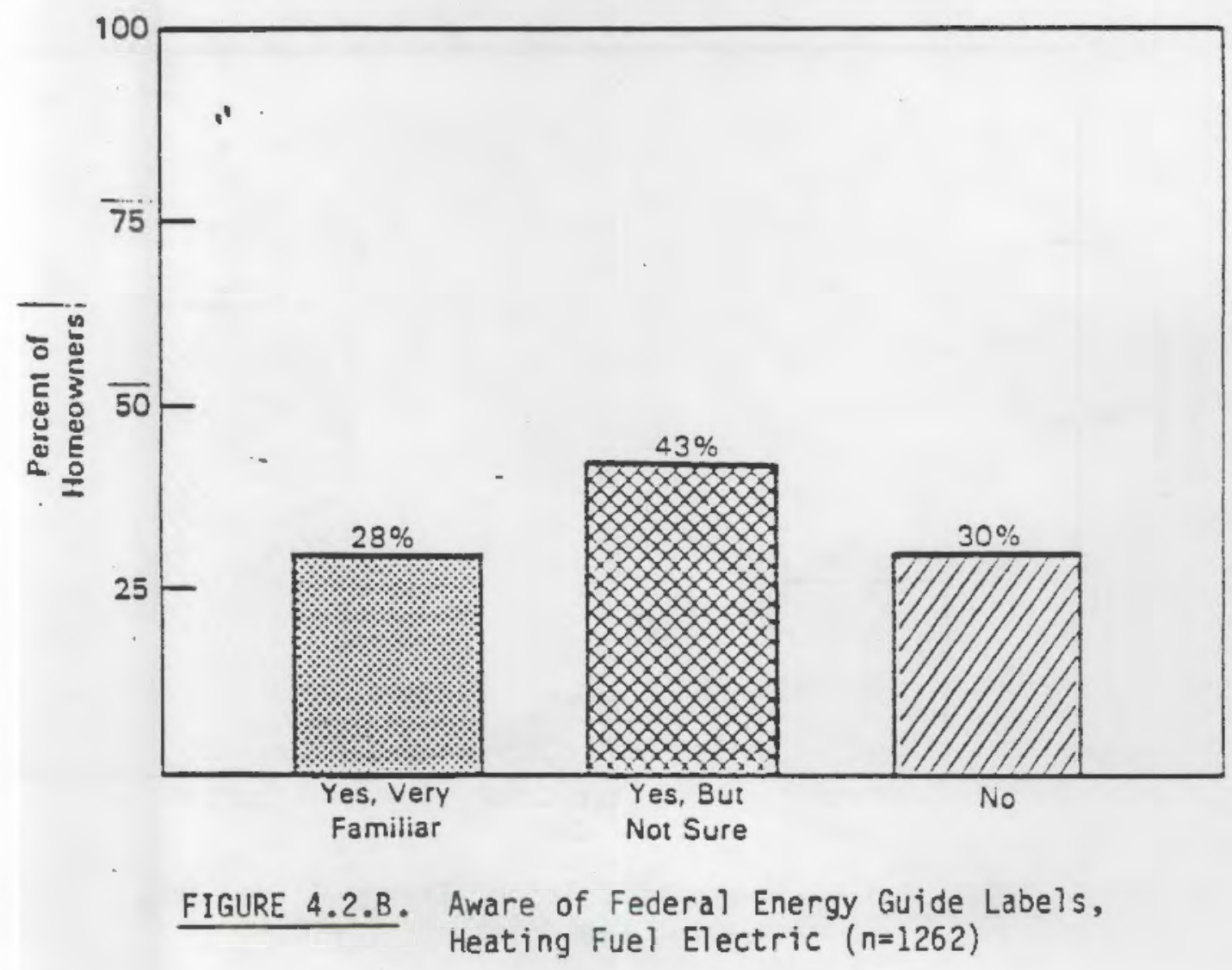




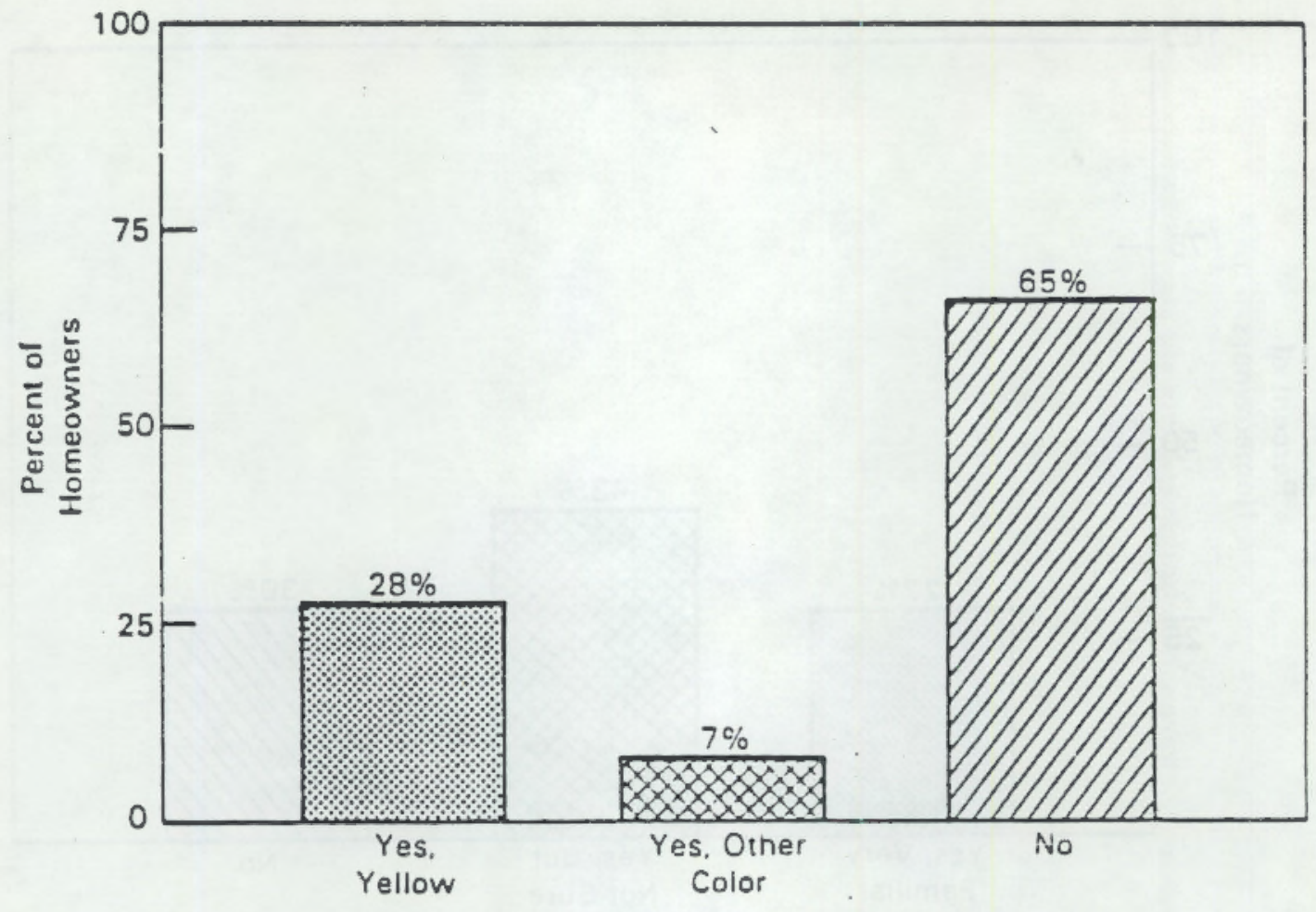

FIGURE 4.3.A. Aware of Color of Energy Guide Label, All Heating Fuels $(n=1803)$

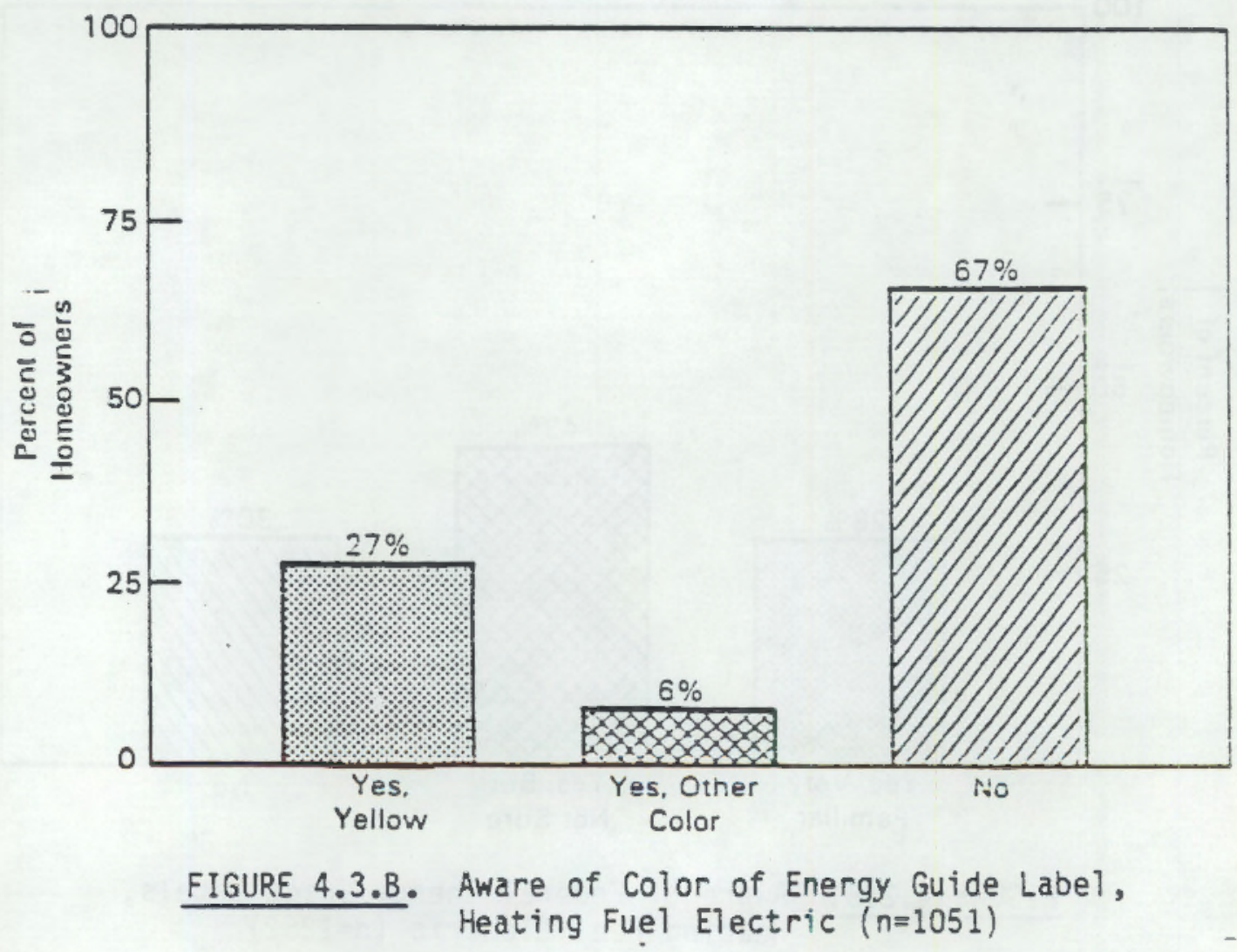


TABLE 4.4.A. Homeowner Perceptions of the Energy Guide Program(a)

\begin{tabular}{ll}
\multicolumn{1}{c}{ Program Features } & $\begin{array}{c}\text { Number of } \\
\text { Homeowners } \\
\text { (in 1000s) } \\
\text { All Heating } \\
\text { Homeowners } \\
\text { Fuels }(n=372)\end{array}$ \\
\hline $\begin{array}{l}\text { Efficient Appliances } \\
\text { Weatherization/Efficient New Homes }\end{array}$ & $\begin{array}{l}80 \% \\
\text { Miscellaneous }\end{array}$ \\
11
\end{tabular}

(a) In response to the question, "What do you believe is offered in the Energy Guide Program?"

TABLE 4.4.B. Homeowner Perceptions of the Energy Guide Program(a)

\begin{tabular}{ll} 
Program Features & $\begin{array}{c}\text { Number of } \\
\text { Homeowners } \\
\text { (in 1000s) } \\
\text { Heating Fuel } \\
\text { Efficient Appliances }\end{array}$ \\
Weatherization/Efficient New Homes & $\begin{array}{c}\text { Electric } \\
\text { Miscellaneous }\end{array}$ \\
\hline (a) In response to the question, "What do you believe
\end{tabular}

\subsection{PARTICIPATION IN UTILITY CONSERVATION PROGRAMS}

When asked if they had participated in any utility-sponsored programs, approximately $20 \%$ of both the entire sample and households using electricity reported that they had (see Figures 4.4.A and 4.4.B). However, fewer than 10\% of these homeowners were able to name the specific program (see Tables 4.7.A and 4.7.B). The most frequently mentioned program was Residential Weatherization (56\% from the entire sample, $67 \%$ from households using electricity). 
TABLE 4.5.A. Homeowner Perceptions of the Solar and Heat Pump Water Heater Program (a)

\begin{tabular}{|c|c|}
\hline Program Features & $\begin{array}{l}\text { Number of } \\
\text { Homeowners } \\
\text { (in 1000s) } \\
\text { All Heating } \\
\text { Fuels }(n=24) \\
\end{array}$ \\
\hline Energy-Efficient Water Heaters & $76 \%$ \\
\hline Energy-Efficient Appliances & 4 \\
\hline Tax Rebates, Credits & 5 \\
\hline Weatherization Measures to Your Home & 4 \\
\hline Energy-Efficient New Homes & 4 \\
\hline Energy-Saving Tips & 2 \\
\hline Common Sense Practices & 2 \\
\hline Heating Alternatives & 1 \\
\hline Financial Help for the Poor & 1 \\
\hline Items at Lower Cost & 1 \\
\hline
\end{tabular}

(a) In response to the question, "What do you believe is offered in the solar and heat pump water heater program?"

\subsection{RELATIONSHIP BETWEEN PARTICIPATION IN UTILITY CONSERVATION PROGRAMS} AND CONSERVATION INVESTMENT BEHAVIOR (PAST OR FUTURE)

Homeowner participation in a utility conservation program appears positively related to the number of energy conservation measures installed since moving into current residences. A larger proportion of homeowners who had participated in a least one utility program, compared to homeowners who had not, installed five or more conservation measures $137 \%$ versus $30 \%$ from the entire sample, $36 \%$ versus $30 \%$ from housenolds using electricity) (see Tables 4.8 . A and $3.8 . B)$.

Homeowners who participated in a program indicated a greater likelihood of installing three or more energy conservation measures during the next two to three years than did homeowners who had not participated in a utility sponsored 
TABLE 4.5.B. $\begin{gathered}\text { Homeowner Perceptions of the Solar and Heat Pump Water Heater } \\ \text { Program }\end{gathered}$

\begin{tabular}{ll}
\multicolumn{1}{c}{ Program Features } & $\begin{array}{c}\text { Number of } \\
\text { Homeowners } \\
\text { (in 1000s) } \\
\text { Heating Fuel } \\
\text { Electric }(n=128)\end{array}$ \\
\hline $\begin{array}{l}\text { Energy-Efficient Water Heaters } \\
\text { Energy-Efficient Appliances }\end{array}$ & 3 \\
Tax Rebates, Credits & 7 \\
Weatherization Measures to Your Home & 3 \\
Energy-Efficient New Homes & 4 \\
Energy-Saving Tips & 0 \\
Common Sense Practices & 3 \\
Heating Alternatives & 0 \\
Financial Help for the Poor & 1 \\
Items at Lower Cost & 3
\end{tabular}

(a) In response to the question, "What do you believe is offered in the solar and heat pump water heater program?"

program ( $31 \%$ versus $26 \%$ from the entire sample, $30 \%$ versus $21 \%$ from households using electricity) (see Tables 4.9.A and 4.9.8).

The amount of money spent by homeowners during the past two years to reduce energy use in the home was related positively to participation in a program (see Tables 4.10.A and 4.10.B). Between $40 \%$ and $45 \%$ of the entire sample and of households using electricity who had not participated in a utility program, spent no money to reduce energy use; whereas, over $80 \%$ of the homeowners who had participated in a program did spend money.

\subsection{SUMMARY}

The results indicate that consumer behavior and intentions toward conservation investment vary by participation in a utility-sponsored conservation program. These results in turn support rejecting the hypothesis that behavior 

TABLE 4.6.A. $\begin{gathered}\text { Homeowner } \\ \text { Program }\end{gathered}$

\begin{tabular}{c} 
Number of \\
Homeowners \\
(in 1000s) \\
All Heating \\
Fuels ( $n=520)$ \\
\hline $73 \%$ \\
10 \\
8 \\
3 \\
4 \\
3
\end{tabular}
(a) In response to the question, "What do you believe is offered in the residential weatherization program?"

TABLE 4.6.B. Homeowner Perceptions of the Residential Weatherization

\begin{tabular}{ll}
\multicolumn{1}{c}{ Program Features } & $\begin{array}{c}\text { Number of } \\
\text { Homeowners } \\
\text { (in 1000s) } \\
\text { Heating Fue } \\
\text { Electric }(n=274)\end{array}$ \\
${ } }$ & $72 \%$ \\
Audits & 10 \\
Energy-Efficient New Homes & 4 \\
Financial Aid & 4 \\
Efficiency Standards & 5 \\
Miscellaneous & 5
\end{tabular}

(a) In response to the question, "What do you believe is offered in the residential weatherization program?" 


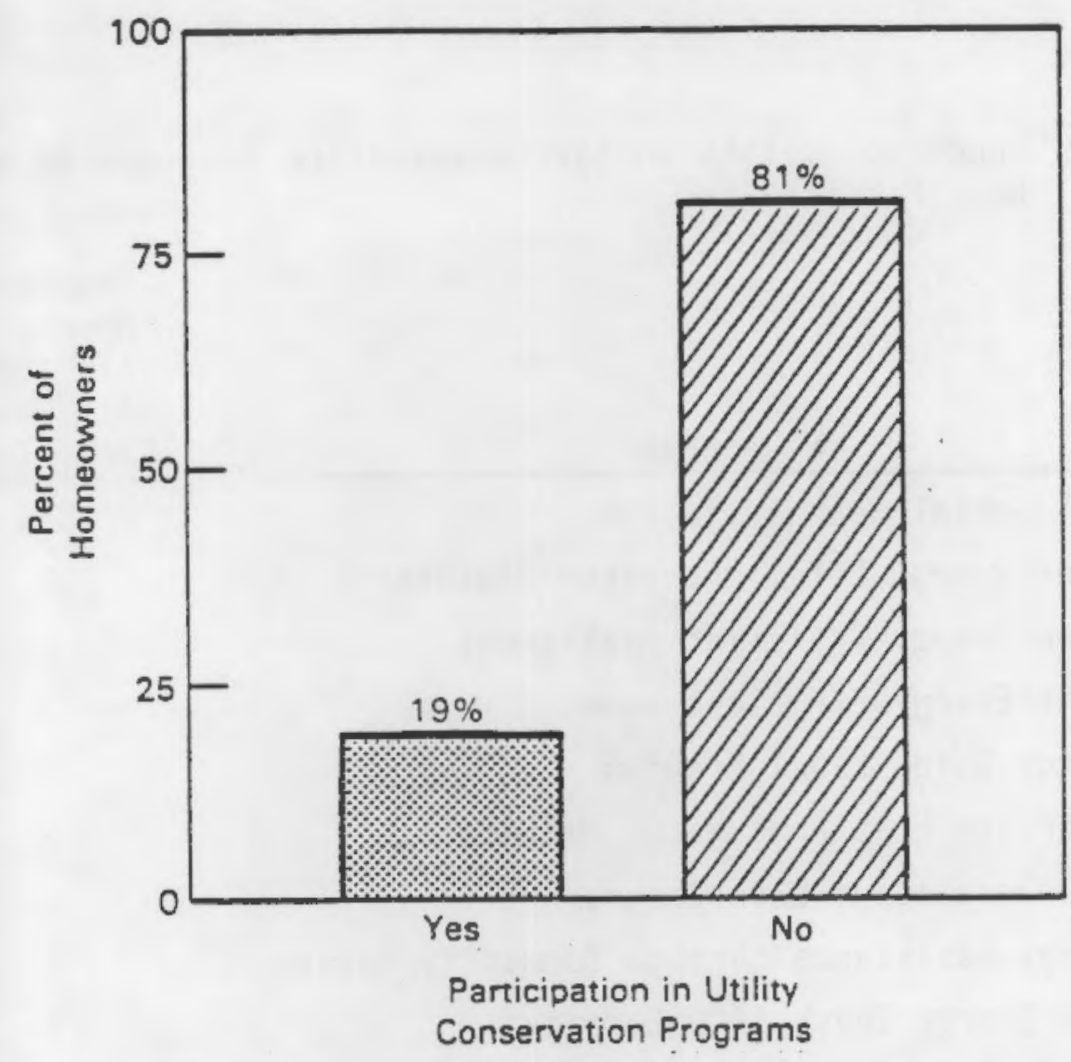

FIGURE 4.4.A. Participation in Utility Conservation Programs, All Heating Fuels $(n=1171)$

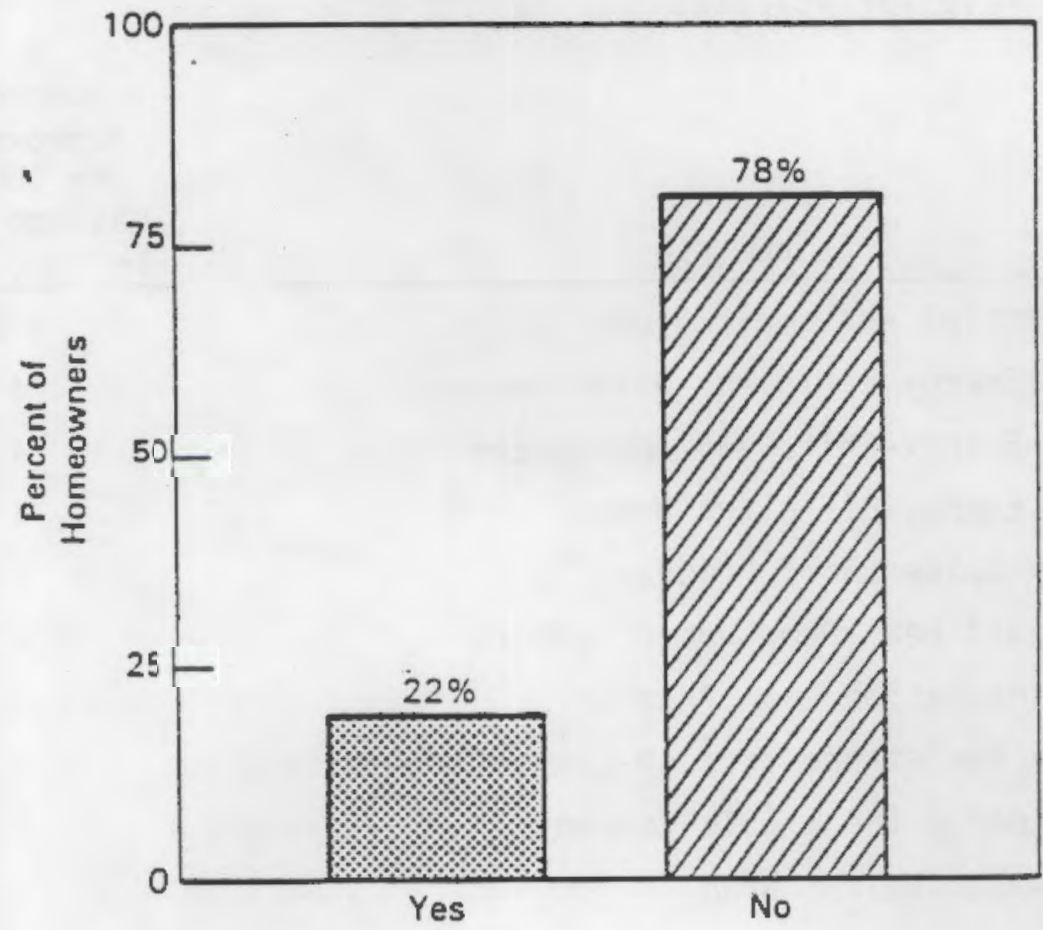

FIGURE 4.4.8. Participation in Utility Conservation Programs, Heating Fuel Electric $(n=670)$ 
TABLE 4.7.A. Specific Utility Energy Conservation Programs in Which Homeowners Have Participated

\begin{tabular}{l} 
Number of \\
Homeowners \\
(in 1000s) \\
All Heating \\
Fuels ( $n=61)$ \\
\hline
\end{tabular}

Residential Weatherization

$56 \%$

Other Energy-Efficient Water Heaters 13

Other Energy-Efficient Appliances 6

Other Energy-Efficient Homes 3

Energy Guide Label Program 3

Solar and Heat Pump Water Heaters 3

PP\&L Insulation Loan Program 5

Energy Assistance through Community Action 5

Home Energy Check ISCL Company 3

PP\&L water Heater Wrap 3

TABLE 4.7.B. Specific Utility Energy Conservation Programs in Which Homeowners Have Participated

\begin{tabular}{|c|c|}
\hline Program & $\begin{array}{l}\text { Number of } \\
\text { Homeowners } \\
\text { (in 1000s) } \\
\text { Heating Fuel } \\
\text { Electric }(n=48) \\
\end{array}$ \\
\hline Residential Weatherization & $67 \%$ \\
\hline Other Energy-Efficient Water Heaters & 4 \\
\hline Other Energy-Efficient Appliances & 4 \\
\hline Other Energy-Efficient Homes & 4 \\
\hline Energy Guide Label Program & 4 \\
\hline Solar and Heat Pump Water Heaters & 4 \\
\hline PP\&L Insulation Loan Program & 7 \\
\hline Energy Assistance through Community Action & 0 \\
\hline Home Energy Check ISCL Company & 4 \\
\hline PP\&L Water Heater Wrap & 4 \\
\hline
\end{tabular}


TABLE 4.8.A. Number of Energy Conservation Measures Installed by the Respondents Since Moving into Their Current Residence, Relative to Participation in a Utility Conservation Program

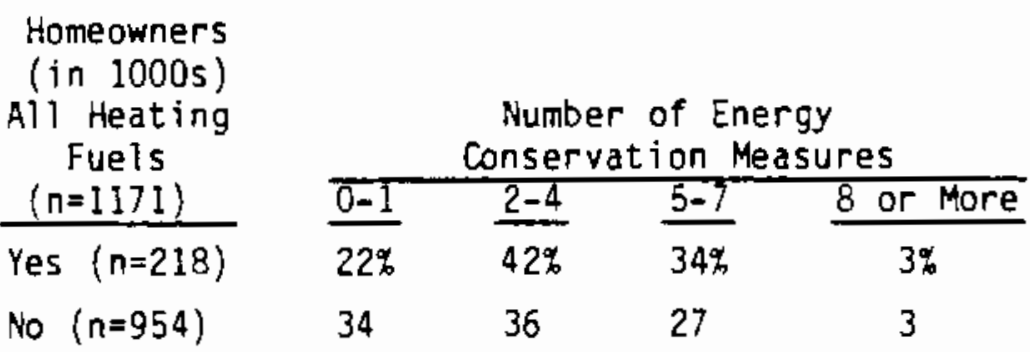

TABLE 4.8.B. Number of Energy Conservation Measures Installed by the Respondents Since Moving into Their Current Residence, Relative to Participation in a Utility Conservation Program

\begin{tabular}{lllll}
$\begin{array}{c}\text { Homeowners } \\
\text { (in 1000s) } \\
\text { Heating Fuel } \\
\text { Electric } \\
(n=670)\end{array}$ & $\frac{3}{0-1}$ & $\frac{3}{2-4}$ & $\begin{array}{c}\text { Number of Energy } \\
\text { Conservation Measures }\end{array}$ \\
\hline Yes $(n=150)$ & $27 \%$ & $\frac{5-7}{37 \%}$ & $\frac{8 \text { or More }}{32 \%}$ & $4 \%$ \\
No $(n=520)$ & 36 & 35 & 26 & 4
\end{tabular}

TABLE 4.9.A. Number of Energy Conservation Measures Homeowners are Somewhat or Very Likely to Install in the Next Two or Three Years, Relative to Participation in a Utility Conservation Program

\begin{tabular}{|c|c|c|c|c|}
\hline \multirow[t]{2}{*}{$\begin{array}{c}\text { Homeowners } \\
\text { (in 1000s) } \\
\text { A1 Heat ing } \\
\text { Fue } 15 \\
(n=1171)\end{array}$} & \multicolumn{4}{|c|}{$\begin{array}{l}\text { Number of Energy } \\
\text { Conservation Measures }\end{array}$} \\
\hline & $\underline{0}$ & $I-2$ & 3 & or More \\
\hline Yes $(n=218)$ & $33 \%$ & $36 \%$ & & $31 \%$ \\
\hline No $(n=954)$ & 36 & 38 & & 26 \\
\hline
\end{tabular}

and intention would not vary by participation in such a program. Over 35\% of homeowners who had participated in at least one utility-sponsored program had installed five or more conservation measures in their homes. However, $30 \%$ of those who had not participated in a utility-sponsored program had also installed five or more conservation measures. Comparing homeowners who had 
TABLE 4.9.B. Number of Energy Conservation Measures Homeowners are Somewhat or Very Likely to Install in the Next Two or Three Years, Relative to Participation in a Utility Conservation Program

\begin{tabular}{|c|c|c|c|}
\hline \multirow{3}{*}{$\begin{array}{l}\text { Homeowners } \\
\text { (in 1000s) } \\
\text { Heating Fue? } \\
\text { Electric } \\
(n=670)\end{array}$} & \multicolumn{3}{|c|}{$\begin{array}{l}\text { Number of Energy } \\
\text { Conservation Measures }\end{array}$} \\
\hline & & $\begin{array}{ll}\text { at or } \\
\text { to in }\end{array}$ & ry Likely \\
\hline & 0 & $1-2$ & 3 or More \\
\hline Yes $(n=150)$ & $32 \%$ & $38 \%$ & $30 \%$ \\
\hline No $(n=520)$ & 37 & 42 & 21 \\
\hline
\end{tabular}

TABLE 4.10.A. Amount Homeowners Spent During the Past Two Years to Reduce Energy Use in the Home, Relative to Participation in a Utility Conservation Program

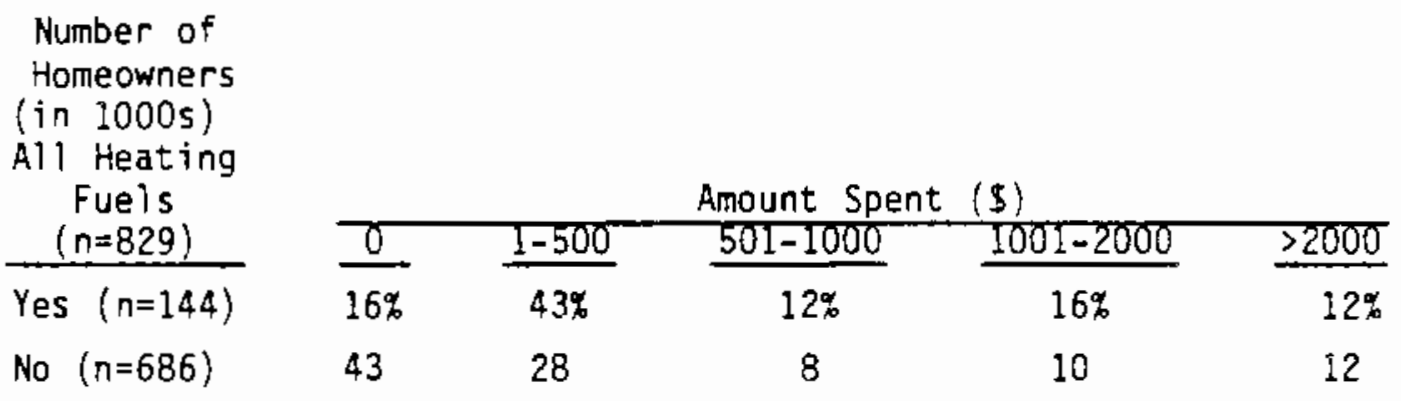

TABLE 4.10.B. Amount Homeowners Spent During the Past Two Years to Reduce Energy Use in the Home, Relative to Participation in a Utility Conservation Program

\begin{tabular}{|c|c|c|c|c|c|}
\hline $\begin{array}{l}\text { Number of } \\
\text { Homeowners } \\
\text { (in 1000s) } \\
\text { Heating Fuel } \\
\text { Electric }\end{array}$ & & & Anount Spent & (\$) & \\
\hline$(n=501)$ & 0 & $1-500$ & $501-1000$ & $1001-2000$ & $\geq 2000$ \\
\hline Yes $(n=109)$ & $16 \%$ & $49 \%$ & $15 \%$ & $18 \%$ & $2 \%$ \\
\hline No $(n=392)$ & 45 & 30 & 9 & 9 & 7 \\
\hline
\end{tabular}

participated in a utility-sponsored program with those who had not, those homeowners who had participated indicated a greater likelihood of jnvesting in three or more measures during the next two to three years. 


\section{D EXPECTED BENEFITS OF ENERGY CONSERVATION MEASURES}

The objective of this chapter is to test the hypothesis that consumer behavior and intentions toward conservation will not vary by the benefits expected from different energy conservation measures. First, the benefits that respondents expected to receive from each ECM are presented; then the benefits the respondents actually received are discussed. The results are broken down further to indicate the expected benefits of each ECM and whether or not those expected benefits were actually received.

As an additional task, the expected benefits from each ECM were broken down according to the date respondents installed them. These breakdowns by date demonstrate the stability of expectations over a period of time. The chapter finishes by reviewing the expected benefits from each EOM as expressed by those homeowners who stated they were somewhat or very likely to install those particular measures in the next two or three years.

\subsection{BENEFITS EXPECTED}

Respondents were asked which specific ECMs they had installed in their current homes. Those who had installed one or more measures were asked if the ECMs had been installed during the past two years or since they moved into their homes. They were also asked what benefits they expected from the $\operatorname{ECM}(s)$.

A good understanding of the respondents' expectations of each ECM provides useful insight in marketing conservation measures. A potential probiem may exist, for example, if respondents expect but do not receive significant monetary savings by weatherproofing their homes. A more appropriate marketing strategy might be to promote the more realistic benefit of weatherproofing, such as reducing drafts in the home which therefore increases comfort. Promoting programs and investment benefits which are realistic and consistent with expectations may also help increase repeat conservation investments.

Respondents reported more than 25 expected benefits from all of the ECMS being analyzed in the Phase II survey. To facilitate interpretation of the findings, the expected benefits were grouped into three categories: monetary, conservation and comfort. Monetary benefits included responses such as "save 
money" and "reduce heating costs." Conservation benefits included responses such as "reduce energy consumption" and "less energy consumption." Comfort benefits included "fewer household drafts" and "more comfort."

The benefits that respondents expected for each ECM are found in Figures 5.1.A to 5.12. A for the entire sample/all heating fuels and in Figures 5.1.B to 5.12.B for households using electricity. Respondents most frequentiy mentioned monetary and comfort as the benefits they expected from all of the ECMS, except for solar panels. Conservation was the most frequentiy mentioned benefit for solar panels. Monetary are those benefits most frequently mentioned from weatherproofing, heat pump furnaces, automatic or setback thermostats, heat pump water heaters, wood stoves and fireplace inserts. On the other hand, comfort was the most frequently mentioned benefit from storm windows, insulated basement floors or crawlspaces, insulated outside walls, insulated roofs or attics, and storm doors. The ECMs whose most frequentiy mentioned benefit was comfort appeared to offer more imediate results to respondents than did those ECMs whose most frequently mentioned benefit was monetary. There is an expectation of quick results from ECMs. Therefore, promotional campaigns emphasizing the benefits of a particular ECM may need to incorporate into the campaign strategy the expected time frame or wating period for the promoted benefits.

\subsection{BENEFITS RECEIVED}

Over $80 \%$ of the respondents in the entire sample and $90 \%$ of the respondents in households using electricity who have also installed ECMs, reported that they did receive their expected benefits (see Tables 5.1.A and 5.1.B). The ECM with the highest proportion of respondents who did not receive their expected benefits was the heat pump furnace. Almost $20 \%$ of the responderts in the entire sample and of those using electricity reported that they did not receive their expected benefits from the heat pumps.

Since an overwhelming majority of respondents who installed one or more ECM reported that they did receive their expectec benefits, the logical assumption is that respondents are satisfied with their ECM(s). However, a factor 
which must be considered in this assumption is the concept referred to as "cognitive dissonance." Cognitive dissonance occurs when someone (a consumer) is exposed to information that creates inconsistency or dissonance with attitudes or knowledge he holds. Thus, the consumer's personal attitudes are adjusted by revising old attitudes or by adopting new ones. For example, if a homeowner invests a large sum of money to insulate the attic and expects large monetary benefits, he will probably be disappointed if he doesn't receive these monetary benefits. Rather than be disappointed, the homeowner may convince himself that he had not expected large monetary benefits or that he actually expected to receive comfort benefits. This change of attitude would be particularly relevant for respondents who had spent large sums of money on the $\operatorname{ECM}(\mathrm{s})$. In the present study, the possible occurrence of cognitive dissonance must be considered. It is possible that some respondents stated that they had received their expected benefit(s) even though they were not sure that they had received the expected benefit or the degree of benefit they wanted.

In Tabies 5.2.A. to 5.13.A for the entire sample and 5.2.B to 5.13.8 for households that use electricity, responses are broken down by the specific ECM purchased and by the type of expected benefit. When respondents indicated that they had not received the expected benefits for weatherproofing, heat pump furnaces, automatic or setback thermostats, wood stoves/furnaces or fireplace inserts, over $50 \%$ stated that their expected benefit had been monetary. When respondents indicated that they had not received their expected benefits for insulated basement floor, insulated roof, or storm doors, over $50 \%$ of the time the expected benefit had been comfort.

Since a large segment of homeowners do expect monetary benefits from the ECMs instalied, they are dissatisfied when they do not save as much money as expected. Whether or not an ECM is promoted for its possible monetary benefits, it is worthwhile to address the issue of the savings that homeowners can realistically expect from installing specific measures.

\subsection{CHANGES IN EXPECTED BENEFITS}

One way to assess the reliability of the expected $E C M$ benefits is to record the change in expected benefits over a period of time. This can be done 
by looking at when the ECM was installed and what benefit the respondents expected at that time. In Tables 5.14.A to 5.25.A for the entire 5 ample and Tables 5.14.B to 5.25.B for households using electricity, the benefits expected from each ECM are compared according to date of instaliation. Only four of the conservation measures (heat pump furnaces, automatic thermostats, heat pump water heaters, and fireplace inserts) for the entire sample and for househoids using electricity had dramatic changes in the expected benefits over time. The expected benefits of solar panels changed dramatically for only the entire sample and not for the households using electricity. Over $10 \%$ of the entire sample and of households using electricity installed automatic thermostats and/or fireplace inserts. Therefore, the changes in their expected benefits will be reviewed. (Fewer than 5\% installed soiar panels and heat pump water heaters and fewer than $10 \%$ installed heat pump furnaces.) For automatic thermostats, comfort has recently been reported more frequently as a benefit. The opposite occurred for fireplace inserts; conservation benefits were reported more frequentiy while comfort benefit reportings decreased.

\subsection{BENEFITS EXPECTED BY RESPONDENTS SOMEWHAT OR VERY LIKELY TO INSTALL ENERGY CONSERVATION MEASURES}

Figures 5.13.A to 5.24.A for the entire sample and Figures 5.13.8 to 5.24.B for homeowners using eiectricity show the benefits expected by homeowners who are somewhat or very likely to install one or more ECM during the next two to three years. For 9 of the 12 conservation measures analyzed, respondents in the entire sample and househoids using electricity most frequently expected monetary benefits from weatherproofing, stom windows, heat pump furnaces, automatic thermostats, insulated outside walls, solar panels, heat pump water heaters, wod stove/furnaces, and fireplace inserts. Households using electricity exclusively expect monetary benefits also from insulated roof or attic and from storm doors. For the remining ECMs, insulated basement floor or crawlspace (entire sample and households using electricity), storm doors (entire sample), and insulated roof or attic (entire sample) record responses split evenly between monetary and comfort benefits. Six percent or iess of the entire sample and of homeowners using electricity mentioned conservation.as an expected benefit for any of the ECMs except for fireplace 
inserts. Of the respondents who were somewhat or very likely to install fireplace inserts, over $10 \%$ of the entire sample and over $20 \%$ of househoids using electricity mentioned conservation benefits.

\subsection{SUMMARY}

Households that had previously installed ECMs had expected monetary as well as comfort benefits. These expectations changed when respondents were asked about future ECM installation in the next two to three years. The results seem to give some support to rejecting the hypothes is that consumer behavior and intentions do not vary by the benefits expected from different ECMs. For more than three-fourths of the ECMs, respondents reported that they expected to receive primarily monetary benefits. Information such as this is very useful when designing marketing programs. If consumers expect monetary benefits and if they do not receive direct financial benefit, then marketing programs must be sensitive to this information. Marketing programs may decide to advertise that monetary benefits could vary and/or monetary benefits may not be the primary benefit for a certain conservation measure. Thus, marketing/ advertising would promote simultaneously the direct and the realistic benefits of ECMs. 


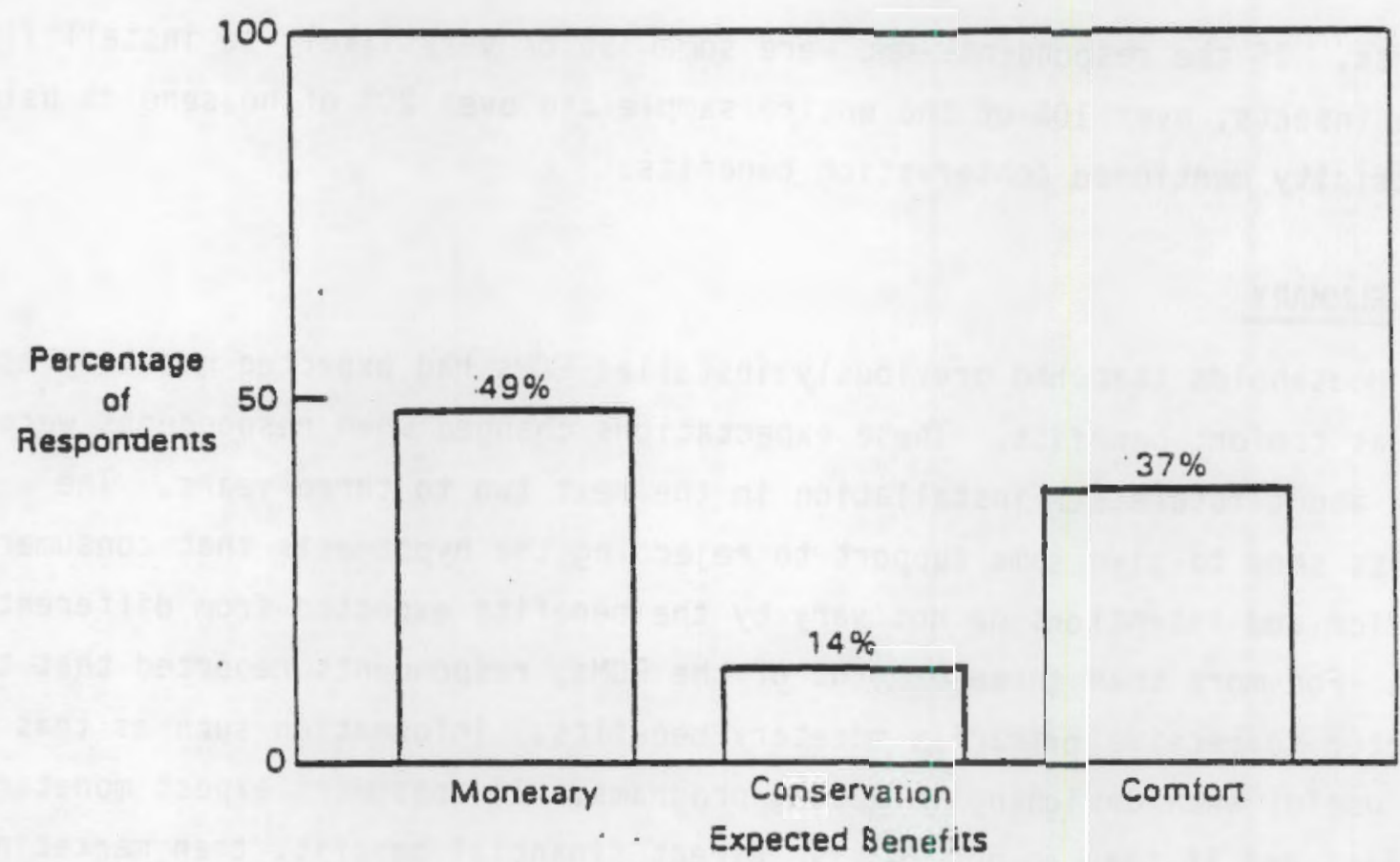

FIGURE 5.1.A. Benefits Expected from Weatherproofing, All Heating Fuels $(n=1127)$

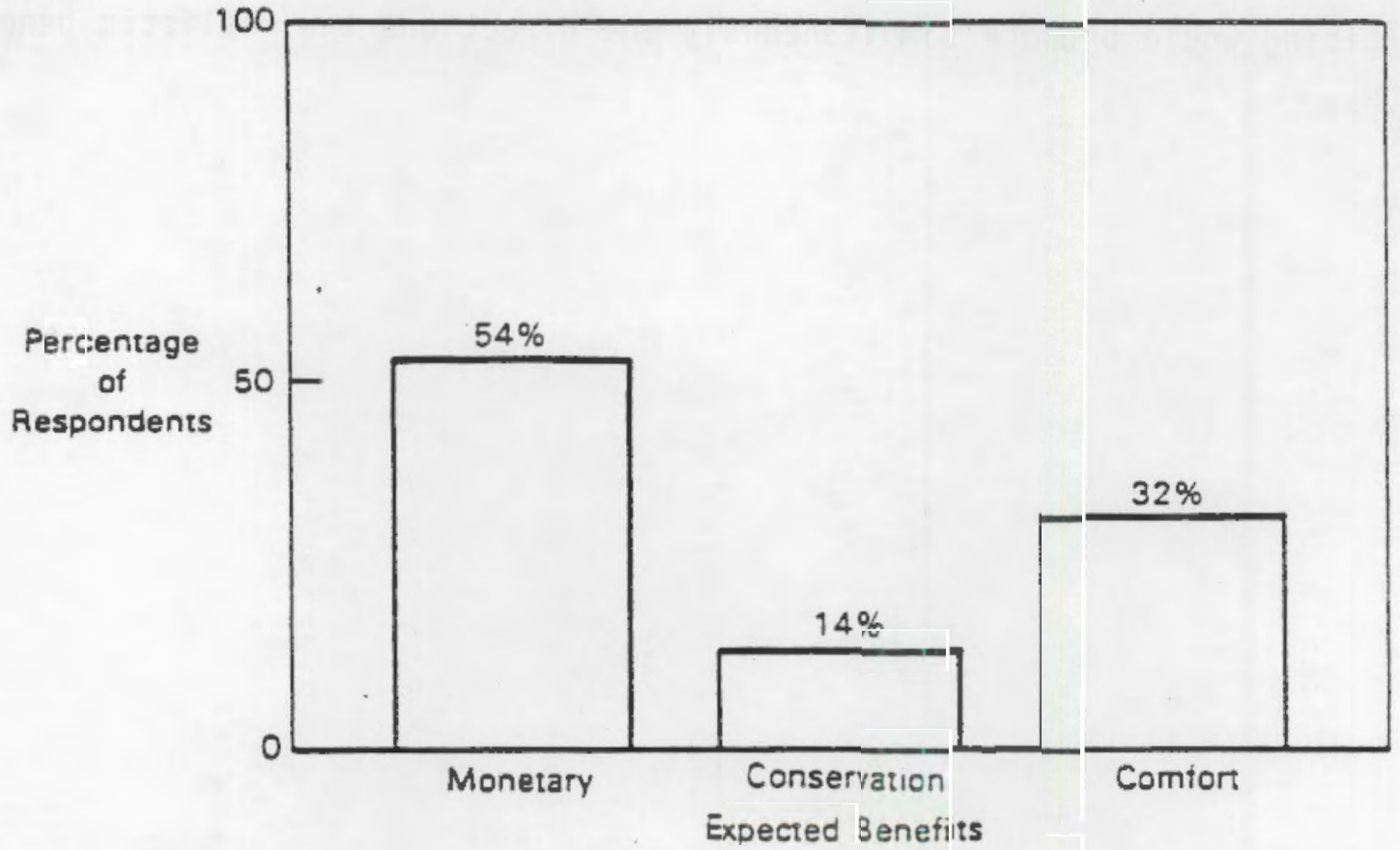

FIGURE 5.1.B. Benefits Expected from Weatherproofing, Heating Fuel Electric $(n=661)$ 


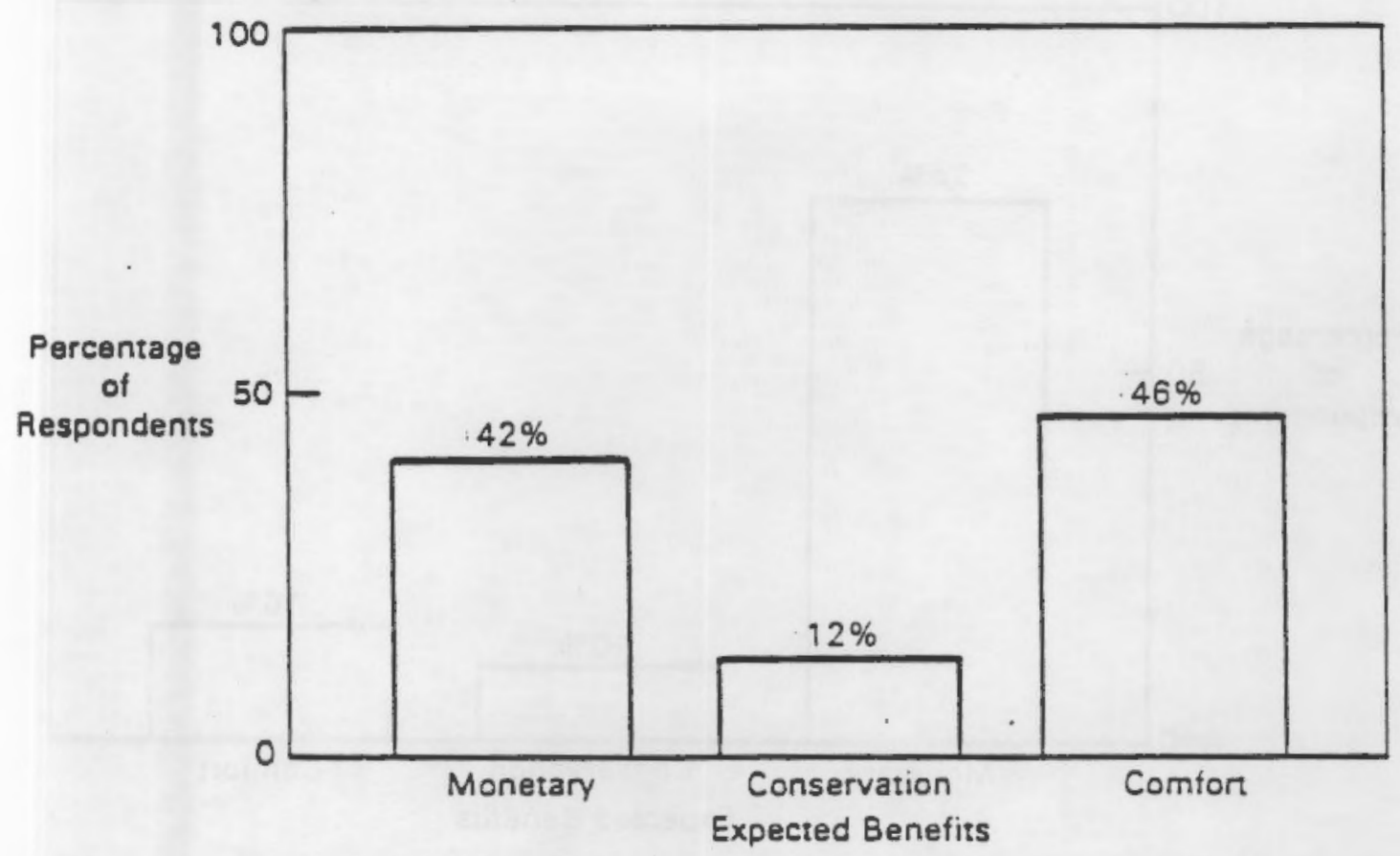

FIGURE 5.2.A. Benefits Expected from Storm Windows, All Heating Fuels ( $n=822$ )

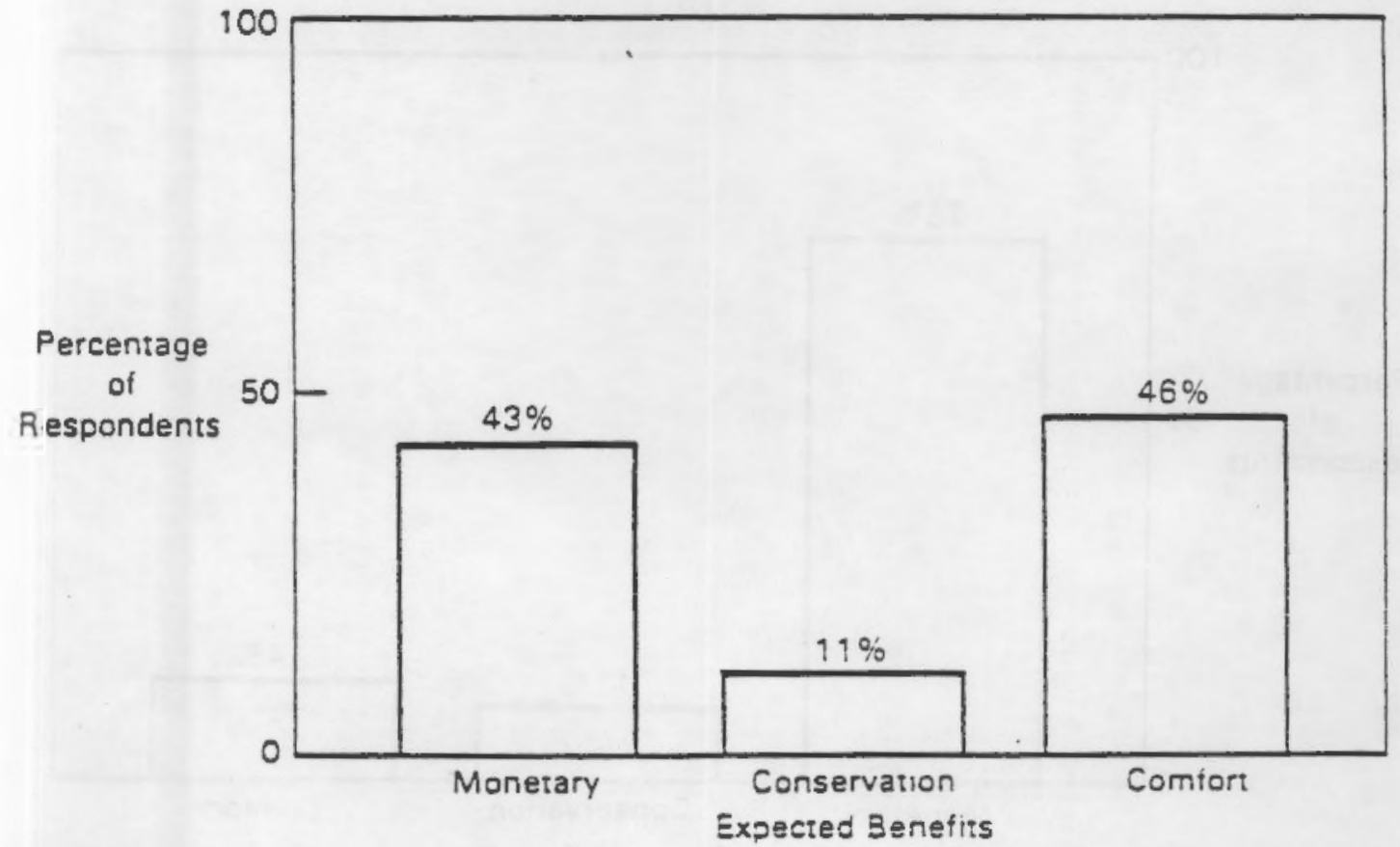

FIGURE 5.2.B. Benefits Expected from Storm Windows, Heating Fuel Electric $(n=469)$ 


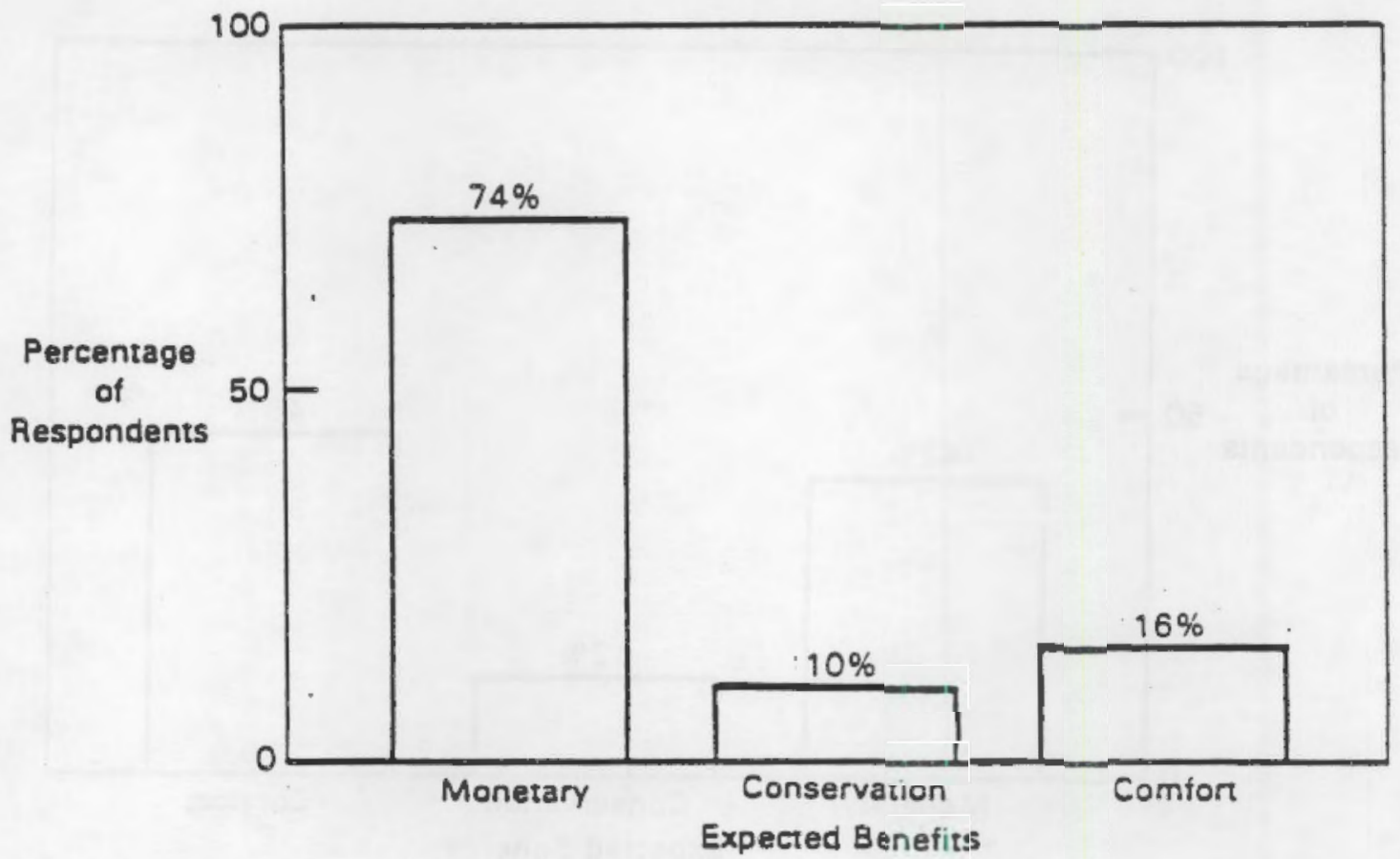

FIGURE 5.3.A. Benefits Expected from Heat Pump/Furnace, All Heating Fuels $(n=95)$

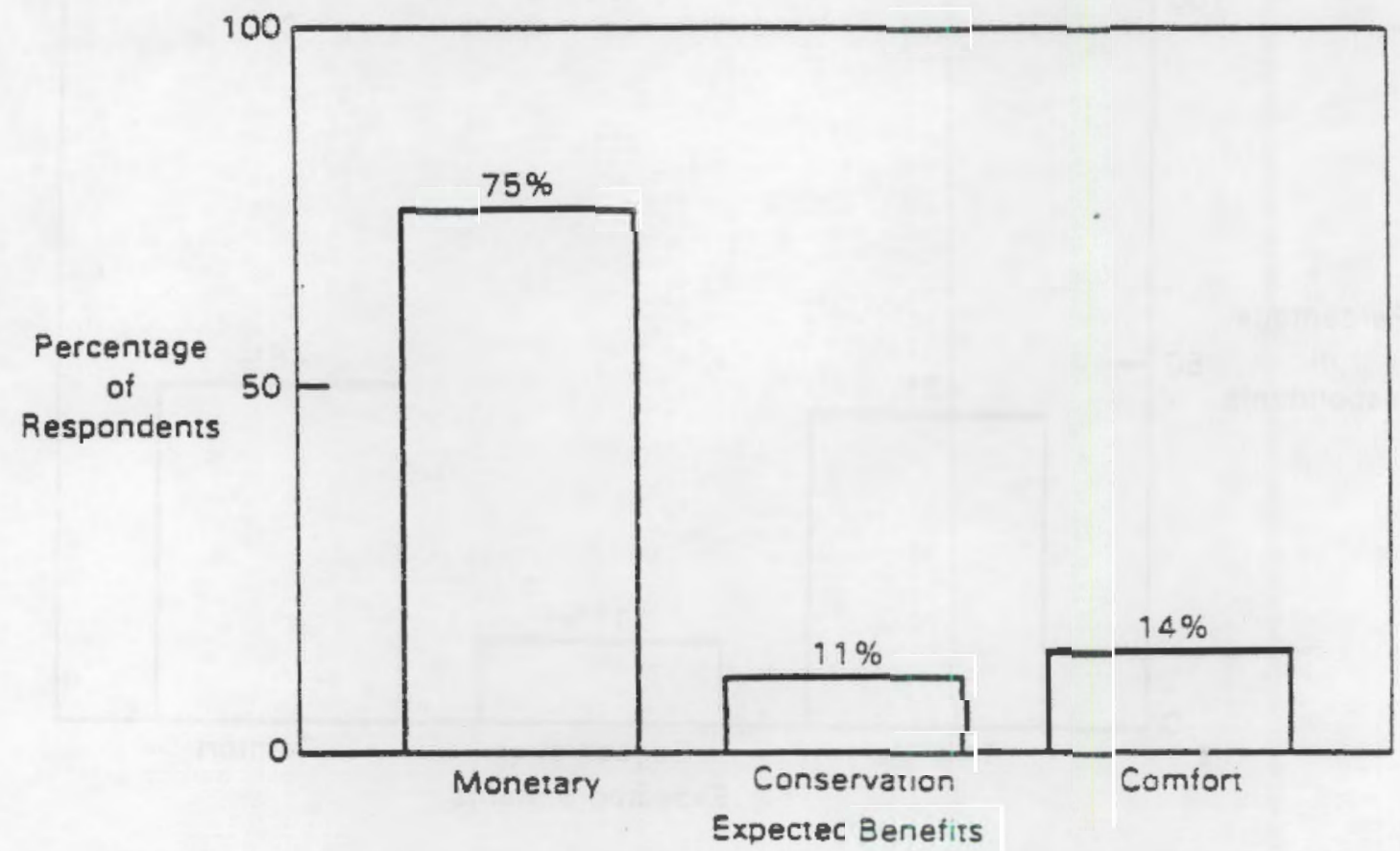

FIGURE 5.3.B. Benefits Expected from Heat Pump/Furnace, Heating Fuel Electric $(n=91)$ 


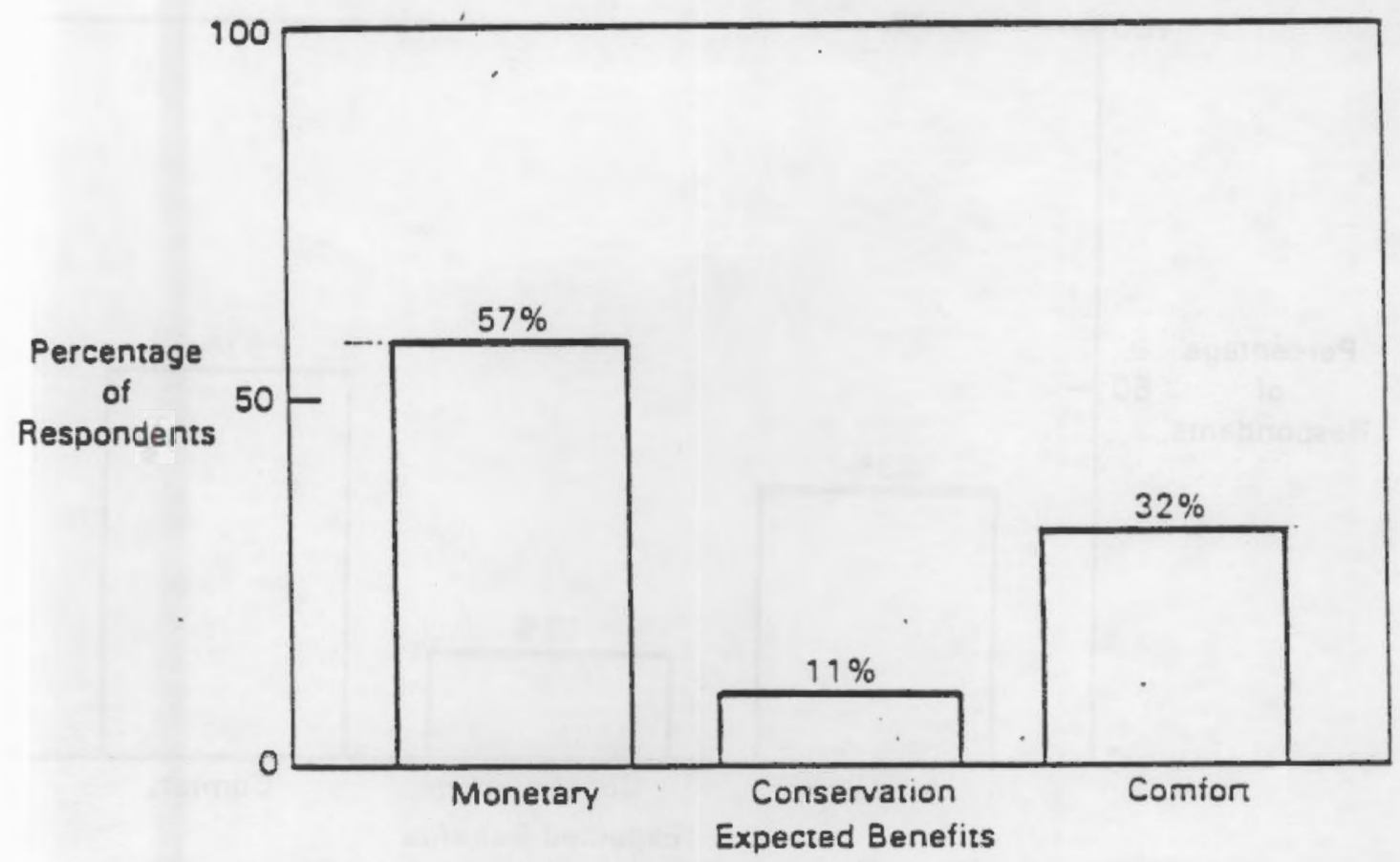

FIGURE 5.4.A. Benefits Expected from Automatic Setback Thermostat, All Heating Fuels $(n=301)$

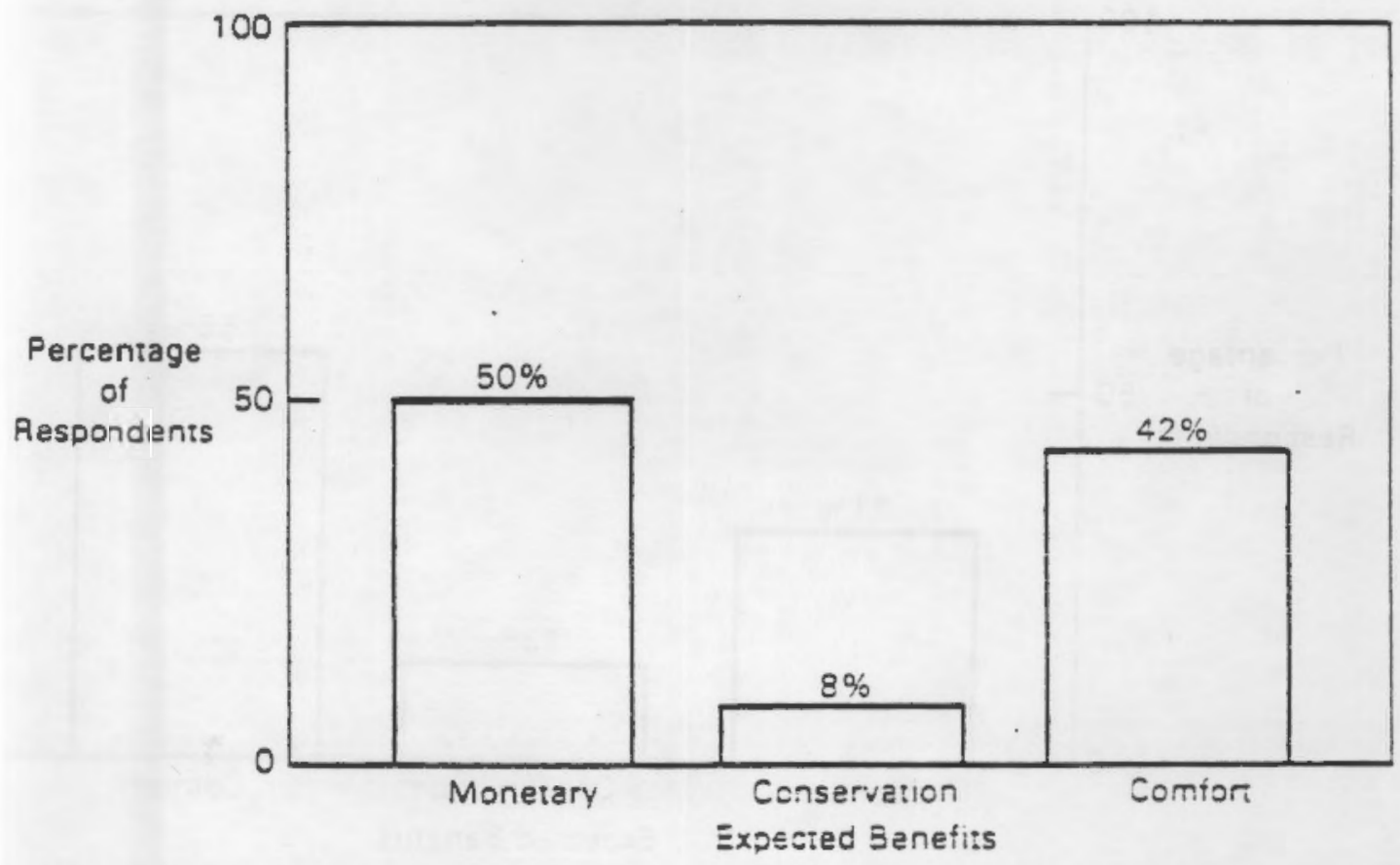

FIGURE 5.4.B. Benefits Expected from Automatic Setback Thermostat, Heating Fuel Electric $(n=157)$ 


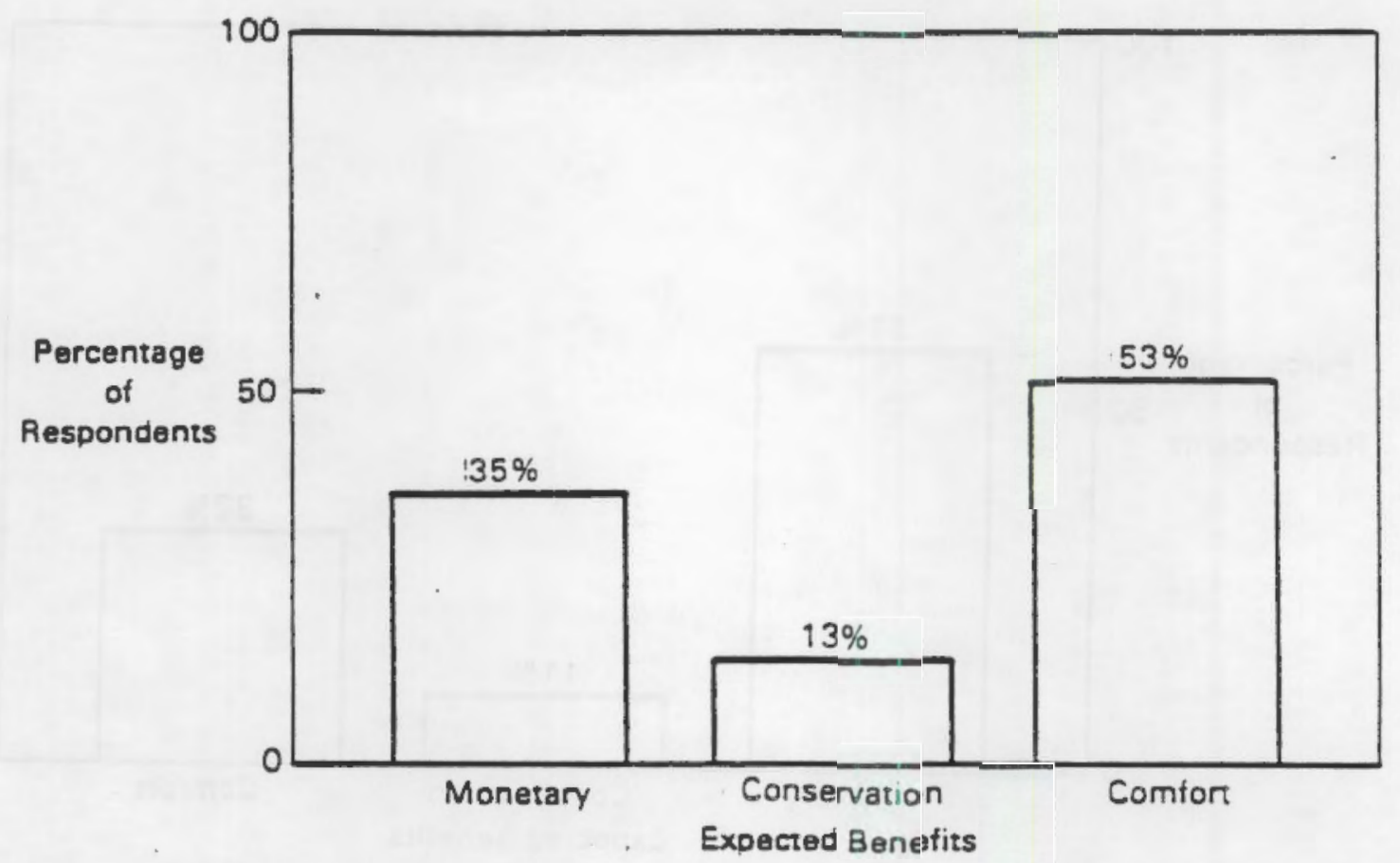

FIGURE 5.5.A. Benefits Expected from Insulated Basement Floor/Crawl Space, All Heating Fuels ( $n=584$ )

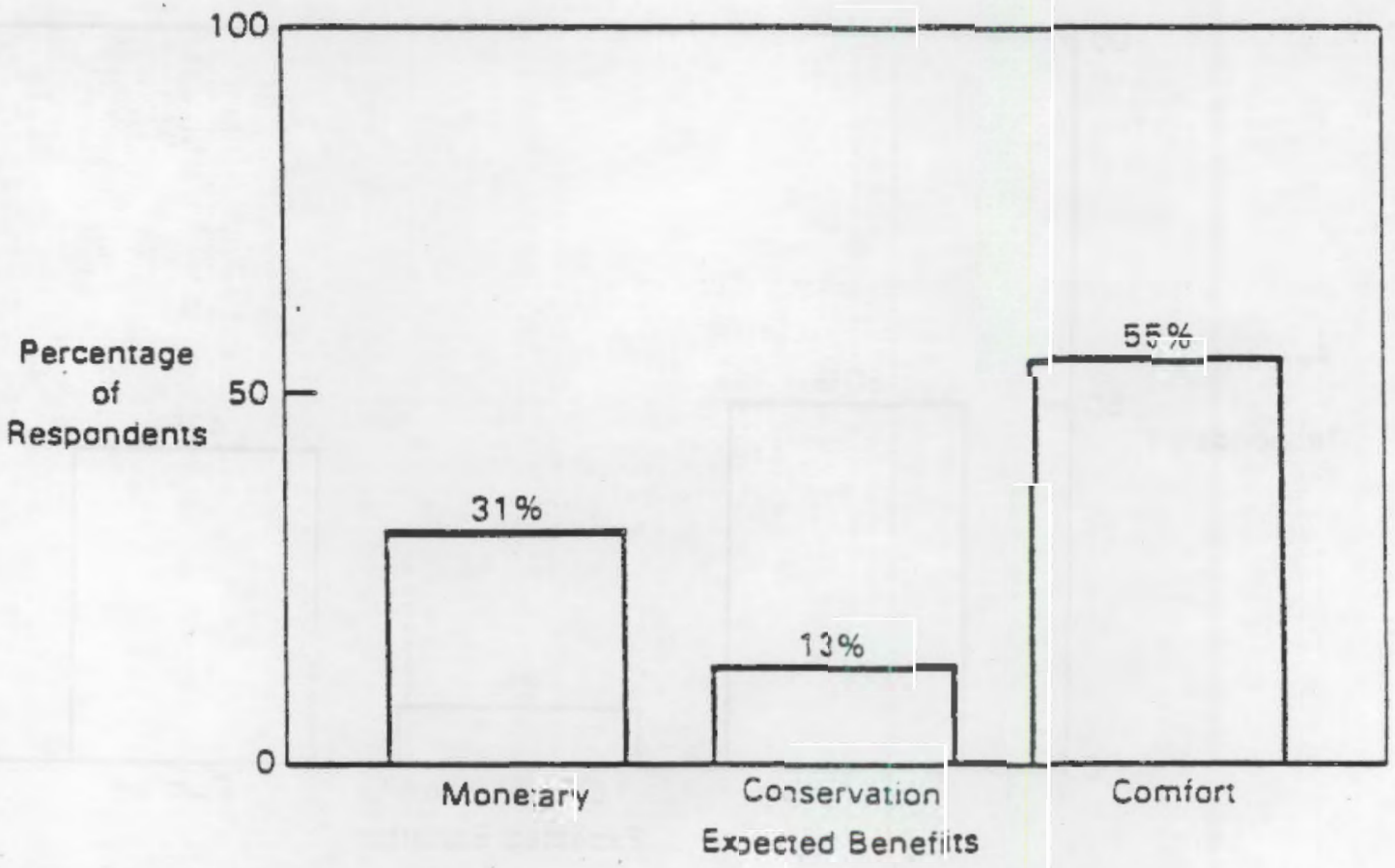

FIGURE 5.5.B. Benefits Expected from Insulated Basement Floor/Crawl Space, Heating Fuel Electric $(n=389)$ 


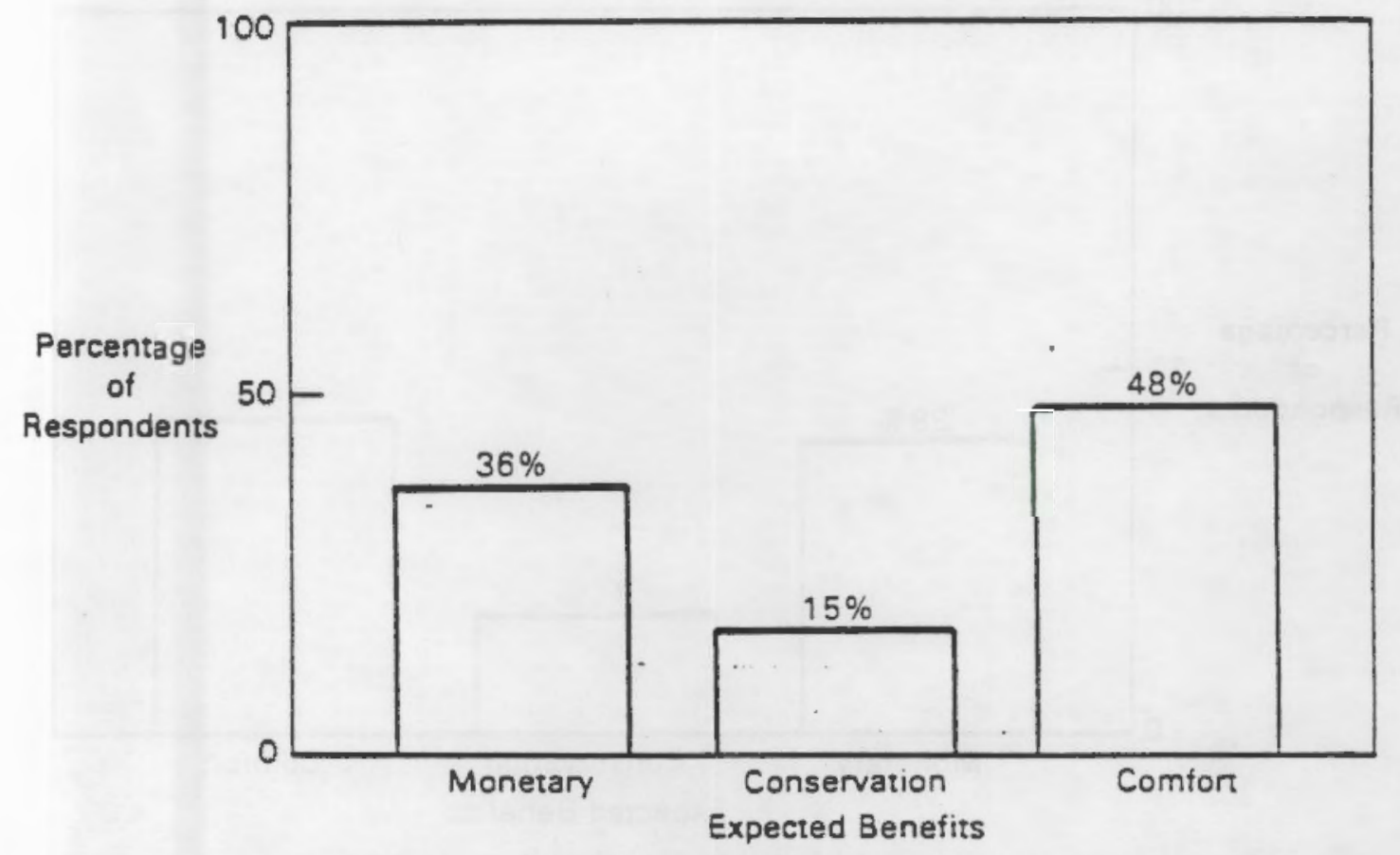

FIGURE 5.6.A. Benefits Expected from Insulated Outside Walls, All Heating Fuels $(n=479)$

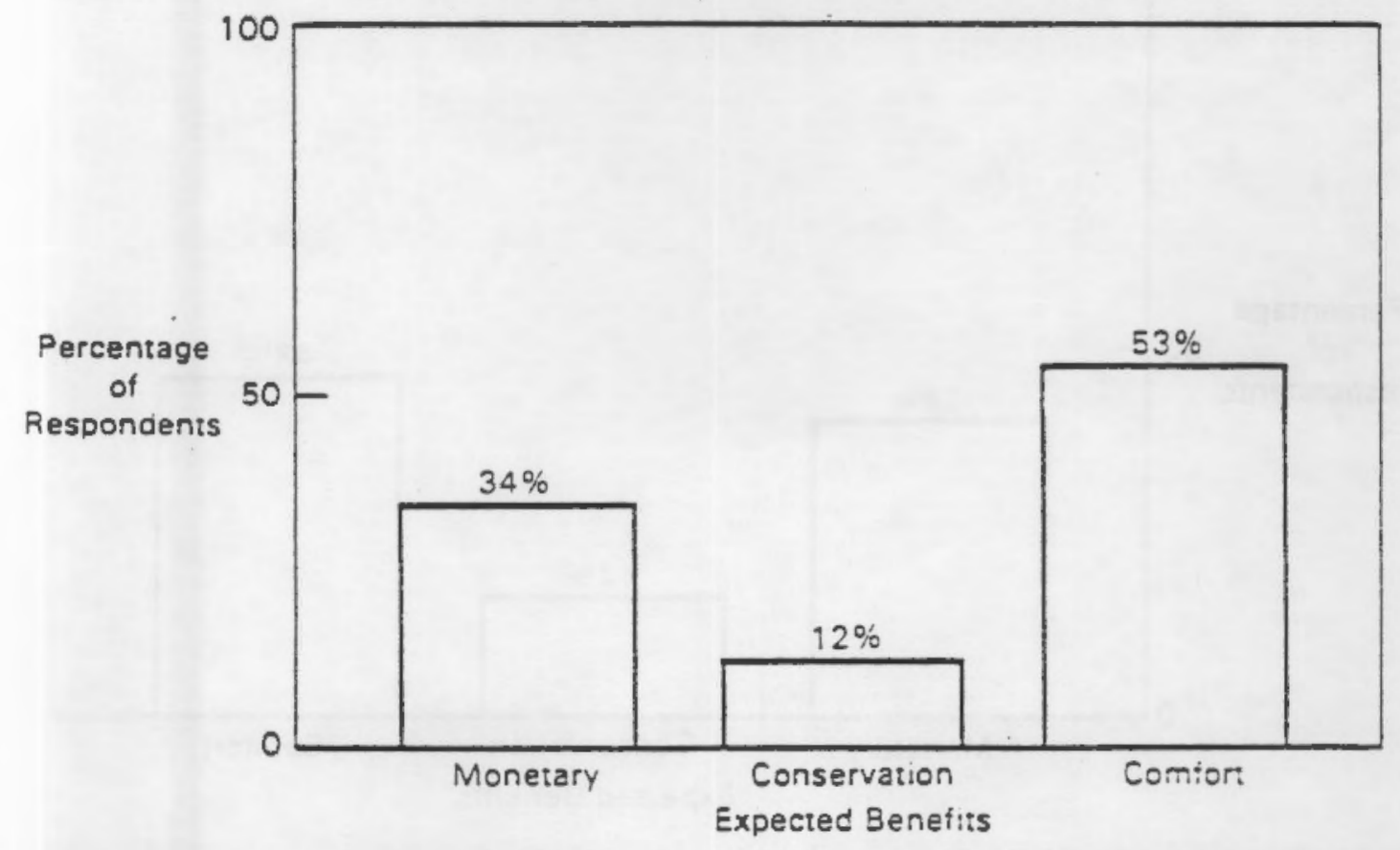

FIGURE 5.6.B. Benefits Expected from Insulated Outside Walls, Heating Fuel Electric $(n=252)$ 


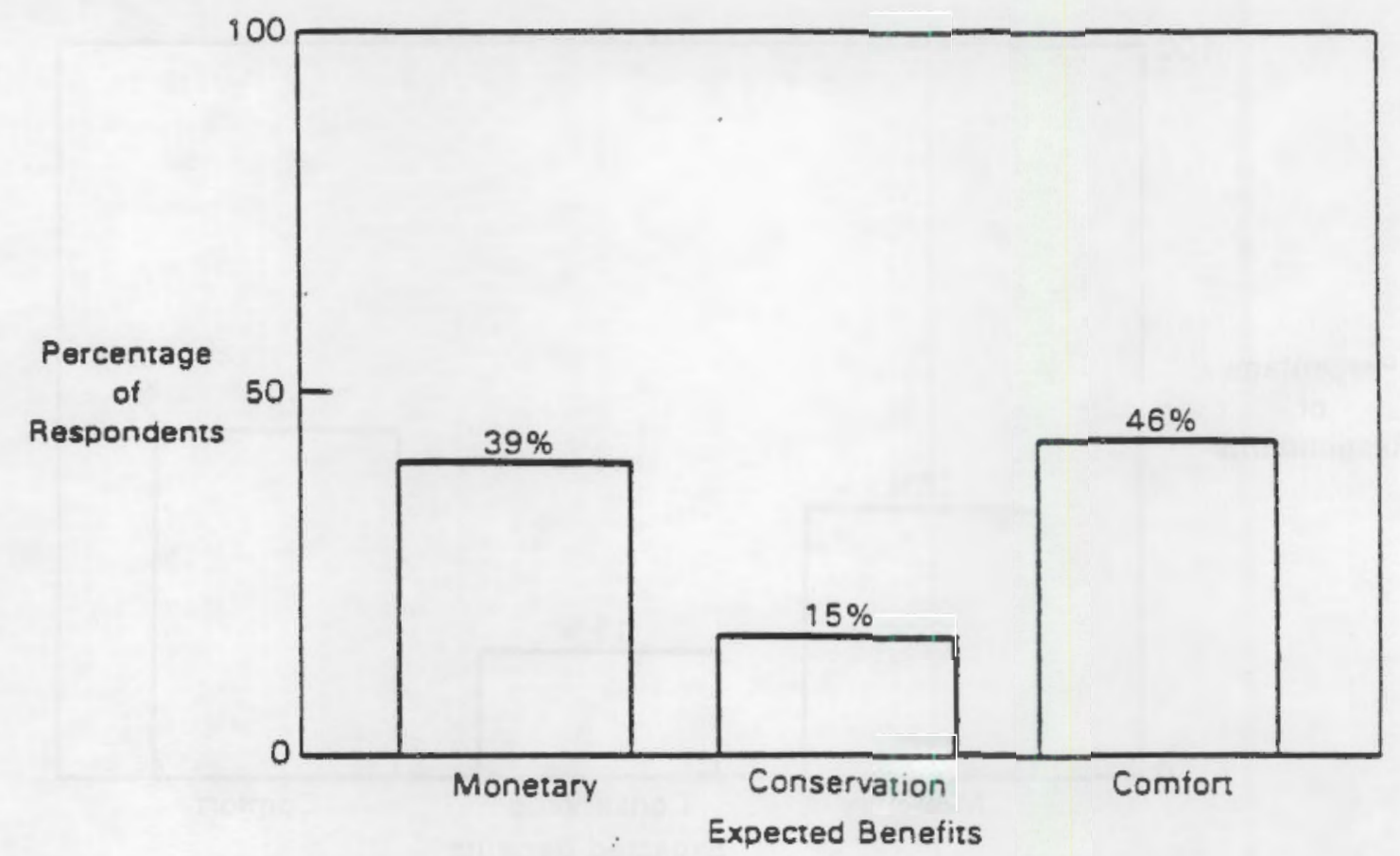

FIGURE 5.7.A. Benefits Expected from Insulated Roof or Attic, All Heating Fuels $(n=814)$

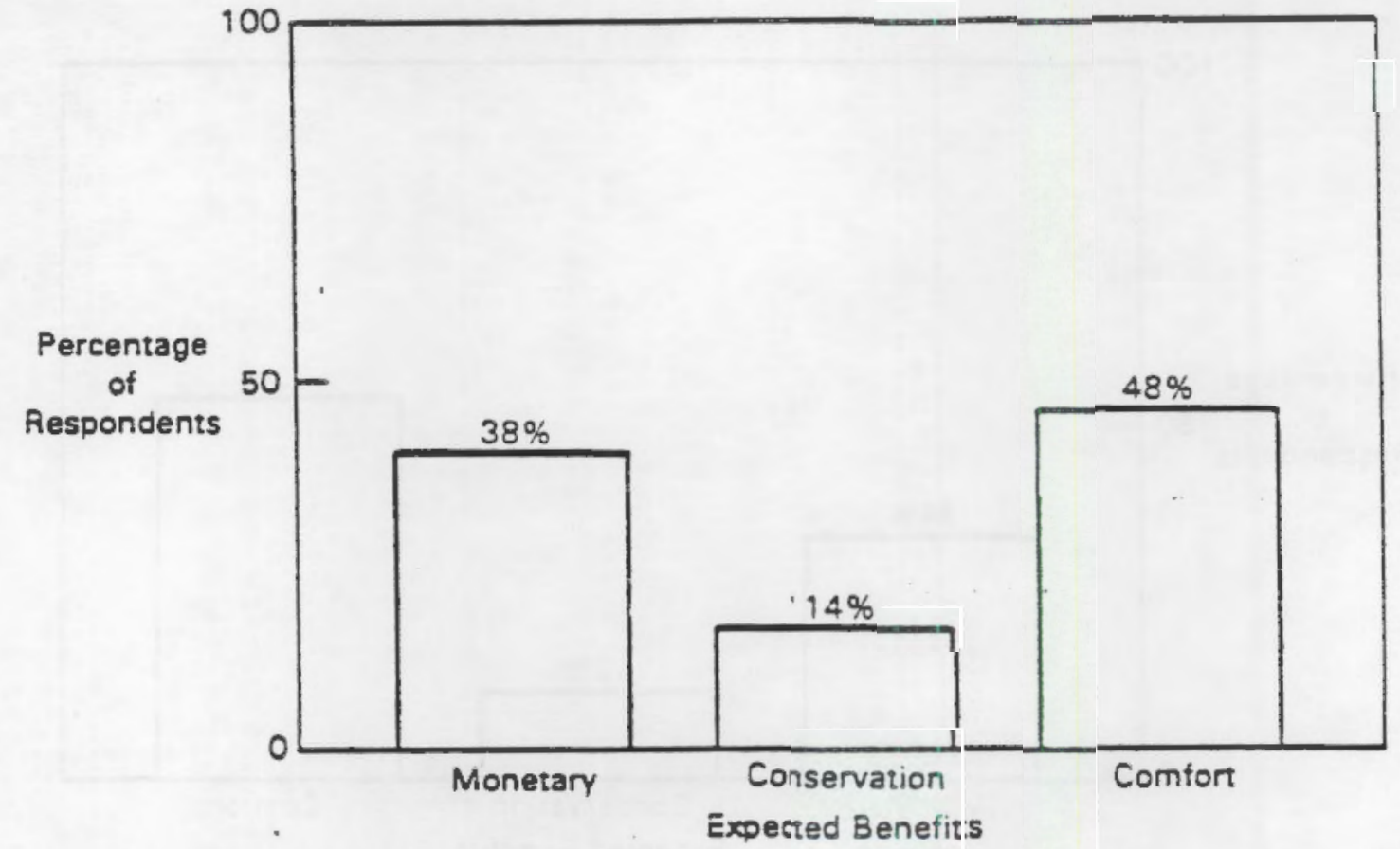

FIGURE 5.7.B. Benefits Expected from Insulated Roof or Attic, Heating Fuel Electric $(n=473)$ 


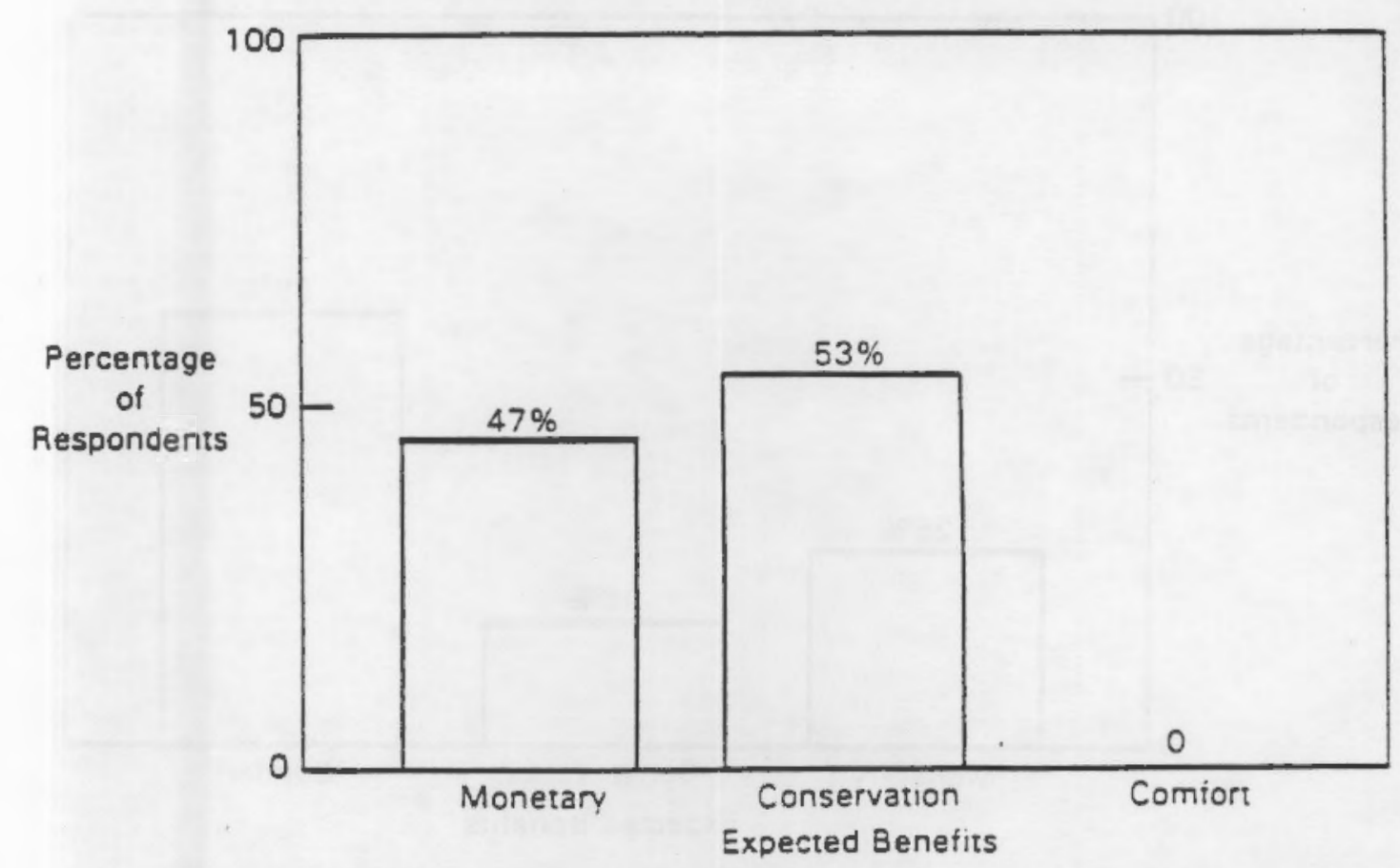

FIGURE 5.8.A. Benefits Expected from Solar Panels, All Heating Fuels $(n=32)$

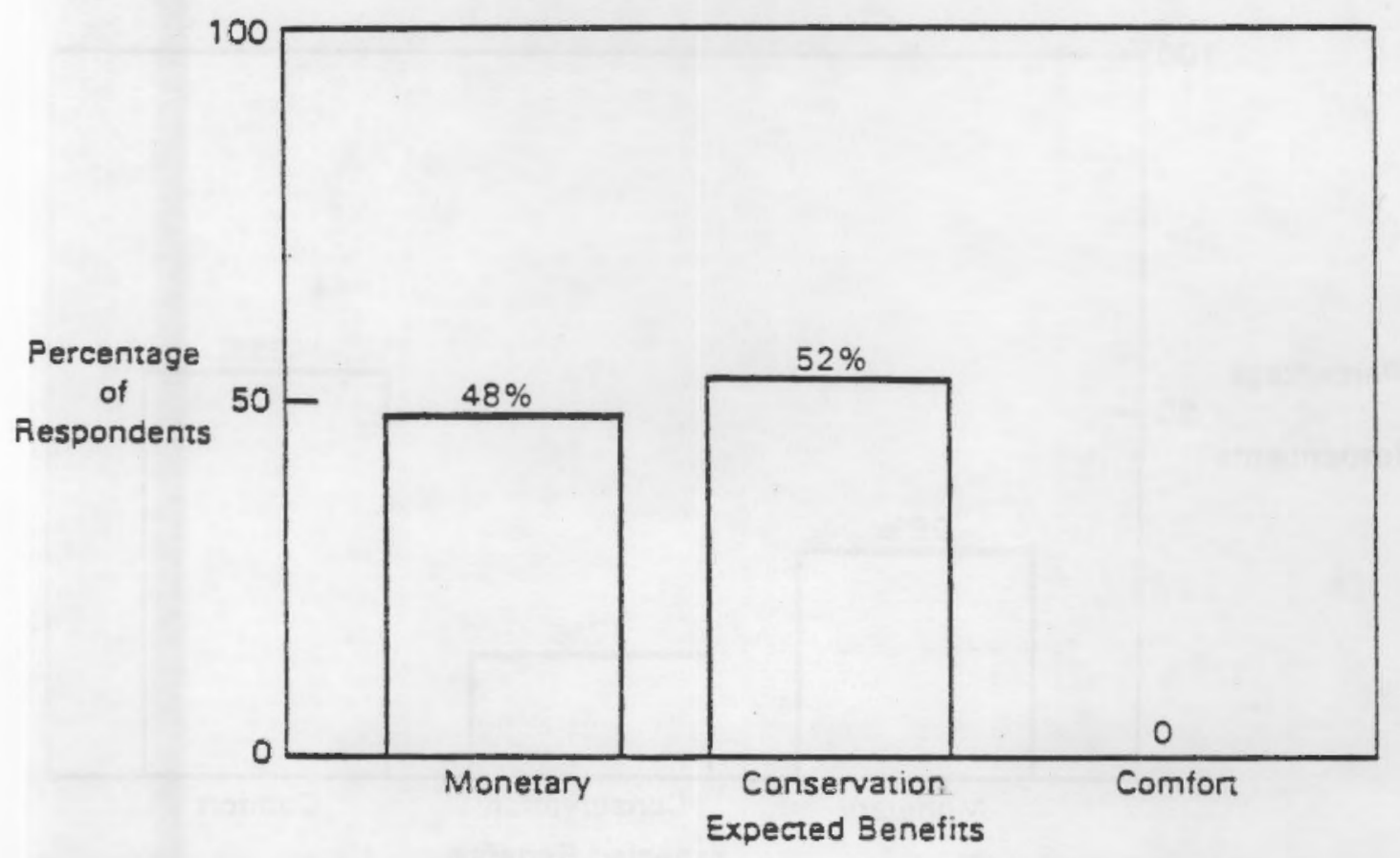

FIGURE 5.8.B. Benefits Expected from Solar Panels, Heating Fuel Electric $(n=24)$ 


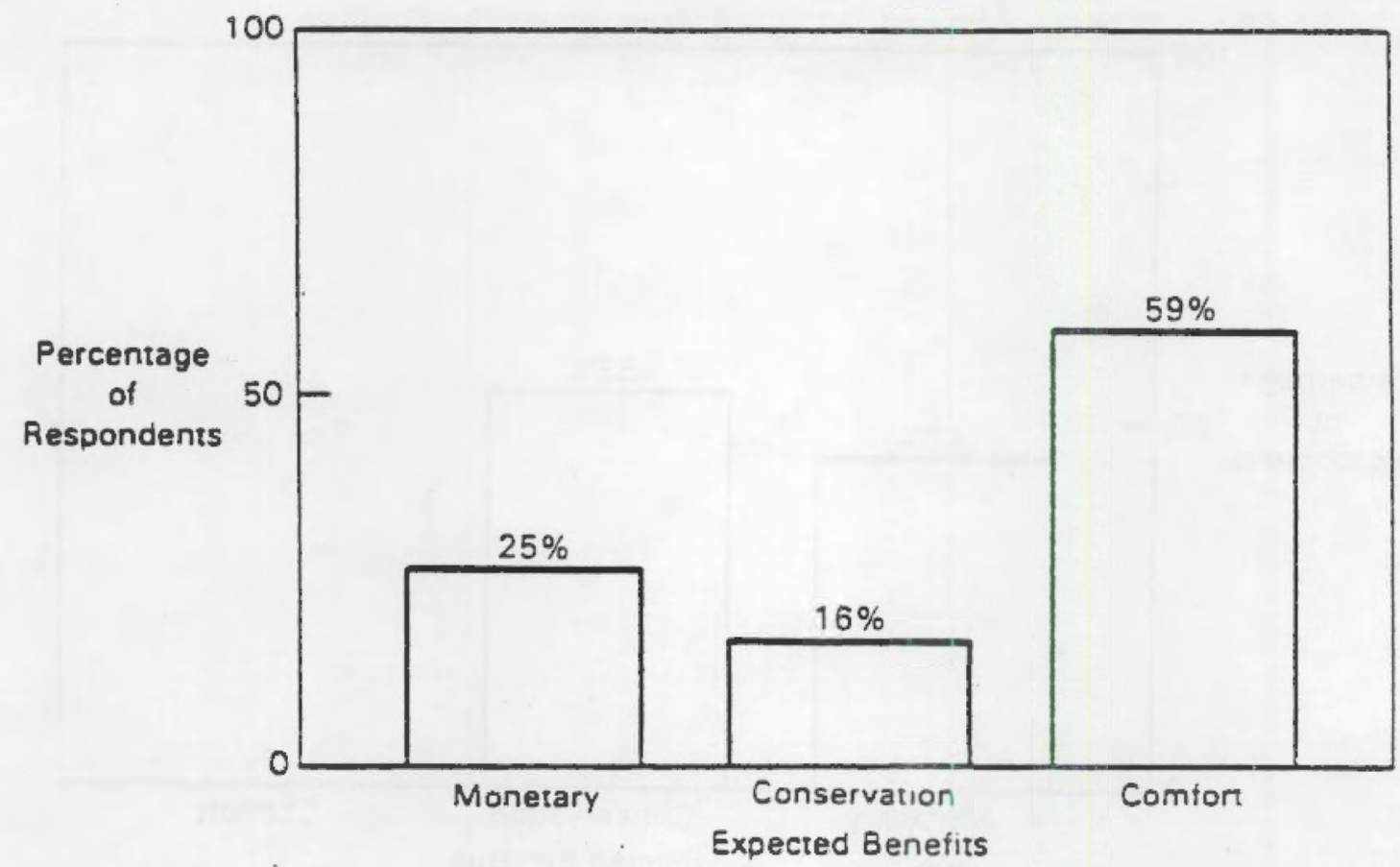

FIGURE 5.9.A. Benefits Expected from Storm or Insulated Doors, All Heating Fuels $(n=629)$

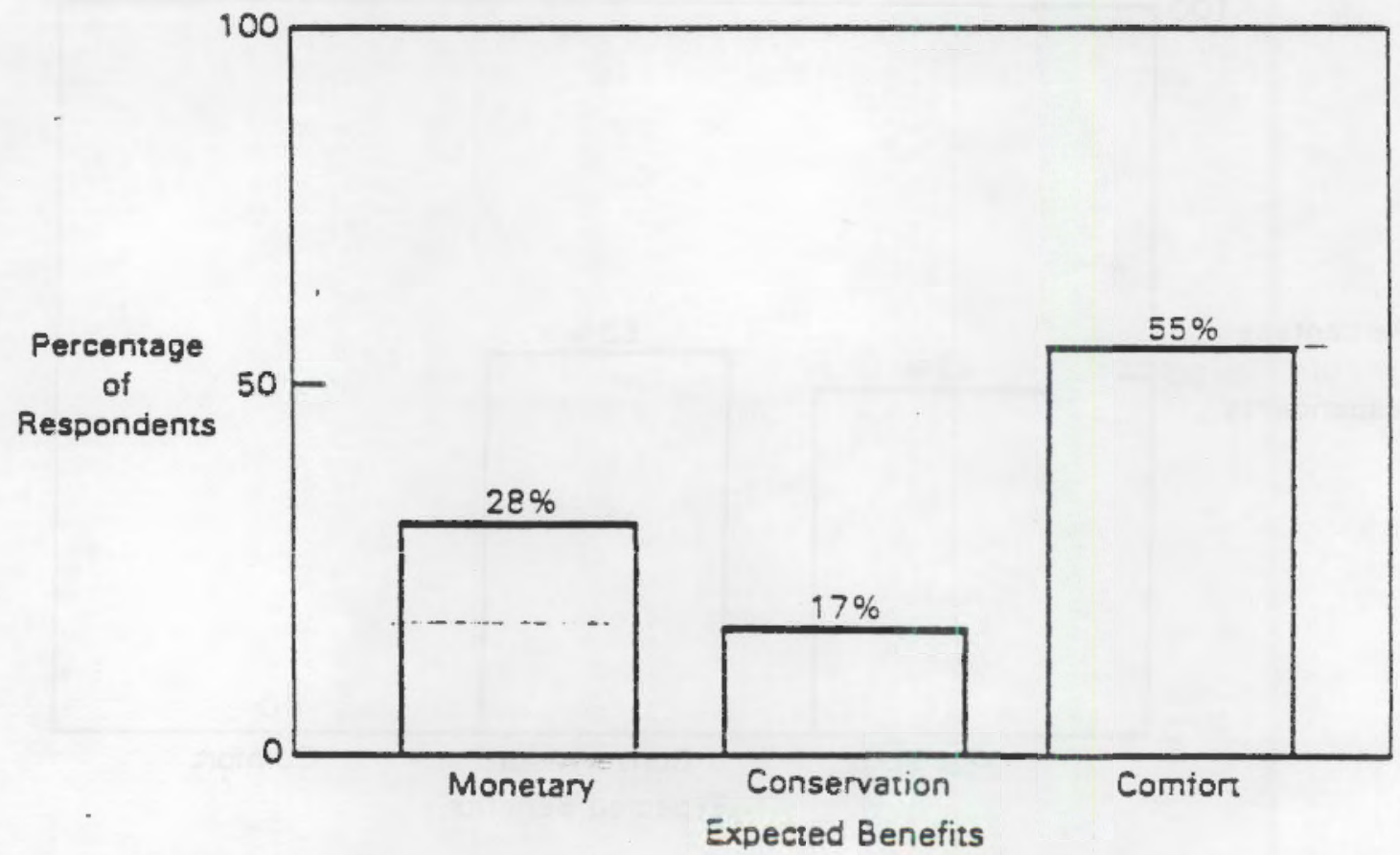

FIGURE 5.9.B. Benefits Expected from Storm or Insulated Doors, Heating Fuel Electric $(n=350)$ 


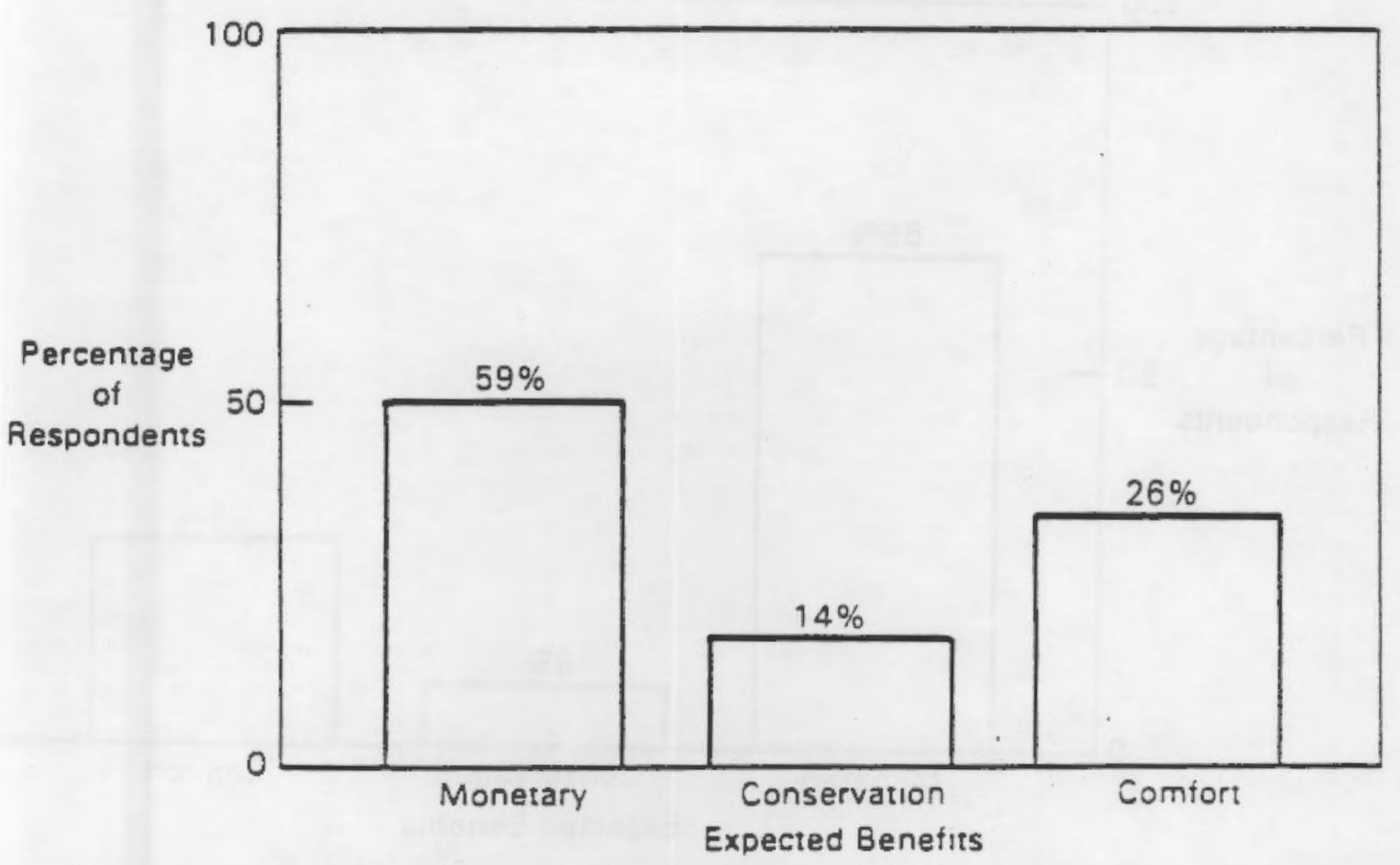

FIGURE 5.10.A. Benefits Expected from Heat Pump Water Heaters, All Heating Fuels $(n=14)$

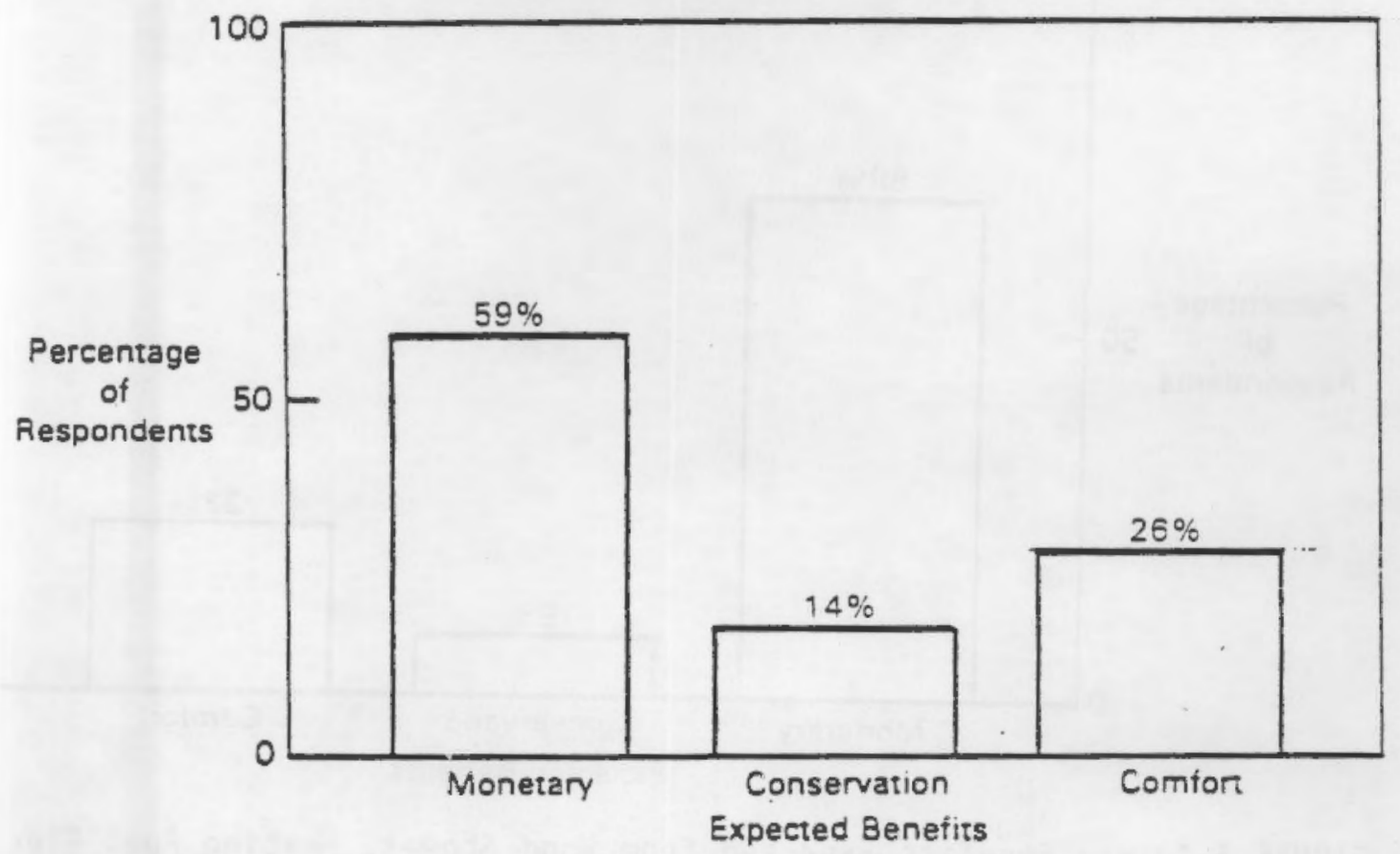

FIGURE 5.10.8. Benefits Expected from Heat Pump Water Heaters, Heating Fuel Electric $(n=14)$ 


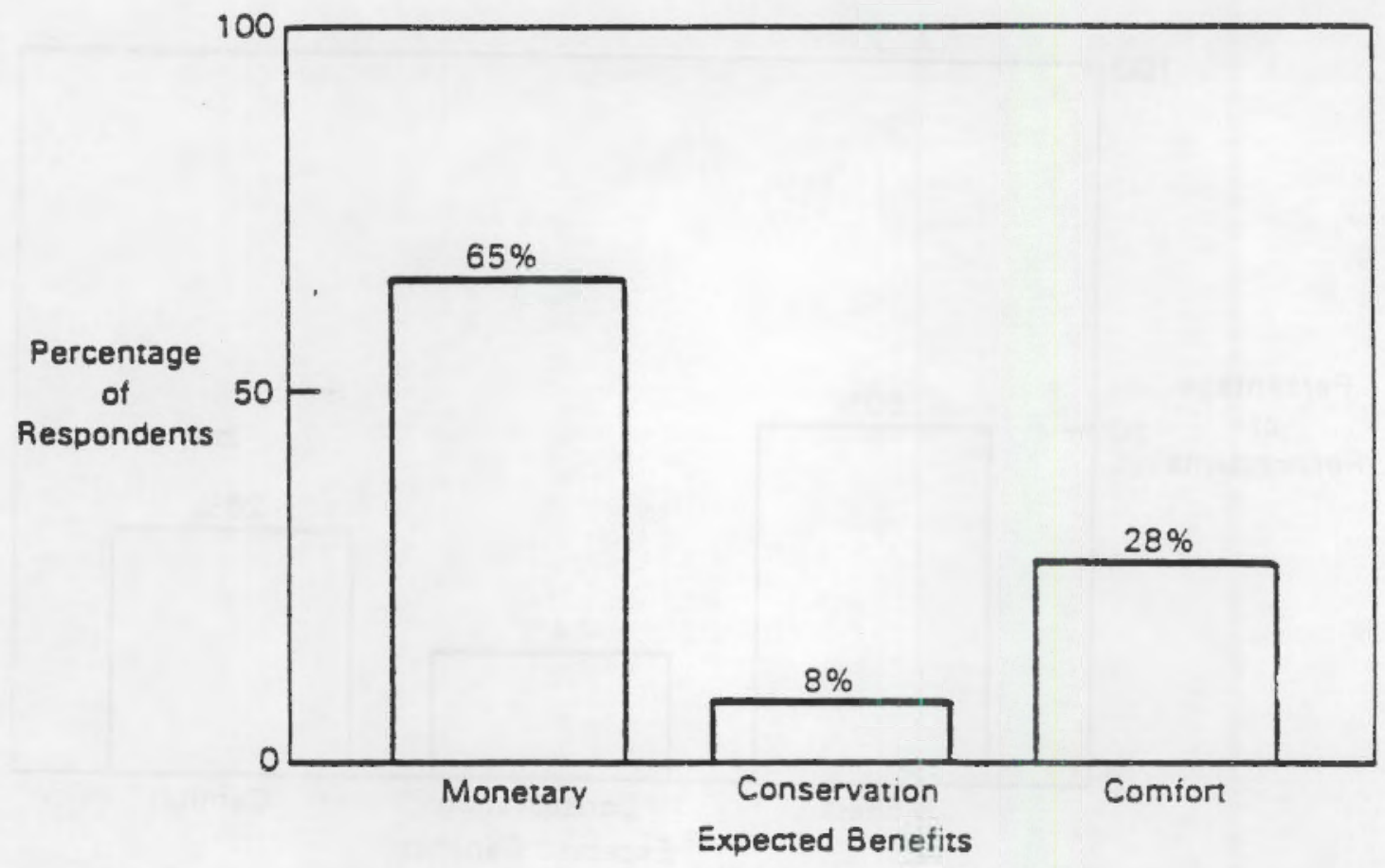

FIGURE 5.11.A. Benefits Expected from Wood Stoves, All Heating Fuels ( $n=594$ )

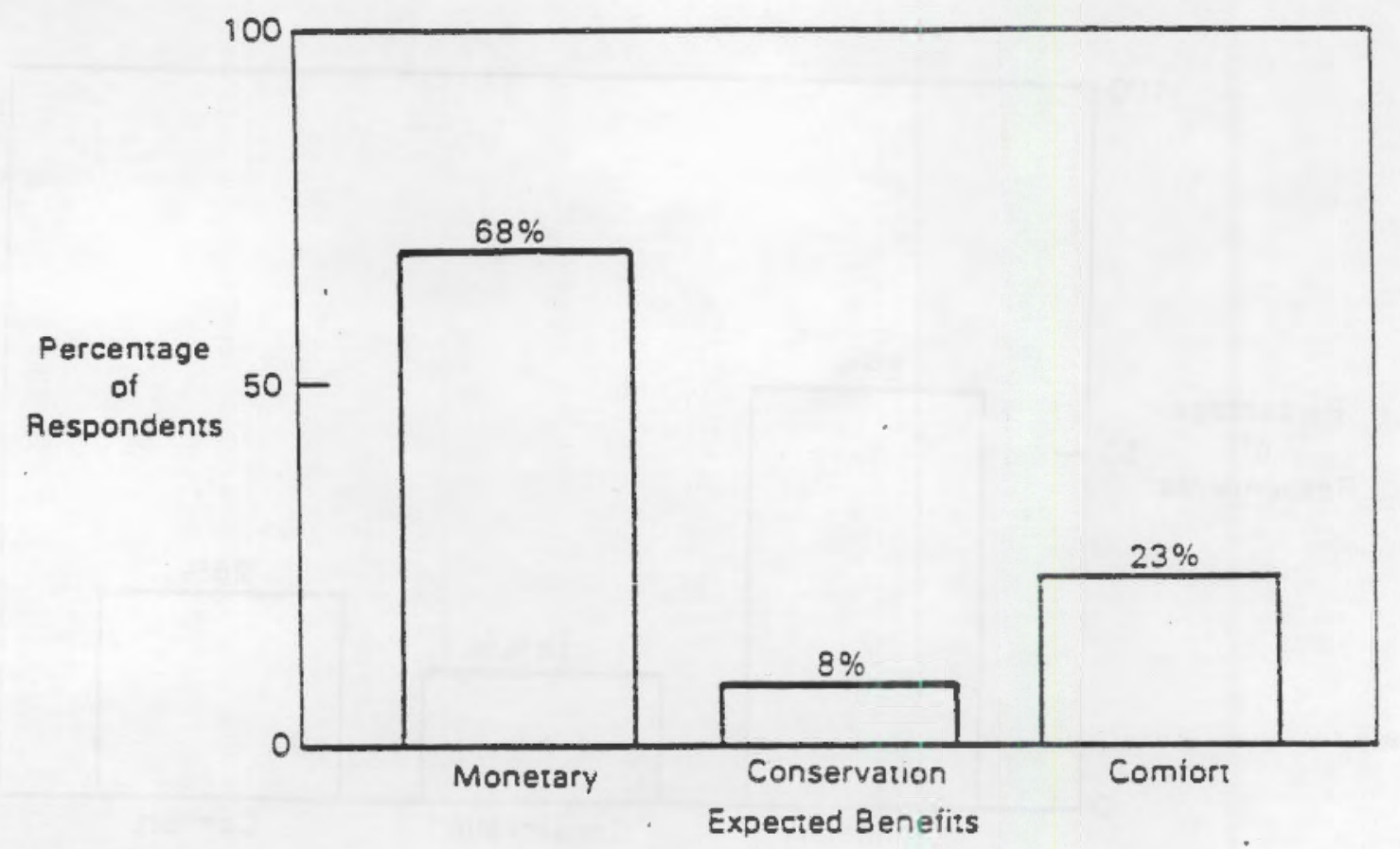

FIGURE 5.11.B. Benefits Expected from Wood Stoves, Heating Fuel Electric $(n=319)$ 


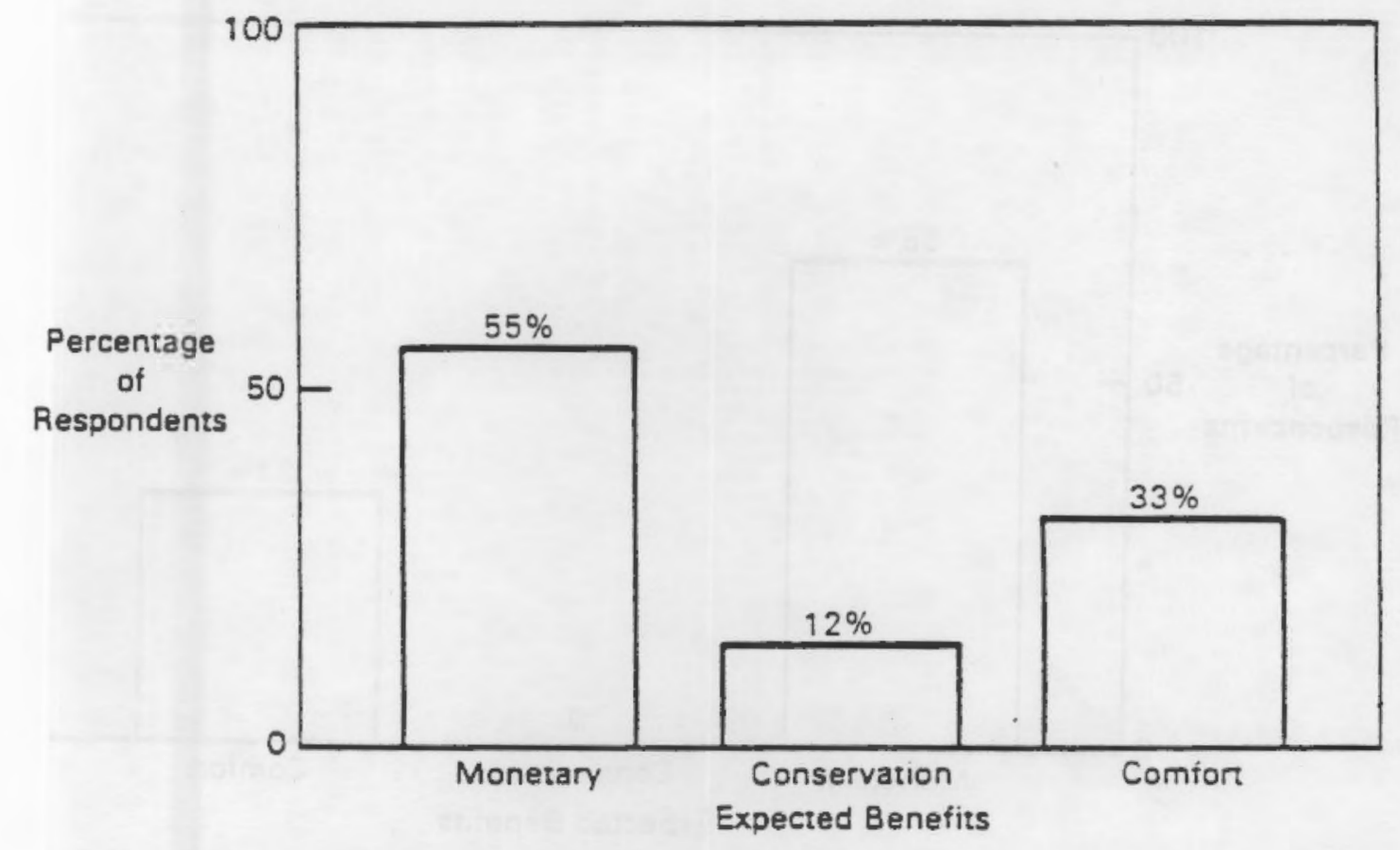

FIGURE 5.12.A. Benefits Expected from Fireplace Inserts, All Heating Fuels $(n=311)$

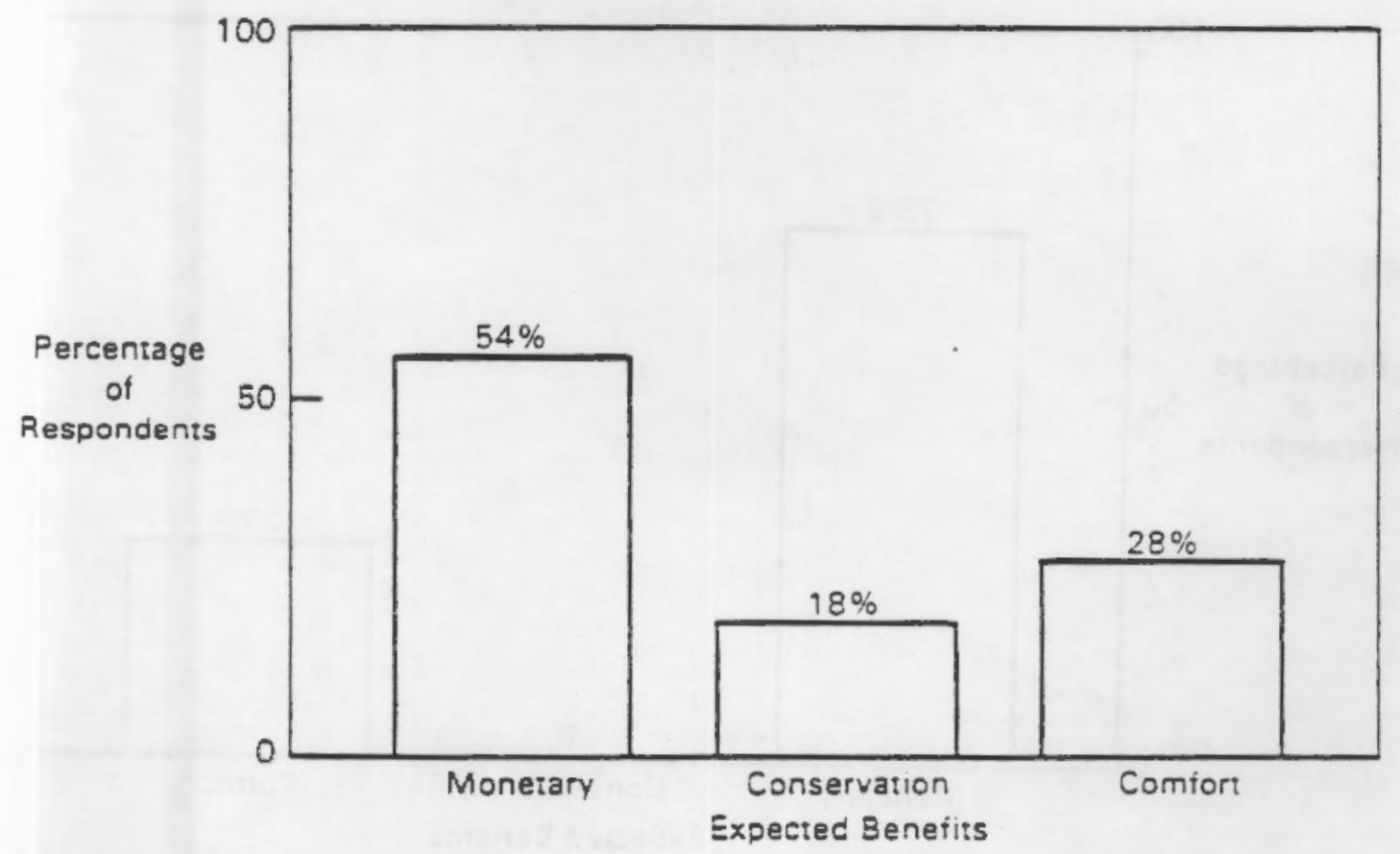

FIGURE 5.12.B. Benefits Expected from Fireplace Inserts, Heating Fuel Electric $(n=179)$ 


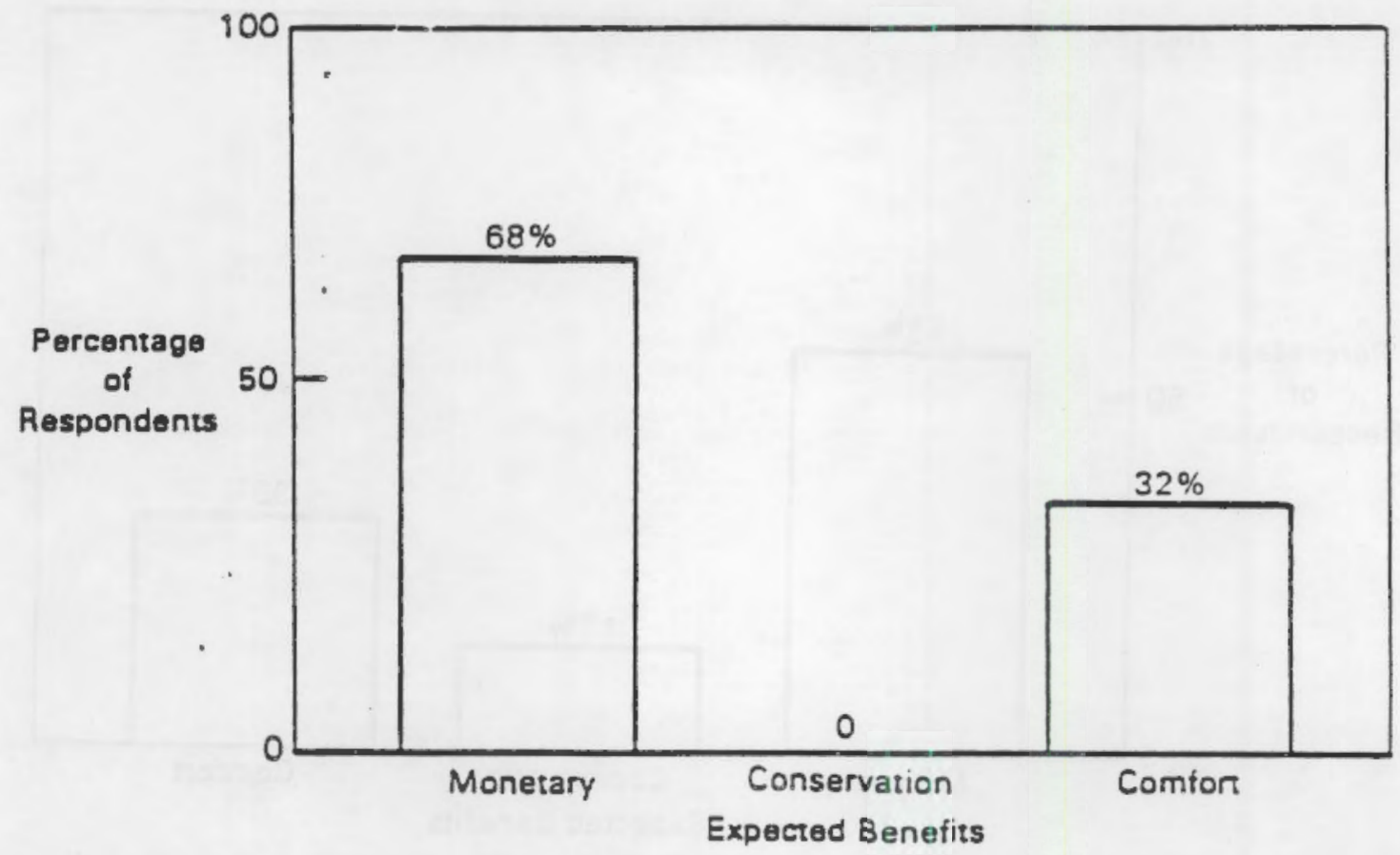

FIGURE 5.13.A. Benefits Expected by Homeowners Who Are Somewhat or Very Likely to Install Weatherproofing, All Heating Fuels ( $n=145)$

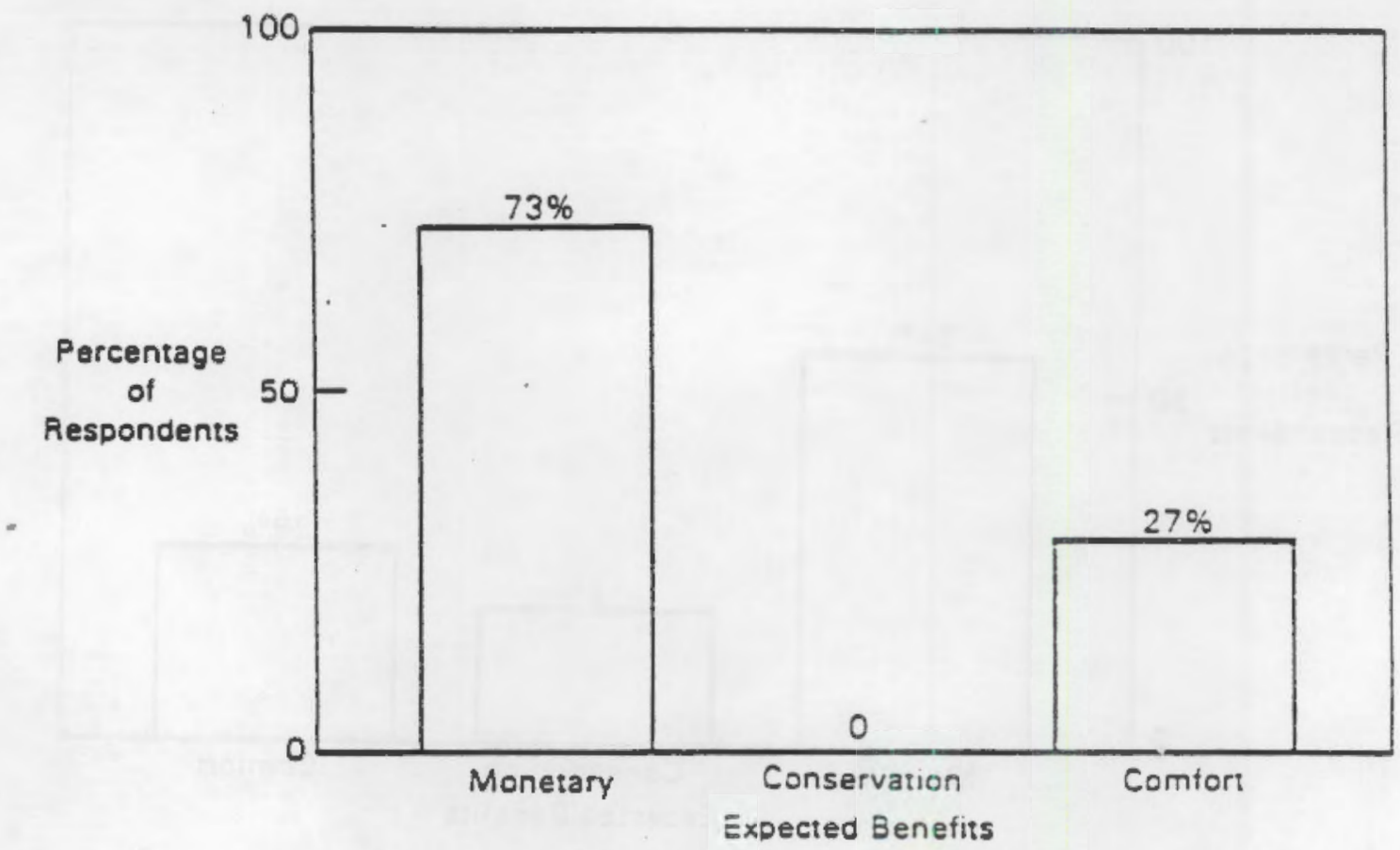

FIGURE 5.13.8. Benefits Expected by Homeowners Who Are Somewhat or Very Likely to Install Weatherproofing, Heating Fuel Electric $(n=77)$ 


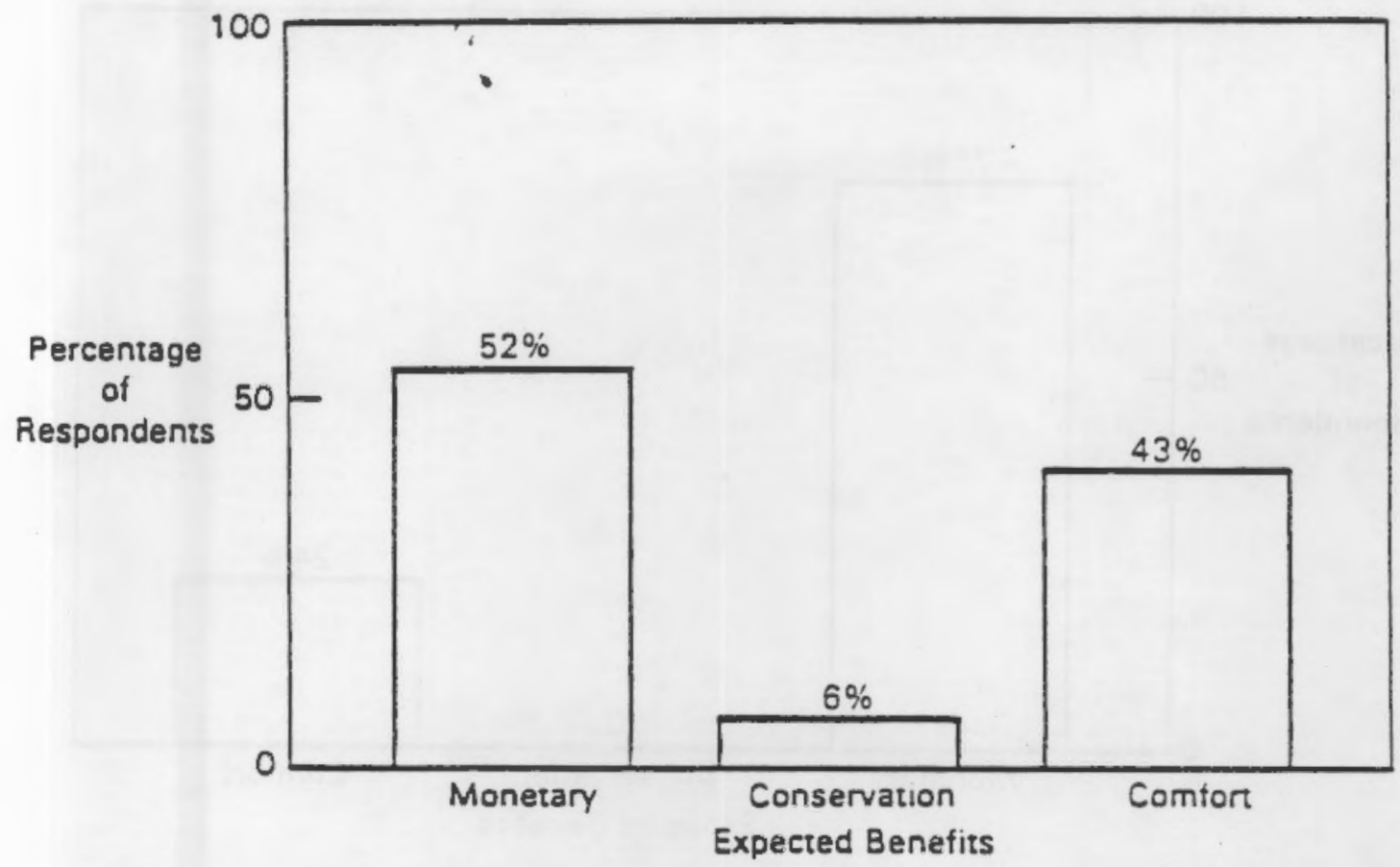

FIGURE 5.14.A. Benefits Expected by Homeowners who Are Somewhat or Very Likely to Install Storm Windows, All Heating Fuels ( $n=168$ )

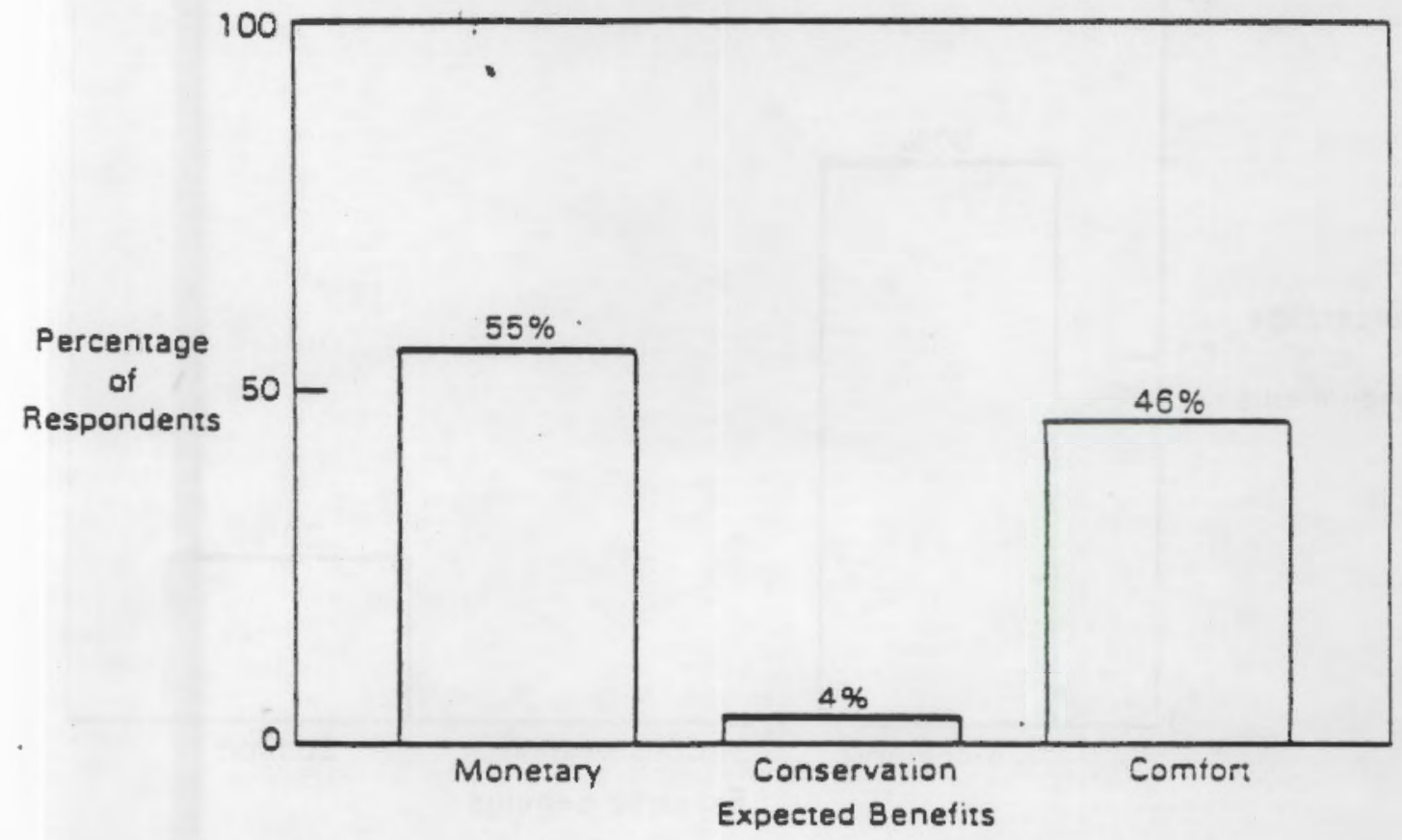

FIGURE 5.14.B. Benefits Expected by Homeowners who Are Somewhat or Very Likely to Install Storm Windows $(n=73)$ 


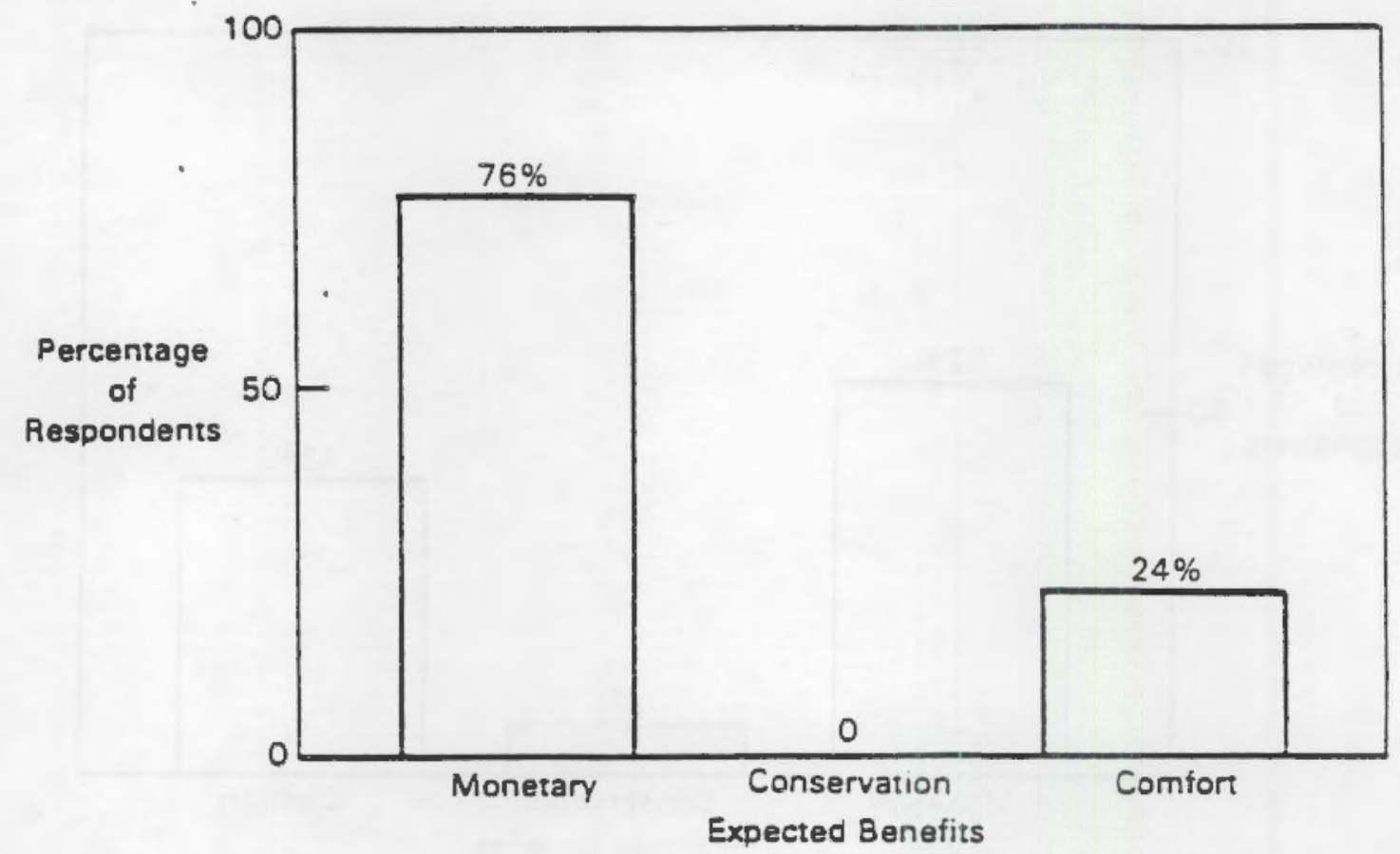

FIGURE 5.15.A. Benefits Expected by Homeowners Who Are Somewhat or Very Likely to Install a Heat Pump/Furnace, All Heating Fuels ( $n=125$ )

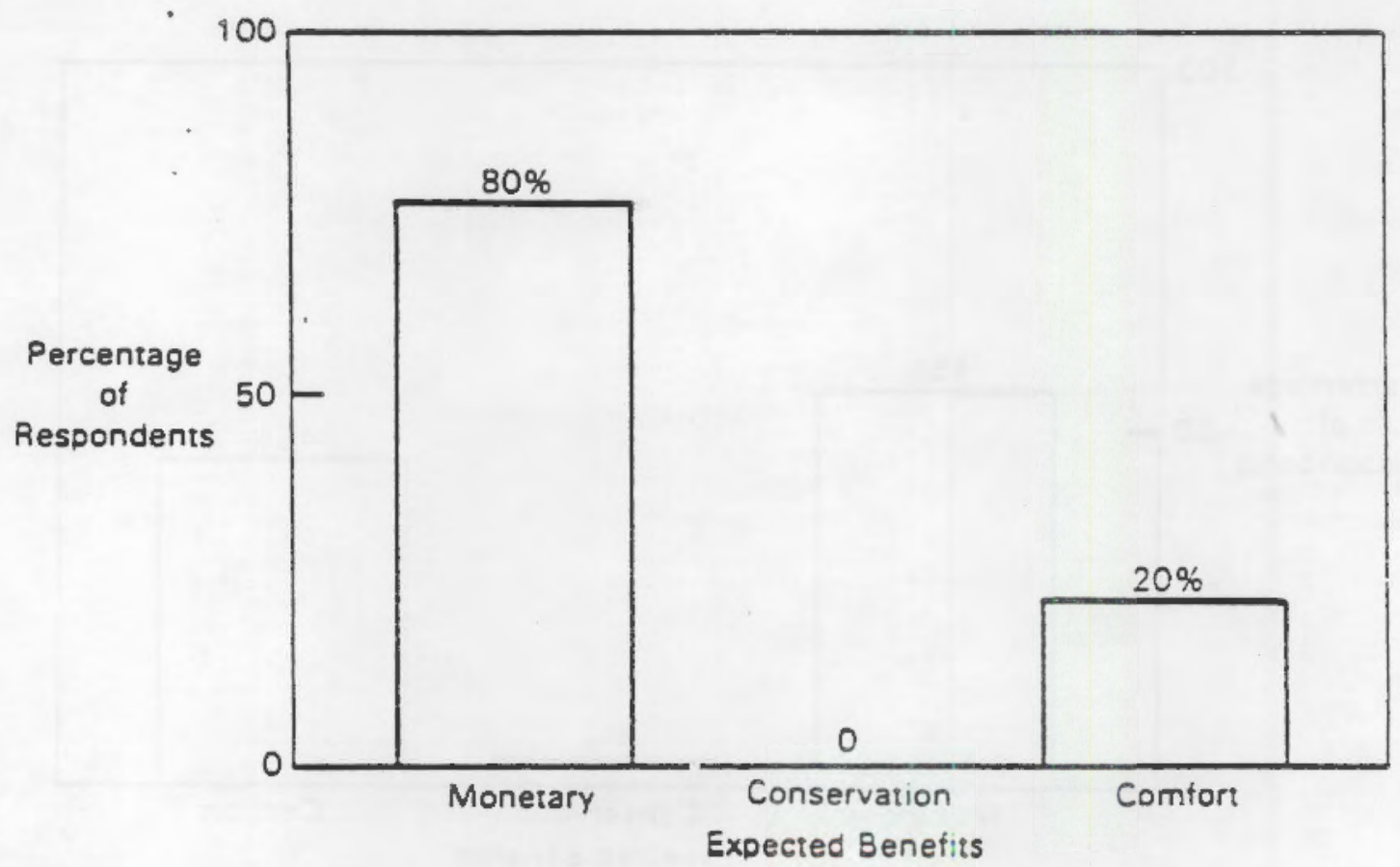

FIGURE 5.15.B. Benefits Expected by Homeowners Who Are Somewhat or Very Likely to Install a Heat Pump/Furnace, Heating Fuel Electric $(n=74)$ 


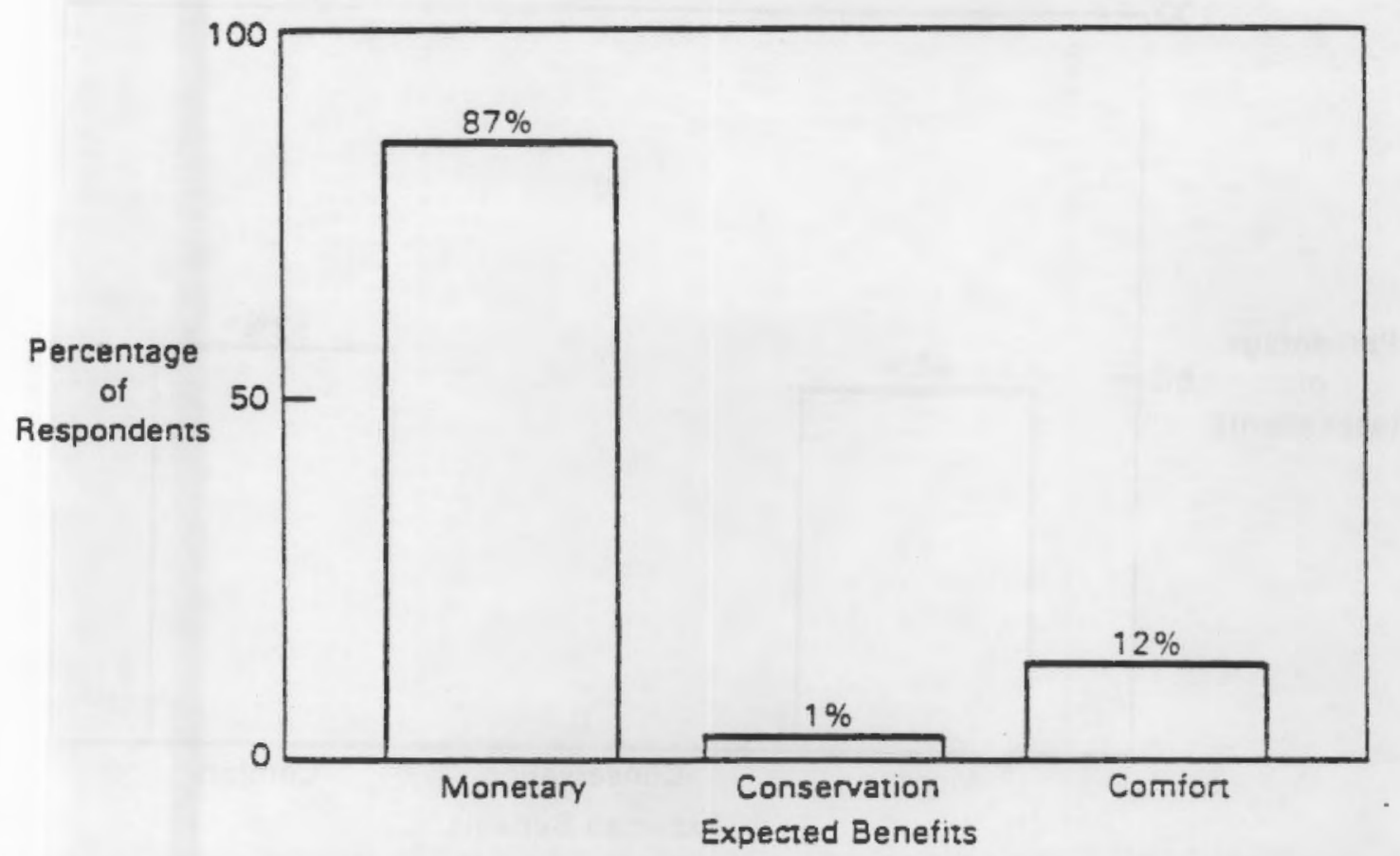

FIGURE 5.16.A. Benefits Expected by Homeowners who Are Somewhat or Very Likely to Install an Automatic Setback Thermostat, All Heating Fuels $(n=127)$

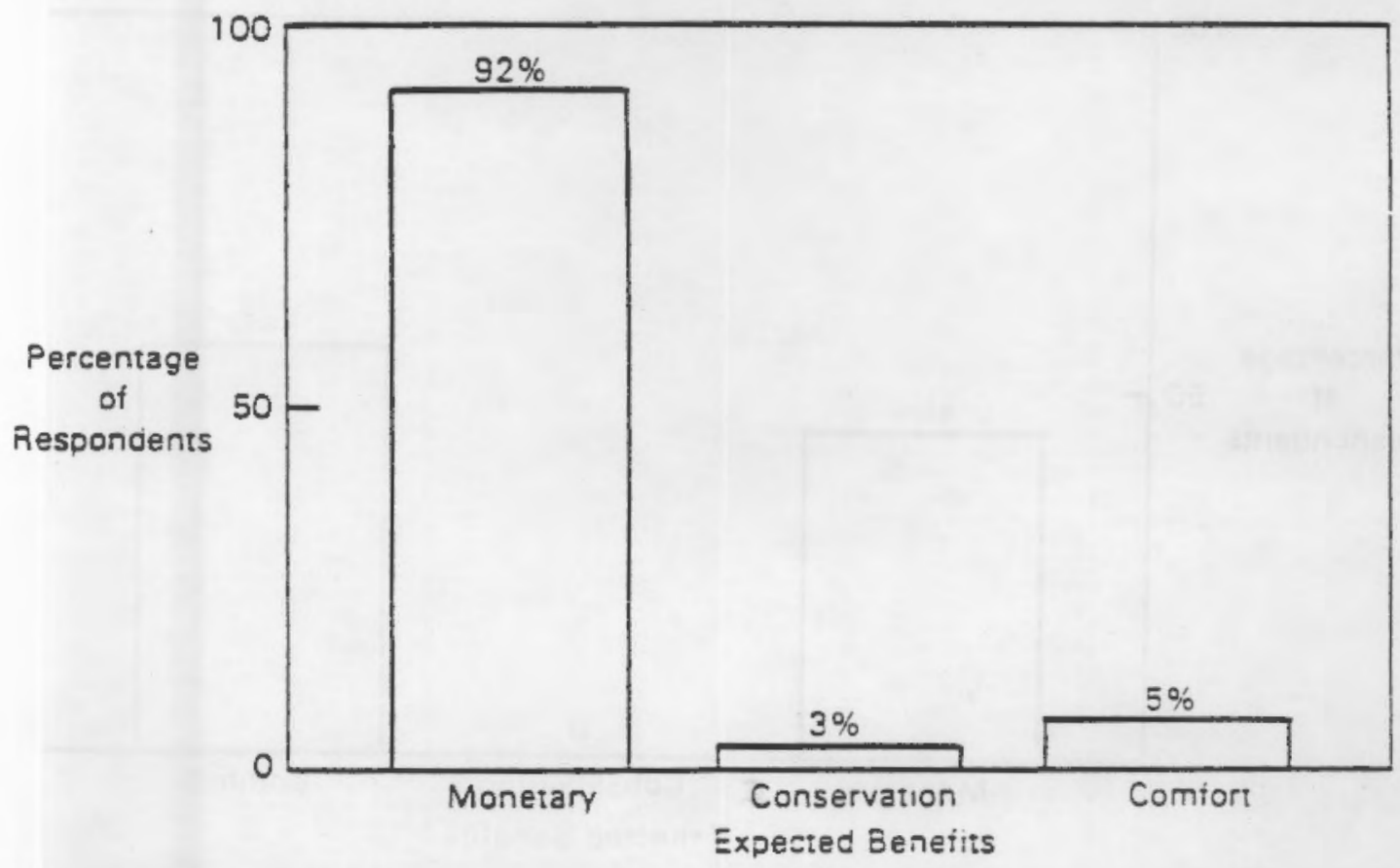

FIGURE 5.16.B. Benefits Expected by Homeowners who Are Somewhat or Very Likely to Install an Automatic Setback Thermostat, Heating Fuel Electric $(n=62)$ 


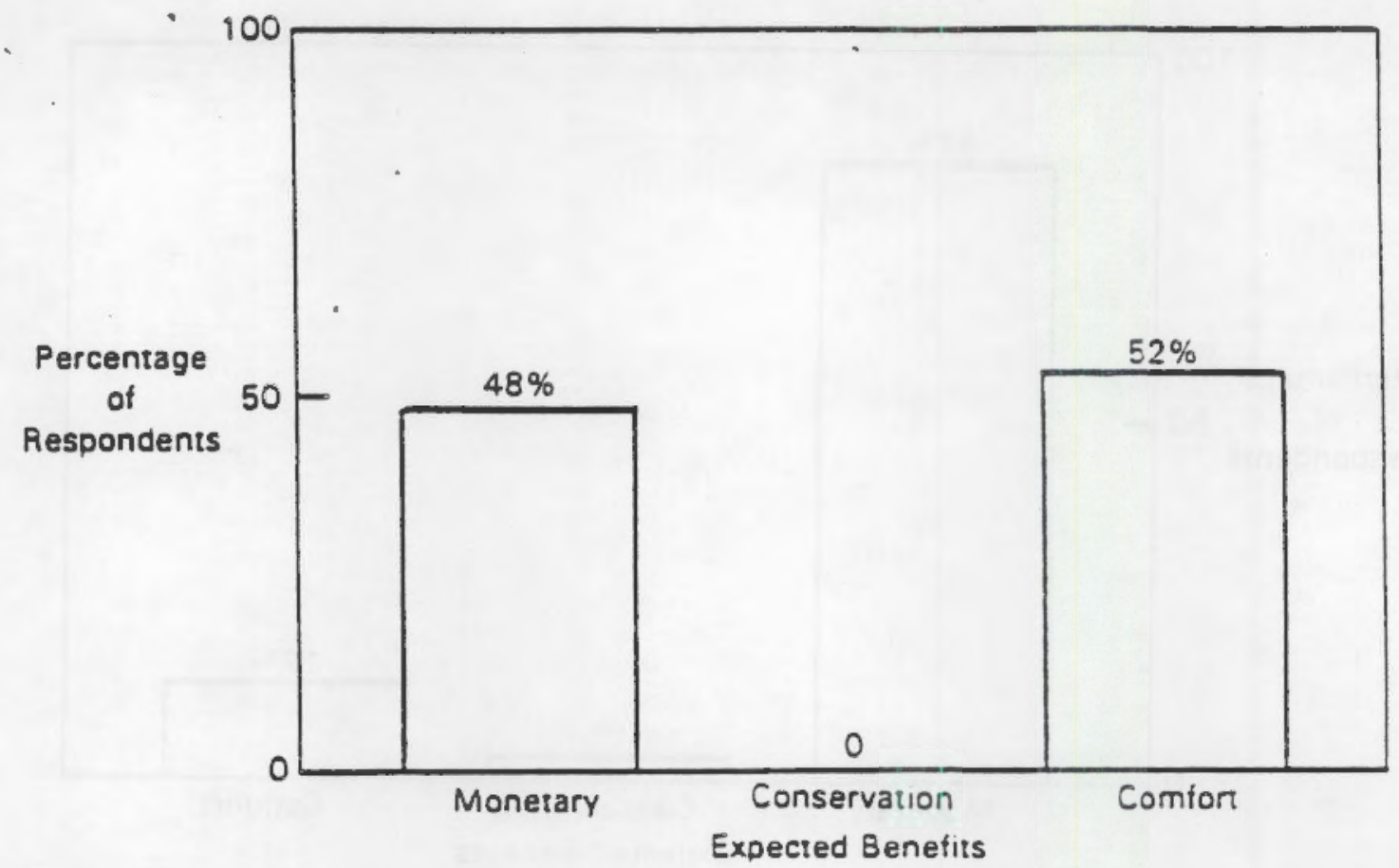

FIGURE 5.17.A. Benefits Expected by Homeowners Who Are Somewhat or Very Likely to Insulate Basement Floor/Crawl Space, All Heating Fuels $(n=175)$

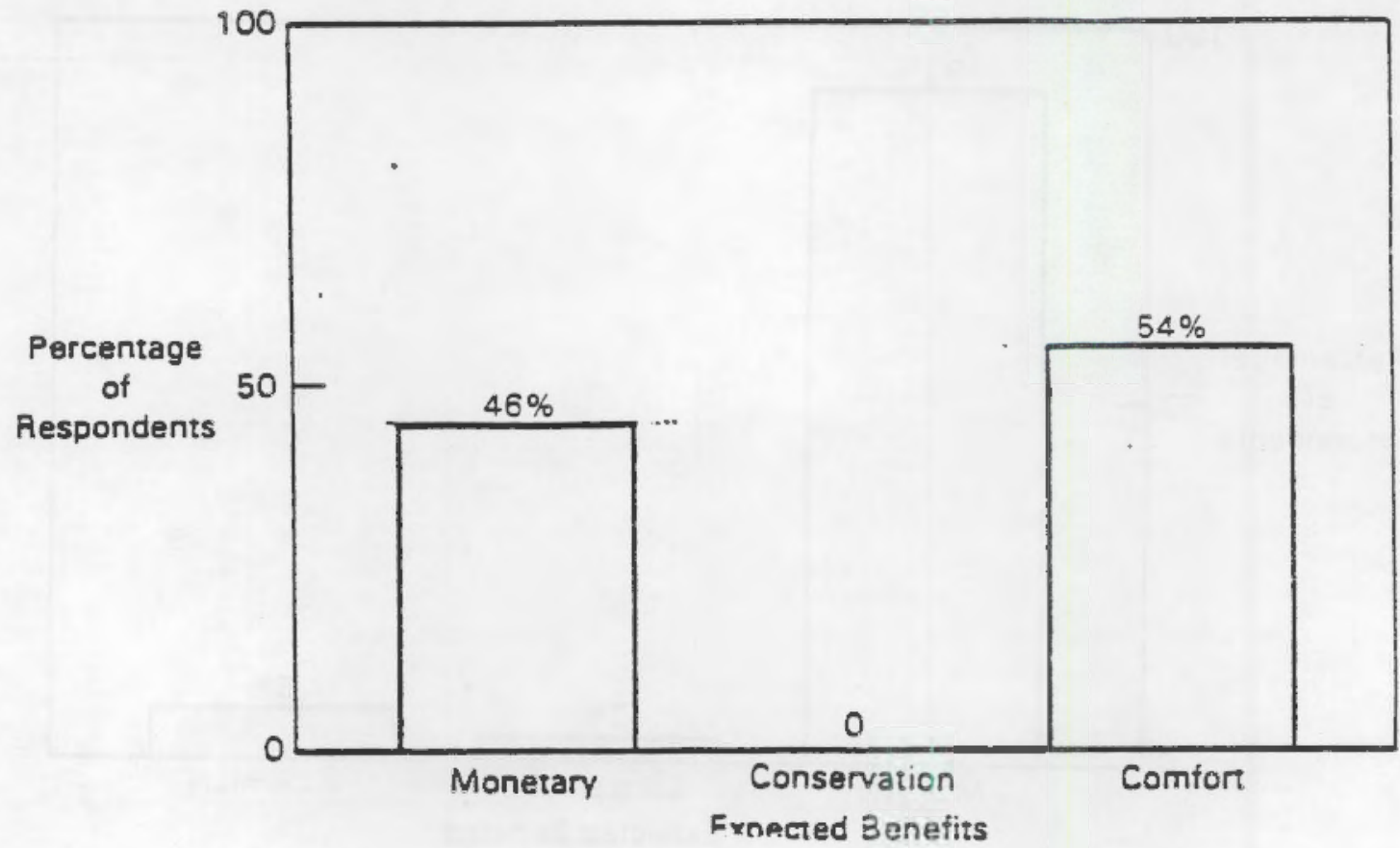

FIGURE 5.17.B. Benefits Expected by Homeowners Who Are Somewhat or Very Likely to Insulate Basement Floor/Crawl Space, Heating Fuel Electric $(n=175)$ 


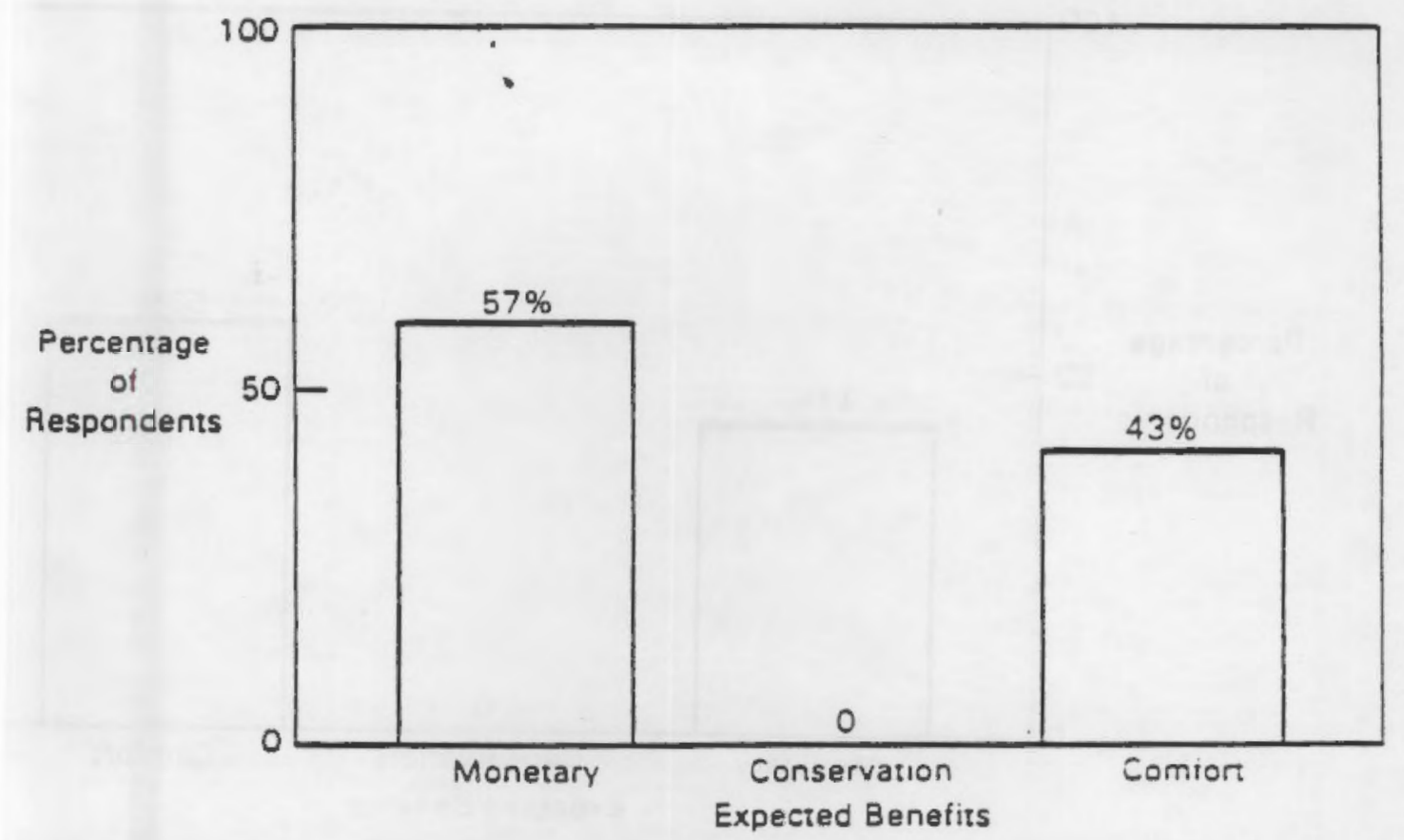

FIGURE 5.18.A. Benefits Expected by Homeowners Who Are Somewhat or Very Likely to Insulate Ouside Walls, All Heating Fuels ( $n=101)$

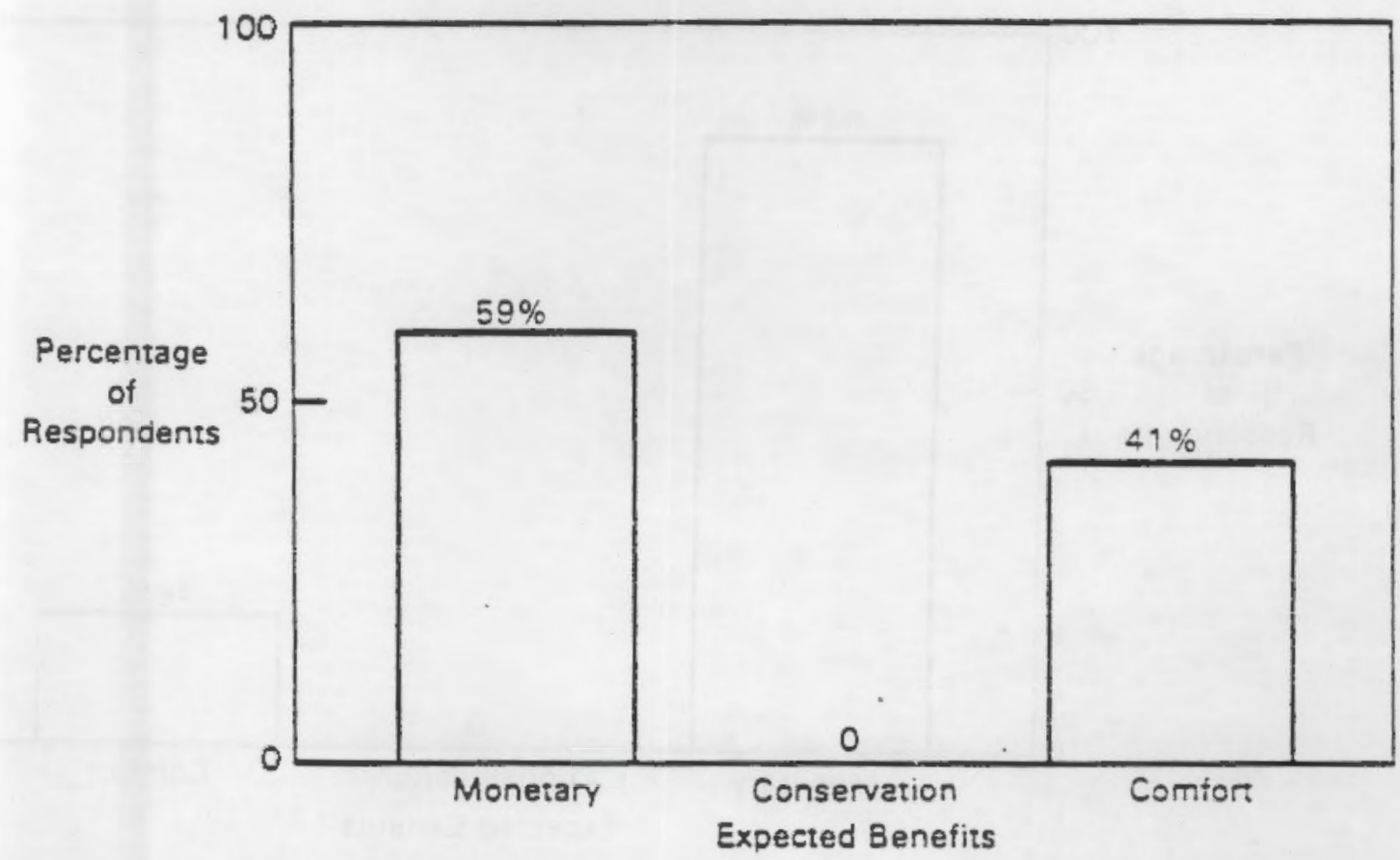

FIGURE 5.18.B. Benefits Expected by Homeowners Who Are Somewhat or Very Likely to Insulate Outside Walls, Heating Fuel Electric $(n=49)$ 


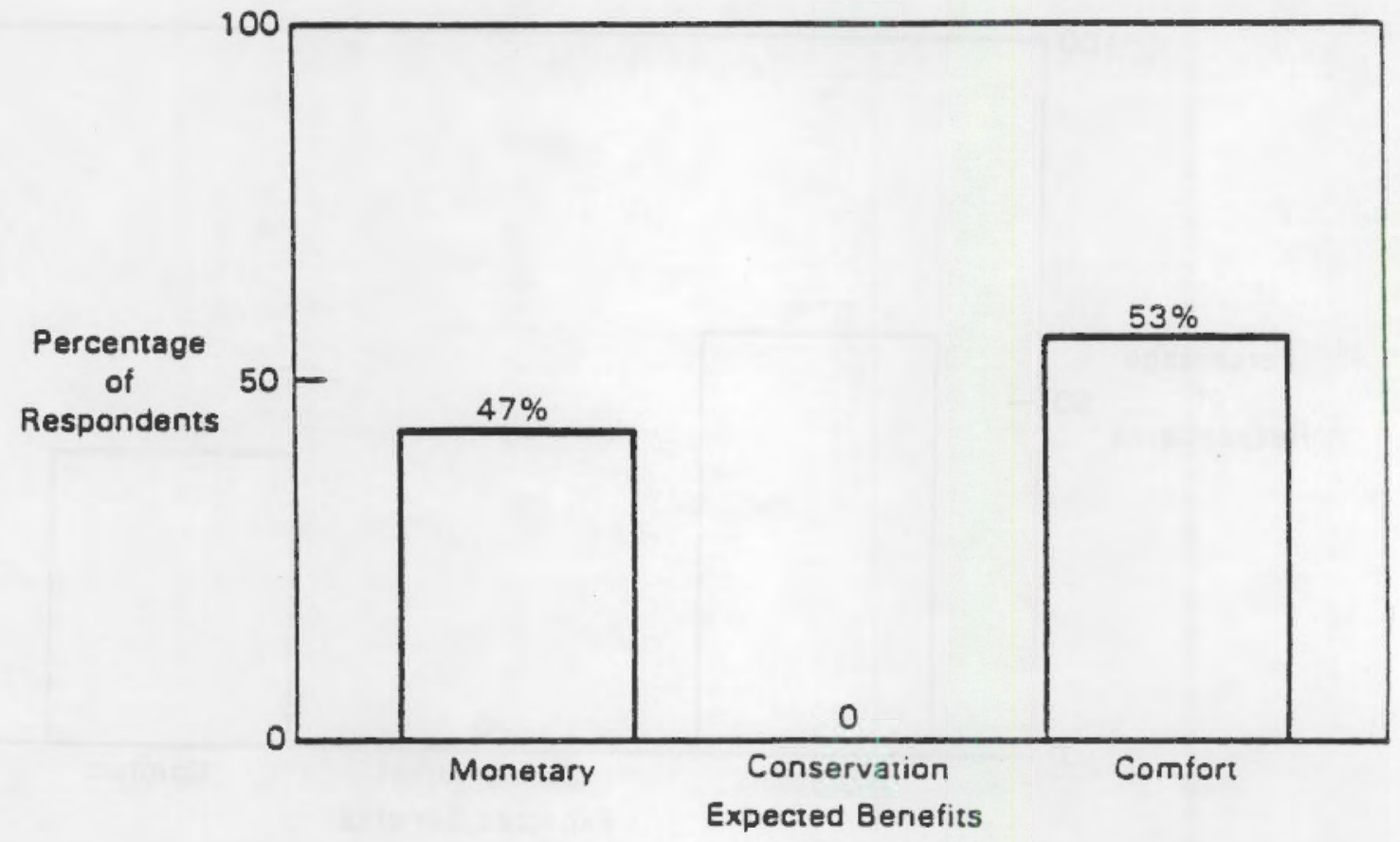

FIGURE 5.19.A. Benefits Expected by Homeowners Who Are Somewhat or Very Likely to Insulate Roofs or Attics, All Heating Fuels $(n=58)$

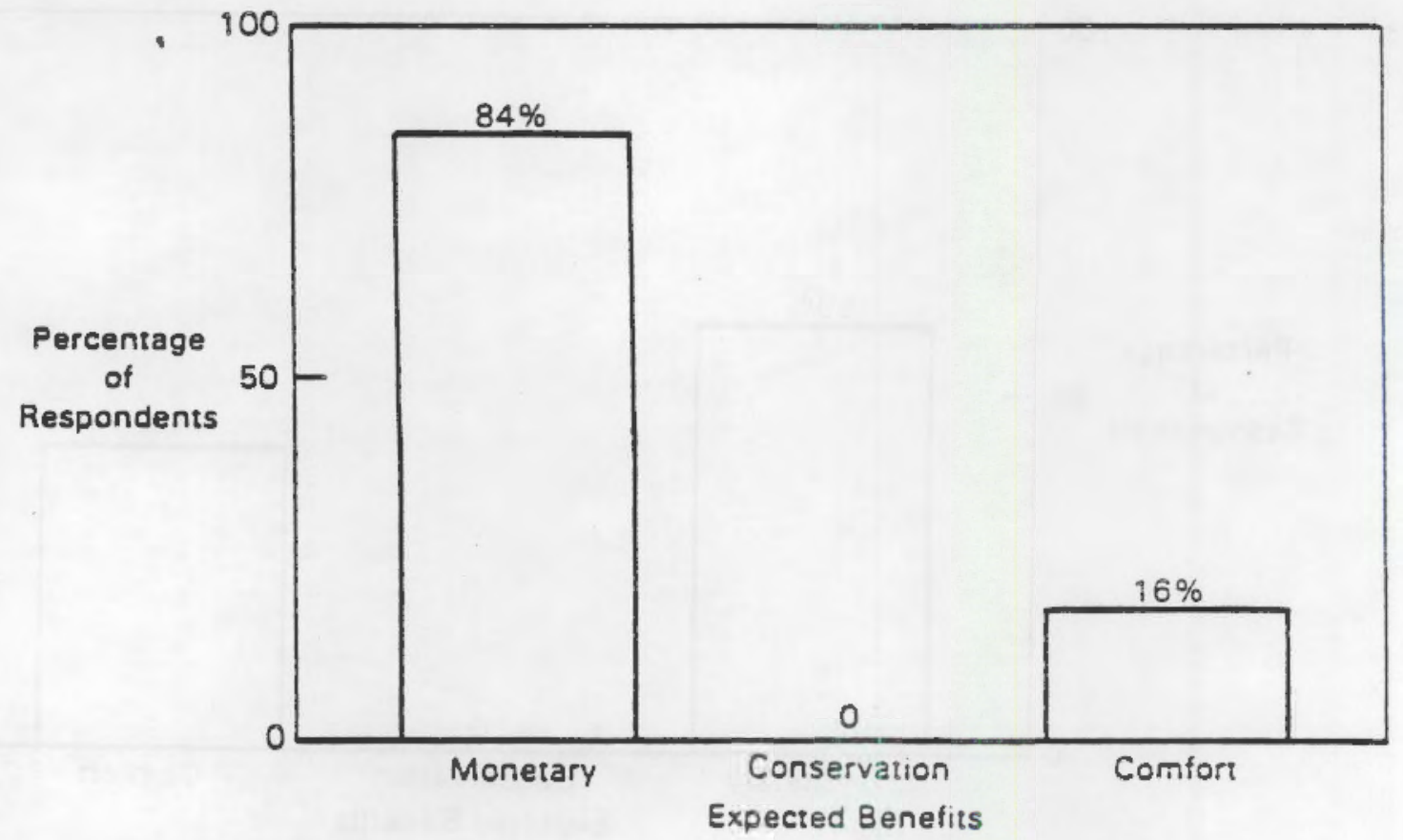

FIGURE 5.19.B. Benefits Expected by Homeowners Who Are Somewhat or Very Likely to Insulate Roofs or Attics, Heating Fuel Electric $(n=20)$ 


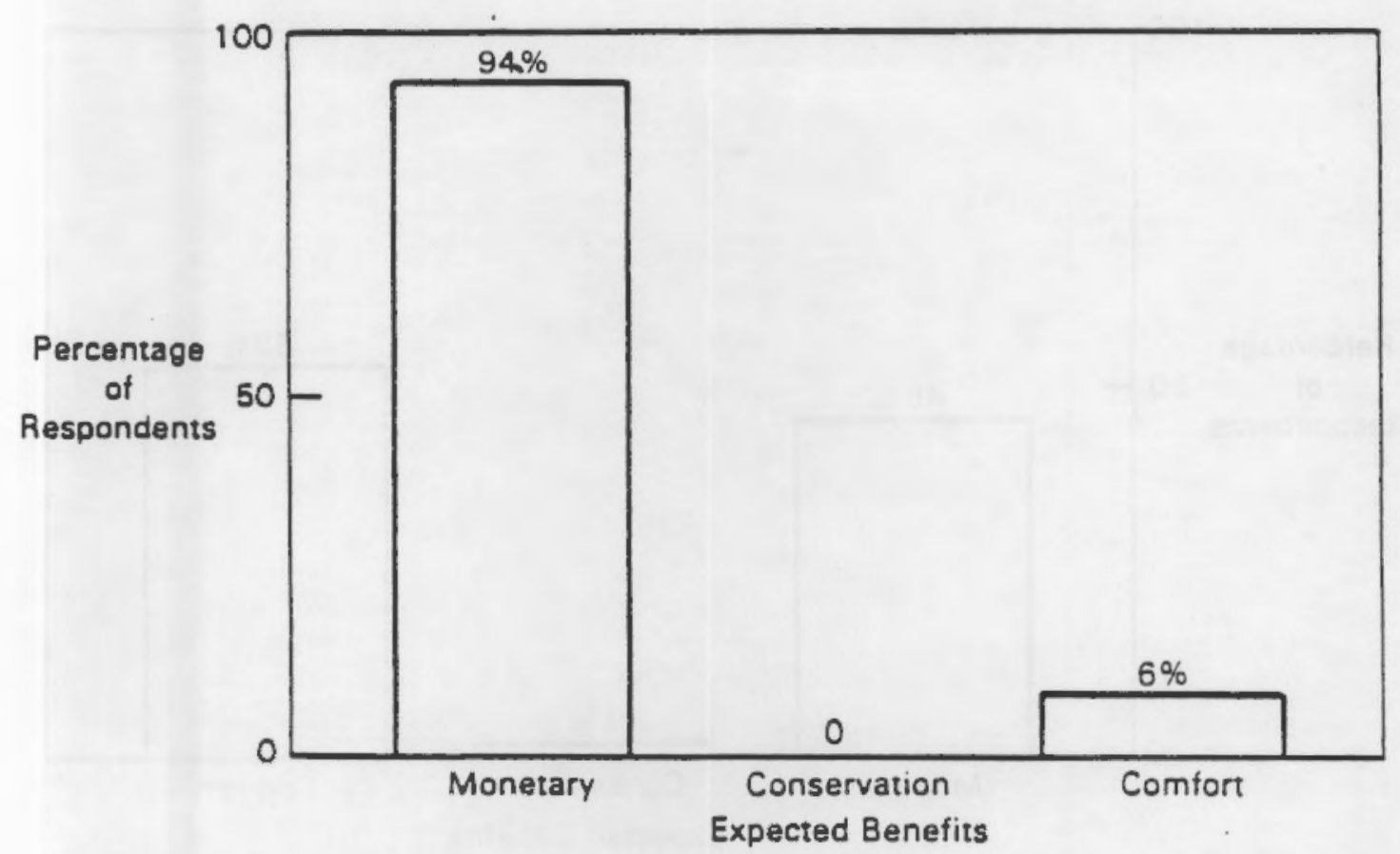

FIGURE 5.20.A. Benefits Expected by Homeowners Who Are Somewhat or Very Likely to Install Solar Panels, All Heating Fuels $(n=180)$

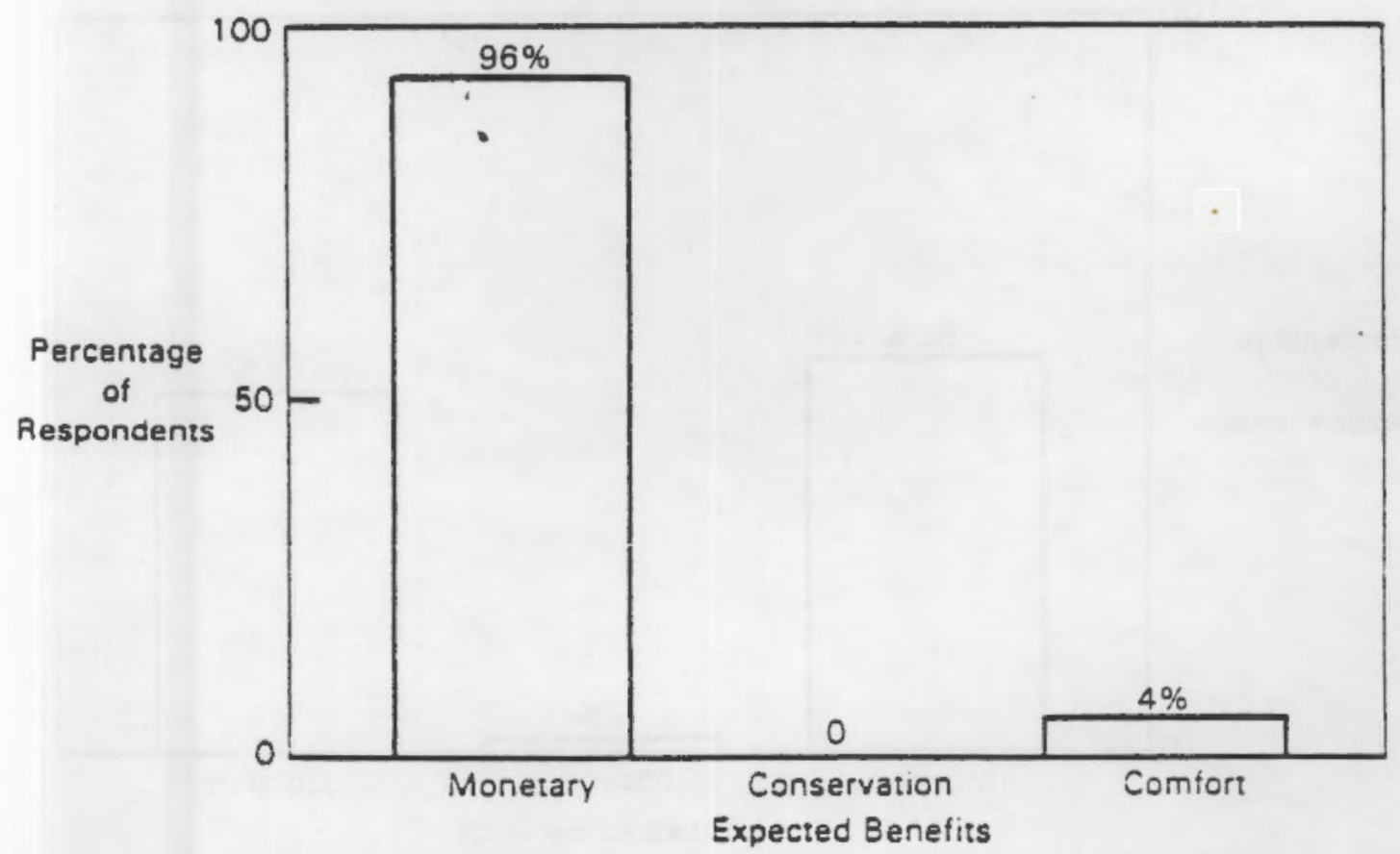

FIGURE 5.20.B. Benefits Expected by Homeowners who Are Somewhat or Very Likely to Install Solar Panels, Heating Fuel Electric $(n=124)$ 


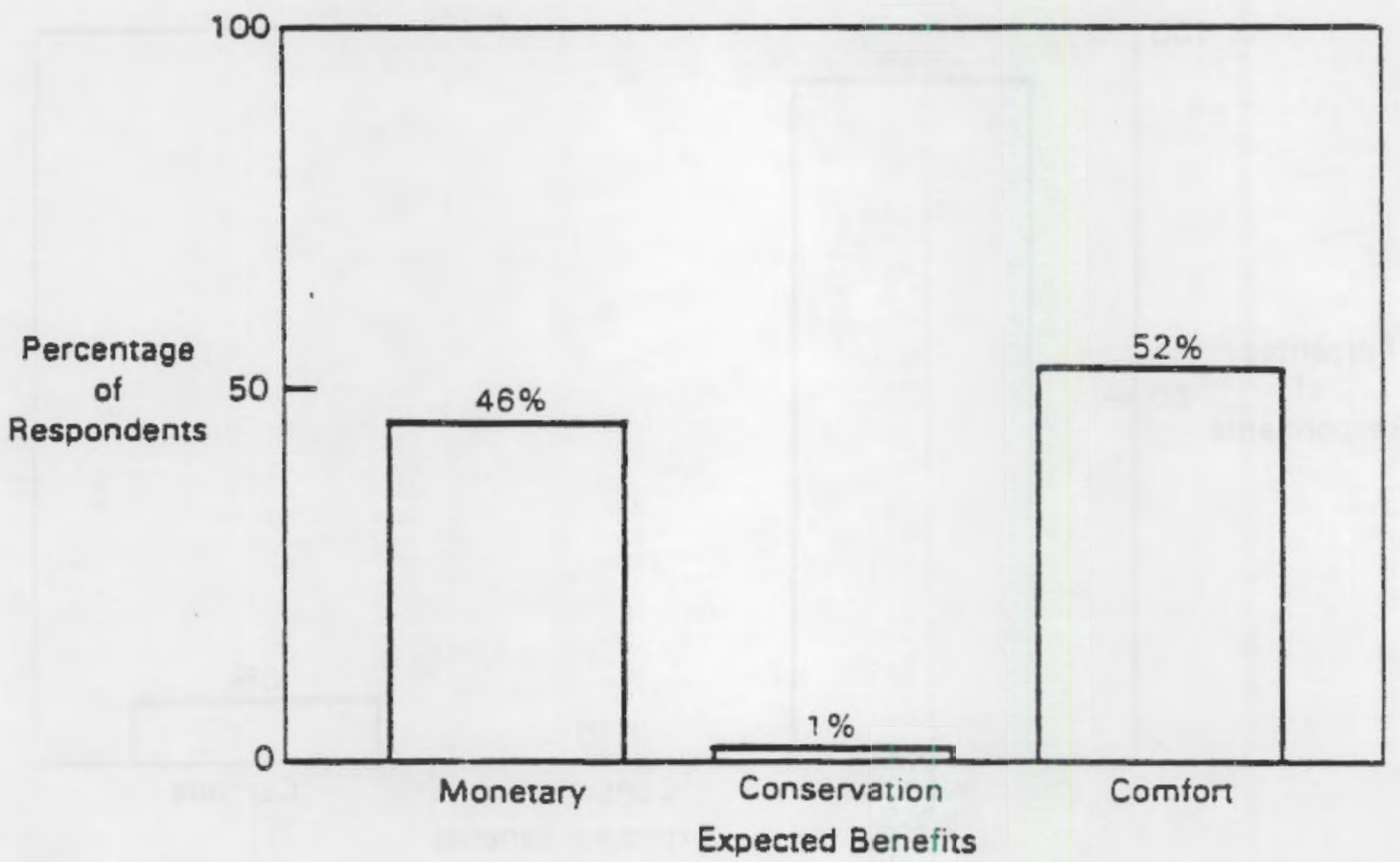

FIGURE 5.21.A. Benefits Expected by Homeowners Who Are Somewhat or Very Likely to Install Storm Doors, All Heating Fuels $(n=297)$

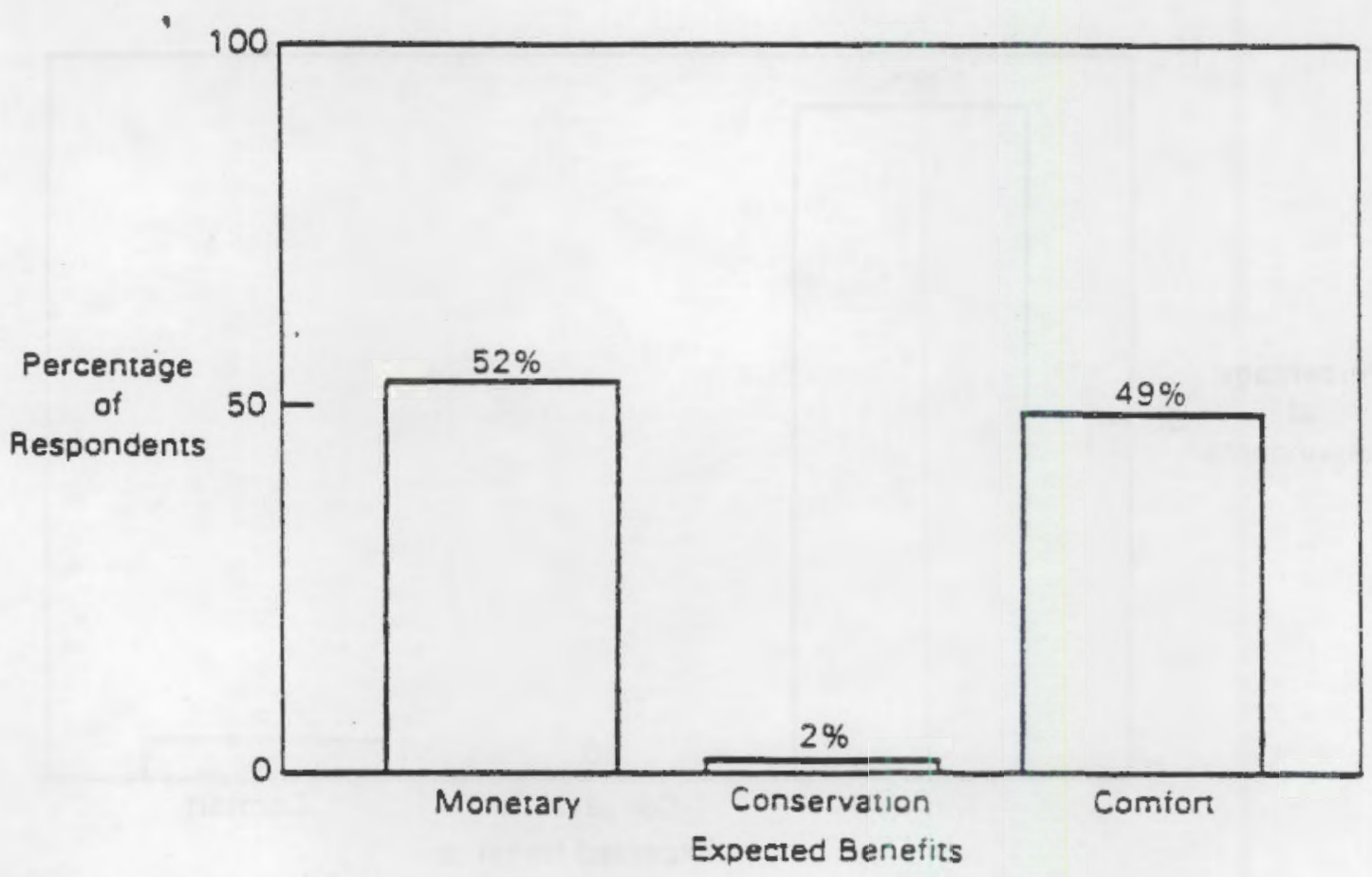

FIGURE 5.21.B. Benefits Expected by Homeowners who Are Somewhat or Very Likely to Install Storm Doors, Heating Fuel Electric $(n=159)$ 


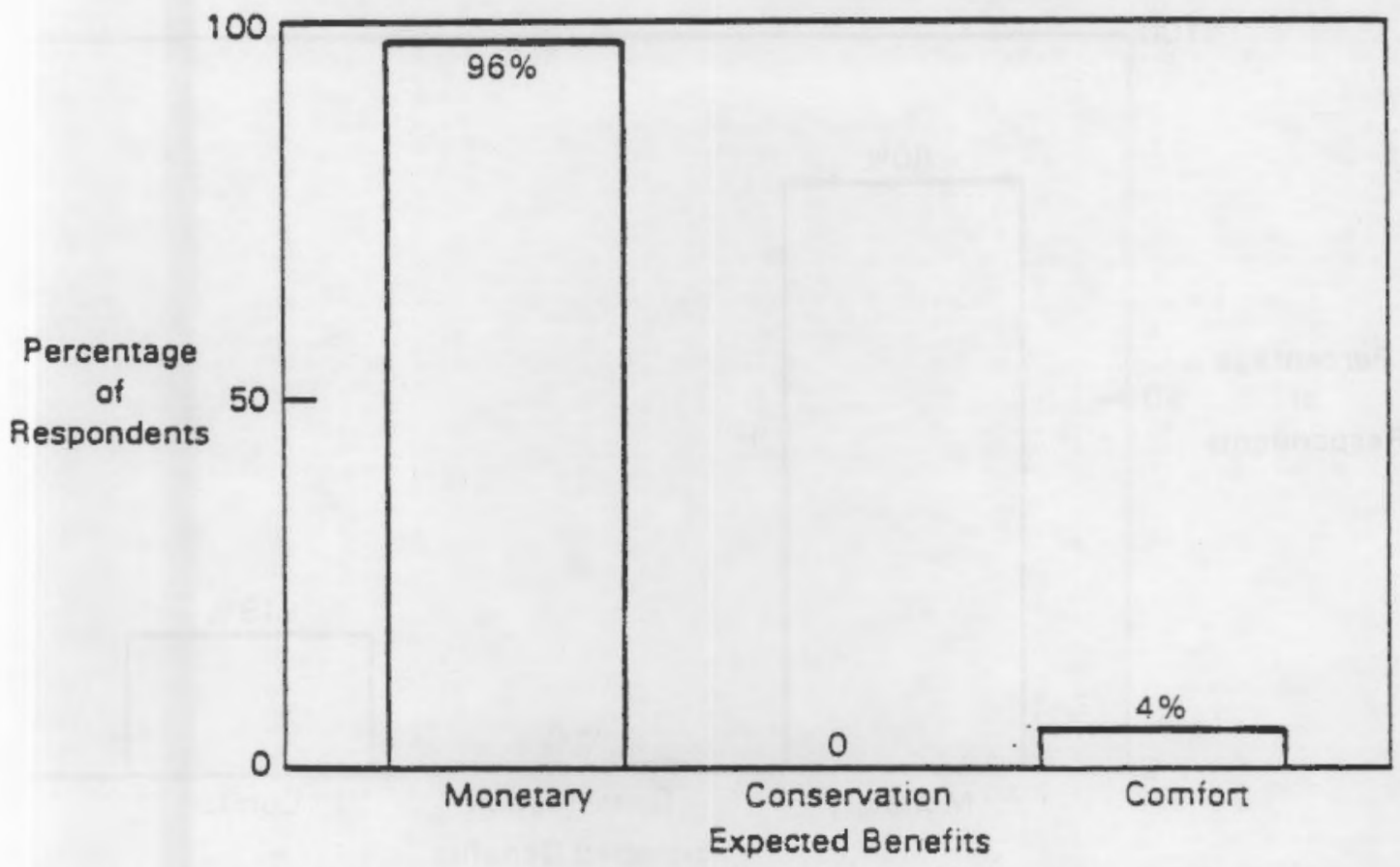

FIGURE 5.22.A. Benefits Expected by Homeowners Who Are Somewhat or Very Likely to Install Heat Pump Water Heaters, All Heating Fuels $(n=144)$

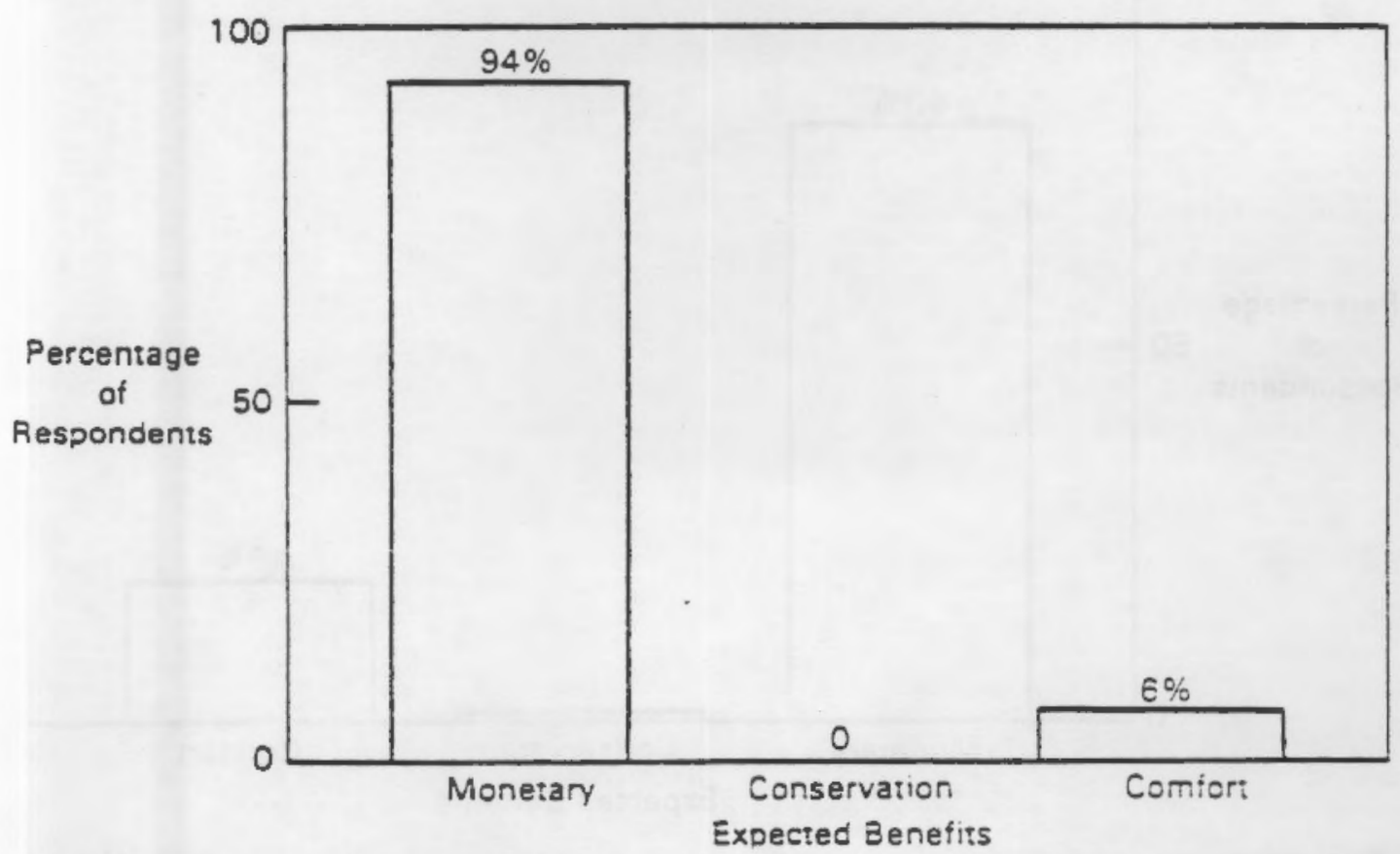

FIGURE 5.22.B. Benefits Expected by Homeowners who Are Somewhat or Very Likely to Install Heat Pump Water Heaters, Heating Fuel Electric $(n=78)$ 


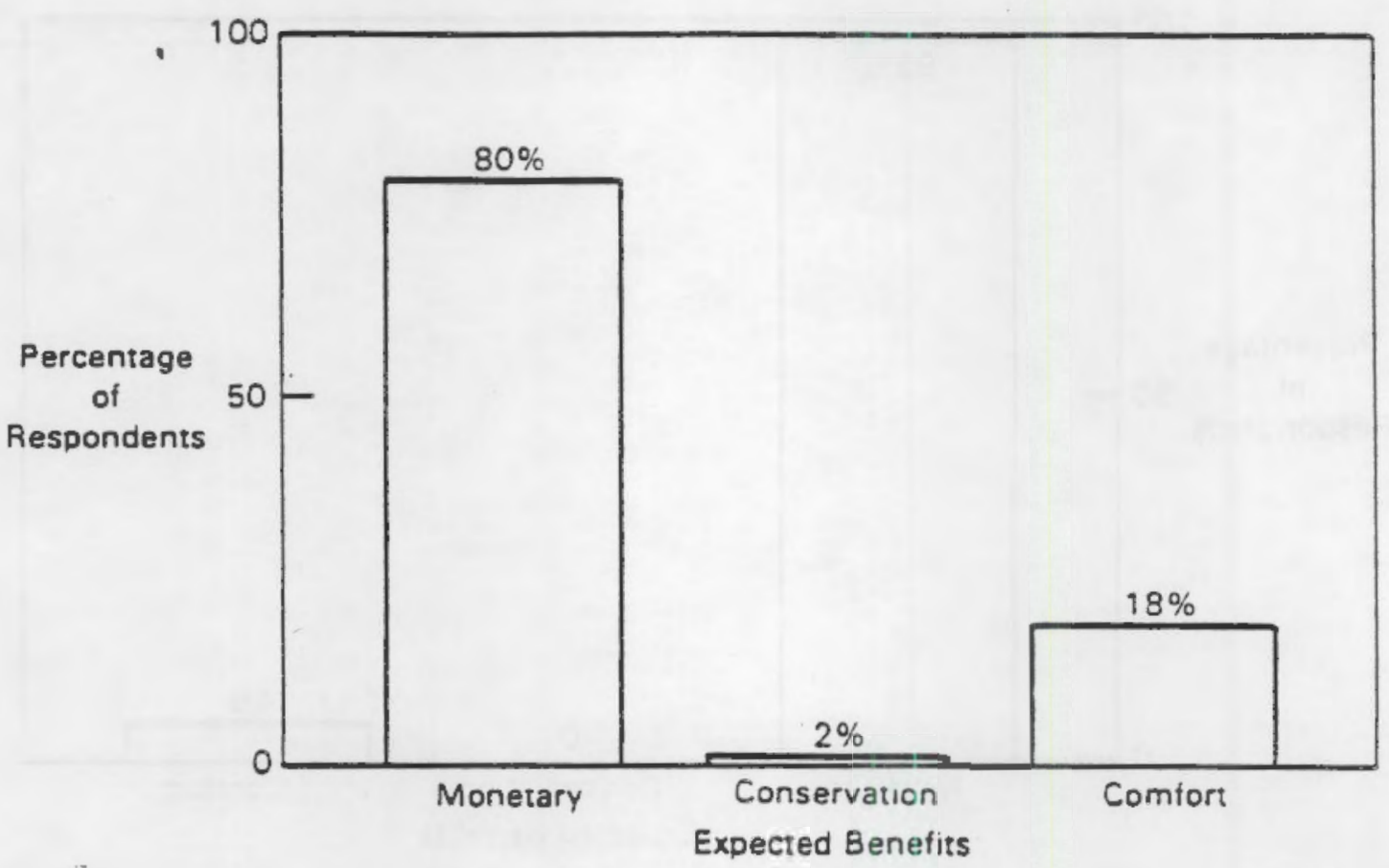

FIGURE 5.23.A. Benefits Expected by Homeowners Who Are Somewhat or Very Likely to Install Wood Stoves, All Heating Fuels ( $n=193)$

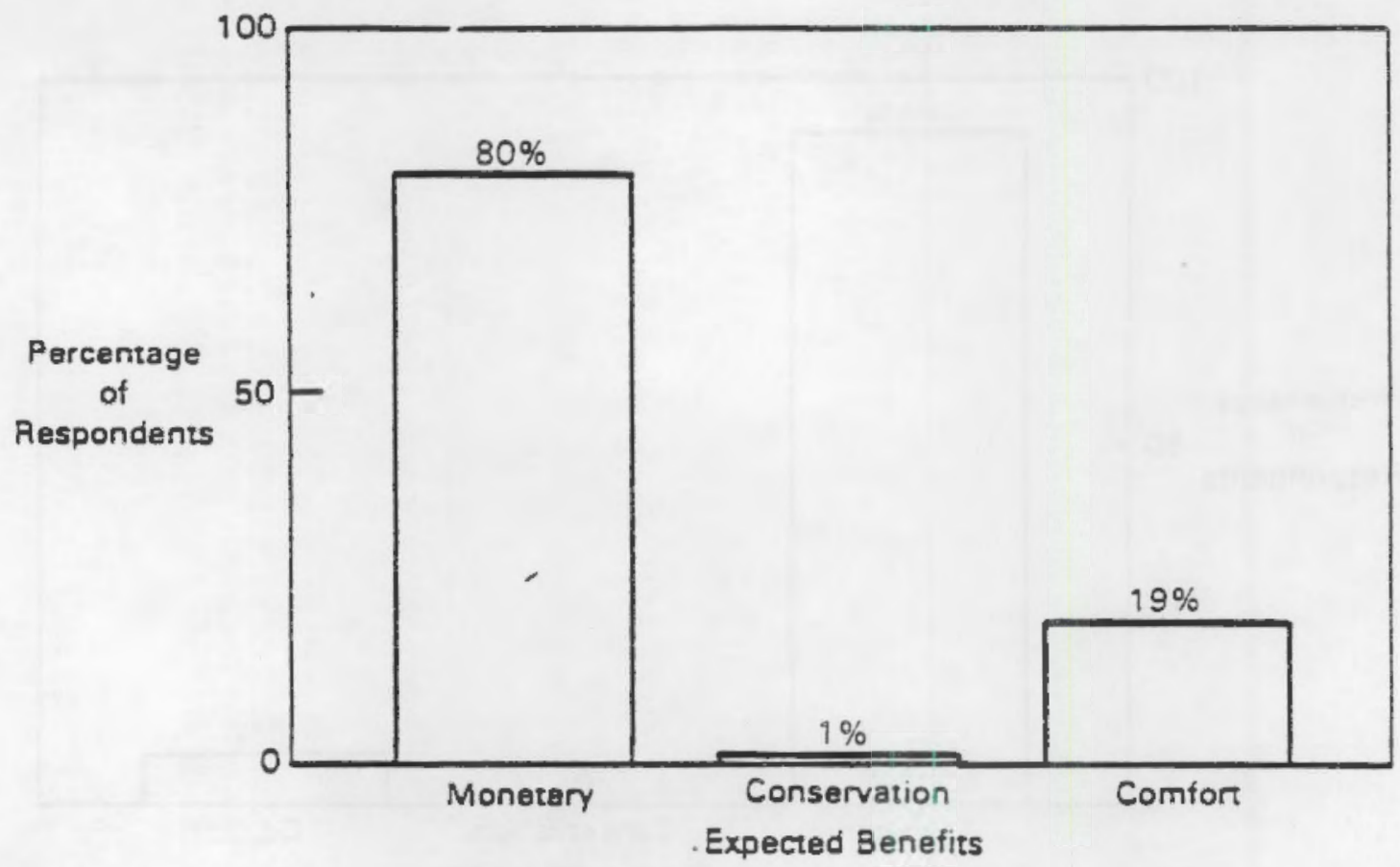

FIGURE 5.23.B. Benefits Expected by Homeowners Who Are Somewhat or Very Likely to Install Wood Stoves, Heating Fuel Electric $(n=111)$ 


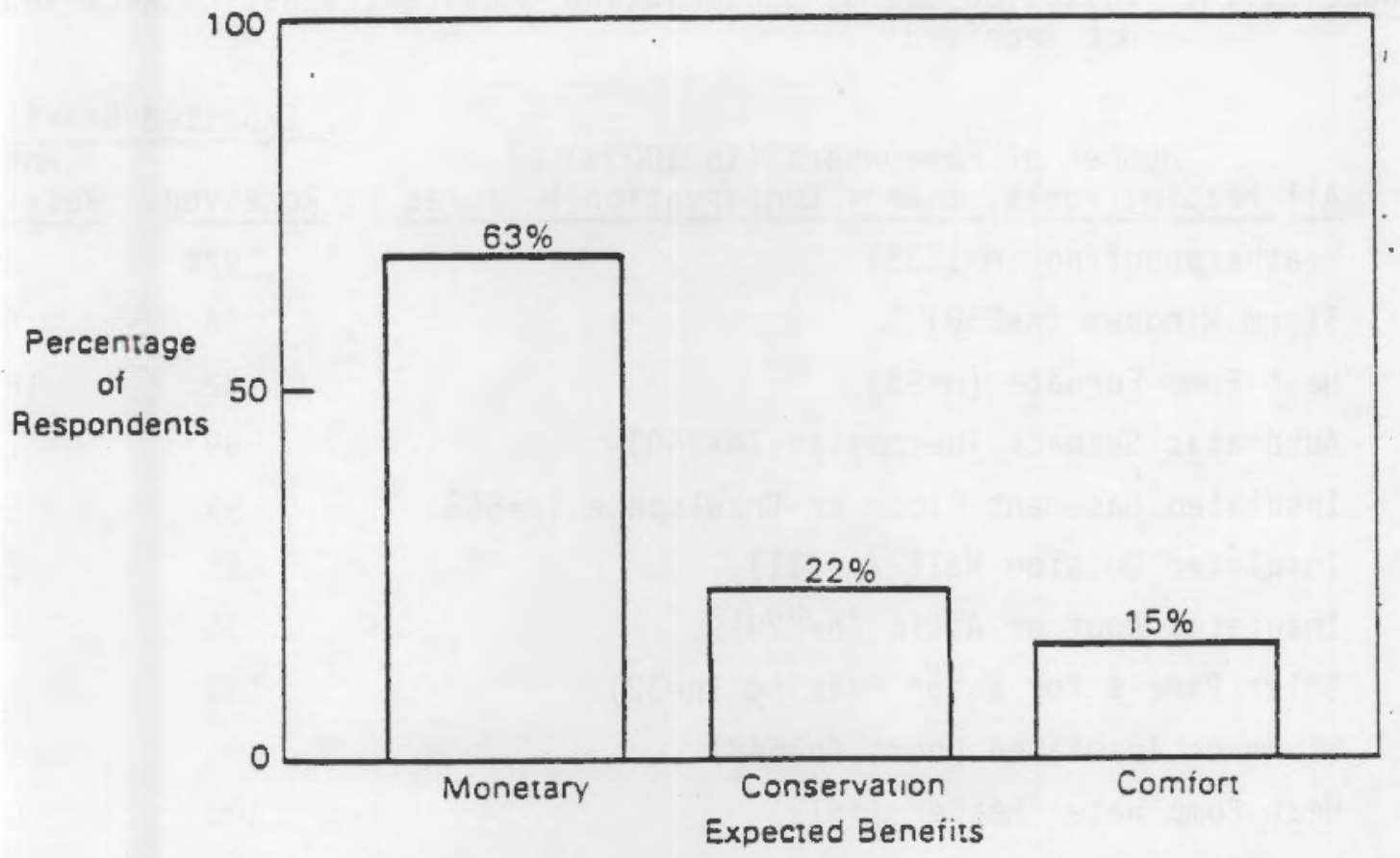

FIGURE 5.24.A. Benefits Expected by Homeowners Who Are Somewhat or Very Likely to Install Fireplace Inserts, All Heating Fuels ( $n=186)$

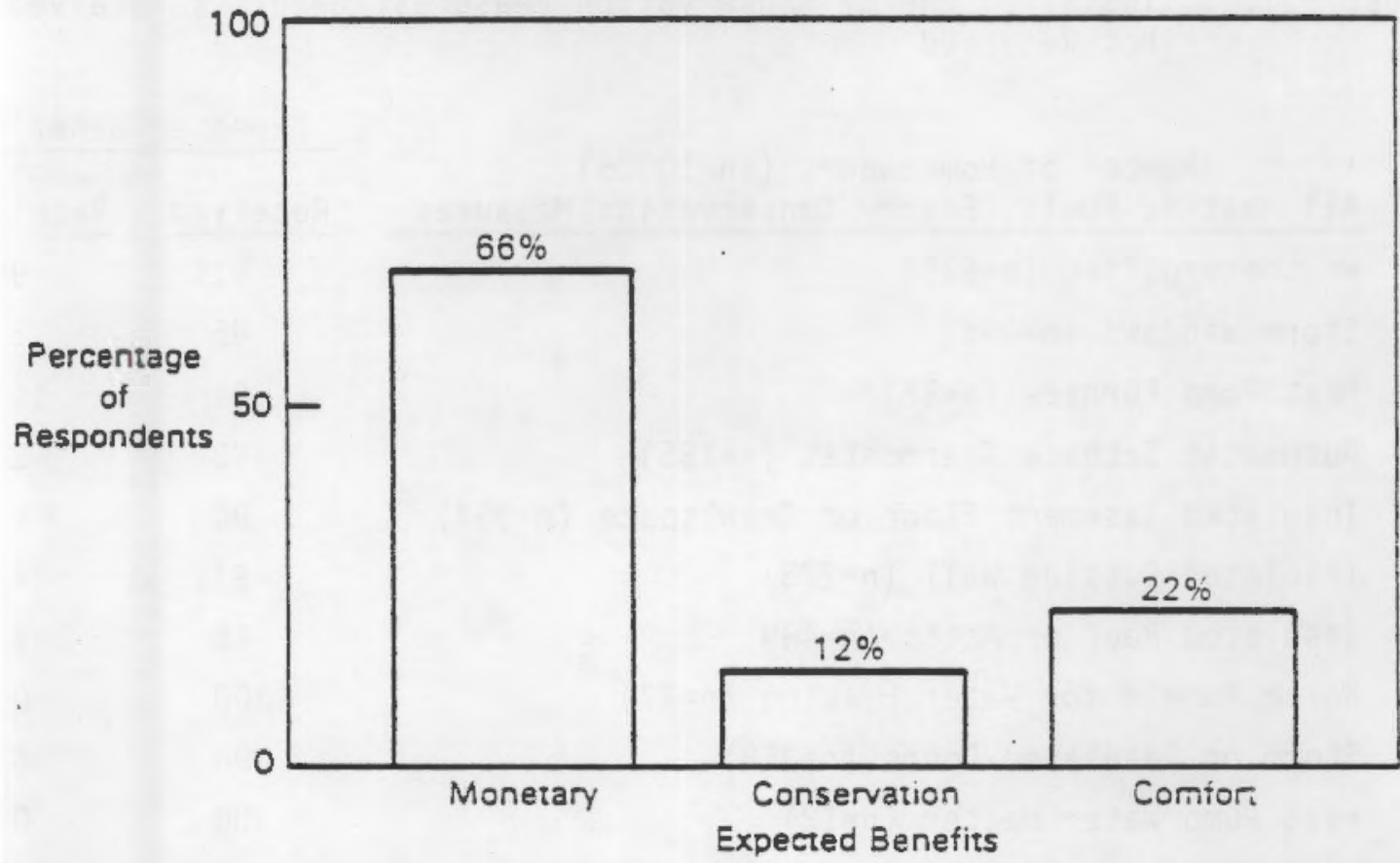

FIGURE 5.24.B. Benefits Expected by Homeowners Who Are Somewhat or Very Likely to Install Fireplace Inserts, Heating Fuel Electric $(n=95)$ 
TABLE 5.1.A. Installed Energy Conservation Measures, Benefits Received Versus Not Received

Number of Homeowners (in 1000s)

All Heating Fuels, Energy Conservation Measures

Weatherproofing ( $n=1135$ )

Storm Windows $(n=858)$

Heat Pump Furnace $(n=93)$

Automatic Setback Thermostat $(n=360)$

Insulated Basement Floor or Crawispace $(n=568)$

Insulated Outside Wall ( $n=511$ )

Insulated Roof or Attic ( $n=828$ )

Solar Panels for Water Heating ( $n=32$ )

Storm or Insulated Doors ( $n=643$ )

Heat Pump Water Heater ( $n=12$ )

Wood Stove or Wood Furnace $(n=630)$

Fireplace Insert $(n=321)$

\begin{tabular}{cc} 
Expected & Benefits \\
\cline { 1 - 1 } Received & $\begin{array}{c}\text { Not } \\
\text { Received }\end{array}$ \\
\cline { 1 - 1 } $92 \%$ & $8 \%$ \\
96 & 4 \\
82 & 18 \\
99 & 1 \\
95 & 5 \\
98 & 2 \\
96 & 4 \\
100 & 0 \\
96 & 4 \\
100 & 0 \\
96 & 4 \\
94 & 6
\end{tabular}

TABLE 5.1.B. Installed Energy Conservation Measures, Benefits Received Versus Not Received

Number of Homeowners (in 1000s)

A11 Heating Fuels, Energy Conservation Measures

Weatherproofing ( $n=685$ )

Storm Windows $(n=496)$

Heat Pump Furnace $(n=86)$

Automatic Setback Thermostat ( $n=185$ )

Insulated Basement Floor or Crawlspace $(n=384)$

Insulated Outside Hall ( $n=273$ )

Expected Benefits

\begin{tabular}{cc}
\hline Received & $\begin{array}{c}\text { Not } \\
\text { Received }\end{array}$ \\
\cline { 1 - 1 } $91 \%$ & $9 \%$ \\
95 & 5
\end{tabular}

Insulated Roof or Attic ( $n=489)$

81

19

Solar Panels for Water Heating $(n=27)$

98

2

94

97

95

100

Storm or Insulated Doors ( $n=358)$

96

Heat Pump Water Heater $(n=12)$

100

Wood Stove or Hood Furnace $(n=337)$

96

91

6

Fireplace Insert $(n=176)$

9 
TABLE 5.2.A. Benefits Expected by Homeowners Installing Weatherproofing

\begin{tabular}{|c|c|c|}
\hline \multirow[b]{2}{*}{$\begin{array}{l}\text { Expected } \\
\text { Benefits }\end{array}$} & \multicolumn{2}{|c|}{$\begin{array}{r}\text { Number of Homeowners }(\text { in 1000s) } \\
\text { AlI Heating Fuels }(n=1048)\end{array}$} \\
\hline & $\begin{array}{c}\text { Received } \\
\text { Expected } \\
\text { Benefits }(n=966)\end{array}$ & $\begin{array}{c}\text { Did Not Receive } \\
\text { Expected } \\
\text { Benefits }(n=81) \\
\end{array}$ \\
\hline Monetary & $45 \%$ & $80 \%$ \\
\hline Conservation & 14 & 2 \\
\hline Comfort & 40 & 18 \\
\hline
\end{tabular}

TABLE 5.2.B. Benefits Expected by Homeowners Installing Weatherproofing

\begin{tabular}{|c|c|c|}
\hline \multirow[b]{2}{*}{$\begin{array}{l}\text { Expected } \\
\text { Benefits }\end{array}$} & \multicolumn{2}{|c|}{$\begin{array}{l}\text { Number of Homeowners (in 1000s) } \\
\text { All Heating Fuels }(n=620)\end{array}$} \\
\hline & $\begin{array}{c}\text { Received } \\
\text { Expected } \\
\text { 8enefits }(n=569)\end{array}$ & $\begin{array}{c}\text { Did Not Receive } \\
\text { Expected } \\
\text { Benefits }(n=51)\end{array}$ \\
\hline Monetary & $50 \%$ & $85 \%$ \\
\hline Conservation & 15 & 0 \\
\hline Comfort & 36 & 15 \\
\hline
\end{tabular}

TABLE 5.3.A. Benefits Expected by Homeowners installing Storm Windows

\begin{tabular}{|c|c|c|}
\hline \multirow[b]{2}{*}{$\begin{array}{l}\text { Expected } \\
\text { Benefits }\end{array}$} & \multicolumn{2}{|c|}{$\begin{array}{r}\text { Number of Homeowners (in 1000s) } \\
\text { All Heating Fuels }(n=807)\end{array}$} \\
\hline & $\begin{array}{c}\text { Received } \\
\text { Expected } \\
\text { Benefits }(n=778)\end{array}$ & $\begin{array}{c}\text { Did Not Receive } \\
\text { Expected } \\
\text { Benefits }(n=29)\end{array}$ \\
\hline Monetary & $41 \%$ & $56 \%$ \\
\hline Conservation & 13 & 0 \\
\hline Comfort & 46 & 44 \\
\hline
\end{tabular}

TABLE 5.3.B. Benefits Expected by Homeowners Installing Storm Windows

\begin{tabular}{|c|c|c|}
\hline $\begin{array}{l}\text { Expected } \\
\text { Benefits }\end{array}$ & $\begin{array}{l}\begin{array}{r}\text { Number of Homeo } \\
\text { All Heating }\end{array} \\
\text { Received } \\
\text { Expected } \\
\text { Benefits }(n=435)\end{array}$ & $\begin{array}{c}\text { Whers (in 1000s) } \\
\text { Fuels }(n=461) \\
\text { Did Not Receive } \\
\text { Expected } \\
\text { Benefits }(n=26)\end{array}$ \\
\hline Monetary & $42 \%$ & $51 \%$ \\
\hline Conservation & 12 & 0 \\
\hline Comfort & 46 & 49 \\
\hline
\end{tabular}


TABLE 5.4.A. Benefits Expected by Homeowners Installing Heat Pump Furnace

\begin{tabular}{lcc} 
& $\begin{array}{c}\text { Number of Homeowners }(i n 1000 s) \\
\text { All Heating Fuels }(n=B 7)\end{array}$ \\
\cline { 2 - 3 } $\begin{array}{c}\text { Expected } \\
\text { Benefits } \\
\text { Meceived } \\
\text { Expected } \\
\text { Monetary }\end{array}$ & $\frac{\text { Benefits }(n=74)}{\text { Expect Receive }}$ & Benefits $(n=13)$ \\
Conservation & $73 \%$ & $100 \%$ \\
Comfort & 7 & 0
\end{tabular}

TABLE 5.4.B. Benefits Expected by Homeowners Installing Heat Pump Furnace

\begin{tabular}{lcc} 
& $\begin{array}{c}\text { Number of Homeowners (in 1000s) } \\
\text { All Heating Fuels }(n=83)\end{array}$ \\
\cline { 2 - 3 } $\begin{array}{c}\text { Expected } \\
\text { Benefits }\end{array}$ & $\begin{array}{c}\text { Expected } \\
\text { Benefits }(n=70)\end{array}$ & $\begin{array}{c}\text { Did Not Receive } \\
\text { Expected }\end{array}$ \\
$\begin{array}{l}\text { Monetary } \\
\text { Conservation }\end{array}$ & $74 \%$ & $100 \%$ \\
Comfort & 7 & 0
\end{tabular}

TABLE 5.5.A. Benefits Expected by Homeowners Installing Automatic or Setback Thermostat

\begin{tabular}{|c|c|c|}
\hline \multirow[b]{2}{*}{$\begin{array}{l}\text { Expected } \\
\text { Benefits }\end{array}$} & \multicolumn{2}{|c|}{$\begin{array}{r}\text { Number of Homeowners (in 1000s) } \\
\text { All Heating Fuels }(n=295)\end{array}$} \\
\hline & $\begin{array}{c}\text { Received } \\
\text { Expected } \\
\text { Benefits }(n=291) \\
\end{array}$ & $\begin{array}{c}\text { Did Not Receive } \\
\text { Expected } \\
\text { Benefits }(n=3)\end{array}$ \\
\hline Monetary & $56 \%$ & $100 \%$ \\
\hline Conservation & 11 & 0 \\
\hline Comfort & 33 & 0 \\
\hline
\end{tabular}


IABLE 5.5.B. Benefits Expected by Homeowners Instailing Automatic or Setback Thermostat

\begin{tabular}{|c|c|c|}
\hline \multirow[b]{2}{*}{$\begin{array}{l}\text { Expected } \\
\text { Benefits }\end{array}$} & \multicolumn{2}{|c|}{$\begin{array}{l}\text { Number of Homeowners (in 1000s) } \\
\text { All Heating Fuels }(n=151)\end{array}$} \\
\hline & $\begin{array}{c}\text { Received } \\
\text { Expected } \\
\text { Benefits } \quad(n=149) \\
\end{array}$ & $\begin{array}{l}\text { Did Not Receive } \\
\text { Expected } \\
\text { Benefits }(n=2)\end{array}$ \\
\hline Monetary & $47 \%$ & $100 \%$ \\
\hline Conservation & 9 & 0 \\
\hline Comfort & 44 & 0 \\
\hline
\end{tabular}

TABLE 5.6.A. Benefits Expected by Homeowners Insulating Basement Floor or Crawlspace

\begin{tabular}{|c|c|c|}
\hline \multirow[b]{2}{*}{$\begin{array}{l}\text { Expected } \\
\text { Benefits } \\
\end{array}$} & \multicolumn{2}{|c|}{$\begin{array}{r}\text { Number of Homeowners (in 1000s) } \\
\text { AlT Heating Fuels }(n=556)\end{array}$} \\
\hline & $\begin{array}{c}\text { Received } \\
\text { Expected } \\
\text { Benefits }(n=526) \\
\end{array}$ & $\begin{array}{c}\text { Did Not Receive } \\
\text { Expected } \\
\text { Benefits }(n=30)\end{array}$ \\
\hline Monetary & $36 \%$ & $6 \%$ \\
\hline Conservation & 12 & 26 \\
\hline Comfort & 53 & 69 \\
\hline
\end{tabular}

TARLE 5.6.8. Benefits Expected by Homeowners Insulating Basement Floor or Crawlspace

\begin{tabular}{lcc} 
& $\begin{array}{c}\text { Number of Homeowners }(\text { in 1000s }) \\
\text { All Heating Fuels }(n=376)\end{array}$ \\
\cline { 2 - 3 } $\begin{array}{c}\text { Expected } \\
\text { Benefits } \\
\text { Monetary }\end{array}$ & $\frac{\begin{array}{c}\text { Expected } \\
\text { Benefits }(n=352)\end{array}}{\text { Expected }} \begin{array}{c}\text { Expecive } \\
\text { Benefits }(n=24)\end{array}$ \\
Conservation & $33 \%$ & $7 \%$ \\
Comfort & 12 & 33
\end{tabular}


TABLE 5.7.A. Benefits Expected by Homeowners Insulating Outside Wall

\begin{tabular}{lcc} 
& $\begin{array}{c}\text { Number of Homeowners }(i n 1000 s) \\
\text { All Heating Fuels }(n=477)\end{array}$ \\
\cline { 2 - 3 } $\begin{array}{c}\text { Expected } \\
\text { Benefits }\end{array}$ & $\frac{\begin{array}{c}\text { Expected } \\
\text { Benefits }(n=474)\end{array}}{\text { Monetary }}$ & $\frac{\begin{array}{c}\text { Bd Not Receive } \\
\text { Expected }\end{array}}{\text { Benefits }(n=4)}$ \\
Conservation & $37 \%$ & $0 \%$ \\
Comfort & 15 & 54
\end{tabular}

TABLE 5.7.8. Benefits Expected by Homeowners Insulating Outside Wall

\begin{tabular}{|c|c|c|}
\hline \multirow[b]{2}{*}{$\begin{array}{l}\text { Expected } \\
\text { Benefits } \\
\end{array}$} & \multicolumn{2}{|c|}{$\begin{array}{r}\text { Number of Homeowners (in 1000s) } \\
\text { A1! Heating Fuels }(n=252)\end{array}$} \\
\hline & $\begin{array}{c}\text { Received } \\
\text { Expected } \\
\text { Benef } j t 5 \quad(n=250)\end{array}$ & $\begin{array}{c}\text { Did Not Receive } \\
\text { Expected } \\
\text { Benefits }(n=2)\end{array}$ \\
\hline Monetary & $35 \%$ & $0 \%$ \\
\hline Conservation & 13 & 0 \\
\hline Comfort & 53 & 100 \\
\hline
\end{tabular}

TABLE 5.8.A. Benefits Expected by Homeowners Insulating Roof

$\frac{\begin{array}{c}\text { Expected } \\ \text { Benefits }\end{array}}{\text { Monetary }}$

Conservation

Comfort
Number of Homeowners (in 100Ds)

A1) Heating Fuels $(n=783)$

Received Did Not Receive
Expected
Expected

Benefits $(n=756) \quad$ Benefits $(n=27)$

$38 \%$

16

47
$42 \%$

8

51 
TABLE 5.8.8. Benefits Expected by Homeowners Insulating Roof

\begin{tabular}{|c|c|c|}
\hline \multirow[b]{2}{*}{$\begin{array}{l}\text { Expected } \\
\text { Benefits }\end{array}$} & \multicolumn{2}{|c|}{$\begin{array}{r}\text { Number of Homeowners (in 1000s) } \\
\text { All Heating Fuels }(n=459)\end{array}$} \\
\hline & $\begin{array}{c}\text { Received } \\
\text { Expected } \\
\text { Benefits }(n=443) \\
\end{array}$ & $\begin{array}{c}\text { Did Not Receive } \\
\text { Expected } \\
\text { Benefits }(n=16)\end{array}$ \\
\hline Monetary & $36 \%$ & $36 \%$ \\
\hline Conservation & 15 & 0 \\
\hline Comfort & 49 & 64 \\
\hline
\end{tabular}

TABLE 5.9.A. Benefits Expected by Homeowners Installing Solar Panels

\begin{tabular}{lcc} 
& $\begin{array}{c}\text { Number of Homeowners (in 1000s) } \\
\text { All Heating Fuels }(n=32)\end{array}$ \\
\cline { 2 - 3 } $\begin{array}{c}\text { Expected } \\
\text { Renefived } \\
\text { Expected }\end{array}$ & $\begin{array}{c}\text { Oid Not Receive } \\
\text { Expected } \\
\text { Benefits }(n=32)\end{array}$ & $\frac{\text { Benefits }(n=0)}{0 \%}$ \\
\cline { 2 - 3 } Monetary & $47 \%$ & 0 \\
Conservation & 53 & 0
\end{tabular}

TABLE 5.9.B. Benefits Expected by Homeowners Installing Solar Panels

\begin{tabular}{|c|c|c|}
\hline \multirow[b]{2}{*}{$\begin{array}{l}\text { Expected } \\
\text { Benefits }\end{array}$} & \multicolumn{2}{|c|}{$\begin{array}{l}\text { Number of Homeowners (in 1000s) } \\
\text { A]l Heating Fuels }(n=24)\end{array}$} \\
\hline & $\begin{array}{c}\text { Received } \\
\text { Expected } \\
\text { Benefits }(n=24) \\
\end{array}$ & $\begin{array}{c}\text { Did Not Receive } \\
\text { Expected } \\
\text { Benefjts }(n=0)\end{array}$ \\
\hline Monetary & $48 \%$ & $0 \%$ \\
\hline Conservation & 52 & 0 \\
\hline Comfort & 0 & 0 \\
\hline
\end{tabular}


TABLE 5.10.A. Benefits Expected by Homeowners Installing Storm/Insulated Doors

\begin{tabular}{|c|c|c|}
\hline \multirow[b]{2}{*}{$\begin{array}{l}\text { Expected } \\
\text { Benefits }\end{array}$} & \multicolumn{2}{|c|}{$\begin{array}{l}\text { Number of Homeowners (in 1000s) } \\
\text { Al) Heating Fuels }(n=614)\end{array}$} \\
\hline & $\begin{array}{c}\text { Received } \\
\text { Expected } \\
\text { Benefits }(n=590) \\
\end{array}$ & $\begin{array}{c}\text { Did Not Receive } \\
\text { Expected } \\
\text { Benefits }(n=24)\end{array}$ \\
\hline Monetary & $23 \%$ & $22 \%$ \\
\hline Conservation & 16 & 0 \\
\hline Comfort & 60 & 78 \\
\hline
\end{tabular}

TABLE 5.10.8. Benefits Expected by Homeowners Installing Storm/Insulated Doors

\begin{tabular}{|c|c|c|}
\hline \multirow[b]{2}{*}{$\begin{array}{l}\text { Expected } \\
\text { Benefits }\end{array}$} & \multicolumn{2}{|c|}{$\begin{array}{r}\text { Number of Homeowners (in 1000s) } \\
\text { Al) Heating Fuels }(n=341)\end{array}$} \\
\hline & $\begin{array}{c}\text { Received } \\
\text { Expected } \\
\text { Benefits }(n=325)\end{array}$ & $\begin{array}{c}\text { Did Not Receive } \\
\text { Expected } \\
\text { Benefits }(n=16)\end{array}$ \\
\hline Monetary & $27 \%$ & $23 \%$ \\
\hline Conservation & 18 & 0 \\
\hline Comfort & 55 & 77 \\
\hline
\end{tabular}

TABLE 5.11.A. Benefits Expected by Homeowners Installing Heat Pump Water Heater

$\begin{array}{lcc}\begin{array}{c}\text { Expected } \\ \text { Benefits }\end{array} & \begin{array}{c}\text { All Heating Fuels }(n=12) \\ \text { Received } \\ \text { Expected }\end{array} & \begin{array}{c}\text { Did Not Receive } \\ \text { Expected } \\ \text { Benefits }(n=12)\end{array} \\ \text { Monetary } & 69 \% & \frac{0}{\text { Benefits }(n=0)} \\ \text { Conservation } & 17 & 0 \\ \text { Comfort } & 14 & 0\end{array}$


TABLE 5.11.8. Benefits Expected by Homeowners Installing Heat Pump Water Heater

\begin{tabular}{|c|c|c|}
\hline \multirow[b]{2}{*}{$\begin{array}{l}\text { Expected } \\
\text { Benefits }\end{array}$} & \multicolumn{2}{|c|}{$\begin{array}{l}\text { Number of Homeowners (in 1000s) } \\
\text { Al? Heating Fuels }(n=12)\end{array}$} \\
\hline & $\begin{array}{c}\text { Received } \\
\text { Expected } \\
\text { Benefits }(n=12)\end{array}$ & $\begin{array}{c}\text { Did Not Receive } \\
\text { Expected } \\
\text { Benefits }(n=0)\end{array}$ \\
\hline Monetary & $69 \%$ & $0 \%$ \\
\hline Conservation & 17 & 0 \\
\hline Comfort & 14 & 0 \\
\hline
\end{tabular}

TABLE 5.12.A. Benefits Expected by Homeowners Installing Wood Stove/Furnace

\begin{tabular}{|c|c|c|}
\hline \multirow[b]{2}{*}{$\begin{array}{l}\text { Expected } \\
\text { Benefits }\end{array}$} & \multicolumn{2}{|c|}{$\begin{array}{r}\text { Number of Homeowners (in 1000s) } \\
\text { Al? Heating Fuels }(n=584)\end{array}$} \\
\hline & $\begin{array}{c}\text { Received } \\
\text { Expected } \\
\text { Benefits }(n=571) \\
\end{array}$ & $\begin{array}{c}\text { Did Not Receive } \\
\text { Expected } \\
\text { Benefits }(n=13) \\
\end{array}$ \\
\hline Monetary & $65 \%$ & $54 \%$ \\
\hline Conservation & 8 & 15 \\
\hline Confort & 28 & 31 \\
\hline
\end{tabular}

TABLE 5.12.B. Benefits Expected by Homeowners Installing Wood Stove/Furnace

\begin{tabular}{lcc} 
& $\begin{array}{c}\text { Number of Homeowners }(i n, 1000 s) \\
\text { All Heating Fuels }(n=3 D 9)\end{array}$ \\
\cline { 2 - 3 } $\begin{array}{c}\text { Expected } \\
\text { Benefits }\end{array}$ & $\begin{array}{c}\text { Expected } \\
\text { Benefits }(n=305)\end{array}$ & $\begin{array}{c}\text { Did Not Receive } \\
\text { Expected }\end{array}$ \\
\hline Monetary & $68 \%$ & $\frac{100 \%}{\text { Conservation }}$ \\
Comfort & 9 & 0
\end{tabular}


TABLE 5.13.A. Benefits Expected by Homeowners Installing Fireplace Inserts

\begin{tabular}{|c|c|c|}
\hline \multirow[b]{2}{*}{$\begin{array}{l}\text { Expected } \\
\text { Benefits } \\
\end{array}$} & \multicolumn{2}{|c|}{$\begin{array}{l}\text { Number of Homeowners (in 1000s) } \\
\text { A1l Heating Fuels }(n=301)\end{array}$} \\
\hline & $\begin{array}{c}\text { Received } \\
\text { Expected } \\
\text { Benefits }(n=282)\end{array}$ & $\begin{array}{c}\text { Did Not Receive } \\
\text { Expected } \\
\text { Benefits }(n=20)\end{array}$ \\
\hline Monetary & $54 \%$ & $58 \%$ \\
\hline Conservation & 13 & 16 \\
\hline Comfort & 33 & 26 \\
\hline
\end{tabular}

TABLE 5.13.B. Benefits Expected by Homeowners Installing Fireplace Inserts

\begin{tabular}{|c|c|c|}
\hline \multirow[b]{2}{*}{$\begin{array}{l}\text { Expected } \\
\text { Benefits }\end{array}$} & \multicolumn{2}{|c|}{$\begin{array}{r}\text { Number of Homeowners (in 1000s) } \\
\text { Ali Heating Fuels }(n=172)\end{array}$} \\
\hline & $\begin{array}{l}\text { Received } \\
\text { Expected } \\
\text { Benefits }(n=155)\end{array}$ & $\begin{array}{l}\text { Did Not Receive } \\
\text { Expected } \\
\text { Benefits }(n=16)\end{array}$ \\
\hline Monetary & $53 \%$ & $69 \%$ \\
\hline Conservation & 20 & 0 \\
\hline Comf ort & 27 & 31 \\
\hline
\end{tabular}

IABLE 5.14.A. Benefits Expected from Weatherproofing. According to Date of Installation

\begin{tabular}{|c|c|c|}
\hline \multirow[b]{2}{*}{$\begin{array}{l}\text { Expected } \\
\text { Benefits }\end{array}$} & \multicolumn{2}{|c|}{$\begin{array}{c}\text { Number of Homeowners (in 1000s) } \\
\text { Al? Heat } i n g \text { Fuels }(n=1,127)\end{array}$} \\
\hline & $\begin{array}{l}\text { Installed } \\
\text { Within the Last } \\
\text { Two Years }(n=613) \\
\end{array}$ & $\begin{array}{l}\text { Installed More } \\
\text { Than Two Years } \\
\text { Ago but Since } \\
\text { the Respondent } \\
\text { Moved in }(n=514)\end{array}$ \\
\hline Monetary & $48 \%$ & $51 \%$ \\
\hline Conservation & 14 & 14 \\
\hline Comfort & 38 & 36 \\
\hline
\end{tabular}


TABLE 5.14.B. Benefits Expected from Weatherproofing, According to Date of Installation

\begin{tabular}{|c|c|c|}
\hline \multirow[b]{2}{*}{$\begin{array}{l}\text { Expected } \\
\text { Benefits }\end{array}$} & \multicolumn{2}{|c|}{$\begin{array}{l}\text { Number of Homeowners (in 1000s) } \\
\text { All theating Fuels }(n=661)\end{array}$} \\
\hline & $\begin{array}{l}\text { Installed } \\
\text { Within the Last } \\
\text { Two Years }(n=341)\end{array}$ & $\begin{array}{l}\text { Installed More } \\
\text { Than Ywo Years } \\
\text { Ago but Since } \\
\text { the Respondent } \\
\text { Moved in }(n=320)\end{array}$ \\
\hline Monetary & $53 \%$ & $55 \%$ \\
\hline Conservation & 15 & 13 \\
\hline Comfort & 32 & 32 \\
\hline
\end{tabular}

TABLE 5.15.A. Benefits Expected from Storm Windows, According to Date of Installation

\begin{tabular}{|c|c|c|}
\hline \multirow[b]{2}{*}{$\begin{array}{l}\text { Expected } \\
\text { Benefits }\end{array}$} & \multicolumn{2}{|c|}{$\begin{array}{l}\text { Number of Homeowners (in 1000s) } \\
\text { All Heating Fuels }(n=822)\end{array}$} \\
\hline & $\begin{array}{l}\text { Installed } \\
\text { Within the Last } \\
\text { Two Years }(n=297) \\
\end{array}$ & $\begin{array}{l}\text { Installed More } \\
\text { Than Two Years } \\
\text { Ago but Since } \\
\text { the Respondent } \\
\text { Moved in ( } n=525)\end{array}$ \\
\hline Monetary & $41 \%$ & $43 \%$ \\
\hline Conservation & 12 & 12 \\
\hline Comfort & 48 & 45 \\
\hline
\end{tabular}

TABLE 5.15.B. Benefits Expected from Storm Windows, According to Date of Instaliation

\begin{tabular}{|c|c|c|}
\hline \multirow[b]{2}{*}{$\begin{array}{l}\text { Expected } \\
\text { Benefits }\end{array}$} & \multicolumn{2}{|c|}{$\begin{array}{r}\text { Number of Homeowners }(\text { in } 1000 s) \\
\text { All Heating Fuels }(n=469)\end{array}$} \\
\hline & $\begin{array}{l}\text { Installed } \\
\text { Within the Last } \\
\text { Two Years }(n=163)\end{array}$ & $\begin{array}{l}\text { Installed More } \\
\text { Than Two Years } \\
\text { Ago but Since } \\
\text { the Respondent } \\
\text { Moved in }(n=306)\end{array}$ \\
\hline Monetary & $42 \%$ & $44 \%$ \\
\hline Conservation & 9 & 12 \\
\hline Comfort & 49 & 44 \\
\hline
\end{tabular}


TABLE 5.16.A. Benefits Expected from Heat Pump Furnace, According to Date of Installation

\begin{tabular}{|c|c|c|}
\hline \multirow[b]{2}{*}{$\begin{array}{l}\text { Expected } \\
\text { Benefits }\end{array}$} & \multicolumn{2}{|c|}{$\begin{array}{c}\text { Number of Homeowners (in 1000s) } \\
\text { AIl Heating Fuels ( } n=95)\end{array}$} \\
\hline & \begin{tabular}{l}
\multicolumn{2}{c}{ Installed } \\
Within the Last \\
Two Years $(n=17)$
\end{tabular} & $\begin{array}{l}\text { Installed More } \\
\text { Than Two Years } \\
\text { Ago but Since } \\
\text { the Respondent } \\
\text { Hoved in }(n=78)\end{array}$ \\
\hline Monetary & $73 \%$ & $74 \%$ \\
\hline Conservation & 27 & 7 \\
\hline Comfort & D & 19 \\
\hline
\end{tabular}

TABLE 5.16.B. Benefits Expected from Heat Pump Furnace, According to Date of Installation

\begin{tabular}{|c|c|c|}
\hline \multirow[b]{2}{*}{$\begin{array}{l}\text { Expected } \\
\text { Benefits }\end{array}$} & \multicolumn{2}{|c|}{$\begin{array}{l}\text { Number of Homeowners (in 1000s) } \\
\text { Al! Heating Fuels }(n=91)\end{array}$} \\
\hline & $\begin{array}{l}\text { Installed } \\
\text { Within the Last } \\
\text { Two Years }(n=17)\end{array}$ & $\begin{array}{l}\text { Insta]led More } \\
\text { Than Two Years } \\
\text { Ago but Since } \\
\text { the Respondent } \\
\text { Moved in }(n=74)\end{array}$ \\
\hline Monetary & $73 \%$ & $76 \%$ \\
\hline Conservation & 27 & 7 \\
\hline Comfort & 0 & 17 \\
\hline
\end{tabular}

TABLE 5.17.A. Benefits Expected from Automatic Setback Thermostat, According to Date of Installation

\begin{tabular}{|c|c|c|}
\hline \multirow[b]{2}{*}{$\begin{array}{l}\text { Expected } \\
\text { Benefits }\end{array}$} & \multicolumn{2}{|c|}{$\begin{array}{r}\text { Number of Homeowners (in 1000s) } \\
\text { All Heating Fuels }(n=301)\end{array}$} \\
\hline & $\begin{array}{l}\text { Installed } \\
\text { Within the Last } \\
\text { Two Years }(n=101) \\
\end{array}$ & $\begin{array}{l}\text { Installed More } \\
\text { Tnan Two Years } \\
\text { Ago but Since } \\
\text { the Respondent } \\
\text { Moved in }(n=20 I)\end{array}$ \\
\hline Monetary & $56 \%$ & $58 \%$ \\
\hline Conservation & 5 & 14 \\
\hline Comfort & 39 & 29 \\
\hline
\end{tabular}


TABLE 5.17.8. Benefits Expected from Automatic Setback Thermostat, According to Date of installation

\begin{tabular}{|c|c|c|}
\hline \multirow[b]{2}{*}{$\begin{array}{l}\text { Expected } \\
\text { Benefits }\end{array}$} & \multicolumn{2}{|c|}{$\begin{array}{l}\text { Number of Homeowners (in 1000s) } \\
\text { A11 Heat ing Fuels }(n=157)\end{array}$} \\
\hline & $\begin{array}{l}\text { Installed } \\
\text { Within the Last } \\
\text { Iwo Years }(n=58)\end{array}$ & $\begin{array}{l}\text { Installed More } \\
\text { Than Two Years } \\
\text { Ago but Since } \\
\text { the Respondent } \\
\text { Moved in (n=99) }\end{array}$ \\
\hline Monetary & $52 \%$ & $49 \%$ \\
\hline Conservation & 0 & 13 \\
\hline Comfort & 48 & 38 \\
\hline
\end{tabular}

TABLE 5.18.A. Benefits Expected from Insulating Basement floor or Crawispace, According to Oate of Installation

\begin{tabular}{|c|c|c|}
\hline \multirow[b]{2}{*}{$\begin{array}{l}\text { Expected } \\
\text { Benefits }\end{array}$} & \multicolumn{2}{|c|}{$\begin{array}{r}\text { Number of Homeowners (in 1000s) } \\
\text { All Heating Fuels }(n=584)\end{array}$} \\
\hline & $\begin{array}{l}\text { Insulated } \\
\text { Within the Last } \\
\text { Two Years }(n=200)\end{array}$ & $\begin{array}{l}\text { Insulated More } \\
\text { Than Two Years } \\
\text { Ago but Since } \\
\text { the Respondent } \\
\text { Moved in }(n=384)\end{array}$ \\
\hline Monetary & $35 \%$ & $34 \%$ \\
\hline Conservation & 14 & 12 \\
\hline Comfort & 50 & 54 \\
\hline
\end{tabular}

TABLE 5.18.8. Benefits Expected from Insulating Basement Floor or Crawlspace, According to Oate of Installation

\begin{tabular}{|c|c|c|}
\hline \multirow[b]{2}{*}{$\begin{array}{l}\text { Expected } \\
\text { Benefits }\end{array}$} & \multicolumn{2}{|c|}{$\begin{array}{r}\text { Number of Homeowners }(\text { in } 1000 \mathrm{~s}) \\
\text { All Heating Fuels }(n=389)\end{array}$} \\
\hline & $\begin{array}{c}\text { Insulated } \\
\text { Within the Last } \\
\text { Two Years }(n=146) \\
\end{array}$ & $\begin{array}{l}\text { Insulazed More } \\
\text { Than Two Years } \\
\text { Ago but Since } \\
\text { the Respondent } \\
\text { Moved in }(n=243) \\
\end{array}$ \\
\hline Monetary & $32 \%$ & $31 \%$ \\
\hline Conservation & 12 & 14 \\
\hline Comfort & 55 & 55 \\
\hline
\end{tabular}


TABLE 5.19.A. Benefits Expected from Insulating Outside Walls, According to Date of Installation

\begin{tabular}{lcc} 
& $\begin{array}{r}\text { Number of Homeowners } \\
\text { All Heating Fuels }(n=479)\end{array}$ \\
\cline { 2 - 3 } $\begin{array}{c}\text { Expected } \\
\text { Benefits }\end{array}$ & $\begin{array}{c}\text { Insulated More } \\
\text { Within the Last } \\
\text { Twan Two Years } \\
\text { Two Years }(n=125)\end{array}$ & $\begin{array}{c}\text { Ago but Since } \\
\text { the Respondent } \\
\text { Moved in }(n=354)\end{array}$ \\
\cline { 2 - 3 } $\begin{array}{l}\text { Monetary } \\
\text { Conservation }\end{array}$ & $36 \%$ & $36 \%$ \\
Comfort & 11 & 17 \\
& 53 & 47
\end{tabular}

TABLE 5.19.8. Benefits Expected from Insulating Outside Walls, According to Oate of Installation

\begin{tabular}{|c|c|c|}
\hline \multirow[b]{2}{*}{$\begin{array}{l}\text { Expected } \\
\text { Benefits }\end{array}$} & \multicolumn{2}{|c|}{$\begin{array}{r}\text { Number of Homeowners (in 1000s) } \\
\text { AI Heating Fuels }(n=252)\end{array}$} \\
\hline & $\begin{array}{l}\text { Insulated } \\
\text { Within the Last } \\
\text { Two Years (n=80) }\end{array}$ & $\begin{array}{l}\text { Insulated More } \\
\text { Than Two Years } \\
\text { Ago but Since } \\
\text { the Respondent } \\
\text { Moved in }(n=172)\end{array}$ \\
\hline Monetary & $30 \%$ & $36 \%$ \\
\hline Conservation & 12 & 13 \\
\hline Comfort & 57 & 51 \\
\hline
\end{tabular}

TABLE 5.20.A. Benefits Expected from Insulating Roof or Attic, According to Date of Installation

\begin{tabular}{|c|c|c|}
\hline \multirow[b]{2}{*}{$\begin{array}{l}\text { Expected } \\
\text { Benefits }\end{array}$} & \multicolumn{2}{|c|}{$\begin{array}{r}\text { Number of Homeowners (in 1000s) } \\
\text { Al? Heating Fuels }(n=814)\end{array}$} \\
\hline & $\begin{array}{l}\text { Insulated } \\
\text { Within the Last } \\
\text { Two Years }(n=248) \\
\end{array}$ & $\begin{array}{l}\text { Insulaced More } \\
\text { Tinan Two Years } \\
\text { Ago but Since } \\
\text { the Respondent } \\
\text { Moved in }(n=566)\end{array}$ \\
\hline Monetary & $39 \%$ & $38 \%$ \\
\hline Conservation & 12 & 16 \\
\hline Comfort & 49 & 45 \\
\hline
\end{tabular}


TABLE 5.20.B. Benefits Expected from Insulating Roof or Attic, According to Date of installation

\begin{tabular}{|c|c|c|}
\hline \multirow[b]{2}{*}{$\begin{array}{l}\text { Expected } \\
\text { Benefits }\end{array}$} & \multicolumn{2}{|c|}{$\begin{array}{l}\text { Number of Homeowners (in 1000s) } \\
\text { All Heating Fuels }(n=473)\end{array}$} \\
\hline & $\begin{array}{l}\text { Insulated } \\
\text { Within the Last } \\
\text { Two Years }(n=175)\end{array}$ & $\begin{array}{l}\text { Insulated More } \\
\text { Than Two Years } \\
\text { Ago but Since } \\
\text { the Respondent } \\
\text { Moved in ( } n=298)\end{array}$ \\
\hline Monetary & $42 \%$ & $36 \%$ \\
\hline Conservation & 11 & 15 \\
\hline Comfort & 47 & 49 \\
\hline
\end{tabular}

TABLE 5.21.A. Benefits Expected from Solar Panels, According to Date of Installation

\begin{tabular}{|c|c|c|}
\hline \multirow[b]{2}{*}{$\begin{array}{l}\text { Expected } \\
\text { Benefits }\end{array}$} & \multicolumn{2}{|c|}{$\begin{array}{l}\text { Number of Homeowners (in 1000s) } \\
\text { All Heating Fuels ( } n=32)\end{array}$} \\
\hline & $\begin{array}{l}\text { Installed } \\
\text { Within the Last } \\
\text { Two Years }(n=12)\end{array}$ & $\begin{array}{l}\text { Installed More } \\
\text { Than Two Years } \\
\text { Ago but Since } \\
\text { the Respondent } \\
\text { Moved in }(n=21)\end{array}$ \\
\hline Monetary & $60 \%$ & $41 \%$ \\
\hline Conservation & 40 & 60 \\
\hline Comfort & 0 & 0 \\
\hline
\end{tabular}

TABLE 5.21.B. Benefits Expected from Solar Panels, According to Date of Installation

\begin{tabular}{|c|c|c|}
\hline \multirow[b]{2}{*}{$\begin{array}{l}\text { Expected } \\
\text { Benefits }\end{array}$} & \multicolumn{2}{|c|}{$\begin{array}{l}\text { Number of Homeowners (in 1000s) } \\
\text { All Heating Fuels }(n=23)\end{array}$} \\
\hline & $\begin{array}{l}\text { Instalied } \\
\text { Within the Last } \\
\text { Two Years }(n=9)\end{array}$ & $\begin{array}{l}\text { Installed More } \\
\text { Than Two Years } \\
\text { Ago but Since } \\
\text { the Respondent } \\
\text { Moved in }(n=14)\end{array}$ \\
\hline Monetary & $51 \%$ & $46 \%$ \\
\hline Conservation & 49 & 54 \\
\hline Comfort & 0 & 0 \\
\hline
\end{tabular}


TABLE 5.22.A. Benefits Expected from Storm/Insulated Doors, According to Date of Installation

\begin{tabular}{|c|c|c|}
\hline \multirow[b]{2}{*}{$\begin{array}{l}\text { Expected } \\
\text { Benefits }\end{array}$} & \multicolumn{2}{|c|}{$\begin{array}{c}\text { Number of Homeowners (in 1000s) } \\
\text { AT? Heating Fuels }(n=629)\end{array}$} \\
\hline & $\begin{array}{l}\text { Installed } \\
\text { Within the Last } \\
\text { Two Years }(n=207) \\
\end{array}$ & $\begin{array}{l}\text { Installed More } \\
\text { Than Two Years } \\
\text { Ago but Since } \\
\text { the Respondent } \\
\text { Moved in ( } n=422)\end{array}$ \\
\hline Monetary & $26 \%$ & $24 \%$ \\
\hline Conservation & 18 & 15 \\
\hline Comfort & 57 & 61 \\
\hline
\end{tabular}

TABLE 5.22.B. Benefits Expected from Storm/Insulated Doors, According to Date of Installation

\begin{tabular}{|c|c|c|}
\hline \multirow[b]{2}{*}{$\begin{array}{l}\text { Expected } \\
\text { Benefits }\end{array}$} & \multicolumn{2}{|c|}{$\begin{aligned} \text { Number of Homeowners }(i n \text { 1000s) } & \\
\text { All Heating Fueis } & (n=350)\end{aligned}$} \\
\hline & $\begin{array}{c}\text { Installed } \\
\text { Within the Last } \\
\text { Two Years }(n=124) \\
\end{array}$ & $\begin{array}{l}\text { Installed More } \\
\text { Than Two Years } \\
\text { Ago but Since } \\
\text { the Respondent } \\
\text { Moved in }(n=226)\end{array}$ \\
\hline Monetary & $30 \%$ & $27 \%$ \\
\hline Conservation & 19 & 16 \\
\hline Comfort & 51 & 57 \\
\hline
\end{tabular}

TABLE 5.23.A. Benefits Expected from Heat Pump Water Heater, According to Date of Installation

\begin{tabular}{|c|c|c|}
\hline \multirow[b]{2}{*}{$\begin{array}{l}\text { Expected } \\
\text { Benefits }\end{array}$} & \multicolumn{2}{|c|}{$\begin{array}{r}\text { Number of Homeowners (in 1000s) } \\
\text { Ail Heating Fuels }(n=14)\end{array}$} \\
\hline & $\begin{array}{l}\text { Installed } \\
\text { Within the Last } \\
\text { Two Years }(n=4)\end{array}$ & $\begin{array}{l}\text { Installed More } \\
\text { Than Two Years } \\
\text { Ago but Since } \\
\text { the Respondent } \\
\text { Moved in }(n=10)\end{array}$ \\
\hline Monetary & $0 \%$ & $83 \%$ \\
\hline Conservation & 50 & 0 \\
\hline Comfort & 50 & 17 \\
\hline
\end{tabular}


TABLE 5.23.B. Benefits Expected from Heat Pump Water Heater, According to Date of Installation

\begin{tabular}{|c|c|c|}
\hline \multirow[b]{2}{*}{$\begin{array}{l}\text { Expected } \\
\text { Benefits }\end{array}$} & \multicolumn{2}{|c|}{$\begin{array}{r}\text { Number of Homeowners (in 1000s) } \\
\text { All Heating Fuels }(n=14)\end{array}$} \\
\hline & $\begin{array}{l}\text { Installed } \\
\text { Within the Last } \\
\text { Two Years }(n=4) \\
\end{array}$ & $\begin{array}{l}\text { Installed More } \\
\text { Than Two Years } \\
\text { Ago but Since } \\
\text { the Respondent } \\
\text { Moved in }(n=10)\end{array}$ \\
\hline Monetary & $D \%$ & $83 \%$ \\
\hline Conservation & 50 & 0 \\
\hline Comfort & 50 & 17 \\
\hline
\end{tabular}

TABLE 5.24.A. Benefits Expected from Wood Stove/Furnace, According to Date of Installation

\begin{tabular}{|c|c|c|}
\hline \multirow[b]{2}{*}{$\begin{array}{l}\text { Expected } \\
\text { Benefits }\end{array}$} & \multicolumn{2}{|c|}{$\begin{array}{r}\text { Number of Homeowners (in 1000s) } \\
\text { Ail Heating Fuels }(n=594)\end{array}$} \\
\hline & $\begin{array}{l}\text { Installed } \\
\text { Within the Last } \\
\text { Two Years }(n=157)\end{array}$ & $\begin{array}{l}\text { Installed More } \\
\text { Than Two Years } \\
\text { Ago but Since } \\
\text { the Respondent } \\
\text { Moved in }(n=437)\end{array}$ \\
\hline Monetary & $68 \%$ & $64 \%$ \\
\hline Conservation & 9 & 7 \\
\hline Comfort & 23 & 29 \\
\hline
\end{tabular}

TABLE 5.24.B. Benefits Expected from Wood Stove/Furnace, According to Date of Installation

\begin{tabular}{lcc} 
& $\begin{array}{r}\text { Number of Homeowners }(\text { in 1000s }) \\
\text { All Heating Fuels }(n=319)\end{array}$ \\
\cline { 2 - 3 } $\begin{array}{c}\text { Expected } \\
\text { Benefits }\end{array}$ & $\begin{array}{c}\text { Instalied } \\
\text { Within the Last } \\
\text { Two Years }(n=110)\end{array}$ & $\begin{array}{c}\text { Ago but Since } \\
\text { the Respondent } \\
\text { Moved in }(n=209)\end{array}$ \\
\cline { 2 - 3 } Monetary & $63 \%$ & $71 \%$ \\
Conservation & 11 & 7 \\
Comfort & 27 & 21
\end{tabular}


TABLE 5.25.A. Benefits Expected from Fireplace Insert, According to Date of Installation

\begin{tabular}{|c|c|c|}
\hline \multirow[b]{2}{*}{$\begin{array}{l}\text { Expected } \\
\text { Benefits }\end{array}$} & \multicolumn{2}{|c|}{$\begin{array}{r}\text { Number of Homeowners (in 1000s) } \\
\text { All Heating Fuels }(n=311)\end{array}$} \\
\hline & $\begin{array}{l}\text { Installed } \\
\text { Within the Last } \\
\text { Two Years }(n=66)\end{array}$ & $\begin{array}{l}\text { Installed More } \\
\text { Than Two Years } \\
\text { Ago but Since } \\
\text { the Respondent } \\
\text { Moved in ( } n=245)\end{array}$ \\
\hline Monetary & $59 \%$ & $53 \%$ \\
\hline Conservation & 19 & 11 \\
\hline Comfort & 22 & 36 \\
\hline
\end{tabular}

TABLE 5.25.B. Benefits Expected from Fireplace Insert, According to Date of Insta?lation

\begin{tabular}{|c|c|c|}
\hline \multirow[b]{2}{*}{$\begin{array}{l}\text { Expected } \\
\text { Benefits }\end{array}$} & \multicolumn{2}{|c|}{$\begin{array}{r}\text { Number of Homeowners (in 1000s) } \\
\text { Al i Heating Fuels }(n=179)\end{array}$} \\
\hline & $\begin{array}{l}\text { Installed } \\
\text { Within the Last } \\
\text { Two Years }(n=50)\end{array}$ & $\begin{array}{l}\text { Installed More } \\
\text { Than Two Years } \\
\text { Ago but Since } \\
\text { the Respondent } \\
\text { Moved in }(n=129)\end{array}$ \\
\hline Monetary & $63 \%$ & $51 \%$ \\
\hline Conservation & 21 & 16 \\
\hline Comfort & 17 & 33 \\
\hline
\end{tabular}




\subsection{DEMOGRAPHIC INFLUENCES ON PAST AND FUTURE ENERGY CONSERVATION BEHAVIOR}

Knowledge of the demographic profile of Northwest homeowners and of its effect on behavior and intentions of homeowners concerned about energy conservation is important to the present study. This knowledge can help to identify consumer segments of interest. The objective of this chapter is to test a hypothesis using demographic variables. This hypothesis states that consumer behavior and intentions toward conservation will not vary by demographically defined groups. The demographic variables used are the following: length of time at current residence, number of occupants in residence, occupation of the respondent or primary householder, occupation of the second householder, educational level of householder, total household income, and geographic location of the residence (j.e., survey quadrant). These variables are typical of the demographic variables used in market research studies.

\subsection{DEMOGRAPHIC INFLUENCES ON ENERGY CONSERVATION BEHAVIOR}

Each of the demographic variables was run in a crosstab with the number of energy conservation measures homeowners indicated they had installed. The demographic variables represent the independent variables. The number of ECMs installed by current occupants represents the dependent variable. The dependent varizble has four activity levels: low level = 0 to 1 ECMs installed, medium low $=2$ to 4 installed, medium high $=5$ to 7 installed, and high level = $8+$ ECMs instalied.

\subsubsection{Length of Time at Current Residence}

Tabies 6.1.A and 6.1.B reveal that length of time in a residence has an effect on the number of ECMs installed (see Tables 6.1.A and 6.1.B). Thus, the longer a resident occupies a home, the more likeily he is to invest in ECMs. For example, about $60 \%$ of those living in a home for two years or less had installed 0 to 1 ECM, while approximately $25 \%$ of those living in a home for five or more years had installed only 0 to $1 \mathrm{ECM}$. This effect from length of time is not surprising and is consistent at the low end of the installation activity scale. The effect is less consistent at the medium-low (2 to 4 ) and medium-high ( 5 to 7 ) activity levels. The data becomes inconsistent at the 
TABLE 6.1.A. Number of Energy Conservation Measures Installed by Current Homeowners, by Length of Time at Current Residence

\begin{tabular}{|c|c|c|c|c|}
\hline \multirow{2}{*}{$\begin{array}{l}\text { Number of } \\
\text { Energy } \\
\text { Conservation } \\
\text { Measures } \\
\text { Installed } \\
\text { by Current } \\
\text { Homeowners }\end{array}$} & \multicolumn{4}{|c|}{$\begin{array}{l}\text { Number of Homeowners (in 1000s) } \\
\text { Al? Heating Fuels ( } n=2148) \\
\text { Length of Time at Current Address }\end{array}$} \\
\hline & $\begin{array}{l}\text { Under } \\
1 \text { Year } \\
(n=268) \\
\end{array}$ & $\begin{array}{c}1-2 \\
\text { Years } \\
(n=153) \\
\end{array}$ & $\begin{array}{r}3-4 \\
\text { Years } \\
(n=236) \\
\end{array}$ & $\begin{array}{l}\text { Over } \\
5 \text { Years } \\
(n=1492) \\
\end{array}$ \\
\hline $0-1$ & $57 \%$ & $61 \%$ & $49 \%$ & $25 \%$ \\
\hline $2-4$ & 24 & 25 & 35 & 41 \\
\hline $5-7$ & 15 & 14 & 17 & 30 \\
\hline $8+$ & 3 & 0 & 0 & 4 \\
\hline
\end{tabular}

TABLE 6.1.B. Number of Energy Conservation Measures Installed by Current Homeowners, by Length of Time at Current Residence

\begin{tabular}{|c|c|c|c|c|}
\hline \multirow{2}{*}{$\begin{array}{l}\text { Number of } \\
\text { Energy } \\
\text { Conservation } \\
\text { Measures } \\
\text { Installed } \\
\text { by Current } \\
\text { Homeowners }\end{array}$} & \multicolumn{4}{|c|}{$\begin{array}{l}\text { Number of Homeowners (in 1000s) } \\
\text { Heating Fuel Electric }(n=1261) \\
\text { Length of Time at Current Address }\end{array}$} \\
\hline & $\begin{array}{r}\text { Under } \\
\text { Year } \\
(n=186) \\
\end{array}$ & $\begin{array}{r}1-2 \\
\text { Years } \\
(n=89) \\
\end{array}$ & $\begin{array}{c}3-4 \\
\text { Years } \\
(n=144) \\
\end{array}$ & $\begin{array}{l}\text { Over } \\
5 \text { Years } \\
(\mathrm{n}=842) \\
\end{array}$ \\
\hline $0-1$ & $55 \%$ & $64 \%$ & $41 \%$ & $27 \%$ \\
\hline $2-4$ & 21 & 25 & 37 & 39 \\
\hline $5-7$ & 19 & 11 & 22 & 30 \\
\hline $8+$ & 5 & 0 & 0 & 4 \\
\hline
\end{tabular}

high (8+) level of activity both for the entire set of homeowners and for those using eiectric heat. The data from Tables 6.1.A or 6.1.B indicate that after initial construction or a move to a new home, very few homeowners install enough additional ECMs to achieve the high activity level. The data also suggest that if the household does not have eight or more ECMs installed in the first yea., the homeowner is not likely to reach the high activity level in the future. Thus, failing to take advantage of conservation measures in the first year of ownership may represent a lost opportunity. BPA conservation programs, aimed at homeowners, should place special emphasis on ECM installation in the construction phase of new homes. 


\subsubsection{Number of Occupants in Residence}

The second demographic variable of interest is the total number of occupants in a residence. The number of occupants in a home appears to be positively related to the level of installation activity; as the number of occupants increases, so does the level of installation activity (see Table 6.2.A). Approximately 45\% of residents living alone had installed 0 to 1 ECM, while only $28 \%$ of the homes with six or more occupants fell into the low activity level. Number of occupants has approximately the same effect on installation activity at the medium-high to high levels. For example, only $21 \%$ of homes with one occupant had installed at least five ECMs compared with 35\% of the homes with six or more people. The subset of homeowners with electric heat demonstrated similar behavior as is shown in Table 6.2 .8 , with $44 \%$ of those living alone falling in the low installation activity level and only $34 \%$ of homes with six or more occupants falling into the low activity level. On the other hand, $21 \%$ of the single-occupant electrically heated homes have installed at least 5 ECMs while 38\% of the 6 or more person households using electric heat have installed at least 5 ECMs.

The direction of the relationship of number of occupants to number of ECMs installed is easily observable at the extremes, especially with the subset of homeowners using electric heat. The relationship is not so obvious when

TABLE 6.2.A. Number of Energy Conservation Measures Installed by Current occupants, by Number of Occupants Including the Homeowner

\begin{tabular}{|c|c|c|c|c|c|c|}
\hline \multirow{2}{*}{$\begin{array}{l}\text { Number of } \\
\text { Energy } \\
\text { Conservation } \\
\text { Measures } \\
\text { Installed } \\
\text { by Current } \\
\text { Occupants } \\
\end{array}$} & \multicolumn{6}{|c|}{$\begin{array}{l}\text { Number of Homeowners (in 1000s) } \\
\text { A1l Heating Fuels (n=2150) } \\
\text { Number of Occupants Including Homeowner }\end{array}$} \\
\hline & $(n=307)$ & $\begin{array}{c}2 \\
(n=746) \\
\end{array}$ & $\begin{array}{c}3 \\
(n=383) \\
\end{array}$ & $\begin{array}{c}4 \\
(n=404) \\
\end{array}$ & $\begin{array}{c}5 \\
(n=181) \\
\end{array}$ & $\begin{array}{c}6 \text { or more } \\
(n=128)\end{array}$ \\
\hline $0-1$ & $45 \%$ & $31 \%$ & $33 \%$ & $33:$ & $36 \%$ & $28 \%$ \\
\hline $2-4$ & 34 & 38 & 35 & 39 & 40 & 37 \\
\hline $5-7$ & 21 & 26 & 27 & 28 & 23 & 28 \\
\hline $8+$ & 0 & 4 & 6 & 0 & 1 & 7 \\
\hline
\end{tabular}


TABLE 6.2.B. Number of Energy Conservation Measures Installed by Current Occupants, by Number of Occupants Including the Homeowner

\begin{tabular}{|c|c|c|c|c|c|c|}
\hline \multirow{2}{*}{$\begin{array}{l}\text { Number of } \\
\text { Energy } \\
\text { Conservation } \\
\text { Measures } \\
\text { Installed } \\
\text { by Current } \\
\text { Occupants } \\
\end{array}$} & \multicolumn{6}{|c|}{$\begin{array}{l}\text { Number of Homeowners (in 1000s) } \\
\text { Heating Fuel Electric ( } n=1262) \\
\text { Number of Occupants Including Homeowner }\end{array}$} \\
\hline & $\begin{array}{c}1 \\
\langle n=185 \\
\end{array}$ & $\begin{array}{c}2 \\
(n=430) \\
\end{array}$ & $\begin{array}{c}3 \\
(n=232)\end{array}$ & $\begin{array}{c}4 \\
(n=210)\end{array}$ & $\begin{array}{c}5 \\
(n=118) \\
\end{array}$ & $\begin{array}{c}5 \text { or more } \\
(n=88)\end{array}$ \\
\hline $0-1$ & $44 \%$ & $35 \%$ & $35 \%$ & $33 \%$ & $32 \%$ & $34 \%$ \\
\hline $2-4$ & 34 & 34 & 36 & 35 & 41 & 29 \\
\hline $5-7$ & 21 & 27 & 22 & 31 & 25 & 28 \\
\hline $8+$ & 0 & 4 & 7 & 0 & 2 & 10 \\
\hline
\end{tabular}

looking at homes with either 4 or 5 occupants. Although the activity breakdown of homes with $1,2,3$ and $6+$ occupants supports the conclusion that ECM installation increases with number of occupants, installation activity in homes with either 4 or 5 occupants does not. Perhaps other demographic variables influence the latter relationship.

\subsubsection{Occupation of the Homeowner}

The third demographic variable is the occupation of the homeowner, or the respondent/primary householder. The categories for occupation are professional, executive-administrative-managerial, clerical-sales-technical, craftsforeman, and other employed (see Table 6.3.A). A]though 30\% of those in the professional and clerical-sales-technical categories had installed five or more ECMs, the groups differ in how they reached the $30 \%$ mark. The difference is best illustrated by group breakdown at the high activity level. In the professional category, 4\% had installed eight or more ECMs, while in the clericalsales-technical category, only 1\% had installed that number. For homes using electric heat, the percentages in those same categories were nearly duplicated (see Tabie 6.3.B).

The occupational groups with the lowest percentages in the medium-high to high activity levels were the other employed group and the executiveadministrative-managerial group. Oniy $23 \%$ from these groups had installed five or more ECMs. Members of these occupational groups are the least likely to 
TABLE 6.3.A. Number of Energy Conservation Measures Installed by Current Occupants, by Occupation of the Homeowner

\begin{tabular}{|c|c|c|c|c|c|}
\hline \multirow{2}{*}{$\begin{array}{l}\text { Number of } \\
\text { Energy } \\
\text { Conservation } \\
\text { Measures } \\
\text { Installed } \\
\text { by Current } \\
\text { Occupants } \\
\end{array}$} & \multicolumn{5}{|c|}{$\begin{array}{c}\text { Number of Homeowners (in 1000s) } \\
\text { All Heating Fuels ( } n=1375 \text { ) } \\
\text { Occupation of Homeowner }\end{array}$} \\
\hline & $\begin{array}{l}\text { Professional } \\
(n=370) \\
\end{array}$ & $\begin{array}{l}\text { Executive } \\
\text { Administrative } \\
\text { Managerial } \\
(n=220) \\
\end{array}$ & $\begin{array}{l}\text { CTerical } \\
\text { Sales } \\
\text { Technician } \\
(n=329) \\
\end{array}$ & $\begin{array}{l}\text { Crafts } \\
\text { Foreman } \\
(n=148) \\
\end{array}$ & $\begin{array}{l}\text { Other } \\
\text { Employed } \\
\text { (n=308) }\end{array}$ \\
\hline $0-1$ & $35 \%$ & $33 \%$ & $33 \%$ & $26 \%$ & $34 \%$ \\
\hline $2-4$ & 34 & 43 & 37 & 49 & 43 \\
\hline $5-7$ & 27 & 21 & 30 & 27 & 20 \\
\hline $8+$ & 4 & 2 & 1 & 0 & 3 \\
\hline
\end{tabular}

TABLE 6.3.B. Number of Energy Conservation Measures Installed by Current Occupants, by Occupation of the Homeowner

\begin{tabular}{|c|c|c|c|c|c|}
\hline \multirow{2}{*}{$\begin{array}{l}\text { Number of } \\
\text { Energy } \\
\text { Conservation } \\
\text { Measures } \\
\text { Installed } \\
\text { by Current } \\
\text { Occupants }\end{array}$} & \multicolumn{5}{|c|}{$\begin{array}{c}\text { Number of Homeowners (in 1000s) } \\
\text { Heating Fuel Electric }(n=780) \\
\text { Occupation of Homeowner }\end{array}$} \\
\hline & $\begin{array}{l}\text { Professional } \\
(n=194) \\
\end{array}$ & $\begin{array}{c}\text { Executive } \\
\text { Administrative } \\
\text { Managerial } \\
(n=128) \\
\end{array}$ & $\begin{array}{c}\text { Clerical } \\
\text { Sales } \\
\text { Technician } \\
(n=193) \\
\end{array}$ & $\begin{array}{l}\text { Crafts } \\
\text { Foreman } \\
(n=86) \\
\end{array}$ & $\begin{array}{l}\text { Other } \\
\text { Employed } \\
\text { (n=179) }\end{array}$ \\
\hline $0-1$ & $37 \%$ & $33 \%$ & $31 \%$ & $33 \%$ & $31 \%$ \\
\hline $2-4$ & 31 & 42 & 37 & 47 & 44 \\
\hline $5-7$ & $2 B$ & 21 & 31 & 20 & 22 \\
\hline $8+$ & 4 & 4 & 1 & 0 & 4 \\
\hline
\end{tabular}

install five or more ECMs. At least $27 \%$ of all the other occupational groups did invest in five or more ECMs.

The occupational group breakdowns for the subset of homeowners with electric heat are similar to the breakdowns for the entire sample (see Table 6.3.B). Only one group showed a noticeable change in activity level. The crafts-foreman electric subset is much less active regarding conservation investment than is the entire group of crafts-foreman respondents. Only $20 \%$ of the electric heat subset has installed five or more ECMs down from $27 \%$ for the 
entire sample. Also, the percentage of crafts-foreman at the low installation activity level (0-1 ECMs) increased from $26 \%$ for the whole group to $33 \%$ for the electric heat subset.

Of the five occupational groups, the crafts-foreman group was the least active group with regard to installation of ECMs. The same was true for the entire sample of homeowners as well as for the subset of homeowners with electric heat.

\subsubsection{Occupation of The Second Householder}

The fourth demographic variable of interest is the occupation of the second householder. Occupational groupings are the same as those of the previous section (see Section 6.1.3). The most active household regarding installation of ECMs is the one where the second househoider works in the crafts-foreman occupational group. This high activity, defined as five or more ECMs instalied, was true for all homeowners (See Table 6.4.A) as well as for the subset of homeowners with electric heat. The crafts-foreman group from the electric heat subset had an interesting distribution among the installation activity levels (see Table 6.4.B). This occupational grouping was the most active at the medium-high and high activity levels but also had the largest percentage of respondents at the ievel of lowest activity (0-1 ECM). Two possible explanations are possible for this counter-intuitive distribution across activity levels. First, other research (Dariey and Beniger 1981) suggests that

TABLE 6.4.A. Number of Energy Conservation Measures Installed by Current Occupants, by Occupation of the Second Householder

\begin{tabular}{|c|c|c|c|c|c|}
\hline \multirow{2}{*}{$\begin{array}{l}\text { Number of } \\
\text { Energy } \\
\text { Conservation } \\
\text { Measures } \\
\text { Installed } \\
\text { by Current } \\
\text { Occupants } \\
\end{array}$} & \multicolumn{5}{|c|}{$\begin{array}{l}\text { Number of Homeowners (in 1000s) } \\
\text { All Heating Fuels }(n=1066) \\
\text { Occuoation of the Second Householder }\end{array}$} \\
\hline & $\begin{array}{l}\text { Professiona } \\
(n=298)\end{array}$ & $\begin{array}{l}\text { Executive } \\
\text { Administrative } \\
\text { Managerial } \\
(n=216)\end{array}$ & $\begin{array}{l}\text { Clerical } \\
\text { Sales } \\
\text { Technician } \\
(n=199) \\
\end{array}$ & $\begin{array}{r}\text { Crafts } \\
\text { Foreman } \\
(n=160) \\
\end{array}$ & $\begin{array}{l}\text { Other } \\
\text { Employed } \\
\text { (n=193! }\end{array}$ \\
\hline $0-1$ & $39 \%$ & $30 \%$ & $36 \%$ & $35^{\circ}$ & $43^{\circ}$ \\
\hline $2-4$ & 33 & 46 & 35 & 31 & 27 \\
\hline $5-7$ & 25 & 20 & 30 & 29 & 28 \\
\hline $8+$ & 3 & 3 & 0 & 5 & 2 \\
\hline
\end{tabular}


TABLE 6.4.B. Number of Energy Conservation Measures Installed by Current Occupants, by Occupation of the Second Householder

\begin{tabular}{|c|c|c|c|c|c|}
\hline \multirow{2}{*}{$\begin{array}{l}\text { Number of } \\
\text { Energy } \\
\text { Conservation } \\
\text { Measures } \\
\text { Installed } \\
\text { by Current } \\
\text { Occupants }\end{array}$} & \multicolumn{5}{|c|}{$\begin{array}{l}\text { Number of Homeowners (in 1000s) } \\
\text { Heating Fuel Electric }(n=570) \\
\text { Occupation of the Second Househoider }\end{array}$} \\
\hline & $\begin{array}{l}\text { Professiona? } \\
(n=161) \\
\end{array}$ & $\begin{array}{l}\text { Executive } \\
\text { Administrative } \\
\text { Managerial } \\
(n=100)\end{array}$ & $\begin{array}{l}\text { Clerical } \\
\text { Sales } \\
\text { Technician } \\
(n=116) \\
\end{array}$ & $\begin{array}{l}\text { Crafts } \\
\text { Foreman } \\
(n=75) \\
\end{array}$ & $\begin{array}{l}\text { Other } \\
\text { Employed } \\
(n=117)\end{array}$ \\
\hline $0-1$ & $40 \%$ & $21 \%$ & $42 \%$ & $53 \%$ & $40 \%$ \\
\hline $2-4$ & 26 & 62 & 28 & 10 & 26 \\
\hline $5-7$ & 33 & 11 & 30 & 35 & 30 \\
\hline $8+$ & 2 & 5 & 0 & 2 & 4 \\
\hline
\end{tabular}

an ability to understand and self-install ECMs is favorable with regard to actual installation. This is supported by the crafts-foreman group percentages in the medium-high and high installation activity levels. Second, the current research presents additional data in subsequent tables to show that the subset of homeowners with electric heat tend to have smaller household incomes. This difference in incomes is possibly muted when comparing the income levels of all homeowners, including those with electric heat, with income levels of the electric heat subset. The gap in income would probably widen if the comparison were made strictly between non-electric and electric heating systems. This may be the reason that $53 \%$ of the crafts-foreman group from the electric subset is at the lowest installation activity level while only $35 \%$ of the total sample crafts-foreman group is at this ievel.

The low end of the activity scale was not dominated by any of the occupational groups when observing data from the entire sample. However, for the subset of homeowners with electric heat, one group dominated. In this subset, 83\% of the executive-administrative-managerial occupational group installed no more than four ECMs compared with $63 \%$ to $70 \%$ for the other occupational groups. The same executive-administrative-managerial group also had the highest proportion who installed eight or more ECMs. The reason for this may be partialiy a result of the larger total household income compared with most other occupational groups. 


\subsubsection{Educational Level of Household}

The next demagraphic variable of interest is the highest level of education in the household or, specificaliy, the determination of the effect of education level on ECM installation activity. The educational level of the household was equated to the highest level of education obtained by either the first or second househoider.

The households were broken down into four educational levels as can be seen in Tables 6.5.A and 6.5.B. The first contains households in which the

TABLE 6.5.A. Number of Energy Conservation Measures Installed by Current Occupant, by Education Level of the Household

\begin{tabular}{|c|c|c|c|c|}
\hline \multirow{2}{*}{$\begin{array}{l}\text { Number of } \\
\text { Energy } \\
\text { Conservation } \\
\text { Measures } \\
\text { Installed } \\
\text { by Current } \\
\text { Occupants } \\
\end{array}$} & \multicolumn{4}{|c|}{$\begin{array}{l}\text { Number of Homeowners (in 1000s) } \\
\text { Al) Heating Fuels ( } n=2140) \\
\text { Education Level of the Household }\end{array}$} \\
\hline & $\begin{array}{l}\text { Completed } \\
\text { High School } \\
\text { or Less } \\
(n=763) \\
\end{array}$ & $\begin{array}{l}\text { Completed } \\
\text { Trade/Votech } \\
\text { Some College } \\
\quad(n=661) \\
\end{array}$ & $\begin{array}{l}\text { Completed } \\
\text { Coilege } \\
(n=426) \\
\end{array}$ & $\begin{array}{l}\text { At Least } \\
\text { Some Graduate } \\
\text { School }(n=290)\end{array}$ \\
\hline $0-1$ & $31 \%$ & $33 \%$ & $39 \%$ & $36 \%$ \\
\hline $2-4$ & 42 & 36 & 34 & 32 \\
\hline $5-7$ & 24 & 28 & 24 & 28 \\
\hline $8+$ & 2 & 3 & 3 & 4 \\
\hline
\end{tabular}

TABLE 6.5.B. Number of Energy Conservation Measures Installed by Current Occupant, by Education Level of the Household

\begin{tabular}{|c|c|c|c|c|}
\hline \multirow{2}{*}{$\begin{array}{l}\text { Number of } \\
\text { Energy } \\
\text { Conservation } \\
\text { Measures } \\
\text { Installed } \\
\text { by Current } \\
\text { Occupants }\end{array}$} & \multicolumn{4}{|c|}{$\begin{array}{l}\text { Number of Homeowners (in 1000s) } \\
\text { Heating Fuel Electric }(n=1259) \\
\text { Education Level of the Household }\end{array}$} \\
\hline & $\begin{array}{l}\text { Completed } \\
\text { High School } \\
\text { or Less } \\
(n=46 I) \\
\end{array}$ & $\begin{array}{l}\text { Completed } \\
\text { Irade/Votech } \\
\text { Some College } \\
(n=383) \\
\end{array}$ & $\begin{array}{l}\text { Completed } \\
\text { College } \\
(n=252) \\
\end{array}$ & $\begin{array}{l}\text { At Least } \\
\text { Some Graduate } \\
\text { School }(n=163)\end{array}$ \\
\hline $0-1$ & $35 \%$ & $31 \%$ & $37 \%$ & $44 \%$ \\
\hline $2-4$ & 36 & 38 & 37 & 25 \\
\hline $5-7$ & 27 & 30 & 20 & 24 \\
\hline $8+$ & 2 & 2 & 6 & 7 \\
\hline
\end{tabular}


primary householders had completed high school or less. The second consisted of those who had attended college or who had completed a trade or vocational/ technical school. The third group included only those who had completed college. Finally, the fourth group included those who had attended at least some graduate school. The distribution of these educational groups across the installation activity levels does not suggest any trend or relationship between level of education and the installation of ECMs. Very little difference was found between the data from the entire sample of homeowners and the data from the subset of homeowners using electric heat.

\subsubsection{Total Household Income}

The next demographic variable is that of household income. Household income levels are separated into three groups (see Tables 6.6.A and 6.6.B): incomes under $\$ 16,000$, incomes from $\$ 16,000$ to $\$ 30,000$, and incomes of $\$ 30,000$ or more. A general pattern among the three groups illustrates a positive relationship between income and installation activity; for as income increases, so does the level of past ECM installation. However, this positive relationship is not consistent, particularly at the middle income level which had $39 \%$ in the low installation activity level. This is the largest percentage in the low installation level for any of the income groups. The subset of homeowners using electric heat is even less consistent because $44 \%$ of the $\$ 16,000$ to

TABLE 6.6.A. Number of Energy Conservation Measures Installed by Current Occupants, by Total Household Income

\begin{tabular}{|c|c|c|c|}
\hline \multirow{2}{*}{$\begin{array}{l}\text { Number } \\
\text { of Energy } \\
\text { Conservation } \\
\text { Measures } \\
\text { Installed } \\
\text { by Current } \\
\text { Occupants }\end{array}$} & \multicolumn{3}{|c|}{$\begin{array}{c}\text { Number of Homeowners (in 1000s) } \\
\text { All Heating Fuels ( } n=1977) \\
\text { Tota? Househoid Income }\end{array}$} \\
\hline & $\begin{array}{c}\text { Under } \\
\$ 16,000 \\
(n=451)\end{array}$ & $\begin{array}{l}\$ 16,000 \text { to } \\
\$ 30,000 \\
(n=735)\end{array}$ & $\begin{array}{c}\text { Over } \\
\$ 30,000 \\
(n=791)\end{array}$ \\
\hline $0-1$ & $36 \%$ & $39 \%$ & $28 \%$ \\
\hline $2-4$ & 39 & 33 & 43 \\
\hline $5-7$ & 22 & 27 & 25 \\
\hline $8+$ & 3 & 1 & 5 \\
\hline
\end{tabular}


TABLE 6.6.B. Number of Energy Conservation Measures Installed by Current Occupants, by Total Household Income

\begin{tabular}{|c|c|c|c|}
\hline \multirow{2}{*}{$\begin{array}{l}\text { Number of } \\
\text { Energy } \\
\text { Conservation } \\
\text { Measures } \\
\text { Installed } \\
\text { by Current } \\
\text { Occupants } \\
\end{array}$} & \multicolumn{3}{|c|}{$\begin{array}{l}\text { Number of Homeowners (in 1000s) } \\
\text { Heating Fuel Electric }(n=1161) \\
\text { Total Household Income }\end{array}$} \\
\hline & $\begin{array}{l}\text { Under } \\
\$ 16,000 \\
(n=291) \\
\end{array}$ & $\begin{array}{l}\$ 16,000 \text { to } \\
\$ 30,000 \\
(n=432)\end{array}$ & $\begin{array}{c}\text { Over } \\
\$ 30,000 \\
(n=437) \\
\end{array}$ \\
\hline $0=1$ & $34 \%$ & $44 \%$ & $27 \%$ \\
\hline $2-4$ & 37 & 30 & 44 \\
\hline $5-7$ & 25 & 26 & 24 \\
\hline $8+$ & 3 & 1 & 5 \\
\hline
\end{tabular}

$\$ 30,000$ level falls into the low installation activity group. This is an interesting pattern and may warrant additional or more concentrated analys is in future studies.

6.1.7 Geographic Location of the Survey Residence

The last demographic variable is the geographic location of the survey residence (i.e., survey quadrant). All households were grouped into four geographic areas (see Tables 6.7.A and 6.7.B). The areas include the

TABLE 6.7.A. Number of Energy Conservation Measures Installed by Current Occupants, by Geographic Location (Survey Quadrant)

\begin{tabular}{|c|c|c|c|c|}
\hline $\begin{array}{l}\text { Number of } \\
\text { Energy } \\
\text { Conservation } \\
\text { Measures }\end{array}$ & $\mathrm{Gec}$ & $\begin{array}{l}\text { nber of Ho } \\
\text { It Heating } \\
\text { onic Loact }\end{array}$ & $\begin{array}{l}\text { hers (in } 10 \\
\text { ls (n=2150) } \\
\text { (Survey Ou }\end{array}$ & $n t)$ \\
\hline $\begin{array}{l}\text { Installed } \\
\text { by Current } \\
\text { Occupants }\end{array}$ & $\begin{array}{l}\text { Northwest } \\
\text { A Quad } \\
(n=824) \\
\end{array}$ & $\begin{array}{l}\text { Southwest } \\
\text { B Quad } \\
(n=580) \\
\end{array}$ & $\begin{array}{c}\text { Northeast } \\
\text { C Quad } \\
(n=415) \\
\end{array}$ & $\begin{array}{c}\text { Soutineast } \\
\text { Q Quad } \\
(n=331) \\
\end{array}$ \\
\hline $0-1$ & $38 \%$ & $30 \%$ & $30 \%$ & $38 \%$ \\
\hline $2-4$ & 34 & 39 & 39 & 39 \\
\hline $5-7$ & 24 & 29 & 28 & 21 \\
\hline $8+$ & 4 & 3 & 2 & 2 \\
\hline
\end{tabular}


TABLE 6.7.B. Number of Energy Conservation Measures Installed by Current Occupants, by Geographic Location (Survey Quadrant)

\begin{tabular}{|c|c|c|c|c|}
\hline \multirow{2}{*}{$\begin{array}{l}\text { Number of } \\
\text { Energy } \\
\text { Conservation } \\
\text { Measures } \\
\text { installed } \\
\text { by Current } \\
\text { Dccupants } \\
\end{array}$} & \multicolumn{4}{|c|}{$\begin{array}{l}\text { Number of Homeowners (in 1000s) } \\
\text { Heating Fuel Electric ( } n=1262) \\
\text { Geographic Loaction (Survey Ouadrant) }\end{array}$} \\
\hline & $\begin{array}{l}\text { Northwest } \\
\text { A Quad } \\
(n=500)\end{array}$ & $\begin{array}{l}\text { Southwest } \\
\text { B Quad } \\
(n=323)\end{array}$ & $\begin{array}{l}\text { Northeast } \\
\text { C Quad } \\
(n=250) \\
\end{array}$ & $\begin{array}{l}\text { Southeast } \\
0 \text { Quad } \\
(n=190) \\
\end{array}$ \\
\hline $0-1$ & $37 \%$ & $35 \%$ & $28 \%$ & $42 \%$ \\
\hline $2-4$ & 33 & 34 & 37 & 39 \\
\hline $5-7$ & 25 & 27 & 32 & $1 B$ \\
\hline $8+$ & 5 & 4 & 2 & 1 \\
\hline
\end{tabular}

Northwest, Southwest, Northeast and Southeast. The quadrants are listed below in order from most to least active regarding $E C M$ installation:

- Southwest

- Northeast

- Northwest

- Southeast.

Residents in the Southeast quadrant are less likely to have instalied ECMs than are the residents in all the other quadrants, especially those in the Southwest and Northeast quadrants. Only $23 \%$ of the Southeast residences have reached the medium-high to high activity ievel, while at least $30 \%$ of the residences in the Southwest and Northeast quadrants had achieved the medium-high to high levels of activity.

More pronounced differences occur among the quadrants with regard to installation activity for the subset of homeowners with electric heat (see Table 6.7.B). The quadrants are listed below from most to least active regarding $\mathrm{ECM}$ installation in the electric heat subset:

- Northeast

- Southwest

- Northwest

- Southeast. 
Again, homeowners in the Southeast quadrant are less likely to have installed ECMs than are the residents in all the other quadrants. Only 19\% of the Southeast residences have reached the medium-high to high activity levels, while at least $30 \%$ of the residences in all the other quadrants had achieved the medium-high to high levels of activity.

\subsubsection{A Characteristics of Homeowners in the Low Installation Activity Level} The following are points of interest for the entire sample of homeowners in the low installation activity level (0 to 1 ECMs). These homeowners:

- represent about $60 \%$ of those who have been in their current residences two years or less

- represent $45 \%$ of the 1 -person households and $28 \%$ of the households with 6 or more

- represent $26 \%$ of the crafts-foreman occupation

- represent almost $43 \%$ of the second householders who are in the other employed occupational group

- represent $39 \%$ of the completed college level group and between $31 \%$ and $36 \%$ of the other educational levels

- represent about $36 \%$ of the low income group, $39 \%$ of the middle income group, and $28 \%$ of the high income group

- represent about $38 \%$ of the households in the Southeast and Northwest quadrants and about $30 \%$ of the households in other two quadrants.

\subsubsection{B Characteristics of the Subset of Homeowners with Electric Heat in} the Low Installation Activity Level

The following are points of interest when considering homeowners in the subset using electric heat at the low activity level (0 to 1 ECMs). These homeowners:

- represent about $60 \%$ of those who have been ir their current residences two years or less

- represent $44 \%$ of the 1-person househoids and $34 \%$ of the households with 6 or more 
- represent $37 \%$ of the professional occupational group and between $31 \%$ and $33 \%$ of all other groups

- represent $53 \%$ of the crafts-foreman group and between $21 \%$ and $40 \%$ of all other groups

- represent $44 \%$ of those who had at least some graduate school and between $31 \%$ and $37 \%$ of all other levels

- represent $34 \%$ of the low income group, $44 \%$ of the middle income group, and $27 \%$ of the high income group

- represents $42 \%$ of those in the Southeast quadrant, $37 \%$ in the Northwest quadrant, $35 \%$ in the Southwest, and $28 \%$ in the Northeast quadrant.

6.1.9.A Characteristics of A11 Homeowners in the Medium-Low Installation Activity Leve?

The following are points of interest when considering homeowners in the medium-low installation activity level (2 to 4 ECMs). These homeowners:

- represent over $40 \%$ of those in their homes for 5 or more years

- represent equaliy the househoids having $1,2,3,4,5$, and 6 or more persons

- represent $49 \%$ of the crafts-foreman occupational group

- represent $46 \%$ of the second househoiders in the executiveadministrative-managerial occupational group

- represent $42 \%$ of the households in the completed high school or less ieve?

- represent $39 \%$ of those in the low income group, 33\% in the middle income group, and over $40_{\%}^{\circ}$ in the high income group

- represent just under $40 \%$ of those in the Southwest, Northeast and Southeast quadrants and almost $35 \%$ in the Northwest quadrant. 


\subsubsection{B Characteristics of the Subset of Homeowners with Electric Heat in the Medium-Low Installation Activity Level}

The following are points of interest when considering homeowners of the electric heat subset in the medium-low installation level ( 2 to 4 ECMs). These homeowners:

- represent between $37 \%$ and $39 \%$ of those in their homes for at least 3 years and about 23\% of those in their homes 2 years or less

- represent $41 \%$ of five person households and $29 \%$ of households with six or more (Households with between 1 and 4 occupants are fairiy even.)

- represent only $31 \%$ of the professional occupational group and at least $37 \%$ of all other occupational groups

- represent $62 \%$ of the second householders in the executiveadministrative-managerial occupational group and less than $30 \%$ of the rest of the occupational groups

- represent on $1 y 25 \%$ of those with at least some graduate school and about $37 \%$ of all other educational categories

- represent $37 \%$ of those in the low income group, $30 \%$ in the middle income group, and $44 \%$ in the high income group

- represents $39 \%$ of those in the Southeast, $37 \%$ in the Northeast, $34 \%$ in the Southwest and $33 \%$ in the Northwest.

\subsubsection{A Characteristics of All Homeowners in the Medium-High Installation Activity Leve?}

The following are points of interest when considering homeowners in the medium-high installation activity level (5 to 7 ECMs). These homeowners:

- represent $20 \%$ of those in their homes for 5 or more years

- represent a littie over $20^{\circ}$ of 1 - and 5-person households, and approximately $27 \%$ of $2-, 3-, 4-$, and 6-or more person households 
- represent about $20 \%$ of the executive-administrative-managerial and other employed occupational groups plus about $30 \%$ of the other occupational groups

- represent about $20 \%$ of the second householders in the executiveadministrative-managerial category, about $25 \%$ of the professionals, and about $30 \%$ of all the other categories

- represent between $24 \%$ and $28 \%$ of all the educational levels

- represent between $22 \%$ and $27 \%$ of all the income levels

- represent about $28 \%$ of both the Southwest and Northeast quadrants, $24 \%$ of the Northwest quadrant, and only about $20 \%$ of the Southeast quadrant.

6.1.10.B Characteristics of the Subset of Homeowners with Electric Heat in the Medium-High Installation Activity Level

The following are points of interest when considering the subset of homeowners using electric heat in the medium-high activity level (5 to $7 \mathrm{ECMs}$ ). These homeowners:

- represent $30 \%$ of those in their homes for 5 or more years

- represent between $21 \%$ and $31 \%$ for all categories

- represent about $29 \%$ of the professional and clerical-sales-technician occupational groups and about $21 \%$ of the other occupational groups

- represent only $11 \%$ of the second-householders in the executiveadministrative-managerial occupational category and at least $30 \%$ of all the other categories

- represent between $20 \%$ and $30 \%$ of all the educational levels

- represent approximately a quarter of each income level

- represent atout $26 \%$ of the Northwest and Southwest quadrants, $32 \%$ of the Northeast quadrant, and oniy $18 \%$ of the Southeast quadrant. 


\subsubsection{A Characteristics of All Homeowners in the High Installation Activity Level}

The following are points of interest when considering homeowners in the high installation activity level (8+ECMs). These homeowners:

- represent about $3 \%$ in the categories of under 1 year and over 5 years in current residence

- represent $0 \%$ in 1- and 4-person households but do represent $7 \%$ of the households with 6 or more occupants

- represent $4 \%$ of the professional-occupational group which is the largest proportion in any of the categories

- represent $5 \%$ of the second householders in the crafts-foreman occupation and do not represent the clerical-sales-technical occupational group

- represent between $2 \%$ and $4 \%$ of all the education levels, $2 \%$ of the lowest level, and $4 \%$ of the highest level

- represent $3 \%$ of the low income, $1 \%$ of the middle income, and $5 \%$ of the high incone levels

- represent $4 \%$ of the households in the Northwest quadrant and between $2 \%$ and $3 \%$ of the other quadrants.

6.1.11.8 Characteristics of the Subset of Homeowners with Electric Heat in the High Installation Activity Level

The following are points of interest when considering the subset of homeowners using electricity who are in the high activity level (8+ECMs). These homeowners:

- represent the categories of under 1 year and over 5 years in current residence

- represent no 1 and 4 person households but do represent $10 \%$ of the households with 6 or more occupants

- represent none of the crafts-foreman category, 1\% of clerical-salestechnician category, and $4 \%$ of all other occupational categories 
- represent $5 \%$ of the second householders in the executiveadministrative-managerial category and are not represented in the clerical-sales-technical category

- represent between $6 \%$ and $7 \%$ of those who have completed college and only $2 \%$ who have not finished or have never attended college

- represent $3 \%$ of the low income, $1 \%$ of the middle income, and $5 \%$ of the high income leveis

- represent $5 \%$ of the Northwest quadrant, $4 \%$ of the Southwest, $2 \%$ of the Northeast, and $1 \%$ of the Southeast quadrants.

6.2 DEMOGRAPHIC INFLUENCES ON LIKELIHOOD OF FUTURE INSTALLATION OF ENERGY CONSERVATION MEASURES

By using the same demographic variables that are related to conservation behavior, it may be possible to determine conservation intentions. One demographically defined group may be more or less likely than another to invest in ECMs. If one group proves more likely, BPA can target it for future programs. 6.2.1 Length of Time at Current Residence

In Table 6.8.A, the data points out that for all homeowners the length of time they occupy a residence has an effect on the number of ECMs which they are

TABLE 6.8.A. Number of Energy Conservation Measures Homeowners Are Somewhat or Very Likely to Install in the Next Two to Three Years, by Length of Time at Current Residence

\begin{tabular}{|c|c|c|c|c|}
\hline \multirow{2}{*}{$\begin{array}{l}\text { Number of } \\
\text { Energy } \\
\text { Conservation } \\
\text { Measures } \\
\text { Somewhat or } \\
\text { Very Likely } \\
\text { to Install } \\
\end{array}$} & \multicolumn{4}{|c|}{$\begin{array}{l}\text { Number of Homeowners (in 1000s) } \\
\text { A1 Heating Fueis ( } n=2148 \text { ) } \\
\text { Length of Time at Current Residence }\end{array}$} \\
\hline & $\begin{array}{l}\text { Under } \\
1 \text { Year } \\
(n=268)\end{array}$ & $\begin{array}{c}1-2 \\
\text { Years } \\
(n=153) \\
\end{array}$ & $\begin{array}{c}3-4 \\
\text { Years } \\
(n=236) \\
\end{array}$ & $\begin{array}{l}\text { Over } \\
5 \text { Years } \\
(n=1492) \\
\end{array}$ \\
\hline 0 & $18 \%$ & $24 \%$ & $32 \%$ & $43 \%$ \\
\hline $1-2$ & 43 & 44 & 45 & 38 \\
\hline $3+$ & 39 & 31 & 23 & 19 \\
\hline
\end{tabular}


somewhat or very likely to install. In general, as length of stay in a residence increases, likelihood of installation decreases. For example, for those living in their residences less than a year, fewer than $20 \%$ said they were not likely to invest in any ECMs, while over $40 \%$ of those living in their residences for 5 years or more said they were not likely to invest in any ECMS. Furthermore, nearly 39\% of the less-than-a-year group responded that they were somewhat or very likely to install three or more ECMs, while only $19 \%$ of those in the five years or more group gave the same response. A similar pattern can be seen in the subset of homeowners with electric heat (see Table 6.8.B).

\subsubsection{Number of Occupants in Residence}

The next variable is the total number of occupants in a residence. Looking at Table 6.9.A for all homeowners, a definite pattern indicates that likelihood of installation increases as the number of occupants in a residence increases. For instance, $57 \%$ of the 1-person households said they were not likely to invest in any ECMs, while approximately $21 \%$ of the households with at least 4 occupants responded this way. Further fllustrating the pattern are the percentages in the highest likelihood level. Only $15 \%$ of the 1-person households fall into this category, compared with $28 \%$ of the 6-or-more person households. The subset of homeowners with electric heat demonstrates a similar pattern of response (see Table 6.9.B), but the relationship between likelihood of installations and size of household is not as clear, especially at the highest level of likelihood.

TABLE 6.8.B. Number of Energy Conservation Measures Homeowners Are Somewhat or Very Likely to Insta?l in the Next Two to Three Years, by Length of Time at Current Residence

Number of

Energy

Conservation

Measures

Somewhat or

Very Likely

to Install

0

$1-2$

$3+$
Number of Homeowners (in 1000s)

Heating Fuel Electric $(n=1261)$

Length of Time at Current Residence

\begin{tabular}{|c|c|c|c|}
\hline Under & $1-2$ & $3-4$ & Over \\
\hline $\begin{array}{r}1 \text { Year } \\
(n=186)\end{array}$ & $\begin{array}{l}\text { Years } \\
(n=89)\end{array}$ & $\begin{array}{c}\text { Years } \\
(n=144)\end{array}$ & $\begin{array}{l}5 \text { Years } \\
(n=842)\end{array}$ \\
\hline $24 \%$ & $37 \%$ & $37 \%$ & $41 \%$ \\
\hline 41 & 48 & 38 & 42 \\
\hline 36 & 15 & 25 & 17 \\
\hline
\end{tabular}


TABLE 6.9.A. Number of Energy Conservation Measures Homeowners Are Somewhat or Very Likely to Install in the Next Two or Three Years, by Number of Occupants in the Household

\begin{tabular}{|c|c|c|c|c|c|c|}
\hline \multirow{2}{*}{$\begin{array}{c}\text { Number of } \\
\text { Energy } \\
\text { Conservation } \\
\text { Measures } \\
\text { Somewhat or } \\
\text { Very Likely } \\
\text { to Instali }\end{array}$} & \multicolumn{6}{|c|}{$\begin{array}{l}\text { Number of Homeowners (in 1000s) } \\
\text { All Heating Fuels }(n=2150) \\
\text { Number of Occupants Including Homeowner }\end{array}$} \\
\hline & $(n=307)$ & $(n=746)$ & $(n=383)$ & $\begin{array}{c}4 \\
(n=404) \\
\end{array}$ & $(n=181)$ & $\begin{array}{c}6 \text { or more } \\
(n=128)\end{array}$ \\
\hline 0 & $57 \%$ & $49 \%$ & $29 \%$ & $21 \%$ & $21 \%$ & $22 \%$ \\
\hline $1-2$ & 28 & 34 & 50 & 40 & 54 & 50 \\
\hline $3+$ & 15 & 17 & 21 & 39 & 25 & 28 \\
\hline
\end{tabular}

TABLE 6.9.8. Number of Energy Conservation Measures Homeowners Are Somewhat or Very Likely to Install in the Next Two or Three Years, by Number of Occupants in the Household

\begin{tabular}{|c|c|c|c|c|c|c|}
\hline $\begin{array}{l}\text { Conservation } \\
\text { Measures } \\
\text { Somewhat or }\end{array}$ & & $\begin{array}{r}\text { Numb } \\
\text { Heat } \\
\text { Vumber } 0\end{array}$ & $\begin{array}{l}\text { of Hom } \\
\text { g Fuel } \\
\text { Occuoan }\end{array}$ & $\begin{array}{l}\text { wners } \\
\text { ectric } \\
\text { includ }\end{array}$ & $\begin{array}{l}10005) \\
=1262) \\
g \text { Homeor }\end{array}$ & ter \\
\hline $\begin{array}{l}\text { Very Likely } \\
\text { to lnstal? }\end{array}$ & $\begin{array}{c}1 \\
(n=185)\end{array}$ & $\begin{array}{c}2 \\
(n=430)\end{array}$ & $(n=232)$ & $(n=210)$ & $\begin{array}{c}5 \\
(n=118)\end{array}$ & $\begin{array}{l}6 \text { or more } \\
(n=88)\end{array}$ \\
\hline 0 & $56 \%$ & $50 \%$ & $28 \%$ & $23 \%$ & $22 \%$ & $22 \%$ \\
\hline $1-2$ & 25 & 35 & 53 & 43 & 60 & 54 \\
\hline $3+$ & 20 & 15 & 19 & 34 & 18 & 24 \\
\hline
\end{tabular}

\subsubsection{Educational Level of the Household}

Relative to likelihood of instaling ECMs, the third demographic variable is level of education in the household, defined as the highest level of formal education achieved by either of the primary householders. Looking at Tabie 6.10.A for all homeowners, a pattern emerges suggesting that education has a strong influence on likelihood of future investment. For example, 47\% of those who completed high school or less said they were neither somewhat nor very likely to install even a single ECM. Only 19\% of those having attended some graduate school gave such a response. Among those likely to install three or more ECMs, the pattern is not as evident but stili exists. Only $16^{\circ}$ of 
TABLE 6.10.A. Number of Energy Conservation Measures Homeowners Are Somewhat or Very Likely to Install in the Next Two to Three Years, by Level of Education

\begin{tabular}{|c|c|c|c|c|}
\hline \multirow{2}{*}{$\begin{array}{l}\text { Number of } \\
\text { Energy } \\
\text { Conservation } \\
\text { Measures } \\
\text { Somewhat or } \\
\text { Very Likely } \\
\text { to Install } \\
\end{array}$} & \multicolumn{4}{|c|}{$\begin{array}{l}\text { Number of Homeowners (in 1000s) } \\
\text { All Heating Fuels }(n=2140) \\
\text { Education Level of the Household (a) }\end{array}$} \\
\hline & $\begin{array}{l}\text { Completed } \\
\text { High School } \\
\text { or Less } \\
(n=763) \\
\end{array}$ & $\begin{array}{l}\text { Completed } \\
\text { Trade/Votech } \\
\text { Some College } \\
\quad(n=661) \\
\end{array}$ & $\begin{array}{l}\text { Completed } \\
\text { College } \\
(n=426) \\
\end{array}$ & $\begin{array}{l}\text { At Least } \\
\text { Some Graduate } \\
\text { School }(n=290) \\
\end{array}$ \\
\hline 0 & $47 \%$ & $35^{\circ}$ & $36 \%$ & $19 \%$ \\
\hline $1-2$ & 36 & 38 & 41 & 52 \\
\hline $3+$ & 16 & 28 & 23 & 29 \\
\hline
\end{tabular}

(a) Level of education attained by the most educated person in the household.

those in the lowest educational level were likely to install three or more ECMs compared with $29 \%$ of those in the highest educational level. The distribution for the subset of homeowners using electric heat is similar (see Table 6.10.B).

TABLE 6.10.B. Number of Energy Conservation Measures Homeowners Are Somewhat or Very Likely to Install in the Next Two to Three Years, by Level of Education

\begin{tabular}{|c|c|c|c|c|}
\hline \multirow{2}{*}{$\begin{array}{l}\text { Number of } \\
\text { Energy } \\
\text { Conservation } \\
\text { Measures } \\
\text { Somewhat or } \\
\text { Very Likely } \\
\text { to Install } \\
\end{array}$} & \multicolumn{4}{|c|}{$\begin{array}{r}\text { Number of Homeowners (in 1000s) } \\
\text { Heating Fuel Electric }(n=1259) \\
\text { Education Level of the Household }(a)\end{array}$} \\
\hline & $\begin{array}{l}\text { Completed } \\
\text { Hi gh School } \\
\text { or Less } \\
(n=461) \\
\end{array}$ & $\begin{array}{l}\text { Completed } \\
\text { Trade/Votech } \\
\text { Some College } \\
\quad(n=383) \\
\end{array}$ & $\begin{array}{l}\text { Completed } \\
\text { College } \\
(n=252) \\
\end{array}$ & $\begin{array}{l}\text { At Least } \\
\text { Some Graduate } \\
\text { Schoot }(n=163) \\
\end{array}$ \\
\hline 0 & $50 \%$ & $36 \%$ & $32 \%$ & $20 \%$ \\
\hline $1-2$ & 36 & 39 & 45 & 60 \\
\hline $3+$ & 15 & 26 & 23 & 20 \\
\hline
\end{tabular}




\subsubsection{Total Household Income}

The next demographic variable considered in relation to likelihood of installing ECMs is that of household income. Househoids were categorized into three types: those with less than $\$ 16,000$ income, those with between $\$ 16,000$ and $\$ 30,000$, and those with more than $\$ 30,000$. The relationship between income and likelihood is expected to be positive and it generally is. In other words, as income increases so does the rikelihood of investment. Looking at the distribution of responses from all income levels (see Table 6.11.A), 55\% of those at the lowest income level indicated that they were not likely tc invest in any ECMs. Only $33 \%$ of those at the $\$ 30,000$ or more level fell into that category. Only 13\% of the low-income group are likely to install three or more ECMS, while 25\% of the high-income group are found in the high likelihood category. However, the data in Table 6.11.A indicate that the income effect is not linear. Thus, those with the highest level of income are not necessarity the ones most likely to invest. In fact, those in the medium-income level are those most likely to invest in ECMs. This anomaly may occur because those at the high-income level have either purchased all available ECMs or are not as concerned about the costs of energy and are not compelled to invest further in ECMs. The subset of homeowners with electric heat have a similar distribution which can be seen in Table 6.11.B.

TABLE 6.11.A. Number of Energy Conservation Measures Homeowners Are Somewhat or Very Likely to Install in the Next Two to Three Years, by Total Household Income

\begin{tabular}{|c|c|c|c|}
\hline \multirow{2}{*}{$\begin{array}{l}\text { Number of } \\
\text { Energy } \\
\text { Conservation } \\
\text { Measures } \\
\text { Somewhat or } \\
\text { Very Likely } \\
\text { to Install }\end{array}$} & \multicolumn{3}{|c|}{$\begin{array}{c}\text { Number of Homeowners (in 1000s) } \\
\text { Ail Heating Fuels ( } n=1977) \\
\text { Total Household Income }\end{array}$} \\
\hline & $\begin{array}{l}\text { Under } \\
\$ 16,000 \\
(n=451)\end{array}$ & $\begin{array}{l}\$ 16,000 \text { to } \\
\$ 30,000 \\
(n=735)\end{array}$ & $\begin{array}{c}\text { Over } \\
\$ 30,000 \\
(n=791)\end{array}$ \\
\hline 0 & $55 \%$ & $27 \%$ & $33^{\circ}$ \\
\hline $1-2$ & 32 & 44 & 42 \\
\hline $3+$ & 13 & 29 & 25 \\
\hline
\end{tabular}


TABLE 6.11.B. Number of Energy Conservation Measures Homeowners Are Somewhat or Very Likely to Install in the Next Two to Three Years, by Total Household Income

\begin{tabular}{|c|c|c|c|}
\hline \multirow{2}{*}{$\begin{array}{l}\text { Number of } \\
\text { Energy } \\
\text { Conservation } \\
\text { Measures } \\
\text { Somewhat or } \\
\text { Very Likely } \\
\text { to Insta? }\end{array}$} & \multicolumn{3}{|c|}{$\begin{array}{l}\text { Number of Homeowners (in 1000s) } \\
\text { Heating Fuel Electric }(n=1161) \\
\text { Total Household Income }\end{array}$} \\
\hline & $\begin{array}{l}\text { Under } \\
\$ 16,000 \\
(n=291) \\
\end{array}$ & $\begin{array}{l}\$ 16,000 \text { to } \\
\$ 30,000 \\
(n=432) \\
\end{array}$ & $\begin{array}{l}\text { Over } \\
\$ 30,000 \\
(n=437) \\
\end{array}$ \\
\hline 0 & $58 \%$ & $28 \%$ & $30 \%$ \\
\hline $1-2$ & 30 & 42 & 50 \\
\hline $3+$ & 12 & 29 & 19 \\
\hline
\end{tabular}

\subsubsection{Geographic Location of the Survey Residence}

The last demographic variable of interest is the geographic location (i.e., survey quadrant) of the respondent. The numbers for homeowners using all fuels (see Table 6.12.A) indicate that those in the Northwest quadrant are the most likely to invest in ECMs, followed secondly by those in the Southeast. Homeowners in the Southwest and Northeast quadrants have similar distributions and are least likely to install ECMs. As likelihood of investment increases, representation of both the Southwest and Northeast populations decreases linearly, in contrast with the bell-shaped distribution curve of the Northwest and Southeast. This is probably a function of past behavior regarding

TABLE 6.12.A. Number of Energy Conservation Measures Homeowners Are Somewhat or Very Likely to Install in the Next Two to Three Years, by Geographic Location (Survey Quadrant)

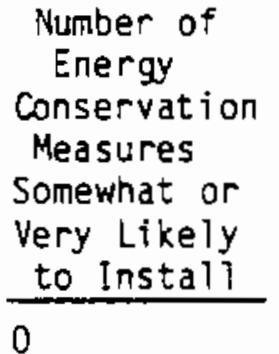

$1-2$

$3+$
Number of Homeowners (in 1000s)

All Heating Fuels $(n=2150)$ Geographic Location (Survey Ouadrant)

\begin{tabular}{|c|c|c|c|}
\hline $\begin{array}{l}\text { Northwest } \\
\text { A Ouad } \\
(n=824)\end{array}$ & $\begin{array}{c}\text { Southwest } \\
\text { B Quad } \\
(n=580)\end{array}$ & $\begin{array}{l}\text { Northeast } \\
\text { C Ouad } \\
(n=415) \\
\end{array}$ & $\begin{array}{l}\text { Southeast } \\
\text { D Quad } \\
(n=331) \\
\end{array}$ \\
\hline $33 \%$ & $42 \%$ & $41 \%$ & $36 \%$ \\
\hline 42 & 37 & 38 & 43 \\
\hline 25 & 22 & 21 & 21 \\
\hline
\end{tabular}


installing ECHs which was previously discussed in Section 6.1.7. Referring back to Table 6.7.A, residents in the Southwest and Northeast quadrants had the highest level of past installation activity. Therefore, the logical assumption is that high installation activity in the past reduces the likelihood of future installations.

The data for the subset of homeowners with electric heat (see Table 6.12.B) indicate that those in the Southeast quadrant are the most 1 ikely to invest in ECMs, followed secondiy by those in the Northwest, thus reversing the previous rankings from the total sample. The homeowners in the Southwest and Northeast are the least likely to install ECMs. Referring back to Table 6.7.B, residents in the Southwest and Northeast quadrants had the highest level of past installation activity. Again, it is logical to assume that high installation activity in the past reduces the likelihood of future installations.

\subsubsection{A Characteristics of All Homeowners Not Likely to Install Energy Conservation Measures}

The following are points of interest regarding homeowners who are not likely to install any ECMs. These honeowners:

- represent $18 \%$ of occupants in their homes iess than a year and $43 \%$ of occupants in their homes for 5 or more years

TABLE 6.12.B. Number of Energy Conservation Measures Homeowners Are Somewhat or Very Likeiy to Install in the Next Two to Three Years, by Geographic Location (Survey Quadrant)

\begin{tabular}{|c|c|c|c|c|}
\hline $\begin{array}{l}\text { Number of } \\
\text { Energy } \\
\text { Conservation } \\
\text { Measures }\end{array}$ & \multicolumn{4}{|c|}{$\begin{array}{l}\text { Number of Homeowners (in 1000s) } \\
\text { Heating Fue? Electric ( } n=1262) \\
\text { Geographic Location (Survey Ouadrant) }\end{array}$} \\
\hline $\begin{array}{l}\text { Somewhat or } \\
\text { Very Likely } \\
\text { to Install } \\
\end{array}$ & $\begin{array}{c}\text { Northwest } \\
\text { A Quad } \\
(n=500)\end{array}$ & $\begin{array}{c}\text { Southwest } \\
\text { B Quad } \\
(n=323) \\
\end{array}$ & $\begin{array}{l}\text { Northeast } \\
\text { C Quad } \\
(n=250)\end{array}$ & $\begin{array}{l}\text { Southeast } \\
D \text { Quad } \\
(n=190)\end{array}$ \\
\hline 0 & $35^{\circ}$ & $45^{\circ}$ & $40 \%$ & $31 \%$ \\
\hline $1-2$ & 42 & 39 & 41 & 48 \\
\hline $3+$ & 23 & 17 & 19 & 21 \\
\hline
\end{tabular}


- represent $57 \%$ of the 1-person households and $22 \%$ of the households with 6 or more occupants

- represent $47 \%$ of the householders with high school or iess and $19 \%$ of those having some graduate school

- represent $55 \%$ of the low income group, $27 \%$ of the middle income group, and $33 \%$ of the high income group

- represent about $41 \%$ of those in the Southwest and Northeast quadrants and between $33 \%$ and $36 \%$ of those in the Northwest and Southeast quadrants.

6.2.6.B Characteristics of the Subset of Homeowners with Electric Heat who Are Not Likely to Install Energy Conservation Measures

The following are points of interest regarding the subset of homeowners using electric heat. These homeowners:

- represent $24 \%$ of those in their homes less than a year and $41 \%$ of those in their homes for 5 or more years

- represent $56 \%$ of the 1-person households and $22 \%$ of the households with at least 5 people

- represent $50 \%$ of those completing high school or less and $20 \%$ of those having some graduate school

- represent $58 \%$ of the low income group, $28 \%$ of the middle income group, and $30 \%$ of the high income group

- represent $45 \%$ of the Southwest quadrant, $40 \%$ of the Northeast, $35_{\%}^{\circ}$ of the Northwest, and $33 \%$ of the southeast quadrant.

\subsubsection{A Characteristics of A11 Homeowners Likely to Install One or Two Energy Conservation Measures}

The following are points of interest regarding homeowners who are likely to install one or two ECMs. These homeowners:

- represent between $38 \%$ and $43 \%$ of all the length-of-residence categories 
- represent $28 \%$ of the 1-person households and $50 \%$ of the 6 -or-more person households

- represent $36 \%$ with a high school degree or less and $52 \%$ with at least some graduate schooi

- represent $32 \%$ of the low income, $44 \%$ of the middle income, and $42 \%$ of the high income groups

- represent $37 \%$ of the Southwest and Northeast and $43 \%$ of the Northwest and Southeast quadrants.

6.2.7. B Characteristics of the Subset of Homeowners with Electric Heat who Are Likely to Install 1 to 2 Energy Conservation Measures

The following are points of interest regarding homeowners in the electric heat subset likely to install 1 to 2 ECMs. These homeowners:

- represent between $38 \%$ and $48 \%$ of all categories having to do with iength of residence

- represent $25 \%$ of 1-person households and $54 \%$ of households with six or more

- represent $36 \%$ of those with high school or iess and $60 \%$ of those with at least some graduate schoo?

- represent $30 \%$ of the low income, $42 \%$ of the middle income, and $50 \%$ of the high income ievels

- represent $48 \%$ of the Southeast quadrant and roughly $40 \%$ of the others.

6.2.8. A Characteristic of All Homeowners Likely to Instali Three or More Energy Conservation Measures

The following are points of interest regarding homeowners likely to install three or more ECMs. These homeowners:

- represent 39\% of those who have been in their homes less than a year, and $19 \%$ of those in their homes 5 or more years 
- represent $15 \%$ of the one-person households and $28 \%$ of the households with six or more.

- represent $16 \%$ of those with high school or less and $29 \%$ of those with at least some graduate school

- represent $13 \%$ of the low income, $29 \%$ of the middle income, and $25 \%$ of the high income groups

- represent $25 \%$ of the Northwest quadrant, $21 \%$ of both the Southwest and Northeast quadrants, and $20 \%$ of the Southeast quadrants.

6.2.8.B Characteristics of the Subset of Homeowners with Electric Heat Who Are Likely to Instal1 Three or More Energy Conservation Measures

The following are points of interest for the subset of electric heat homeowners who are likely to install 3 or more ECMs. These homeowners:

- represent $36 \%$ of those in their homes less than a year and $17 \%$ of those in their homes for 5 or more years

- represent $34 \%$ of 4 person households and no more than $24 \%$ of any other size househoid

- represent $26 \%$ of those who completed Trade/Votech or had some college and no more than $23 \%$ of any other occupational category

- represent $12 \%$ of low income, $29 \%$ of middle income, and $19 \%$ of high income groups

- represent $23 \%$ of the Northwest quadrant, about $20 \%$ of both the Northeast and the Southeast quadrants, and $17 \%$ of the Southwest quadrant.

\subsection{SUMMARY OF FINDINGS IN CHAPTER 6}

In Section 1 of Chapter 6, past conservation behavior related to installing ECMs was studied to determine if certain demographic factors influenced the homeowners. The resulting general trends are as follows:

- As length of time in a home increases, so does the number of ECMs instalied. One exception is that, as indicated by the data, if $8+$ 
ECMs are not installed within one year of initially occupying the home, it is not likely that this high level of $8+$ ECMs will be reached later.

- As number of people in the household increases, so does the number of ECMs installed. The exception is that 4- and 5-person households are not as likely to have instalied 8+ ECMs as are the 2-and 3-person households.

- Occupational groups exhibited a large variability within each group regarding ECM installation. However, no single group was highly active or inactive.

- Second-householder occupation groups exhibited a large variability within each group regarding ECM installation, and no single-group was highly active nor inactive.

- As level of education increases, so does the number of ECMs installed.

- As iever of househoid income increases, so does the number of ECMs installed.

- The Southwest quadrant has been most active followed by the Northeast, the Northwest, and last, the Southeast.

In the second section of Chapter 6, likelinood of future ECM installation was studied to determine if certain demographic factors influenced the homeowners. The same demographic variables from Section 1 were used, except for the occupational variables. The resulting general trends are as follows:

- As length of time in a home increases, the likelihood of future ECM installation decreases.

- As number of people in the household increases, so does the likelihood of future ECM installation.

- As level of education increases, so does the likelihood of future ECM installation. 
- As level of income increases, so does the likelihood of future ECM installation.

- The Northwest and Southeast quadrants are the most likely to install ECMs in the future.

The hypothesis tested in this chapter states that consumer behavior and intentions toward installation of energy conservation measures will not vary by demographically defined groups. The results in Section 5.3 indicate certain demographic variables do in fact have an effect both on past behavior and future plans to install ECMs. Of the seven demographic variables used to test the hypothesis with regard to past behavior, five had some degree of influence on the number of energy conservation measures installed.

In the section looking at likelihood of installing conservation measures, it is apparent from the data that demographic variabies have a stronger effect on homeowners' intentions than on their actual behavior, and should be used by BPA in conjunction with self reported behavior, to target future programs. For exampie, results indicate that: it is important to promote installing as many ECMs, in the first year of occupation in a new home, as possible; larger households are more likely to install ECMs, both education and income have a positive effect on likelihood of ECM installation; and finally and maybe most importantiy homeowners in the Northwest and Southeast had been least active in the past but report greater likelihood of ECM installation in the future. 


\subsection{SEGMENTATION BY FAMILY LIFE CYCLE AND VALUE, ATTITUDE AND LIFESTYLE STATEMENTS}

One way to classify households in particular market segments is by family life cycle characteristics. Classifying families into life cycle segments is useful to researchers concerned with energy consumption behavior of families and to marketers concerned with segmenting their markets. Family life cycle segments are considered a progression of stages through which families may pass over a course of time. This type of a segmentation scheme was originally developed during the 1950's and 1960's with the nuclear family as the model. However, today the standard family 3 ife cycle segments may no longer be appropriate considering the number of single parent families, the couples who choose not to have children and the re-emergence of the extended family. For these reasons, recently developed life cycle segments should more appropriately address current family demographics. Households are segmented according to the number of household members, their ages, whether there are children in the family, and if so, the ages of the children. By placing families into groups based on a combination of such demographic variables, a more in-depth picture of the family is obtained than would be possible using any single variable. One objective of this chapter is to test the hypothesis that consumer behavior and intentions toward conservation investment will not vary by the family life cycle in which a household currentiy finds itself.

Another way to classify respondents is to observe their responses to a series of value, attitude and lifestyle (VAL) statements. Through a multivariate statistical procedure called factor analysis, a series of variables, (i.e., VALs), can be clustered into a few variables or factors to reflect the underiying attributes of the respondents. Each respondent receives a score for each factor and these scores are used to compare respondents in regards to variables such as age, sex, preferences for reducing energy use in the home, etc. A secand objective of this chapter is therefore, to test the hypothesis that consumer behavior and intentions toward conservation investment will not vary by the responses to the VAL statements. 


\subsection{FAMILY LIFE CYCLE SEGMENTS--METHOOOLOGY}

In order to create family life cycle segments, several demographic variables are usually used to classify households. These variables can include marital status, age of family members, size of the family, and the work status of the head of household. Since the survey did not ask about mirital status or whether head of household was retired, only the ages of the family members and the size of the family was used to create the life cycle segments.

Families in each life cycle segment can choose different ways to allocate their incomes. For example, households with children have quite different expenditures than those with no children. Likewise, young persons of 34 years or iess will more likely spend money on setting up their first household. On the other hand, older persons of 65 years and older will usually have established a household and may more likely spend money on pleasurable and timeconsuming activities such as trips and vacations.

Seven life cycle segments were chosen for the current analyses and are defined as follows:

- Young Adults-Childless. All adults in the household are 18 to 34 years old, and there are no children living at home.

- Middie-Aged Aduits-Childless. All aduits in the household are 35 to 64 years old, and there are no children living at home.

- Mixed Generation Adults. There is at least one aduit in the household 18 to 34 years old and one adult 35 to 64 years old. There are no children living at home.

- Retired. ATl aduits in the household are 64 years old or older, and there are no children living at home.

- Early Parenthood. All adults in the household are 18 to 64 years old, and the youngest child living at home is 5 years old or younger.

- Late Parenthood. All adults in the household are 18 to 64 years old, and the youngest child living at home is 6 years old or older.

- Extended Family. There is at least one adult in the househoid 65 years old or older and one child 17 years old or younger. 
These seven segments account for approximately $92 \%$ of the homeowners in the sample.

\subsection{DEMOGRAPHIC BREAKDOWN OF FAMILY LIFE CYCLE SEGMENTS}

Before analyzing whether consumer behavior and intentions toward conservation vary by $l i f e$ cycle segments, it is important to determine the demographic differences between life cycle segments. For exampie, these differences may indicate a relationship between total household income and life cycle segments (see Tables 7.1.A and 7.1.B). The life cycle segments that most frequently had a total household income over $\$ 30,000$ were Mixed Generation Adults, Late Parenthood, and Young Adults-Childless. Conversely, the life cycle segments that most frequentiy had total household incomes of less than $\$ 16,000$ were Retired and Extended family.

0istinct demographic differences occur between life cycle segments and length of time the household has lived at the current residence (see Tables 7.2.A and 7.2.B). Over $70 \%$ of the households within each segment had

TABLE 7.1.A. Total Household Income, by Life Cycle Segments

\begin{tabular}{|c|c|c|c|}
\hline Number of Homeowners (in 1000s) & & Household & \\
\hline $\begin{array}{l}\text { Al1 heating Fuels ( } n=1848) \\
\text { Life Cycle Segment }\end{array}$ & $\begin{array}{l}\text { Less than } \\
\$ 16,000\end{array}$ & $\begin{array}{l}\$ 16,000 \text { to } \\
\$ 30,000\end{array}$ & $\begin{array}{l}\text { More than } \\
\$ 30,000\end{array}$ \\
\hline Young adults childless $(n=145)$ & $8 \%$ & $50 \%$ & $43 \%$ \\
\hline $\begin{array}{l}\text { Middie aged aduits } \\
\text { childless }(n=497)\end{array}$ & 21 & 37 & 41 \\
\hline $\begin{array}{l}\text { Mixed generation adults } \\
\text { childiess }(n=156)\end{array}$ & 22 & 23 & 55 \\
\hline Retired childless $(n=260)$ & 56 & 27 & 17 \\
\hline $\begin{array}{l}\text { Early parenthood } \\
\text { youngest child \&5 }(n=356)\end{array}$ & 15 & 47 & 38 \\
\hline $\begin{array}{l}\text { Late parenthood } \\
\text { youngest child }>6 \quad(n=406)\end{array}$ & 14 & 36 & 50 \\
\hline Extended family $(n=28)$ & 30 & 47 & 23 \\
\hline
\end{tabular}


TABLE 7.1.B. Total Household Income, by Life Cycle Segments

\begin{tabular}{|c|c|c|c|}
\hline \multirow{2}{*}{$\begin{array}{c}\text { Number of Homeowners (in 1000s) } \\
\text { Heat ing Fuel Electric }(n=1091) \\
\text { Life Cycle Segment }\end{array}$} & \multicolumn{3}{|c|}{ Total Household Income } \\
\hline & $\begin{array}{l}\text { Less than } \\
\$ 16,000 \\
\end{array}$ & $\begin{array}{l}\$ 16,000 \text { to } \\
\$ 30,000\end{array}$ & $\begin{array}{l}\text { More than } \\
\$ 30,000 \\
\end{array}$ \\
\hline Young adults childless $(n=84)$ & $9 \%$ & $44 \%$ & $47 \%$ \\
\hline $\begin{array}{l}\text { Middle aged adults, } \\
\text { childless }(n=253)\end{array}$ & 26 & 38 & 35 \\
\hline $\begin{array}{l}\text { Mixed generation adults } \\
\text { childless }(n=69)\end{array}$ & 23 & 20 & 58 \\
\hline Retired childless ( $n=176)$ & 56 & 31 & 13 \\
\hline $\begin{array}{l}\text { Early parenthood } \\
\text { youngest child }<5 \quad(n=227)\end{array}$ & 17 & 42 & 41 \\
\hline $\begin{array}{l}\text { Late parenthood } \\
\text { youngest child }>6 \quad(n=260)\end{array}$ & 15 & 37 & 48 \\
\hline Extended family $(n=22)$ & 14 & 58 & 28 \\
\hline
\end{tabular}

TABLE 7.2.A. Length of Time Respondents Have Been at Their Current Residence, by Life Cycle Segments

\begin{tabular}{|c|c|c|c|c|}
\hline \multirow[b]{2}{*}{$\begin{array}{c}\text { Number of Homeowners (in 1000s) } \\
\text { A11 Heating Fuels }(n=1986) \\
\text { Life Cycle Segment }\end{array}$} & \multicolumn{4}{|c|}{ Length of Time At Current Residence } \\
\hline & $\begin{array}{l}\text { Less } \\
\text { than } \\
\text { One Year } \\
\end{array}$ & $\begin{array}{l}1-2 \\
\text { Years } \\
\end{array}$ & $\begin{array}{c}3-4 \\
\text { Years } \\
\end{array}$ & $\begin{array}{r}5 \text { or } \\
\text { more } \\
\text { Years } \\
\end{array}$ \\
\hline Young adults childless $(n=154)$ & $41 \%$ & $18 \%$ & $14 \%$ & $27 \%$ \\
\hline $\begin{array}{l}\text { Middle aged adults } \\
\text { childiess }(n=538)\end{array}$ & 8 & 6 & 10 & 76 \\
\hline $\begin{array}{l}\text { Mixed generation adults } \\
\text { childless }(n=163)\end{array}$ & 10 & 10 & 2 & 78 \\
\hline Retired childless $(n=283$ ) & 2 & 4 & 6 & 88 \\
\hline $\begin{array}{l}\text { Early parenthood } \\
\text { youngest child }<5 \quad(n=365)\end{array}$ & 24 & 9 & 19 & 48 \\
\hline $\begin{array}{l}\text { Late parenthood } \\
\text { youngest child }>6 \quad(n=453)\end{array}$ & 9 & 6 & 11 & 73 \\
\hline Extended family $(n=30)$ & 0 & 7 & 0 & 93 \\
\hline
\end{tabular}


TABLE 7.2.B. Length of Time Respondents Have Been at Their Current Residence, by Life Cycle Segments

Number of Homeowners (in 1000s)

Heating Fuel Electric $(n=1173)$

Life Cycle Segment

Young adults childless $(n=86)$

Middle aged adults

childless $(n=276)$

Mixed generation adults

childless $(n=74)$

Retired childless $(n=187)$

Eariy parenthood

youngest child $<5 \quad(n=234)$

Late parenthood

youngest child $>6 \quad(n=291)$

Extended family $(n=24)$
Length of Time At Current Residence

\begin{tabular}{cccc}
\hline $\begin{array}{c}\text { Less } \\
\text { than } \\
\text { One Year }\end{array}$ & $\begin{array}{c}1-2 \\
\text { Years }\end{array}$ & $\begin{array}{c}3-4 \\
\text { Years }\end{array}$ & $\begin{array}{c}5 \text { or } \\
\text { more } \\
\text { Years }\end{array}$ \\
\hline $49 \%$ & $10 \%$ & $\frac{18 \%}{23 \%}$ & $\frac{10}{23 \%}$
\end{tabular}

11

8

8

73

6

13

5

76

4

6

6

85

28

6

19

47

10

7

12

71

0
0

0

lived at their current residences for five years or more except for the Young Adults-Childless and Early Parenthood segments. The Young Adult-Childiess segment appears to be the most mobile. As a group, they had the largest percent who had lived at their current residences for less than one year (41\% from the entire sample, 49\% from households using electricity). The Early Parenthood segment most likely did not settle into current residences until the birth of the youngest child.

Over $70 \%$ of the households within each life cycle segment live in singlefamily detached homes (see Tables 7.3.A. and 7.3.8). The segments most frequently living in mobile homes include Young Adults-Childless (14\% from the entire sample, 19\% from households using electricity), Retired (18\% from the entire sample), and Middie-A.jed Adults-Childless (18\% from households that use electricity). These data are a function of income and mobility, both of which have been already discussed. 
TABLE 7.3.A. Type of Residence, by Life Cycle Segments

\begin{tabular}{|c|c|c|c|c|}
\hline \multirow[b]{2}{*}{$\begin{array}{c}\text { Number of Homeowners (in 1000s) } \\
\text { Al1 Heating Fuels ( } n=1987 \text { ) } \\
\text { Life Cycle Segment } \\
\end{array}$} & \multicolumn{4}{|c|}{ Type of Residence } \\
\hline & $\begin{array}{c}\text { Single- } \\
\text { Family } \\
\text { Detached } \\
\text { Home } \\
\end{array}$ & $\begin{array}{l}\text { 2-4 Family } \\
\text { Home-Duplex- } \\
\text { Townhouse }\end{array}$ & $\begin{array}{l}\text { Building } \\
\text { With } \\
\text { More Than } \\
4 \text { Units } \\
\end{array}$ & $\begin{array}{l}\text { Mobile } \\
\text { Home- } \\
\text { Trailer }\end{array}$ \\
\hline Young adults childless $(n=154)$ & $84 \%$ & $0 \%$ & $2 \%$ & $14 \%$ \\
\hline $\begin{array}{l}\text { Middle aged aduits } \\
\text { childless }(n=538)\end{array}$ & 88 & 1 & 0 & 11 \\
\hline $\begin{array}{l}\text { Mixed generation adults } \\
\text { childless }(n=163)\end{array}$ & 95 & 2 & 0 & 4 \\
\hline Retired childless ( $n=283$ ) & 77 & 4 & 2 & 18 \\
\hline $\begin{array}{l}\text { Early parenthood } \\
\text { youngest child }<5 \quad(n=367)\end{array}$ & 89 & 2 & 1 & 8 \\
\hline $\begin{array}{l}\text { Late parenthood } \\
\text { youngest child }>6 \quad(n=453)\end{array}$ & 92 & 3 & 0 & 5 \\
\hline Extended family $(n=30)$ & 100 & 0 & 0 & 0 \\
\hline
\end{tabular}

TABLE 7.3.B. Type of Residence, by Life Cycle Segments

\begin{tabular}{|c|c|c|c|c|}
\hline \multirow[b]{2}{*}{$\begin{array}{c}\text { Number of Homeowners (in 1000s) } \\
\text { All heating Fuels (n=1987) } \\
\text { Life Cycle Segment }\end{array}$} & \multicolumn{4}{|c|}{ Type of Residence } \\
\hline & $\begin{array}{l}\text { Single- } \\
\text { Family } \\
\text { Detached } \\
\text { Home } \\
\end{array}$ & $\begin{array}{l}2-4 \text { Family } \\
\text { Home-Duplex- } \\
\text { Townhouse }\end{array}$ & $\begin{array}{l}\text { Bufiding } \\
\text { With } \\
\text { More Than } \\
4 \text { Units } \\
\end{array}$ & $\begin{array}{l}\text { Mobile } \\
\text { Home- } \\
\text { Traile- } \\
\end{array}$ \\
\hline Young adults childiess $(n=86)$ & $77 \%$ & $0 \%$ & $4 \%$ & $19 \%$ \\
\hline $\begin{array}{l}\text { Middle aged aduits } \\
\text { childiess }(n=273)\end{array}$ & 82 & 0 & I & 18 \\
\hline $\begin{array}{l}\text { Mixed generation adults } \\
\text { childiess }(n=74)\end{array}$ & 93 & 4 & 0 & 3 \\
\hline Retired childiess $(n=187)$ & 72 & 5 & 2 & 2 \\
\hline $\begin{array}{l}\text { Eariy parenthood } \\
\text { youngest child }<5 \quad(n=236)\end{array}$ & 88 & 1 & 1 & 9 \\
\hline $\begin{array}{l}\text { Late parenthood } \\
\quad \text { youngest child }>6 \quad(n=291)\end{array}$ & 92 & 2 & 0 & 6 \\
\hline Extended family $(n=24)$ & 100 & 0 & 0 & 0 \\
\hline
\end{tabular}


Regarding the ways energy use at home can be reduced, the life cycle segments appeared to differ. All of the life cycle segments in the entire sample, with the exception of the Extended Family, most frequently preferred changing their way of living rather than spending money on improvements in their homes (see Table 7.4.A). In the Extended Family segment, $50 \%$ of the households preferred to spend money on improvements, while $41 \%$ preferred to change their way of living. In households using electricity, the Extended Family again more frequentiy preferred spending money on improvements rather than change their way of living (52\% versus $40 \%$ ) (see Table 7.4.8). The Mixed Generation Adults and Late Parenthood segments were evenly split between spending money and changing the way they tive. The rest of the segments favored changing their way of living. Most important is the fact that between $23 \%$ and $52 \%$ of the households within each segment preferred to spend money on improvements to reduce energy use in the home. This fact combined with the information on

TABLE 7.4.A. Ways to Reduce Energy Use at Home, by Life Cycle Segments

\begin{tabular}{|c|c|c|c|c|}
\hline $\begin{array}{c}\text { Number of Homeowners (in 1000s) } \\
\text { All Heating Fuels ( } n=1938) \\
\text { Life Cycle Segment }\end{array}$ & $\begin{array}{l}\text { Ways to } \\
\text { Spend Money } \\
\text { on } \\
\text { Improvements }\end{array}$ & $\begin{array}{l}\text { Reduce } \\
\text { Change } \\
\text { Way of } \\
\text { Living }\end{array}$ & Both & Neither \\
\hline Young adults childiess $(n=149)$ & $26 \%$ & $61 \%$ & $13 \%$ & $0 \%$ \\
\hline $\begin{array}{l}\text { Middle aged adults } \\
\text { childless }(n=522)\end{array}$ & 39 & 50 & 11 & 0 \\
\hline $\begin{array}{l}\text { Mixed generation adults } \\
\text { childless }(n=155)\end{array}$ & 37 & $5 !$ & 12 & 0 \\
\hline Retired childiess $(n=273)$ & 38 & 47 & 7 & 8 \\
\hline $\begin{array}{l}\text { Eariy parenthood } \\
\text { youngest child }<5 \quad(n=360)\end{array}$ & 30 & 50 & 10 & 0 \\
\hline $\begin{array}{l}\text { Late parenthood } \\
\text { youngest child }>6 \quad(n=449)\end{array}$ & 41 & 49 & 9 & 1 \\
\hline Extended family $(n=30)$ & 50 & 44 & 7 & 0 \\
\hline
\end{tabular}


TABLE 7.4.B. Ways to Reduce Energy Use at Home, by Life Cycle Segments

\begin{tabular}{|c|c|c|c|c|}
\hline \multirow[b]{2}{*}{$\begin{array}{l}\text { Number of Homeowners (in 1000s) } \\
\text { Heating Fuel Electric ( } n=1153 \text { ) } \\
\text { Life Cycle Segment }\end{array}$} & \multicolumn{4}{|c|}{ Ways to Reduce Energy Use } \\
\hline & $\begin{array}{l}\text { Spend Money } \\
\text { on } \\
\text { Improvements }\end{array}$ & $\begin{array}{l}\text { Change } \\
\text { Way of } \\
\text { Living }\end{array}$ & Both & Neither \\
\hline Young adults childless $(n=84)$ & $23 \%$ & $64 \%$ & $14 \%$ & $0 \%$ \\
\hline $\begin{array}{l}\text { Middle aged adults } \\
\text { childless }(n=270)\end{array}$ & 35 & 53 & 13 & 0 \\
\hline $\begin{array}{l}\text { Mixed generation adults } \\
\text { childless }(n=71)\end{array}$ & 40 & 39 & 22 & 0 \\
\hline Retired childiess ( $n=182)$ & 39 & 46 & 11 & 4 \\
\hline $\begin{array}{l}\text { Early parenthood } \\
\text { youngest child }<5 \quad(n=234)\end{array}$ & 26 & 63 & 11 & 0 \\
\hline $\begin{array}{l}\text { Late parenthood } \\
\text { youngest child }>6 \quad(n=287)\end{array}$ & 46 & 44 & 9 & 1 \\
\hline Extended family $(n=24)$ & 52 & 40 & 8 & 0 \\
\hline
\end{tabular}

segments having incomes over $\$ 30,000$ and living at their current residences less than two years indicates that there are segments that should be receptive to promotional campaigns for investing in energy conservation.

Tables 7.5.A and 7.5.B show the family life cycle segments by number of people in the household. The Retired segment most frequentiy had one person in the household ( $52 \%$ from the entire sample, $50 \%$ from households using electricity). Young Adults-Childless and Middle-Aged Adult-Childless most frequently had two persons in the househoids $(56 \%, 62 \%$ from the entire sample, 53\%, 64\% from households using electricity). The Mixed Generation Adult segment most frequentiy had three persons. Most likely, two middle-aged adults and a child 18 years or older was still living at home. Households with children living at home (from both Early and Late Parenthood segments), no matter what the ir ages, most frequently had four persons. Of the Extended Family segment, 70\% had five or more persons in the household. 
TABLE 7.5.A. Number of People in the Household, by Life Cycie Segments Number of Homeowners (in 1000s)

All Heating Fue's $(n=1,987)$ Life Cycle Segment

Young adults childless $(n=154)$

Middle aged adults

childiess $(n=538)$

Mixed generation adults

childless $(n=163)$

Retired childless $(n=283)$

Early parenthood youngest child $<5 \quad(n=367)$

Late parenthood

youngest child $>6 \quad(n=453)$

Extended family $(n=30)$ Number of People in the Household

\begin{tabular}{cccccc}
\hline$\frac{1}{18 \%}$ & $\frac{2}{56 \%}$ & $\frac{3}{7 \%}$ & $\frac{4}{15 \%}$ & $\frac{5}{2 \%}$ & $\frac{6 \text { More }}{3 \%}$ \\
24 & 62 & 5 & 3 & 4 & 2 \\
0 & 28 & 54 & 16 & 0 & 3 \\
52 & 45 & 2 & 2 & 0 & 0 \\
0 & 1 & 23 & 35 & 24 & 17 \\
0 & 8 & 29 & 42 & 13 & 8 \\
0 & 6 & 7 & 17 & 42 & 28
\end{tabular}

TABLE 7.5.B. Number of People in the Household, by Life Cycle Segments

Number of Homeowners (in 1000s) Heating Fuel Electric $(n=1,175)$ Life Cycle Segment

Young aduits childless $(n=86)$

Middle aged adults

childless $(n=276)$

Mixed generation adults

childiess $(n=74)$

Retired childless ( $n=187$ )

Early parenthood

youngest child $<5 \quad(n=236)$

Late parenthood

youngest child $>6 \quad(n=291)$

Extended family $(n=24)$
Number of People in the Household

$\frac{1}{18 \%} \quad \frac{2}{53 \%} \quad \frac{3}{8 \%} \quad \frac{4}{11 \%} \quad \frac{5}{4 \%} \frac{\begin{array}{l}\text { More } \\ 5 \%\end{array}}{0}$

$\begin{array}{llllll}26 & 64 & 6 & 1 & 0 & 3\end{array}$

$\begin{array}{llllll}0 & 33 & 54 & 13 & 0 & 0\end{array}$

$\begin{array}{llllll}50 & 48 & 2 & 0 & 0 & 0\end{array}$

$\begin{array}{llllll}0 & 2 & 24 & 33 & 27 & 14\end{array}$

$\begin{array}{llllll}0 & 7 & 32 & 35 & 14 & 12\end{array}$

$\begin{array}{llllll}0 & 7 & 0 & 21 & 38 & 34\end{array}$ 


\subsection{FAMILY LIFE CYCLE SEGMENTS AND CONSUMER BEHAVIOR AND INTENTIONS TOWARD CONSERVATION INVESTMENT}

The number of ECMs that have been installed by homeowners is broken down by family life cycle segments in Tables 7.6.A and 7.6.B. Data from the Extended Family segment should be reviewed cautiousiy because of the small sample size. The remainder of the discussion has excluded the Extended Family segment because of this limitation. The Late Parenthood segment had the largest percentage of homeowners who have installed between five and seven ECMs and who have total household incomes greater than $\$ 30,000$. Conversely, over 45\% of the Young Adults-Childless households had installed either no or one ECM since moving into their current residences. A partial explanation may be that this segment had the largest proportion having lived at their current residences for less than one year. In time, this segment would be expected to

TABLE 7.6.A. Number of Energy Conservation Measures Installed, by Life Cycle Segments

\begin{tabular}{|c|c|c|c|c|}
\hline \multirow{2}{*}{$\begin{array}{l}\text { Number of Homeowners (in 10D0s) } \\
\text { All Heating Fuels }(n=1987) \\
\text { Life Cycle Segment }\end{array}$} & \multicolumn{4}{|c|}{$\begin{array}{l}\text { Number of Energy } \\
\text { Conservation Measures }\end{array}$} \\
\hline & $0-1$ & $2-4$ & $5-7$ & $\begin{array}{l}8 \text { or } \\
\text { More }\end{array}$ \\
\hline Young aduits chijdless $(n=154)$ & $47 \%$ & $41 \%$ & $12 \%$ & $0 \%$ \\
\hline $\begin{array}{l}\text { Middle aged adults } \\
\text { childless }(n=538)\end{array}$ & 38 & 34 & 24 & 3 \\
\hline $\begin{array}{l}\text { Mixed generation adults } \\
\text { childiess }(n=163)\end{array}$ & 24 & 43 & 27 & 6 \\
\hline Retired childless $(n=283)$ & 36 & 36 & 23 & 4 \\
\hline $\begin{array}{l}\text { Early parenthood } \\
\text { youngest Child }<5 \quad(n=367)\end{array}$ & 40 & 34 & 23 & 3 \\
\hline $\begin{array}{l}\text { Late parenthood } \\
\text { youngest child >6 }(n=453)\end{array}$ & 26 & 40 & 33 & 1 \\
\hline Extended Family $(n=30)$ & 23 & 22 & 26 & 28 \\
\hline
\end{tabular}


TABLE 7.6.B. Number of Energy Conservation Measures Installed, by Life Cycle Segments

\begin{tabular}{|c|c|c|c|c|}
\hline \multirow{2}{*}{$\begin{array}{c}\text { Number of Homeowners (in 1000s) } \\
\text { Heating Fuel Electric ( } \mathrm{n}=1175) \\
\text { Life Cycle Segment }\end{array}$} & \multicolumn{4}{|c|}{ Conservation Measures } \\
\hline & $0-1$ & $2-4$ & $5-7$ & $\begin{array}{l}8 \text { or } \\
\text { More }\end{array}$ \\
\hline Young adults childless $(n=86)$ & $46 \%$ & $38 \%$ & $17 \%$ & $0 \%$ \\
\hline $\begin{array}{l}\text { Middle aged adults } \\
\text { childless ( } n=276)\end{array}$ & 40 & 34 & 24 & 2 \\
\hline $\begin{array}{l}\text { Mixed generation adults } \\
\text { childless }(n=74)\end{array}$ & 28 & 37 & 30 & 4 \\
\hline Retired childless $(n=187)$ & 36 & 37 & 21 & 6 \\
\hline $\begin{array}{l}\text { Early parenthood } \\
\text { youngest Child }<5 \quad(n=236)\end{array}$ & 41 & 32 & 23 & 5 \\
\hline $\begin{array}{l}\text { Late parenthood } \\
\text { youngest Child }>6 \quad(n=291)\end{array}$ & 29 & 39 & 31 & 1 \\
\hline Extended Family $(n=24)$ & 15 & 19 & 32 & 34 \\
\hline
\end{tabular}

increase their conservation efforts. Except for the Extended Family segment, $6 \%$ or less of each of the segments had installed eight or more ECMs since moving into their current residences.

A relationship is apparent between family life cycle segments and homeowners' likelihood of installing ECMs in the next two to three years. The Retired segment was the largest group to state that they are somewhat or very likely to install no ECMs in the next two to three years (75\% from entire sample and from households using electricity) (see Tables 7.7.A and 7.7.8). The segments with the largest percentages of households indicating that they are somewhat or very likely to install three or more ECMs include Young AdultsChildless (50\% from entire sample, 53\% from househoids using electricity), Early Parenthood (33\% from entire sample, 24\% from households using electricity), and Late Parenthood (29\% from entire sample, 27\% from housenolds using electricity). All of these life cycle segments are those having a moderate 
TABLE 7.7.A. Number of Energy Conservation Measures Homeowners are Somewhat or Very Likely to Install in the Next Two to Three Years, by Life Cycle Segments

\begin{tabular}{|c|c|c|c|}
\hline \multirow{2}{*}{$\begin{array}{l}\text { Number of Homeowners (in 1000s) } \\
\text { All Heating Fuels ( } n=1987) \\
\text { Life Cycle Segment }\end{array}$} & \multicolumn{3}{|c|}{$\begin{array}{c}\text { Number of Energy } \\
\text { Conservation } \\
\text { Measures Somewhat } \\
\text { or Very } \\
\text { Likely to Install }\end{array}$} \\
\hline & 0 & $\underline{1-2}$ & $\begin{array}{l}3 \text { or } \\
\text { More } \\
\end{array}$ \\
\hline Young adults childless $(n=154)$ & $10 \%$ & $40 \%$ & $50 \%$ \\
\hline $\begin{array}{l}\text { Middle aged adults } \\
\text { childless }(n=538)\end{array}$ & 40 & 43 & 17 \\
\hline $\begin{array}{l}\text { Mixed generation adults } \\
\text { childiess }(n=163)\end{array}$ & 35 & 45 & 20 \\
\hline Retired childless ( $n=283$ ) & 75 & 20 & 5 \\
\hline $\begin{array}{l}\text { Early parenthood } \\
\text { youngest Child }<5 \quad(n=367)\end{array}$ & 19 & 49 & 33 \\
\hline $\begin{array}{l}\text { Late parenthood } \\
\text { youngest Child } 26 \quad(n=453)\end{array}$ & 29 & 42 & 29 \\
\hline Extended Family $(n=30)$ & 11 & 65 & 24 \\
\hline
\end{tabular}

amount of money, and except for the Late Parenthood segment, have not lived very long at their current residences. Thus, they are looking ahead and are beginning to establish their homes.

\subsection{SUMMARY}

The results indicate that consumer behavior and intentions toward conservation do vary by the family life cycle a household currentiy finds itself. Therefore the hypothesis can be rejected. The two life cycle segments that appear most receptive and capable of installing ECMs are the Young AdultsChildiess and Early Parenthood. These segments have moderately high incomes, shorter length of stay at current residences compared to other segments, fewer ECMs installed, and the greatest likelihood of installing three or more ECMs in 
TABLE 7.7.B. Number of Energy Conservation Measures Homeowners are Somewhat or Very Likely to Install in the Next Two to Three Years, by Life Cycle Segments

\begin{tabular}{|c|c|c|c|}
\hline \multirow{2}{*}{$\begin{array}{c}\text { Number of Homeowners (in 1000s) } \\
\text { Heating Fuel Electric ( } n=1175) \\
\text { Life Cycle Segment }\end{array}$} & \multicolumn{3}{|c|}{$\begin{array}{l}\text { Number of Energy } \\
\text { Conservation } \\
\text { Measures Somewhat } \\
\text { or Very } \\
\text { Likely to Install }\end{array}$} \\
\hline & 0 & $1-2$ & $\begin{array}{l}3 \text { or } \\
\text { More }\end{array}$ \\
\hline Young adults childless $(n=86)$ & $8 \%$ & $40 \%$ & $53 \%$ \\
\hline $\begin{array}{l}\text { Middle aged adults } \\
\text { childless }(n=276)\end{array}$ & 43 & 42 & 15 \\
\hline $\begin{array}{l}\text { Mixed generation adults } \\
\text { childless }(n=74)\end{array}$ & 33 & 53 & 14 \\
\hline Retired childless $(n=187)$ & 75 & 18 & 7 \\
\hline $\begin{array}{l}\text { Early parenthood } \\
\text { youngest Child }<5 \quad(n=236)\end{array}$ & 22 & 54 & 24 \\
\hline $\begin{array}{l}\text { Late parenthood } \\
\text { youngest child } \neq 6 \quad(n=291)\end{array}$ & 28 & 45 & 27 \\
\hline Extended Family $(n=24)$ & 13 & 71 & 17 \\
\hline
\end{tabular}

the future. Marketing programs should be geared towards the demographic data availabie on these two segments. Both segments are composed of young adults, and the Early Parenthood group also has children. Advertising ECMs may be more successful if the advertising depicts families similar to the Young AdultChildless and Early Parenthood segments.

\subsection{VALUE, ATTITUDE AND LITESTYLE SEGMENTS--METHODOLOGY}

Factor analysis is a multivariate statistical technique used to reduce the number of variables in a data set and to summarize patterns of intercorrelations among variables. This statistical technique was used to analyze the valve, attitude and lifestyle statements in the Phase II survey. The analysis indicated that there were two factors accounting for approximately $52 \%$ of the 
variance in the variables. These two factors measured the leveis of cynicism and altruism that homeowners may have felt toward several of the value, attitude, and lifestyle statements.

Questions highly correlated within the cynicism factor include:

1. Utilities should stop offering a variety of programs to encourage energy conservation.

2. It is silly to conserve electricity because the electric utility just turns around and charges more for what you do use.

3. With the current surplus in the Northwest, there is no need to conserve electricity.

4. My conservation efforts will not have much effect one way or the other on the availability of electricity. Questions highly correlated within the altruism factor include:

1. Conserving energy is the best way to protect the environment.

2. It is our responsibility to conserve electricity for future generations.

3. Conserving electricity is the best way to maintain my lifestyle. Each respondent received two factor scores, one for the cynicism factor and one for the altruism factor. For purposes of this report, the factor scores were coded into low and high depending on whether the score was positive or negative on the particular factor. For example, a high cynicism score would indicate that the respondent tended to agree or strongly agree with the questions indicating cynicism and tended to rate other statements less strongly. Further refinements to this coding scheme, may be appropriate in future analyses.

\subsection{DEMOGRAPHIC BREAKDOWN OF CYNICISM AND ALTRUISM FACTORS}

A slight relationship was apparent between homeowners' leveis of cynicism and their total household incomes (see Tables 7.8.A and 7.8.B). The entire sample/households using electricity and those who scored high on the cynicism 
TABLE 7.8.A. Total Household Income, by Cynicism Factor

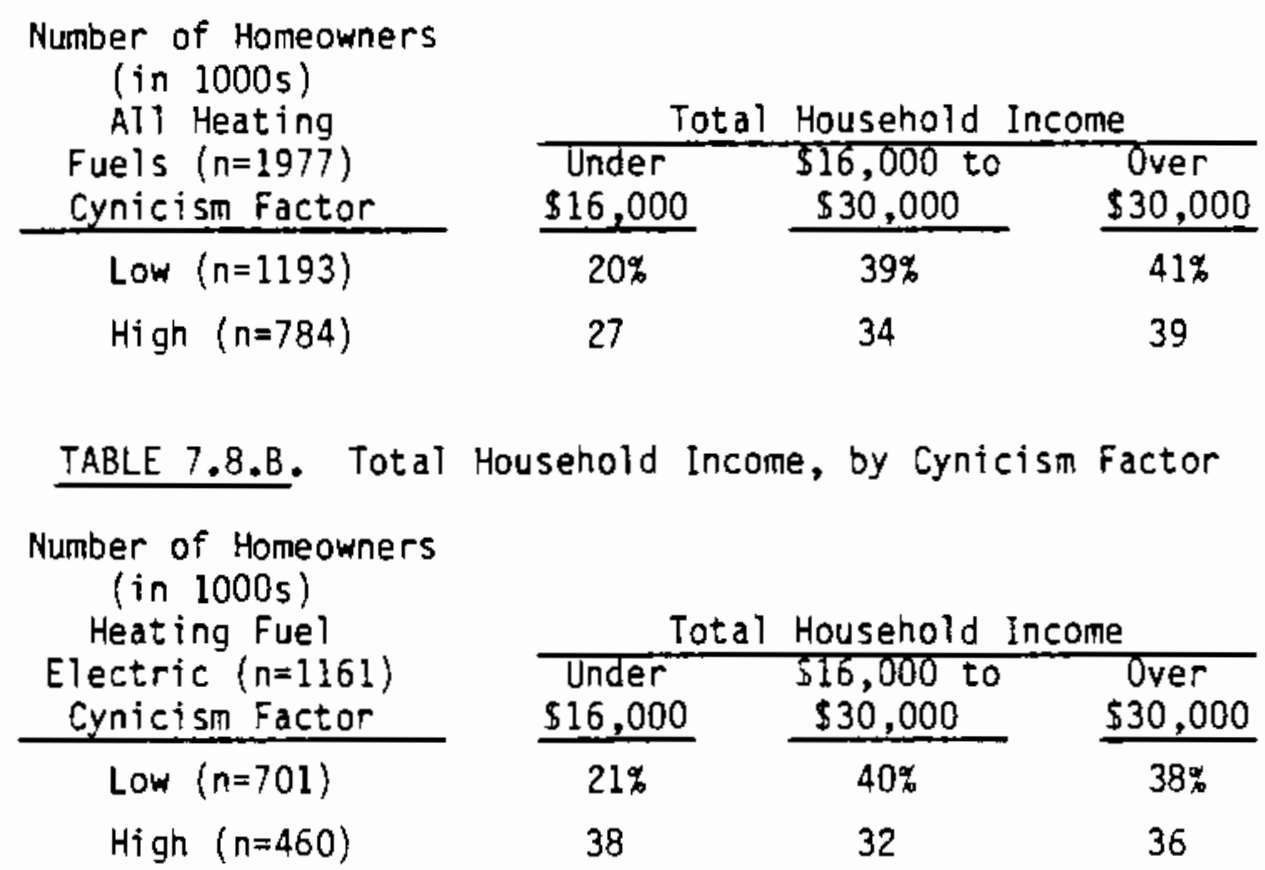

factor tended to have a higher representation in the low-income groups than those who scored low on the cynicism factor $127 \%$ versus $20 \%$ from entire sample, $38 \%$ versus $21 \%$ from households using electric homes). No relationship was apparent between the homeowner's level of cynicism and the length of time they had $l$ ived at the current residence (see Tables 7.9.A and 7.9.B). Over 65\% of homeowners from the entire sample and from households using electricity and of those who scored low or high on the cynicism factor had lived at their current residences for five years or longer.

TABLE 7.9.A. Length of Time Homeowners Have Been at the Current Residence, by Cynicism Factor

Number of Homeowners

\begin{tabular}{l} 
(in lo00s) \\
All Heating \\
Fuels ( $n=2148$ ) \\
Cynicism Factor \\
\hline Low $(n=131 B)$ \\
High $(n=830)$
\end{tabular}

$$
\text { (in 1000s) }
$$

Alt Heating

Fuels $(n=2148)$

Cynicism factor

High $(n=830)$

\begin{tabular}{cccc}
\multicolumn{2}{c}{ Length of Time at } & \multicolumn{3}{c}{$\begin{array}{c}5 \text { or } \\
\text { Less Than }\end{array}$} & $1-2$ & $3-4$ & $\begin{array}{c}\text { More } \\
\text { One Year }\end{array}$ & Years & Years & Years \\
\cline { 2 - 3 } & $72 \%$ & $11 \%$ & $71 \%$ \\
14 & 7 & 12 & 68
\end{tabular}


TABLE 7.9.B. Length of Time Homeowners Have Been at the Current Residence, by Cynicism Factor

Number of Homeowners

(in 1000s)

Heating Fue 1

E.lectric $(n=1261)$

Cynicism Factor

Low $(n=770)$

High $(n=490)$ $\frac{\text { Length of Time at Current Residence }}{5 \text { or }}$

Less Than 1-2 $3-4$ More

$\frac{\text { One Year }}{14 \%} \quad \frac{\text { Years }}{7 \%} \quad \frac{\text { Years }}{12 \%} \quad \frac{\text { Years }}{67 \%}$

15

7

11

67

Homeowners' level of cynicism by type of residence can be seen in

Tables 7.10.A and 7.10.B. Over $80 \%$ of the homeowners from the entire sample and from households using electricity and of those who scored low or high on the cynicism factor live in single-family detached homes and between $9 \%$ and $14 \%$ live in mobile home trailers.

A relationship is apparent between the preferred method to reduce energy use in the home and the homeowner's level of cynjcism (see Tables 7.11.A and 7.11.B). Homeowners from the entire sample and from households using

TABLE 7.10.A. Type of Residence, by Cynicism Factor

Number of Homeowners

(in 1000s)

All Heating

Fueis $(n=2150)$

Cynicism Factor

Low $(n=1320)$

High $(n=830)$
Type of Current Residence

\begin{tabular}{|c|c|c|c|}
\hline $\begin{array}{l}\text { Single-Family } \\
\text { Detached Home }\end{array}$ & $\begin{array}{r}2-4 \text { Family } \\
\text { Home Duplex- } \\
\text { Townhouse } \\
\end{array}$ & $\begin{array}{c}\text { Building } \\
\text { with } \\
\text { More than } \\
\text { Four Units } \\
\end{array}$ & $\begin{array}{l}\text { Mobile } \\
\text { Home } \\
\text { Trailers } \\
\end{array}$ \\
\hline $89 \%$ & $1 \%$ & $1 \%$ & $9 \%$ \\
\hline 85 & 3 & 1 & 12 \\
\hline
\end{tabular}

TABLE 7.10.B. Type of Residence, by Cynicism Factor

Number of Homeowners

(in 1000s)

Heating Fuel

Electric $(n=1262)$

Cynicism Factor

Low $(n=772)$

High $(n=490)$
Type of Current Residence

\begin{tabular}{|c|c|c|c|}
\hline $\begin{array}{l}\text { Single-Family } \\
\text { Detached Home }\end{array}$ & $\begin{array}{l}2-4 \text { Family } \\
\text { Home Duplex- } \\
\text { Townhouse }\end{array}$ & $\begin{array}{l}\text { Building } \\
\text { with } \\
\text { More than } \\
\text { Four Units } \\
\end{array}$ & $\begin{array}{l}\text { Mobile } \\
\text { Home } \\
\text { Trailers } \\
\end{array}$ \\
\hline $84 \%$ & $2 \%$ & $1 \%$ & $13 \%$ \\
\hline 83 & 2 & 1 & 14 \\
\hline
\end{tabular}


TABLE 7.11.A. Ways to Reduce Energy Use at Home, by Cynicism Factor Number of Homeowners (in 1000s)

All Heating

Fuels $(n=2092)$

Cynicism Factor

Low ( $n=1286)$

High $(n=806)$

\begin{tabular}{cccc}
\multicolumn{4}{c}{ Ways to Reduce Energy Use } \\
$\begin{array}{c}\text { Spend Money } \\
\text { on }\end{array}$ & $\begin{array}{c}\text { Change } \\
\text { Way of } \\
\text { Living }\end{array}$ & $\frac{\text { Both }}{11 \%}$ & $\frac{\text { Neither }}{1 \%}$ \\
$\frac{1}{34 \%}$ & $54 \%$ & $1 \%$ & 3 \\
40 & 49 & 8 & 3
\end{tabular}

TABLE 7.11.B. Ways to Reduce Energy Use at Home, by Cynicism Factor Number of Homeowners

(in 1000s)

Heating Fuel

Electric ( $n=1232)$

Cynicism Factor

Low $(n=751)$

High $(n=481)$

$\begin{array}{cc}\text { Ways to Reduce Energy Use } \\ \begin{array}{c}\text { Spend Money } \\ \text { On }\end{array} & \begin{array}{c}\text { Wange } \\ \text { Way of }\end{array}\end{array}$

Improvements Living

$34 \%$

38
$53 \%$

48

$\frac{\text { Both }}{12 \%} \quad \frac{\text { Neither }}{1 \%}$

12

2

electricity who scored high on the cynicism factor had a stronger preference for spending money on improvements than did those who scored low on the cynicism factor $140 \%$ versus $34 \%$ from entire sample, $38 \%$ versus $34 \%$ from households using electricity). Conversely, homeowners who scored low on the cynicism factor had a stronger preference for changing their way of living compared to those who scored high on the cynicism factor (54\% versus $49 \%$ from entire sample, 53\% versus $48 \%$ from househoids using electricity). Between $8 \%$ and $12 \%$ of the homeowners who scored low or high on the cynicism factor preferred both methods of reducing energy use, while between $1 \%$ and $3 \%$ of the same respondents preferred neither method.

A positive relationship is apparent between homeowners' total household incomes and their levels of altruism, especially for the low altruism group (see Tabies 7.12.A and 7.12.B). Homeowners who scored high on the altruism factor more frequently had incomes less than $\$ 16,000$ than did homeowners who scored low on the altruism factor (28\% versus $19 \%$ from entire sample, $33 \%$ versus $19 \%$ from housenolds using electricity). Conversely, those wno scored 
IABLE 7.12.A. Total Household Income, by Altruism Factor

Number of Homeowners

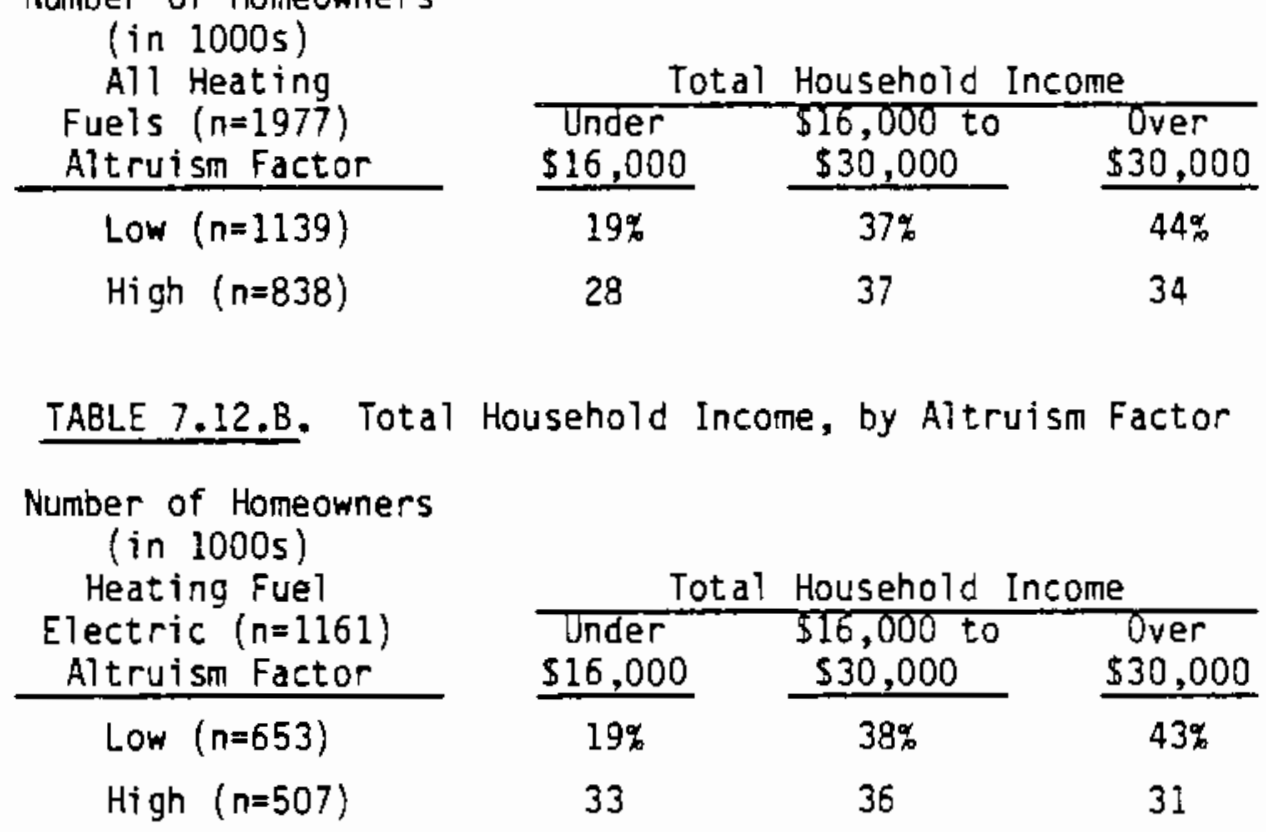

low on the altruism factor more frequently had incomes greater than $\$ 30,000$ than did those homeowners who scored high on the altruism factor (44\% versus $34 \%$ from entire sample, $43 \%$ versus $31 \%$ from households using electricity).

No relationship was apparent between length of time the homeowners had been at current residences and leveis of altruism (see Table 7.13.A and Table 7.13.8). Over $65 \%$ of the homeowners who scored high or low on the a]truism factor had iived at their current residences for five years or ionger.

TABLE 7.13.A. Length of Time Homeowners Have Been at Their Current Residence, by Altruism Factor

Number of Homeowners

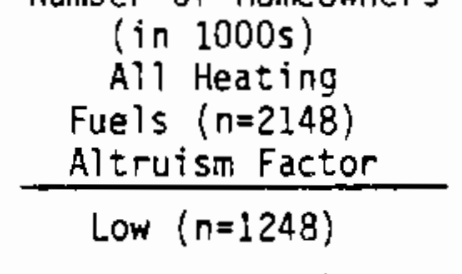

High $(n=900)$

\begin{tabular}{|c|c|c|c|}
\hline $\begin{array}{l}\text { Less Than } \\
\text { One Year } \\
\end{array}$ & $\begin{array}{c}1-2 \\
\text { Years } \\
\end{array}$ & $\begin{array}{c}3-4 \\
\text { Years } \\
\end{array}$ & $\begin{array}{l}5 \text { or } \\
\text { More } \\
\text { Years } \\
\end{array}$ \\
\hline $11 \%$ & $8 \%$ & $12 \%$ & $68_{r}^{\alpha}$ \\
\hline 14 & 6 & 9 & 71 \\
\hline
\end{tabular}


TABLE 7.13.B. Length of Time Homeowners Have Been at Their Current Residence, by Altruism Factor

Number of Homeowners

(in 1000s)

Heating Fuel

Electric $(n=1261)$

Altruism Factor

Low $(n=707)$

High $(n=554)$
Length of Time at Current Residence

\begin{tabular}{|c|c|c|c|}
\hline $\begin{array}{l}\text { Less Than } \\
\text { One Year }\end{array}$ & $\begin{array}{c}1-2 \\
\text { Years } \\
\end{array}$ & $\begin{array}{c}3-4 \\
\text { Years } \\
\end{array}$ & $\begin{array}{l}5 \text { or } \\
\text { More } \\
\text { Years } \\
\end{array}$ \\
\hline $12 \%$ & $7 \%$ & $13 \%$ & $68 \%$ \\
\hline 18 & 7 & 9 & 66 \\
\hline
\end{tabular}

With regard to the altruism factor, over $80 \%$ of the homeowners live in single-family detached homes, and between $8 \%$ and $16 \%$ live in mobile home trailers (see Tables 7.14.A and 7.14.B). These percentages from types of residences paraliel those of the cynicism factor. Again, parallel to percentages of the cynicism factor, altruism factor percentages show that homeowners most frequently prefer to change their way of living rather than spend money on improvements in order to reduce energy use in their home (see Tables 7.15.A and 7.15.B). Between $48 \%$ and $55 \%$ of the homeowners who scored high or low on

TABLE 7.14.A. Type of Residence, by Altruism Factor

\begin{tabular}{|c|c|c|c|c|}
\hline \multirow[b]{2}{*}{$\begin{array}{l}\text { Number of Homeowners } \\
\text { (in lo00s) } \\
\text { All Heating } \\
\text { Fuels ( }=2150) \\
\text { Altruism Factor } \\
\end{array}$} & \multicolumn{4}{|c|}{ Type of Current Residence } \\
\hline & $\begin{array}{l}\text { Single-Family } \\
\text { Detached Home }\end{array}$ & $\begin{array}{l}2-4 \text { Family } \\
\text { Home Duplex- } \\
\text { Townhouse } \\
\end{array}$ & $\begin{array}{c}\text { Building } \\
\text { with } \\
\text { More than } \\
\text { Four Units }\end{array}$ & $\begin{array}{l}\text { Mobile } \\
\text { Home } \\
\text { Trailers } \\
\end{array}$ \\
\hline Low $(n=1250)$ & $89 \%$ & $1 \%$ & $1 \%$ & $8 \%$ \\
\hline High $(n=900)$ & 85 & 2 & 0 & 12 \\
\hline
\end{tabular}

TABLE 7.14.B. Type of Residence, by Altruism Factor

Number of Homeowners

(in 1000s)

Heating Fuel

Electric $(n=1262)$

Altruism Factor

Low $(n=709)$

Type of Current Residence

High $(n=554)$

\begin{tabular}{|c|c|c|c|}
\hline $\begin{array}{l}\text { Single-Family } \\
\text { Detached Home }\end{array}$ & $\begin{array}{c}2-4 \text { Family } \\
\text { Home Duplex- } \\
\text { Townhouse } \\
\end{array}$ & $\begin{array}{c}\text { Building } \\
\text { with } \\
\text { More than } \\
\text { Four Units } \\
\end{array}$ & $\begin{array}{l}\text { Mobile } \\
\text { Home } \\
\text { Trajlers } \\
\end{array}$ \\
\hline $85 \%$ & $2 \%$ & $1 \%$ & $11 \%$ \\
\hline 82 & 1 & 0 & 16 \\
\hline
\end{tabular}


TABLE 7.15.A. Ways to Reduce Energy Use at Home, by Altruism Factor

Number of Homeowners

(in 1000s)

Al] Heating

Fuels $(n=2091)$

A]truism Factor

Low $(n=1214)$

High $(n=878)$

\begin{tabular}{|c|c|c|c|}
\hline $\begin{array}{l}\text { Spend Money } \\
\text { on } \\
\text { Improvements }\end{array}$ & $\begin{array}{l}\text { Change } \\
\text { Way of } \\
\text { Living }\end{array}$ & Both & Neither \\
\hline $37 \%$ & $50 \%$ & $11 \%$ & $1 \%$ \\
\hline 35 & 54 & 9 & 2 \\
\hline
\end{tabular}

TABLE 7.15.8. Ways to Reduce Energy Use at Home, by Altruism Factor

Number of Homeowners

(in 1000s)

Heating Fue?

Electric $(n=1232)$

Altruism Factor

Low $(n=692)$

High $(n=541)$

\begin{tabular}{|c|c|c|c|}
\hline $\begin{array}{c}\text { Spend Money } \\
\text { on } \\
\text { Improvements }\end{array}$ & $\begin{array}{l}\text { Change } \\
\text { Way of } \\
\text { Living }\end{array}$ & Both & Neither \\
\hline $38 \%$ & $48 \%$ & $13 \%$ & $1 \%$ \\
\hline 33 & 55 & 10 & 1 \\
\hline
\end{tabular}

the altruism factor preferred to change their ways of 1 iving, and between $33 \%$ and $38 \%$ preferred to spend money on improvement. Between $9 \%$ and $13 \%$ preferred to do both, and $2 \%$ or less preferred to do neither.

\subsection{CYNICISM AND ALTRUISM FACTORS RELATED TO CONSUMER BEHAVIOR AND} INTENTIONS TOWARD ENERGY CONSERVATION

A reiationship was apparent between the number of ECMs previousiy installed the level of cynicism of respondents (see Tables 7.16.A and 7.16.8). Homeowners in the entire sample who scored high on the cynicism factor installed one or no ECMs more frequently than those who scored low on the cynicism factor $(37 \%$ versus $33 \%$ ). The opposite was true for homeowners who installed between five and seven ECMs. Approximately $30 \%$ of homeowners from the entire sample and households using electricity who scored low on the cynicism factor installed between five and seven measures, while approximately 20\% of the homeowners who scored high on the cynicism factor installed that same number. 
TABLE 7.16.A. Number of Energy Conservation Measures Installed, by Cynicism Factor

Number of Homeowners

(in 1000s)

All Heating

Fuels $(n=2150)$

Cynicism Factor

Low $(n=1320)$

High $(n=830)$
Number of Energy

Conservation Measures

\begin{tabular}{|c|c|c|c|}
\hline $0-1$ & $2-4$ & $5-7$ & $\begin{array}{l}8 \text { or } \\
\text { More }\end{array}$ \\
\hline $33 \%$ & $36^{\circ}$ & $30 \%$ & $4 \%$ \\
\hline 37 & 40 & 22 & 2 \\
\hline
\end{tabular}

TABLE 7.16.B. Number of Energy Conservation Measures Installed, by Cynicism Factor

\section{Number of Homeowners}

(in 1000s)

Heating Fue?

Electric $(n=1262)$

Cynicism Factor

Low $(n=772)$

High $(n=490)$
Number of Energy Conservation Measures

$\begin{array}{llll}\frac{0-1}{36 \%} & \frac{2-4}{30 \%} & \frac{5-7}{30 \%} & \frac{8 \text { or }}{\text { More }} \\ 35 & 43 & 20 & 2\end{array}$

No relationship appeared to exist between homeowners' level of cynicism and the number of ECMs they are somewhat or very likely to instali in the next two to three years (see Tables 7.17. A and 7.17.B). Between $36 \%$ and $39 \%$ of the homeowners who scored high or low reported that they were not very likely to

TABLE 7.17.A. Number of Energy Conservation Measures Homeowners are Somewhat or Very Likely to Install in the Next Two to Three Years, by Cynicism Factor

Number of Homeowners

(in 1000s)

All Heating

Fuels $(n=2150)$

Cynicism Factor

Low ( $n=1320)$

Hign $(n=830)$
Number of Energy

Conservation

Measures Somewhat or Very

Likely to Install

$\frac{0}{36 \%} \quad \frac{1-2}{39 \%} \quad \frac{\text { More }}{25 \%}$

$38 \quad 42 \quad 20$ 
TABLE 7.17.B. Number of Energy Conservation Measures Homeowners are Somewhat or Very Likely to Install in the Next Two to Three Years, by Cynicism Factor

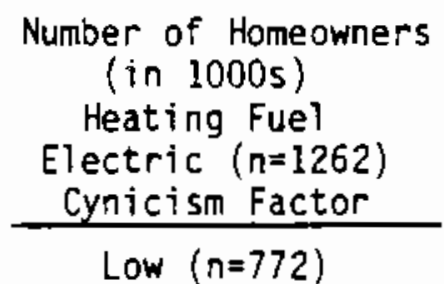

High $(n=490)$
Number of Energy

Conservation

Measures Somewhat or Very Likely to Instal!

$\frac{0}{37 \%} \quad \frac{1-2}{41 \%} \quad \frac{\text { More }}{21 \%}$

$39 \quad 42 \quad 20$

install any ECMs. On the other hand, between $20 \%$ and $25 \%$ of the homeowners who scored high or low on the cynicism factor reported that they were somewhat or very likely to install three or more measures.

Similar to the cynicism factor, a relationship is apparent between the number of EOMs homeowners had installed and their level of altruism, particularly for househoids using electricity (see Tables 7.18.A and 7.18.B). Homeowners who scored low on the altruism factor more frequently had installed 0 or 1 ECMs than had homeowners who scored high on the altruism factor (36\% versus $31 \%$ from entire sample, $39 \%$ versus $32 \%$ from households using electricity). Of the homeowners scoring high on the altruism factor, 5\% had installed eight or more ECMs, while of those scoring low on the altruism factor, only $2 \%$ or less had instalied that number.

TABLE 7.18.A. Number of Energy Conservation Measures Installed, by Altruisin Factor

Number of Homeowners

(in 1000s)

Ali Heating

Fuels $(n=2150)$

Altruism Factor

Low $(n=1250)$

High $(n=890)$
Number of Energy Conservation Measures

$\begin{array}{llll}\frac{0-1}{36 \%} & \frac{2-4}{36 \%} & \frac{5-7}{26 \%} & \frac{8 \text { More }}{1 \%} \\ 31 & 39 & 25 & 5\end{array}$


TABLE 7.1B.B. Number of Energy Conservation Measures Installed, by Altruism Factor

\begin{tabular}{ccccc}
$\begin{array}{c}\text { Number of Homeowners } \\
\text { (in 1000s) } \\
\text { Heating Fuel } \\
\text { Electric (n=1262) } \\
\text { Altruism Factor }\end{array}$ & & \multicolumn{3}{c}{$\begin{array}{c}\text { Number of Energy } \\
\text { Conservation Measures }\end{array}$} \\
\cline { 3 - 5 } Low $(n=709)$ & $\frac{0-1}{39 \%}$ & $\frac{2-4}{32 \%}$ & $\frac{5-7}{27 \%}$ & $\frac{\begin{array}{c}\text { More } \\
2 \%\end{array}}{\text { High }(n=554)}$ \\
\cline { 4 - 6 } & 32 & 40 & 24 & 5
\end{tabular}

A relationship is apparent between the number of ECMs homeowners were somewhat or very likely to install in the next two or three years and their level of altruism (see Tables 7.19.A and 7.19.B). Homeowners who scored high on the altruism factor more frequently reported that they were somewhat or very likely to install no ECMs than those that scored low on the altruism measure (42\% versus $34 \%$ from entire sample, $43 \%$ versus $34 \%$ from househoids using electricity). However, those who scored low on the altruism factor indicated nore frequently that they were somewhat or very likely to install one or two measures than homeowners who scored high on the altruism factor (43\% versus $35 \%$ from entire sample, $45 \%$ versus $37 \%$ from households using electricity). Between $20 \%$ and $23 \%$ of the homeowners who scored high or low on altruism reported that they were somewhat or very likely to install three or more ECMs.

TABLE 7.19.A. Number of Energy Conservation Measures Homeowners are Somewhat or Very Likely to Install in the Next Two to Three Years, by Altruism Factor

\begin{tabular}{|c|c|c|c|}
\hline \multirow{2}{*}{$\begin{array}{l}\text { Number of Homeowners } \\
\text { (in 1000s) } \\
\text { Alt Heating } \\
\text { Fuels ( } n=2150) \\
\text { Altruism Factor } \\
\end{array}$} & \multicolumn{3}{|c|}{$\begin{array}{c}\text { Conservation } \\
\text { Measures Somewhat } \\
\text { or Very } \\
\text { Likely to Install }\end{array}$} \\
\hline & 0 & $1-2$ & $\begin{array}{l}3 \text { or } \\
\text { More }\end{array}$ \\
\hline Low $(n=1250)$ & $34 \%$ & $43 \%$ & $23 \%$ \\
\hline High $(n=900)$ & 42 & 35 & 23 \\
\hline
\end{tabular}


TABLE 7.19.B. Number of Energy Conservation Measures Homeowners are Somewhat or Very Likely to Install in the Two to Three Years, by Altruism Factor

\begin{tabular}{|c|c|c|c|}
\hline \multirow{2}{*}{$\begin{array}{l}\text { Number of Homeowners } \\
\text { (in 1000s) } \\
\text { Heating Fuel } \\
\text { Electric ( } n=1262) \\
\text { Cynicism Factor } \\
\end{array}$} & $\begin{array}{l}\text { No } \\
\text { Med } \\
\text { Lik }\end{array}$ & $\begin{array}{l}r \text { of } \\
\text { serva } \\
\text { es So } \\
\text { r Ver } \\
\text { to }\end{array}$ & $\begin{array}{l}\text { rgy } \\
\text { nat } \\
\text { hat } \\
\text { al1 }\end{array}$ \\
\hline & 0 & $1-2$ & $\begin{array}{l}3 \text { or } \\
\text { More }\end{array}$ \\
\hline Low $(n=709)$ & $34 \%$ & $45 \%$ & $21 \%$ \\
\hline High $(n=554)$ & 43 & 37 & 20 \\
\hline
\end{tabular}

\subsection{SUMMARY}

The results seem to indicate that consumer behavior and intentions toward conservation do vary by the respondents responses to VAL statements which allows for rejection of the hypothesis. Respondents who scored high on the cynicism factor may be more inclined in invest in ECMs than those who scored low. In fact, those with high scores more frequently indicated that they would prefer to spend money on ECMs than did those who scored low. This high cynicism group had installed fewer ECMs in the past and therefore may have more reason to invest. However, this group tends to have lower incomes than those who scored low. There was not much difference between the two groups in terms of the number of ECMs they were likely to install in the next two to three years.

Respondents who scored low on the altruism factor may be more inclined to invest in ECMs than those who scored high. This low group had higher incomes and had installed fewer ECMs than those who scored high on the altruism factor. This group also indicated that they were more inclined to install three or more ECMs in the next two to three years.

The results of the factor analysis should be interpreted with caution because the two factors account for only about $55 \%$ of the variance. in addition, there are wording problems in several of the statements. In future 
analyses, closer scrutiny of the statements with wording problens may result in omitting them from the analyses. Control of additional variables may also increase the percent of variance accounted for. 



\subsection{INFLUENCE OF HOMEOWNER' PERCEPTIONS ANO ATTITUOES ON ENERGY CONSERVATION INVESTMENT}

It is important to know if homeowners' attitudes and perceptions of conservation influence their spending because this knowledge can be used to design a marketing campaign or to position a conservation program for its greatest appeal. For example, assume that it has been determined that homeowners who view conservation spending as a way to increase home value tend to spend more than those who view conservation spending as a way to save on the utility bill. In this instance, a marketing campaign could be designed to emphasize the positive affect conservation investment has on home value. Thus, this campaign would use knowledge of past investment behavior to increase program effectiveness. The purpose of this chapter is, therefore, to determine which attitudes and perceptions of homeowners have a positive influence on the amount spent on energy conservation. And the hypothesis being tested is that the amount of money spent on ECMs will not vary by homeowners' perceptions of conservation.

\subsection{INFLUENCES OF HOMEOWNERS' PERCEPTIONS OF CONSERVATION ON SPENOING FOR ENERGY CONSERYATION}

To detemine if homeowners' perceptions influence their level of spending, their concerns must be examined. Specific levels of concern are related to energy use in the home, cost of energy, and the energy conservation effect produced by energy conservation spending. Four levels of concern are used in this analysis: very concerned, concerned, not very concerned, and not at all concerned. The spending figure used in this analysis is the amount reportedly spent on energy conservation during the last two years. These expenditure responses have been categorized into five levels: $\$ 0, \$ 1$ to $\$ 500, \$ 501$ to $\$ 1,000, \$ 1,001$ to $\$ 2,000$, and $\$ 2,001+$.

\subsubsection{Level of Concern for Energy Use in the Home}

The level of concern a homeowner has regarding energy use in the home appears to affect conservation spending (see Table 8.1.A). A good example of this effect is found in the distribution for ail homeowners who spent nothing 
TABLE 8.1.A. Amount Homeowners Spent During the Past Two Years to Reduce Energy use in Their Home, by Level of Concern for Energy Use

Number of Homeowners

(in 1000s)

All Heating

Fuels ( $n=1482$ )

Amount Spent

$\$ 0(n=660)$

$\$ 1-\$ 500 \quad(n=418)$

$\$ 501-\$ 1000 \quad(n=121)$

$\$ 1001-\$ 200 \quad(n=118)$

$\$ 2001+(n=165)$
Level of Concern for Energy Use In the Home

\begin{tabular}{|c|c|c|c|}
\hline $\begin{array}{c}\text { Very } \\
\text { Concerned }\end{array}$ & Concerned & $\begin{array}{l}\text { Not Very } \\
\text { Concerned }\end{array}$ & $\begin{array}{l}\text { Not at AIT } \\
\text { Concerned }\end{array}$ \\
\hline $32 \%$ & $45 \%$ & $21 \%$ & $2 \%$ \\
\hline 35 & 51 & 12 & 2 \\
\hline 37 & 51 & 12 & 0 \\
\hline 31 & 53 & 16 & 0 \\
\hline 43 & 43 & 11 & 2 \\
\hline
\end{tabular}

on conservation. In this group, $23 \%$ were in the "not very concerned" or "not at all concerned" categories, while less than $16 \%$ of all other spending levels expressed the same lack of concern. This effect is even more visible at the highest level of concern for energy use in the home. Only $32 \%$ of those who spent nothing were "very concerned," while $43 \%$ of those who spent $\$ 2,001$ or more were "very concerned" about energy use in the home.

The subset of homeowners using electric heat (see Table 8.1.B) had a similar response pattern regarding the effect of level of concern on conservation spending. It is apparent, however, that this subset of homeowners is less likely to spend as much on energy conservation as the entire sampie of homeowners. For example, 50\% of the entire subset using electric heat and $45 \%$ of the entire sample spent nothing on ECMs; and only $4 \%$ of the subset spent more than $\$ 2,000$ while $11 \%$ of the entire sample spent over $\$ 2,000$.

\subsubsection{Level of Concern for Cost of Energy}

As shown in Table 8.2.A, homeowners who expressed concern about the cost of energy generally. spent more than those who were less concerned about it. The most observable difference occurs in the "very concerned" category. Of those spending nothing on conservation, $45 \%$ said they were "very concerned" about the cost of energy as compared to $63 \%$ of those who spent $\$ 2,000$ or 
TABLE 8.1.8. Amount Homeowners Spent During the Past Two Years to Reduce Energy Use in Their Home, by Level of Concern for Energy Use

Number of Homeowners

(in 1000s)

Heating Fuel

Electric $(n=492)$ Amount Spent

$\$ 0 \quad(n=247)$

$\$ 1-\$ 500 \quad(n=155)$

$\$ 501-\$ 1000 \quad(n=39)$

$\$ 1001-\$ 200 \quad(n=33)$

$\$ 2001+(n=18)$

$\begin{array}{cccc}\text { Level of Concern for Energy Use In the Home } \\ \frac{\begin{array}{c}\text { Verycerned } \\ 28 \%\end{array}}{\frac{\text { Concerned }}{47 \%}} & \frac{\begin{array}{l}\text { Not Very } \\ \text { Concerned }\end{array}}{24 \%} & \frac{\begin{array}{l}\text { Not at ATा } \\ \text { Concerned }\end{array}}{0 \%}\end{array}$

44

44

63

40
46

51

37

48
11

5

0

11
0

0

0

0

TABLE 8.2.A. Amount Homeowners Spent During the Past Two Years to Reduce Energy Use in Their Home, by Level of Concern for the Cost of Energy

Number of Homeowners

(in 1000s)

All Heating

Fuels ( $n=1487)$ Amount Spent

$\$ 0 \quad(n=665)$

$\$ 1-\$ 500 \quad(n=418)$

$\$ 501-\$ 1000 \quad(n=121)$

$\$ 1001-\$ 200 \quad(n=118)$

$\$ 2001+(n=165)$

\section{Level of Concern for Cost of Energy}

\begin{tabular}{|c|c|c|c|}
\hline $\begin{array}{c}\text { Very } \\
\text { Concerned }\end{array}$ & Concerned & $\begin{array}{l}\text { Not Very } \\
\text { Concerned }\end{array}$ & $\begin{array}{l}\text { Not at ATI } \\
\text { Concerned }\end{array}$ \\
\hline $45 \%$ & $48 \%$ & $5 \%$ & $1 \%$ \\
\hline
\end{tabular}

55

63

41

3

1

37

0

0

59

63
8

6
0

31

0

more. This pattern of higher concern/higher spending is evident in all categories of concern except for the "not very concerned" category. Here, the percentages in the first three spending levels decline. Then at the top two spending levels, the percentages increase. A possible explanation of this variation is that the $6 \%$ to $8 \%$ of those who spent at least $\$ 1,001$ were "not very concerned" about the cost of energy because their homes were already energy efficient. The subset of homeowners using electric heat had essentially the same response pattern (see Table 8.2.B). 
TABLE 8.2.B. Amount Homeowners Spent During the Past Two Years to Reduce Energy Use in Their Home, by Level of Concern for the Cost of Energy

Number of Homeowners

(in 1000s)

Heating Fue?

Electric $(n=489)$

Amount Spent

$\$ 0 \quad(n=244)$
$\$ 1-\$ 500 \quad(n=155)$
$\$ 501-\$ 1000 \quad(n=39)$
$\$ 1001-\$ 200 \quad(n=33)$
$\$ 2001+(n=18)$

\begin{tabular}{|c|c|c|c|}
\hline $\begin{array}{l}\text { Very } \\
\text { Concerned }\end{array}$ & Concerned & $\begin{array}{l}\text { Not Very } \\
\text { Concerned }\end{array}$ & $\begin{array}{l}\text { Not at AIT } \\
\text { Concerned }\end{array}$ \\
\hline $41 \%$ & $54 \%$ & $5 \%$ & $0 \%$ \\
\hline 61 & 38 & 1 & 0 \\
\hline 51 & 49 & 0 & 0 \\
\hline 61 & 29 & 9 & 0 \\
\hline 58 & 31 & 11 & 0 \\
\hline
\end{tabular}

\subsubsection{Level of Concern for Energy Conservation}

Homeowners' level of concern for energy conservation is shown in Table 8.3.A. Again, the greatest difference between spending levels occurs in the "very concerned" category. Oniy $25 \%$ of those who spent nothing responded that they were "very concerned" about energy conservation, while $48 \%$ of those who spent over \$2,000 said they were "very concerned" about energy conservation. The distribution of spending levels in the "concerned", "not very concerned," and "not at all concerned" categories reinforces the pattern that as level of concern for energy conservation increases so does spending. Responses from the

TABLE 8.3.A. Amount Homeowners Spent During the Past Two Years to Reduce Energy Use in Their Home, by Level of Concern for Energy Conservation

Number of Homeowners

\begin{tabular}{|c|c|c|c|c|}
\hline \multirow{2}{*}{$\begin{array}{l}\text { All Heating } \\
\text { Fuels }(n=1483) \\
\text { Amount Spent }\end{array}$} & \multicolumn{4}{|c|}{ Level of Concern for Energy Conservation } \\
\hline & $\begin{array}{l}\text { Very } \\
\text { Concerned } \\
\end{array}$ & Concerned & $\begin{array}{l}\text { Not Very } \\
\text { Concerned }\end{array}$ & $\begin{array}{l}\text { Not at AII } \\
\text { Concerned }\end{array}$ \\
\hline$\$ 0(n=661)$ & $25 \%$ & $62 \%$ & $11 \%$ & $2 \%$ \\
\hline$\$ 1-\$ 500 \quad(n=418)$ & 32 & 61 & 5 & 2 \\
\hline$\$ 501-\$ 1000 \quad(n=121)$ & 28 & 65 & 7 & 0 \\
\hline$\$ 1001-\$ 200 \quad(n=118)$ & 46 & 51 & 3 & 0 \\
\hline$\$ 2001 \div(n=165)$ & 48 & 48 & 4 & 0 \\
\hline
\end{tabular}


subset of homeowners with electric heat are essentially the same as for the entire sample except for the "not very concerned" category. The data in Table 8.3.8 reveals that homeowners in the subset who spent over $\$ 2,000$ were less concerned about energy conservation than were the entire sample of homeowners.

\subsection{INFLUENCES OF HOMEOWNERS' ATTITUDES TOWARDS CONSERVATION ON SPENDING FOR ENERGY CONSERVATION}

The previous section covered homeowners' perceptions regarding conservation and how those perceptions influenced spending. In this section, a series of 15 attitudinal statements and homeowners' responses to them are reviewed. Homeowners were asked to indicate whether they strongly disagreed, disagreed, were neutral, agreed, or strongly agreed with each statement.

\subsubsection{Attitude Toward the Amount of Energy Used}

Homeowners were asked to respond to the statement, "The amount of energy I use is really my own affair and no one else's." A general pattern, shown in Table 8.4.A, suggests that those who had spent nothing tended to agree with this statement to a greater extent than did those at all other spending levels, especially at the highest spending level. For example, $52 \%$ of those who had spent nothing either agreed or strongly agreed with the statement, while only

TABLE 8.3.8. Amount Homeowners Spent During the Past Two Years to Reduce Energy Use in Their Home, by Level of Concern for Energy Conservation

Number of Homeowners

(in 1000s)

Heating Fue?

Electric $(n=492)$

Anount Spent

$\$ 0 \quad(n=247)$

$\$ 1-\$ 500(n=155)$

$\$ 501-\$ 1000 \quad(n=39)$

$\$ 1001-\$ 200 \quad(n=33)$

$\$ 2001+(n=18)$

\begin{tabular}{|c|c|c|c|}
\hline $\begin{array}{c}\text { Very } \\
\text { Concerned }\end{array}$ & Concerned & $\begin{array}{l}\text { Not Very } \\
\text { Concerned } \\
\end{array}$ & $\begin{array}{l}\text { Not at AT } \\
\text { Concerned }\end{array}$ \\
\hline $17 \%$ & $68 \%$ & $13 \%$ & $2 \%$ \\
\hline 35 & 64 & 1 & 0 \\
\hline 34 & 62 & 4 & 0 \\
\hline 52 & 48 & 0 & 0 \\
\hline 42 & 48 & 10 & 0 \\
\hline
\end{tabular}


TABLE 8.4.A. Amount Homeowners Spent During the Past Two Years to Reduce Energy Use in Their Home, by Attitude Toward the Amount of Energy Used

Number of Homeowners

\begin{tabular}{|c|c|c|c|c|c|}
\hline \multirow{2}{*}{$\begin{array}{r}\text { (in 1000s) } \\
\text { All Heating } \\
\text { Fuels }(n=1478) \\
\text { Amount Spent }\end{array}$} & \multicolumn{5}{|c|}{ Response(a) } \\
\hline & $\begin{array}{l}\text { Strongly } \\
\text { Disagree } \\
\end{array}$ & Disagree & Neutral & Agree & $\begin{array}{l}\text { Strongly } \\
\text { Agree }\end{array}$ \\
\hline So $(n=660)$ & $8 \%$ & $37 \%$ & $2 \%$ & $40 \%$ & $12 \%$ \\
\hline$\$ 1-\$ 500 \quad(n=414)$ & 8 & 40 & 4 & 42 & 6 \\
\hline$\$ 501-\$ 1000 \quad(n=121)$ & 12 & 45 & 1 & 32 & 10 \\
\hline$\$ 1001-\$ 2000 \quad(n=118)$ & 9 & 44 & 11 & 24 & 12 \\
\hline$\$ 2001+(n=165)$ & 14 & 44 & 5 & 23 & 14 \\
\hline
\end{tabular}

(a) In response to the statement, "The amount of energy I use is really my own affair and no one else's."

$37 \%$ of those who spent over $\$ 2,000$ agreed or strongly agreed with the statement. The percentages are the opposite for those who disagreed or strongly disagreed with the statement. For example, $58 \%$ of those who spent over $\$ 2,000$ strongly disagreed or disagreed with the statement, while only $45 \%$ of those wno spent nothing disagreed or strongly disagreed with the statement. The subset of homeowners using electric heat responded in like manner, but the pattern tended to be more pronounced (see Table 8.4.8).

\subsubsection{Attitude Toward the Amount of Electricity Used}

Homeowners' responses to, "I only use electricity when it is really needed--there is no way I could cut down," are shown in Table 8.5.A. A pattern similar to the previous pattern emerges, i.e., more respondents who had spent over \$2,000 than those who spent nothing disagreed with the statement. Of the high spending group, 59\% disagreed compared to $46 \%$ of the low spending group. Conversely, about $53 \%$ of the low spending group agreed with the statement, and 39\% of the high spending group agreed. The subset of homeowners using electric heat had a very different response pattern to this statement (see Table 8.5.B). Fewer of those who had spent over \$2,000 than those who spent nothing disagreed 
TABLE 8.4.B. Amount Homeowners Spent During the Past Two Years to Reduce Energy Use in Their Home, by Attitude Toward the Amount of Energy Used

Number of Homeowners

\begin{tabular}{|c|c|c|c|c|c|}
\hline \multirow{2}{*}{$\begin{array}{c}\text { (in 1000s) } \\
\text { Heating Fuel } \\
\text { Electric }(n=492) \\
\text { Amount Spent }\end{array}$} & \multicolumn{5}{|c|}{ Response(a) } \\
\hline & $\begin{array}{l}\text { Strongly } \\
\text { Oisagree } \\
\end{array}$ & Disagree & Neutral & Agree & $\begin{array}{l}\text { Strongiy } \\
\text { Agree } \\
\end{array}$ \\
\hline$\$ 0 \quad(n=247)$ & $11 \%$ & $32 \%$ & $1 \%$ & $44 \%$ & $13 \%$ \\
\hline$\$ 1-\$ 500 \quad(n=155)$ & 7 & 33 & 1 & 44 & 15 \\
\hline$\$ 501-\$ 1000 \quad(n=39)$ & 12 & 51 & 4 & 29 & 4 \\
\hline$\$ 1001-\$ 2000 \quad(n=33)$ & 6 & 45 & 17 & 16 & 16 \\
\hline$\$ 2001+(n=18)$ & 21 & 48 & 0 & 21 & 10 \\
\hline
\end{tabular}

(a) In response to the statement, "The amount of energy I use is really my own affair and no one else's."

TABLE 8.5.A. Amount Homeowners Spent Ouring the Past Two Years to Reduce Energy use in Their Home, by Attitude Toward the Amount of Electricity Used

Number of Homeowners

\begin{tabular}{|c|c|c|c|c|c|}
\hline \multirow{2}{*}{$\begin{array}{l}\text { (in 1000s) } \\
\text { All Heating } \\
\text { Fuels (n=1487) } \\
\text { Amount Spent }\end{array}$} & \multicolumn{5}{|c|}{ Response ${ }^{(a)}$} \\
\hline & $\begin{array}{l}\text { Strongly } \\
\text { Oisagree }\end{array}$ & Disagree & Neutral & Agree & $\begin{array}{l}\text { Strongly } \\
\text { Agree }\end{array}$ \\
\hline$\$ 0 \quad(n=665)$ & $2 \%$ & $44 \%$ & $1 \%$ & $46 \%$ & $7 \%$ \\
\hline$\$ 1-\$ 500 \quad(n=418)$ & 3 & 47 & 3 & 37 & 10 \\
\hline$\$ 501-\$ 1000 \quad(n=121)$ & 0 & 56 & 3 & 23 & 18 \\
\hline$\$ 1001-\$ 2000 \quad(n=118)$ & 13 & 52 & 2 & 26 & 7 \\
\hline$\$ 2001+(n=165)$ & 4 & 55 & 3 & 33 & 6 \\
\hline
\end{tabular}

(a) In response to the statement, "I only use electricity when it's realiy needed--there's no way I could cut down."

with the statement. Only $40 \%$ of those in the high spending group expressed disagreement, while $56 \%$ of the low spending group disagreed. Conversely, about $43 \%$ of the low spending group agreed while $60 \%$ of the high spending group also 
TABLE 8.5.B. Amount Homeowners Spent During the Past Two Years to Reduce Energy Use in Their Home, by Attitude Toward the Amount of Electricity Used

\begin{tabular}{|c|c|c|c|c|c|}
\hline $\begin{array}{c}\text { Number of Homeowner } \\
\text { (in 1000s) } \\
\text { Heating Fuel }\end{array}$ & & & $p_{p o n s e}(a)$ & & \\
\hline $\begin{array}{c}\text { Eiectric }(n=492) \\
\text { Amount Spent } \\
\end{array}$ & $\begin{array}{l}\text { Strongly } \\
\text { Disagree } \\
\end{array}$ & Disagree & Neutral & Agree & $\begin{array}{l}\text { Strongly } \\
\text { Agree }\end{array}$ \\
\hline$\$ 0(n=247)$ & $3 \%$ & $53 \%$ & $2 \%$ & $37 \%$ & $6 \%$ \\
\hline$\$ 1-\$ 500 \quad(n=155)$ & 3 & 51 & 2 & 31 & 13 \\
\hline$\$ 501-\$ 1000 \quad(n=39)$ & 0 & 41 & 9 & 30 & 20 \\
\hline$\$ 1001-\$ 2000 \quad(n=33)$ & 14 & 40 & 0 & 40 & 6 \\
\hline$\$ 2001+(n=18)$ & 0 & 40 & 0 & 50 & 10 \\
\hline
\end{tabular}

(a) In response to the statement, "I on y use electricity when it's really needed--there's no way I could cut down."

agreed with the statement. In general, much stronger agreement with the statement is found among homeowners using electric heat than among homeowners from the entire sample.

\subsubsection{Attitude Toward Ability to Conserve Energy}

The third statement of interest is, "I have already done everything I can to conserve energy." Table 8.6.A, reveals the largest percentage of those in disagreement with the statement are in the medium spending levels rather than the high spending range. Sixty-two percent of those wino spent from $\$ 1$ to $\$ 500$ expressed disagreement, and $79^{\circ}$ of those who spent $\$ 1,001$ to $\$ 2,000$ also disagreed. The subset of homeowners using electric heat disagreed with the statement more often than did the entire sample of homeowners, except for those of the subset who spent over $\$ 2,000$ (see Table 8.6 .8 ). Over haif of this group agreed with the statement.

\subsubsection{Attitilde Toward Consulting Consumer Reports}

Those homeowners who agreed with the statement, "I consult Consumer Reports or similar publications before making major purchases," spent more on energy conservation during the last two years (see Table 8.7.A). The largest percentage of agreement involved those who had spent between $\$ 1,001$ and $\$ 2,000$, 
TABLE 8.6.A. Amount Homeowners Spent During the Past Two Years to Reduce Energy Use in Their Home, by Attitude Toward Ability to Conserve Energy

Number of Homeowners

\begin{tabular}{|c|c|c|c|c|c|}
\hline \multirow{2}{*}{$\begin{array}{r}\text { (in 1000s) } \\
\text { All Heating } \\
\text { Fuels (n=1483) } \\
\text { Amount Spent } \\
\end{array}$} & \multicolumn{5}{|c|}{ Response ${ }^{(a)}$} \\
\hline & $\begin{array}{l}\text { Strongly } \\
\text { Disagree }\end{array}$ & Disagree & Neutra? & Agree & $\begin{array}{c}\text { Strongly } \\
\text { Agree }\end{array}$ \\
\hline$\$ D \quad(n=665)$ & $3 \%$ & $51 \%$ & $3 \%$ & $38 \%$ & $4 \%$ \\
\hline$\$ 1-\$ 500 \quad(n=416\rangle$ & 3 & 59 & 4 & 28 & 6 \\
\hline$\$ 501-\$ 1000 \quad(n=121)$ & 3 & 58 & 0 & 31 & 8 \\
\hline$\$ 1001-\$ 2000 \quad(n=116)$ & 7 & 72 & 0 & 14 & 7 \\
\hline$\$ 2001+(n=165)$ & 4 & 59 & 3 & 28 & 6 \\
\hline
\end{tabular}

(a) In response to the statement, "I have already done everything I can to conserve energy."

TA8LE 8.6.8. Amount Homeowners Spent During the Past Two Years to Reduce Energy Use in Their Home, by Attitude Toward Ability to Conserve Energy

Number of Homeowners

\begin{tabular}{|c|c|c|c|c|c|}
\hline \multirow{2}{*}{$\begin{array}{c}\text { Heating Fuel } \\
\text { Electric }(n=488) \\
\text { Amount Spent }\end{array}$} & \multicolumn{5}{|c|}{ Response $(a)$} \\
\hline & $\begin{array}{l}\text { Strongly } \\
\text { Disagree }\end{array}$ & Disagree & Neutral & Agree & $\begin{array}{l}\text { Strongly } \\
\text { Agree }\end{array}$ \\
\hline$\$ 0(n=247)$ & $1 \%$ & $53 \%$ & $6 \%$ & $37 \%$ & $3 \%$ \\
\hline$\$ 1-\$ 500 \quad(n=153)$ & 4 & 59 & 2 & 26 & 9 \\
\hline$\$ 501-\$ 1000 \quad(n=39)$ & 4 & 68 & 0 & 28 & 0 \\
\hline$\$ 1001-\$ 2000 \quad(n=31)$ & 6 & 88 & 0 & 0 & 5 \\
\hline$\$ 2001+(n=18)$ & 0 & 48 & 0 & 31 & 21 \\
\hline
\end{tabular}

(a) In response to the statement, "I have already done everything I can to conserve energy." 
TABLE 8.7.A. Amount Homeowners Spent During the Past Two Years to Reduce Energy Use in Their Home, by Attitude Toward Consulting Consumer Reports

Number of Homeowners

(in 1000s)

All Heating

Fuels $(n=1471)$

Amount Spent

$\$ 0(n=654)$

$\$ 1-\$ 500(n=418)$

$\$ 501-\$ 1000 \quad(n=121)$

$\$ 1001-\$ 2000 \quad(n=118)$

$\$ 2001+(n=160)$

\begin{tabular}{|c|c|c|c|c|}
\hline \multicolumn{5}{|c|}{ Response $(a)$} \\
\hline $\begin{array}{l}\text { Strongly } \\
\text { Disagree }\end{array}$ & Disagree & Neutra? & Agree & $\begin{array}{l}\text { Strongly } \\
\text { Agree }\end{array}$ \\
\hline $6 \%$ & $35 \%$ & $3 \%$ & $43 \%$ & $13 \%$ \\
\hline 5 & 34 & 3 & 46 & 12 \\
\hline 3 & 30 & 3 & 53 & 12 \\
\hline 0 & 18 & 7 & 57 & 19 \\
\hline 2 & 20 & 5 & 65 & 8 \\
\hline
\end{tabular}

(a) In response to the statement, "I consult Consumer Reports or similar publications before making major purchases."

followed closely by those who had spent over $\$ 2,000$. These homeowners probably are or have been the most active group of investors in energy conservation and so would naturally be most familiar with consumer information. Results from the subset of homeowners with electric heat show similar responses to the statement (see Table 8.7.B).

\subsubsection{Attitude Toward utilities Offering Conservation Programs}

All the homeowners tended to disagree with the statement, "Utilities should stop offering a variety of programs to encourage energy conservation." Tabie 8.8. A shows very little difference across the spending levels; between $84 \%$ and $93 \%$ of the spending levels disagreed with the statement. In general, a large majority of the homeowners believed that utilities should continue to offer conservation programs. One point of interest was the fact that $15 \%$ of those who had spent nothing or less than $\$ 500$ agreed with the statement as did $9 \%$ of those who had spent over $\$ 2,000$. This may indicate that some people will not invest in conservation even if a program is offered either because they have already instalied as many ECMs as is practical or because they are not willing to do anything to conserve energy. The responses for the subset of homeowners using electric heat are generally the same. However, some 
TABLE 8.7.B. Amount Homeowners Spent Ouring the Past Two Years to Reduce Energy Use in Their Home, by Attitude Toward Consulting Consumer Reports

Number of Homeowners

\begin{tabular}{|c|c|c|c|c|c|}
\hline $\begin{array}{l}\text { (in 1000s) } \\
\text { Heating Fuel }\end{array}$ & & & ponse ${ }^{(a)}$ & & \\
\hline $\begin{array}{c}\text { Electric }(n=486) \\
\text { Amount Spent }\end{array}$ & $\begin{array}{l}\text { Strongly } \\
\text { Oisagree } \\
\end{array}$ & Disagree & Neutral & Agree & $\begin{array}{l}\text { Strongly } \\
\text { Agree }\end{array}$ \\
\hline$\$ 0(n=241)$ & $0 \%$ & $39 \%$ & $3 \%$ & $48 \%$ & $10 \%$ \\
\hline$\$ 1-\$ 500 \quad(n=155)$ & 6 & 36 & 0 & 48 & 10 \\
\hline$\$ 501-\$ 1000 \quad(n=39)$ & 0 & 34 & 4 & 62 & 0 \\
\hline$\$ 1001-\$ 2000 \quad(n=33)$ & 0 & 17 & 0 & 78 & 5 \\
\hline$\$ 2001+(n=18)$ & 0 & 19 & 0 & 71 & 10 \\
\hline
\end{tabular}

(a) In response to the statement, "I consuit Consumer Reports or similar publications before making major purchases."

TABLE 8.8.A. Amount Homeowners Spent During the Past Two Years to Reduce Energy Use in Their Home, by Attitude Toward Utilities Offering Conservation Programs

Number of Homeowners

(in 1000s)

All Heating

Fuels $(n=1451)$ Amount Spent

$\$ 0(n=642)$

$\$ 1-\$ 500(n=414)$

$\$ 501-\$ 1000 \quad(n=119)$

$\$ 1001-\$ 2000 \quad(n=118)$

$\$ 2001+(n=158)$

\begin{tabular}{|c|c|c|c|c|}
\hline \multicolumn{5}{|c|}{ Response (a) } \\
\hline $\begin{array}{l}\text { Strongly } \\
\text { Oisagree }\end{array}$ & Disagree & Neutral & Agree & $\begin{array}{l}\text { Strongly } \\
\text { Aaree }\end{array}$ \\
\hline $27 \%$ & $57 \%$ & $2 q$ & $12 \%$ & $3 \%$ \\
\hline 21 & 63 & 1 & 14 & 1 \\
\hline 34 & 60 & 0 & 6 & 0 \\
\hline 43 & 50 & 4 & 3 & 0 \\
\hline 32 & 58 & 0 & 7 & 2 \\
\hline
\end{tabular}

(a) In response to the statement, "utilities should stop offering a variety of programs to encourage energy conservation."

noticeable differences appear. A majority of respondents expressed disagreement with the statement, but the range was much wider with between $68 \%$ and $100 \%$ expressing disagreement. For those agreeing with the statement, again the homeowners in the two lowest as well as in the single highest spending levels 
were represented. Between $13 \%$ and $27 \%$ of those who spent nothing or less than $\$ 500$ expressed agreement while $32 \%$ of those who spent over $\$ 2,000$ expressed agreement (see Table 8.8.B).

\subsubsection{Attitude Toward Improving the Efficiency of Their Home}

As siown in Table 8.9.A, over $80 \%$ of all homeowners, regardless of their spending level, disagreed with the statement, "I will invest in improving the efficiency of my home only if there are rebates to me from the utility." From all the spending levels, the three lowest, i.e., spending between $\$ 0$ and $\$ 1,000$, had between $13 \%$ and $17 \%$ expressing agreement with the statement. None of the homeowners who spent between $\$ 1,000$ and $\$ 2,000$ agreed, and on $1 y 6 \%$ of those who spent over $\$ 2,000$ agreed. This $6 \%$ may have already invested as much as they were willing and would require some sort of program to off set the cost of any more ECMs. The responses of the subset of homeowners using electric heat (see Table 8.9.B) are generally the same except that no one in this subset who spent over $\$ 2,000$ expressed agreement with the statement.

\subsubsection{Attitude Toward Electricity Prices in the Northwest}

To determine whether or not the respondents view cost of energy as a motivating factor in conservation, homeowners were asked to respond to,

TABLE 8.8.B. Amount Homeowners Spent Duriag the Past Two Years to Reduce Energy Use in Their Home, by Attitude Toward Utilities offering Conservation Programs

Number of Homeowners

(in 1000s)

Heating Fuel

Electric $(n=478)$

Amount Spent

$50 \quad(n=233)$

$\$ 1-\$ 500 \quad(n=155)$

$\$ 501-\$ 1000 \quad(n=39)$

$\$ 1001-\$ 2000 \quad(n=33)$

$\$ 2001+(n=18)$

\begin{tabular}{lcccc}
\multicolumn{5}{c}{ Response $(a)$} \\
$\frac{\begin{array}{l}\text { Strongly } \\
\text { Disagree }\end{array}}{28 \%}$ & $\frac{\text { Disagree }}{56 \%}$ & $\frac{\text { Neutral }}{4 \%}$ & $\frac{\text { Aoree }}{12 \%}$ & $\begin{array}{c}\text { Strongly } \\
\text { Agree }\end{array}$ \\
16 & 53 & 3 & 26 & $1 \%$ \\
16 & 84 & 0 & 0 & 1 \\
52 & 48 & 0 & 0 & 0 \\
20 & 39 & 0 & 11 & 0
\end{tabular}

(a) In response to the statement, "Utilities should stop offering a variety of programs to encourage energy conservation." 
TABLE 8.9.A. Amount Homeowners Spent During the Past Two Years to Reduce Energy Use in Their Home, by Attitude Toward Improving the Efficiency of Their Home

Number of Homeowners

in 1D00s)

Al) Heating

Fuels $(n=1473)$

Amount Spent

$\$ 0(n=654)$

$\$ 1-\$ 500 \quad(n=415)$

$\$ 501-\$ 1000 \quad(n=121)$

$\$ 1001-\$ 2000 \quad(n=118)$

$\$ 2001+(n=165)$

\begin{tabular}{|c|c|c|c|c|}
\hline \multicolumn{5}{|c|}{ Response (a) } \\
\hline $\begin{array}{l}\text { Strongly } \\
\text { Disagree }\end{array}$ & Disagree & Neutral & Agree & $\begin{array}{l}\text { Strongly } \\
\text { Agree }\end{array}$ \\
\hline $7 \%$ & $76 \%$ & $3 \%$ & $13 \%$ & $0 \%$ \\
\hline 11 & 73 & 2 & 13 & 0 \\
\hline 17 & 66 & 0 & 16 & 1 \\
\hline 10 & 82 & 8 & 0 & 0 \\
\hline 10 & 75 & 8 & 4 & 2 \\
\hline
\end{tabular}

(a) In response to the statement, "I will invest in improving the efficiency of my home oniy if there are rebates to me from the utility."

TABLE 8.9.B. Amount Homeowners Spent During the Past Two Years to Reduce Energy Use in Their Home, by Attitude Toward Improving the Efficiency of Their Home

Number of Homeowners

(in 10005)

Heating Fuel

Electric $(n=480)$

Amount Spent

$\$ 0(n=238)$

$\$ 1-\$ 500 \quad(n=152)$

$\$ 501-\$ 1000 \quad(n=39)$

$\$ 1001-\$ 2000 \quad(n=33)$

$\$ 2001+(n=18)$

\begin{tabular}{|c|c|c|c|c|}
\hline \multicolumn{5}{|c|}{ Response(a) } \\
\hline $\begin{array}{l}\text { Strongly } \\
\text { Oisagree }\end{array}$ & Disagree & NeutraI & Agree & $\begin{array}{l}\text { Strongly } \\
\text { Agree }\end{array}$ \\
\hline $10 \%$ & $73 \%$ & $3 \%$ & $13 \%$ & $1 \%$ \\
\hline 10 & 69 & 2 & 19 & 0 \\
\hline 12 & 76 & 0 & 12 & 0 \\
\hline 0 & 100 & 0 & 0 & 0 \\
\hline 10 & 90 & 0 & 0 & 0 \\
\hline
\end{tabular}

(a) In response to the statement, "I will invest in improving the efficiency of my home only if there are rebates to me from the utility."

"Electricity prices in the Northwest are not high enough to necessitate conservation activities." The assumption might be that those disagreeing with the statement would have spent more on conservation during the past two years. However, this assumption is not supported by the numbers in Table 8.10.A. Over 
TABLE 8.10.A. Amount Homeowners Spent During the Past Two Years to Reduce Energy Use in Their Home, by Attitude Toward Electricity Prices in the Northwest

Number of Homeowners

\begin{tabular}{|c|c|c|c|c|c|}
\hline \multirow{2}{*}{$\begin{array}{r}\text { (in } 1000 s) \\
\text { All Heating } \\
\text { Fuels }(n=1450) \\
\text { Amount Spent }\end{array}$} & \multicolumn{5}{|c|}{ Response (a) } \\
\hline & $\begin{array}{l}\text { Strongly } \\
\text { Disagree }\end{array}$ & Disagree & Neutral & Agree & $\begin{array}{l}\text { Strongly } \\
\text { Agree }\end{array}$ \\
\hline$\$ 0 \quad(n=645)$ & $29 \%$ & $63 \%$ & $1 \%$ & $5 \%$ & $2 \%$ \\
\hline$\$ 1-\$ 500 \quad(n=403)$ & 24 & 69 & 0 & 6 & 1 \\
\hline$\$ 501-\$ 1000 \quad(n=119)$ & 33 & 55 & 4 & 8 & 0 \\
\hline$\$ 1001-\$ 2000 \quad(n=118)$ & 30 & 64 & 3 & 1 & 9 \\
\hline$\$ 2001+(n=165)$ & 33 & 57 & 2 & 8 & 0 \\
\hline
\end{tabular}

(a) In response to the statement, "Electricity Prices in the Northwest Are Not High Enough to Necessitate Conservation Activities."

80\% of all the homeowners disagreed with the statement with differences among the spending levels ranging from $82 \%$ to $94 \%$. The responses from the subset of homeowners using electric heat are similar (see Table 8.10.B). Again over 80\% of these respondents disagreed with the statement including differences among the spending levels ranging from $83 \%$ to $100 \%$.

\subsubsection{Attitude Toward Electricity Rate Changes}

Responses to the statement, "It is silly to conserve electricity because the eiectric utility just turns around and charges more for what you do use," are shown in Table 8.11.A. An assumption might be that homeowners who have actively invested in conservation disagree with this statement. In fact, 79\% of those who spent over $\$ 2,000$ and $72 \%$ of those who spent between $\$ 1,000$ and $\$ 2,000$ did disagree with the statement. No more than $64 \%$ of the respondents in any of the three lower spending levels expressed disagreement with the statement. Conversely, between $32 \%$ and $41 \%$ of the lower and only $26 \%$ of the top two spending groups agreed with the statement. Table 8.11.B contains the responses for the subset of homeowners using electric heat. This group tends to be more 
TABLE B.10.B. Amount Homeowners Spent During the Past Two Years to Reduce Energy Use in Their Home, by Attitude Toward Electricity Prices in the Northwest

Number of Homeowners

\begin{tabular}{|c|c|c|c|c|c|}
\hline $\begin{array}{l}\text { (in 1000s) } \\
\text { Heating Fuel }\end{array}$ & & & ;ponse ${ }^{(a)}$ & & \\
\hline $\begin{array}{c}\text { Electric }(n=468) \\
\text { Amount Spent } \\
\end{array}$ & $\begin{array}{l}\text { Strongly } \\
\text { Disagree }\end{array}$ & Oisagree & Neutral & Agree & $\begin{array}{l}\text { Strongly } \\
\text { Agree } \\
\end{array}$ \\
\hline$\$ 0(n=230)$ & $27 \%$ & $61 \%$ & $3 \%$ & $5 \%$ & $4 \%$ \\
\hline$\$ 1-\$ 500 \quad(n=150)$ & 22 & 73 & 0 & 3 & 1 \\
\hline$\$ 501-\$ 1000 \quad(n=39)$ & 23 & 60 & 12 & 5 & 0 \\
\hline$\$ 1001-\$ 2000 \quad(n=33)$ & 34 & 67 & 0 & 0 & 0 \\
\hline$\$ 2001+(n=18)$ & 10 & 79 & 0 & 11 & 0 \\
\hline
\end{tabular}

(a) In response to the statement, "Electricity Prices in the Northwest Are Not High Enough to Necessitate Conservation Activities."

TABLE 8.11.A. Amount Homeowners Spent Ouring the Past Two Years to Reduce Energy Use in Their Home, by Attitude Toward Electricity Rate Changes Made by the Utility

Number of Homeowners

(in 1000s)

All Heating

Amount Spent

so $(n=655)$

$\$ 1-\$ 500 \quad(n=406)$

$\$ 501-\$ 1000(n=119)$

$\$ 1001-\$ 2000(n=118)$

$\$ 2001+(n=155)$

\begin{tabular}{|c|c|c|c|c|}
\hline \multicolumn{5}{|c|}{ Response(a) } \\
\hline $\begin{array}{l}\text { Strongly } \\
\text { Disagree }\end{array}$ & 0isagree & Neutral & Agree & $\begin{array}{l}\text { Strongly } \\
\text { Agree }\end{array}$ \\
\hline $12 \%$ & $52 \%$ & $4 \%$ & $26 \%$ & $6 \%$ \\
\hline 7 & 49 & 2 & 34 & 7 \\
\hline 19 & 42 & 4 & 35 & 0 \\
\hline 23 & 49 & 2 & 26 & 0 \\
\hline 19 & 60 & 0 & 18 & 3 \\
\hline
\end{tabular}

(a) In response to the statement, "It's silly to conserve electricity because the electric utility just turns around and charges more for what you do use."

cynical in overall responses. Across all the spending levels, more agreement with the statement was evident in the subset than with the entire sample of homeowners. 
TABLE 8.11.B. Amount Homeowners Spent During the Past Two Years to Reduce Energy Use in Their Home, by Attitude Toward Electricity Rate Changes Made by the Utility

Number of Homeowners

(in 1000s)

Heating Fuel

Electric $(n=485)$

Amount Spent

$\$ D(n=242)$

$\$ 1-\$ 500(n=155)$

$\$ 501-\$ 1000 \quad(n=39)$

$\$ 1001-\$ 2000(n=33)$

$\$ 2001+(n=16)$

\begin{tabular}{|c|c|c|c|c|}
\hline \multicolumn{5}{|c|}{ Resoonse $(a)$} \\
\hline $\begin{array}{l}\text { Strongly } \\
\text { Disagree }\end{array}$ & Disagree & Neutral & Agree & $\begin{array}{l}\text { Strong } \\
\text { Agree }\end{array}$ \\
\hline $15 \%$ & $46 \%$ & $2 \%$ & $31 \%$ & $6 \%$ \\
\hline 9 & 45 & 0 & 37 & 9 \\
\hline 5 & 60 & 12 & 23 & 0 \\
\hline 16 & 51 & 0 & 34 & 0 \\
\hline 0 & 78 & 0 & 11 & 11 \\
\hline
\end{tabular}

(a) In response to the statement, "It's silly to conserve electricity because the electric utility just turns around and charges more for what you do use."

\subsubsection{Attitude Toward Power Surplus}

Homeowners who disagreed with the statement, "With the current power surplus in the Northwest there is no need to conserve electricity," might be those who are in the upper spending levels. This expectation is supported by the responses and the distribution of homeowners illustrated in Table 8.12.A. About $30 \%$ of the upper three spending groups (i.e., spending at least $\$ 500$ ) expressed strong disagreement, while the lower spending groups had only $15 \%$ to 17\% expressing strong disagreement. The only homeowners who expressed any strong agreement were those who had spent nothing, and only a small percent of this group did so. The subset of homeowners using electric heat gave similar responses to the statement with more overall disagreement in the top three spending ievels (see Table 8.12.B).

\subsubsection{Attitude Toward the Effect of Conservation Efforts}

Most homeowners disagreed with the statement, "My conservation efforts won't have much effect one way or the other on the avaliability of electricity." The expectation is that those disagreeing would spend more on conservation. The pattern in Table 8.13.A appears to support this expectation. The 
TA8LE 8.12.A. Amount Homeowners Spent During the Past Two Years to Reduce Energy Use in Their Home, by Attitude Toward Power Surplus in the Northwest

Number of Homeowners

(in 1000s)

All Heating

Fue is $(n=1484)$

Amount Spent

$\$ 0(n=662)$

$\$ 1-\$ 500 \quad(n=418)$

$\$ 501-\$ 1000(n=121)$

$\$ 1001-\$ 2000(n=118)$

$\$ 2001+(n=165)$

\begin{tabular}{|c|c|c|c|c|}
\hline \multicolumn{5}{|c|}{ Response ${ }^{(a)}$} \\
\hline $\begin{array}{l}\text { Strongly } \\
\text { Disagree }\end{array}$ & Disagree & Neutral & Agree & $\begin{array}{l}\text { Strongly } \\
\text { Agree }\end{array}$ \\
\hline $15 \%$ & $80 \%$ & $1 \%$ & $3 \%$ & $2 \%$ \\
\hline 17 & 78 & 1 & 4 & 0 \\
\hline 34 & 59 & 0 & 7 & 0 \\
\hline 28 & 69 & 0 & 3 & 0 \\
\hline 29 & 63 & 0 & 8 & 0 \\
\hline
\end{tabular}

(a) In response to the statement, "With the current power surplus in the Northwest, there is no need to conserve electricity."

TABLE 8.12.B. Amount Homeowners Spent During the Past Two Years to Reduce Energy Use in Their Home, by Attitude Toward Power Surplus in the Northwest

Number of Homeowners

(in 1000s)

Heating Fuel

Electric $(n=490)$ Amount Spent

$\$ 0(n=247)$

$\$ 1-\$ 500 \quad(n=155)$

$\$ 501-\$ 1000 \quad(n=39)$

$\$ 1001-\$ 2000 \quad(n=33)$

$\$ 2001+(n=16)$

\begin{tabular}{ccccc}
\multicolumn{5}{c}{ Response $(\mathrm{a})$} \\
$\begin{array}{c}\text { Strongly } \\
\text { Disagree }\end{array}$ & Disagree & $\frac{\text { Neutral }}{15 \%}$ & $\frac{\text { Agree }}{3 \%}$ & $\begin{array}{c}\text { Strongly } \\
\text { Agree }\end{array}$ \\
\cline { 2 - 3 } & $76 \%$ & 0 & $4 \%$ & $3 \%$ \\
12 & 76 & 0 & 6 & 0 \\
21 & 83 & 0 & 0 & 0 \\
0 & 79 & 0 & 0 & 0
\end{tabular}

(a) In response to the statement, "With the current power surplus in the Northwest, there is no need to conserve electricity."

percentages of those disagreeing with the statement increased as the level of spending increased. For example, 69\% of those who had spent nothing disagreed with it, while $84 \%$ of those who had spent over $\$ 2,000$ disagreed with it. The pattern is further jllustrated in the distribution of homeowners who agreed 
TABLE 8.13.A. Amount Homeowners Spent During the Past Two Years to Reduce Energy Use in Their Home, by Attitude Toward the Effect of Conservation Efforts

Number of Homeowners

\begin{tabular}{|c|c|c|c|c|c|}
\hline \multirow{2}{*}{$\begin{array}{r}\text { (in 1000s) } \\
\text { AIl Heating } \\
\text { Fuels ( } n=1455) \\
\text { Amount Spent }\end{array}$} & \multicolumn{5}{|c|}{ Response $^{(a)}$} \\
\hline & $\begin{array}{l}\text { Strongly } \\
\text { Disagree }\end{array}$ & Disagree & Neutral & Agree & $\begin{array}{l}\text { Strongly } \\
\text { Agree }\end{array}$ \\
\hline$\$ 0 \quad(n=640)$ & $10 \%$ & $59 \%$ & $2 \%$ & $28 \%$ & $1 \%$ \\
\hline$\$ 1-\$ 500 \quad(n=415)$ & 9 & 68 & 2 & 19 & 2 \\
\hline$\$ 501-\$ 1000 \quad(n=121)$ & 13 & 67 & 1 & 14 & 4 \\
\hline$\$ 1001-\$ 2000 \quad(n=116)$ & 18 & 63 & 4 & 15 & 0 \\
\hline$\$ 2001+(n=163)$ & 20 & 64 & 2 & 12 & 2 \\
\hline
\end{tabular}

(a) In response to the statement, "My conservation efforts won't have much effect one way or the other on the availability of electricity."

with the statement. Nearly 29\% of the "no spenders" agreed, while 14\% of the highest spending level agreed. The response pattern of the subset of homeowners using electric heat is shown in Table 8.13.B and is similar to that of the entire sample of homeowners.

TABLE 8.13.B. Amount Homeowners Spent During the Past Two Years to Reduce Energy Use in Their Home, by Attitude Toward the Effect of Conservation Efforts

\begin{tabular}{|c|c|c|c|c|c|}
\hline \multirow{2}{*}{$\begin{array}{c}\text { Number of Homeowners } \\
\text { (in 1000s) } \\
\text { Heating Fue } \\
\text { Electric (n=476) } \\
\text { Anount Soent } \\
\end{array}$} & \multicolumn{5}{|c|}{ Response ${ }^{(a)}$} \\
\hline & $\begin{array}{l}\text { Strongly } \\
\text { Disagree }\end{array}$ & Disagree & Neutral & Agree & $\begin{array}{l}\text { Strongiy } \\
\text { Aoree }\end{array}$ \\
\hline$\$ 0 \quad(n=234)$ & $9 \%$ & $56 \%$ & $2 \%$ & $32 \%$ & $2 \%$ \\
\hline$\$ 1-\$ 500 \quad(n=152)$ & 9 & 65 & 0 & 26 & 0 \\
\hline$\$ 501-\$ 1000 \quad(n=39)$ & 12 & 75 & 0 & 13 & 0 \\
\hline$\$ 1601-\$ 2000 \quad(n=33)$ & 11 & 75 & 0 & 14 & 0 \\
\hline$\$ 2001+(n=18)$ & 0 & 79 & 10 & 11 & 0 \\
\hline
\end{tabular}

(a) In response to the statement, "My conservation efforts won't have much effect one way or the other on the availability of electricity." 


\subsubsection{Attitude Toward Protecting the Environment}

The statement, "Conserving energy is the best way to protect the environment," attempts to determine if the homeowner is somewhat "altruistic." Between $69 \%$ and $75 \%$ of homeowners regardless of spending level agreed with the statement (see Table 8.14.A). Homeowner agreement and disagreement with the statement are evenly distributed over the spending leveis. Between $18 \%$ and $25 \%$ of all the spending groups said they disagreed with the statement, and oniy the two lowest spending groups expressed strong disagreement. The responses of the subset of homeowners using electric heat are found in Table 8.14.8 and are similar to those of the entire sample of homeowners, except for those who spent between $\$ 500$ to $\$ 1,000$. This group did not have anyone expressing ejther strong disagreement or strong agreement with the statement, and $16 \%$ gave a neutral response.

\subsubsection{Attitude Toward Conserving Electricity for Future Generations}

The statement, "It is our responsibility to conserve electricity for future generations," is similar to the previous one in that it has an altruistic, socially responsible tone. Again, a vast majority of the homeowners

TABLE 8.14.A. Amount Homeowners Spent During the Past Two Years to Reduce Energy Use in Their Home, by Attitude Toward Protecting the Environment

Number of Homeowners

\begin{tabular}{|c|c|c|c|c|c|}
\hline \multirow{2}{*}{$\begin{array}{r}(\text { in 1000s) } \\
\text { All Heating } \\
\text { Fuels (n=1410) } \\
\text { Amount Spent } \\
\end{array}$} & \multicolumn{5}{|c|}{ Response $(a)$} \\
\hline & $\begin{array}{l}\text { Strongly } \\
\text { Disagree }\end{array}$ & Disagree & Neutral & Aoree & $\begin{array}{l}\text { Strongly } \\
\text { Agree }\end{array}$ \\
\hline$\$ 0 \quad(n=622)$ & $1 \%$ & $20 \%$ & $8 \%$ & $64 \%$ & $8 \%$ \\
\hline$\$ 1-\$ 500 \quad(n=393)$ & 2 & 21 & 4 & 60 & 13 \\
\hline$\$ 501-\$ 1000 \quad(n=121)$ & 0 & 18 & 9 & 64 & 10 \\
\hline$\$ 1001-\$ 2000 \quad(n=116)$ & 0 & 25 & 6 & 59 & 10 \\
\hline$\$ 2001+(n=158)$ & 0 & 19 & 4 & 67 & 9 \\
\hline
\end{tabular}

(a) In response to the statement, "Conserving energy is the best way to protect the environment." 
TABLE 8.14.B. Amount Homeowners Spent During the Past Two Years to Reduce Energy Use in Their Home, by Attjtude Toward Protecting the Environment

Number of Homeowners

(in 1000s)

Heating Fuel

Electric $(n=469)$

Amount Spent

$\$ 0(n=233)$

$\$ 1-\$ 500 \quad(n=148)$

$\$ 501-\$ 1000(n=39)$

$\$ 1001-\$ 2000 \quad(n=33)$

$\$ 2001+(n=16)$

\begin{tabular}{|c|c|c|c|c|}
\hline \multicolumn{5}{|c|}{ Response ${ }^{(a)}$} \\
\hline $\begin{array}{l}\text { Strongly } \\
\text { Disagree }\end{array}$ & Disagree & Neutra? & Agree & $\begin{array}{l}\text { Strongly } \\
\text { Agree }\end{array}$ \\
\hline $0 \%$ & $23 \%$ & $8 \%$ & $60 \%$ & $9 \%$ \\
\hline 0 & 25 & 1 & 64 & 10 \\
\hline 0 & 34 & 16 & 49 & 0 \\
\hline 0 & 19 & 6 & 64 & 11 \\
\hline 0 & 30 & 0 & 57 & 13 \\
\hline
\end{tabular}

(a) In response to the statement, "Conserving energy is the best way to protect the environment."

expressed agreement. As shown in Table 8.15.A, between $82 \%$ and $90 \%$ of the homeowners agreed with the statement, regardless of spending level. A similar response pattern is seen in Table 8.15 .B for the subset of homeowners using electric heat.

TABLE 8.15.A. Amount Homeowners Spent During the Past Two Years to Reduce Energy Use in Their Home, by Attitude Toward Conserving Electricity for Future Generations

Number of Homeowners

\begin{tabular}{|c|c|c|c|c|c|}
\hline \multirow{2}{*}{$\begin{array}{r}\text { (in 1000s) } \\
\text { AI Heating } \\
\text { Fuels ( } n=1456) \\
\text { Amount Spent } \\
\end{array}$} & \multicolumn{5}{|c|}{ Response $^{(a)}$} \\
\hline & $\begin{array}{l}\text { Strongly } \\
\text { Disagree }\end{array}$ & Disagree & Neutral & Agree & $\begin{array}{l}\text { Strongly } \\
\text { Agree }\end{array}$ \\
\hline $50 \quad(n=646)$ & $1 \%$ & $12 \%$ & $3 \%$ & $72 \%$ & $11 \%$ \\
\hline$\$ 1-\$ 500 \quad(n=415)$ & 2 & 9 & 4 & 72 & 13 \\
\hline$\$ 501-\$ 1000 \quad(n=119)$ & 0 & 15 & 1 & 51 & 32 \\
\hline$\$ 1001-\$ 2000 \quad(n=118)$ & 0 & 18 & 0 & 58 & 24 \\
\hline$\$ 2001+(n=158)$ & 3 & 3 & 3 & 74 & 16 \\
\hline
\end{tabular}

(a) In response to the statement, "It's our responsibility to conserve electricity for future generations." 
TABLE 8.15.8. Amount Homeowners Spent During the Past Two Years to Reduce Energy Use in Their Home, by Att itude Toward Conserving Electricity for Future Generations

Number of Homeowners

(in 1000s)

Heating Fuel

Electric $(n=480)$

Amount Spent

$\$ 0(n=237)$

$\$ 1-\$ 500(n=155)$

$\$ 501-\$ 1000 \quad(n=37)$

$\$ 1001-\$ 2000(n=33)$

$\$ 2001+(n=18)$

\begin{tabular}{|c|c|c|c|c|}
\hline \multicolumn{5}{|c|}{ Response(a) } \\
\hline $\begin{array}{l}\text { Strongiy } \\
\text { Disagree }\end{array}$ & Disagree & Neutral & Agree & $\begin{array}{l}\text { Strongly } \\
\text { Agree }\end{array}$ \\
\hline $0 \%$ & $11 \%$ & $3 \%$ & $72 \%$ & $14 \%$ \\
\hline 0 & 9 & 0 & 74 & 16 \\
\hline 0 & 9 & 5 & 62 & 25 \\
\hline 0 & 5 & 0 & 64 & 31 \\
\hline 11 & 0 & 0 & 89 & 0 \\
\hline
\end{tabular}

(a) In response to the statement, "It's our responsibility to conserve electricity for future generations."

\subsubsection{Attitude Toward Conserving Electricity to Save Money}

"Most people who conserve electricity do so to save money," is a statement designed to determine whether or not saving money motivates homeowmers to conserve energy. At least $90 \%$ of all homeowners expressed agreement (see Table 8.16.A). The one difference across spending levels was slight but interesting. A small percentage of the high spenders were the only homeowners to strongly disagree, which indicates that they may have invested for other reasons. They also had the smallest majority expressing agreement. The subset of homeowners using electric heat gave a weaker response which was similar to that given by the entire set of homeowners. As illustrated in Table 8.16.B, at least $80 \%$ of all homeowners expressed agreement.

\subsubsection{Attitude Toward Conservation Improving Value of Their Home}

As Table 8.17.A. illustrates, the majority of the homeowners disagreed with the statemert, "I would only make conservation improvements which would enhance the value of my home." Over $74 \%$ of those who had spent something on conservation expressed disagreement, while only 66: of those who had spent nothing also disagreed. Interestingly, $4 \%$ of those who spent over $\$ 2,000$ strongly agreed with the statement, which suggests that after a certain point 
TABLE 8.16.A. Amount Homeowners Spent During the Past Two Years to Reduce Energy Use in Their Home, by Attitude Toward Conserving Electricity to Save Money

Number of Homeowners

(in 1000s)

All Heating

Fuels $(n=1485)$

Amount Spent

$\$ 0(n=665)$

$\$ 1-\$ 500 \quad(n=418)$

$\$ 501-\$ 1000(n=121)$

$\$ 1001-\$ 2000(n=118)$

$\$ 2001+(n=163)$

\begin{tabular}{|c|c|c|c|c|}
\hline \multicolumn{5}{|c|}{ Response $^{(a)}$} \\
\hline $\begin{array}{l}\text { Strongly } \\
\text { Disagree }\end{array}$ & Disagree & Neutral & Agree & $\begin{array}{c}\text { Strongly } \\
\text { Agree }\end{array}$ \\
\hline $0 \%$ & $4 \%$ & $2 \%$ & $80 \%$ & $14 \%$ \\
\hline 0 & 7 & 2 & 81 & 11 \\
\hline 0 & 4 & 0 & 71 & 25 \\
\hline 0 & 6 & 0 & 78 & 16 \\
\hline 1 & 9 & 0 & 73 & 17 \\
\hline
\end{tabular}
(a) In response to the statement, "Most people who conserve electricity do so
to save money."

TABLE 8.16.B. Amount Homeowners Spent During the Past Two Years to Reduce Energy Use in Their Home, by Attitude Toward Conserving Electricity to Save Money

Number of Homeowners

\begin{tabular}{|c|c|c|c|c|c|}
\hline \multirow{2}{*}{$\begin{array}{c}\text { (in 1000s) } \\
\text { Heating Fue? } \\
\text { Electric }(n=492) \\
\text { Amount Spent }\end{array}$} & \multicolumn{5}{|c|}{ Response ${ }^{(a)}$} \\
\hline & $\begin{array}{l}\text { Strongly } \\
\text { Disagree }\end{array}$ & Disagree & Neutral & Aaree & $\begin{array}{l}\text { Strongly } \\
\text { Agree }\end{array}$ \\
\hline$\$ 0 \quad(n=247)$ & $0 \%$ & $3 \%$ & $3 \%$ & $80 \%$ & $14 \%$ \\
\hline$\$ 1-\$ 500 \quad(n=155)$ & 0 & 12 & 1 & 79 & 8 \\
\hline$\$ 501-\$ 1000 \quad(n=39)$ & 0 & 0 & 0 & 74 & 26 \\
\hline$\$ 1001-\$ 2000 \quad(n=33)$ & 0 & 0 & 0 & 88 & 12 \\
\hline$\$ 2001+(n=18)$ & 10 & 10 & 0 & 69 & 11 \\
\hline
\end{tabular}

(a) In response to the statement, "Most people who conserve electricity do so to save money."

functional conservation is saturated; and other motivating factors must be used to induce further investment. The subset of homeowners using electric heat tends to agree with the statement more often, especially at the higher spending levels (i.e., \$1,000+) (see Table 8.17.B). 
TABLE 8.17.A. Amount Homeowners Spent During the Past Two Years to Reduce Energy Use in Their Home, by Attitude Toward Conservation Improving Values of Their Home

\begin{tabular}{|c|c|c|c|c|c|}
\hline $\begin{array}{c}\text { Number of Homeowners } \\
\text { (in loo0s) } \\
\text { All Heating }\end{array}$ & & & sponse ${ }^{(a)}$ & & \\
\hline $\begin{array}{l}\text { Fuels }(n=1476) \\
\text { Amount Spent }\end{array}$ & $\begin{array}{l}\text { Strongly } \\
\text { Disagree }\end{array}$ & Disagree & Neutral & Agree & $\begin{array}{l}\text { Strongly } \\
\text { Agree }\end{array}$ \\
\hline \$O $(n=654)$ & $4 \%$ & $62 \%$ & $5 \%$ & $26 \%$ & $2 \%$ \\
\hline$\$ 1-\$ 500 \quad(n=418)$ & 6 & 68 & 3 & 21 & 2 \\
\hline$\$ 501-\$ 1000 \quad(n=121)$ & 15 & 67 & 0 & 18 & 0 \\
\hline$\$ 1001-\$ 2000 \quad(n=118)$ & 0 & 87 & 0 & 11 & 2 \\
\hline$\$ 2001+(n=165)$ & 1 & 74 & 5 & 16 & 4 \\
\hline
\end{tabular}

(a) In response to the statement, "I would only make conservation improvements which would enhance the value of my home."

TABLE 8.17.8. Amount Homeowners Spent During the Past Two Years to Reduce Energy Use in Their Home, by Attitude Toward Conservation lmproving Values of Their Home

Number of Homeowners

\begin{tabular}{|c|c|c|c|c|c|}
\hline \multirow{2}{*}{$\begin{array}{l}\text { (in 1000s) } \\
\text { Heating Fuet } \\
\text { Electric }(n=481) \\
\text { Amount Spent }\end{array}$} & \multicolumn{5}{|c|}{ Response ${ }^{(a)}$} \\
\hline & $\begin{array}{l}\text { Strongly } \\
\text { Disagree } \\
\end{array}$ & Dísagree & Neutral & Agree & $\begin{array}{l}\text { Strongly } \\
\text { Agree }\end{array}$ \\
\hline$\$ 0 \quad(n=236)$ & $3 \%$ & $67^{\circ}$ & $5 \%$ & $22 \%$ & $3 \%$ \\
\hline$\$ 1-\$ 500 \quad(n=155)$ & 7 & 71 & 0 & 20 & 2 \\
\hline$\$ 501-\$ 1000 \quad(n=39)$ & 0 & 88 & 0 & 12 & 0 \\
\hline$\$ 1001-\$ 2000 \quad(n=33)$ & 0 & 70 & 0 & 24 & 6 \\
\hline$\$ 2001+(n=18)$ & 0 & 61 & 10 & 29 & 0 \\
\hline
\end{tabular}
(a) In response to the statement, "1 would only make conservation improvements which would enhance the value of my home."

\subsubsection{Attitude Toward Conservation Increasing the Comfort of the Home \\ "I would invest in energy conservation measures because it increases the} comfort of my home." The purpose of this attitudinal statement is to determine 
whether comfort is a motivating factor in the conservation investment decision. The numbers in Table 8.18.A indicate that approximately $90 \%$ of the homeowners agree with the statement. Over $20 \%$ of those who had spent over $\$ 2,000$

TABLE 8.18.A. Amount Homeowners Spent During the Past Two Years to Reduce Energy Use in Their Home, by Attitude Toward Increasing Comfort of Their Home

Number of Homeowners

\begin{tabular}{|c|c|c|c|c|c|}
\hline $\begin{array}{l}\text { (in 1000s) } \\
\text { All Heating }\end{array}$ & & & ponse ${ }^{(a}$ & & \\
\hline $\begin{array}{l}\text { Fuels ( } n=1471) \\
\text { Amount Spent }\end{array}$ & $\begin{array}{l}\text { Strongly } \\
\text { Oisagree }\end{array}$ & Oisagree & Neutral & Agree & $\begin{array}{l}\text { Strongly } \\
\text { Agree }\end{array}$ \\
\hline$\$ 0 \quad(n=649)$ & $1 \%$ & $6 \%$ & $1 \%$ & $85^{\circ}$ & $7 \%$ \\
\hline$\$ 1-\$ 500 \quad(n=418)$ & 1 & 5 & 1 & 84 & 9 \\
\hline$\$ 501-\$ 1000 \quad(n=121)$ & 4 & 3 & 1 & 72 & 20 \\
\hline$\$ 1001-\$ 2000 \quad(n=118)$ & 0 & 5 & 0 & 86 & 9 \\
\hline$\$ 2001+(n=165)$ & 0 & 5 & 1 & 73 & 21 \\
\hline
\end{tabular}

(a) In response to the statement, "I would invest in energy conservation measures because it increases the comfort of my home."

TABLE 8.18.8. Amount Homeowners Spent During the Past Two Years to Reduce Energy Use in Their Home, by Attitude Toward Increasing Comfort of Their Home

Number of Homeowners

\begin{tabular}{|c|c|c|c|c|c|}
\hline \multirow{2}{*}{$\begin{array}{l}\text { (in 1000s) } \\
\text { Heating Fuel } \\
\text { Electric }(n=483) \\
\text { Amount Soent }\end{array}$} & \multicolumn{5}{|c|}{ Response (a) } \\
\hline & $\begin{array}{l}\text { Strongly } \\
\text { Di sagree }\end{array}$ & Disagree & Neutral & Agree & $\begin{array}{l}\text { Strongly } \\
\text { Agree }\end{array}$ \\
\hline$\$ 0 \quad(n=238)$ & $1 \%$ & $6 \%$ & $2 \%$ & $90 \%$ & $2 \%$ \\
\hline$\$ 1-\$ 500 \quad(n=155)$ & 0 & 3 & 0 & 93 & 4 \\
\hline$\$ 501-\$ 1000 \quad(n=39)$ & 0 & 0 & 4 & 79 & 16 \\
\hline$\$ 1001-\$ 2000 \quad(n=33)$ & 0 & 0 & 0 & 88 & 12 \\
\hline$\$ 2001+(n=18)$ & 0 & 0 & 0 & 89 & 11 \\
\hline
\end{tabular}

(a) In response to the statement, "I would invest in energy conservation measures because it increases the comfort of my home." 
in the last two years expressed strong agreement with the statement. Comfort appears to be the second major motivator following monetary savings, especially for those who have achieved the highest spending level. The subset of homeowners using electric heat have a similar distribution of responses, however, they were less likely to strongly agree with the statement (see Table 8.18.B).

\subsection{SUMMARY OF FINOINGS IN THE CHAPTER}

The first section of Chapter 8.0 looked at the influence homeowners' perceptions had on spending for energy conservation. Three specific issues were addressed, homeowners concern for energy use in the home, cost of energy, and energy conservation. In general, as concern for an issue increased so did the level of conservation spending. Of the three issues, homeowners expressed greatest concern over the cost of energy, this was also the case for the subset of homeowners using electric heat. Generally, the subset of homeowners using electric heat mirrored the whole set of homeowners with regard to responses.

However, they differed from the complete set of homeowners in the area of spending behavior. Generally those homeowners with electric heat tended to spend less on energy conservation than did the entire sample. The general distribution across spending levels is as follows: approximately $50 \%$ of the electric subset spent nothing, $45 \%$ of the full set spent nothing, and only ibout $4 \%$ of the subset spent over $\$ 2,000$ while $11 \%$ of the entire sampie spent over $\$ 2,000$.

In the second section of Chapter 8.0 , a series of 15 attitudinal statements were reviewed. It became apparent that those who spent nothing were more likely to give a negative response to the statements while those who spent something on energy conservation tended to give more positive responses. For example, those who had spent nothing tended to agree more often that their energy use was no ones' business but their own, and that investments to improve efficiency would occur only if a rebate program existed at the utility.

An interesting observation involving a small percentage of those who had achieved the upper spending levels might seem to contradict the general trend mentioned above. For several statements there were homeowners from the high spending levels who gave negative responses. For example, about $15 \%$ of the 
lower spending groups and about $9 \%$ of the highest spending group felt that the utilities should eliminate conservation programs. In another instance, none of those who spent between $\$ 1,000$ and $\$ 2,000$ agreed that future investment would occur only if a rebate were available from the utility. However, $6 \%$ of those who spent over $\$ 2,000$ did state that that would be the case. The assumption from these two examples might be that a portion of those who spent around $\$ 2,000$ may have invested as much as was practical or as much as they were willing to invest.

The hypothesis which was tested in this chapter states, that the amount of money spent on ECMs will not vary by homeowners' perceptions of conservation. The findings indicate that the hypothesis should be rejected, for instance in the first section of the chapter it was revealed that homeowners who were more concerned about energy related issues tend to spend more on energy conservation than those who are not as concerned. The results in the second section also support rejection of the hypothesis because homeowner's attitudes were shown to have either positive or negative impact on conservation spending. 


\subsection{BARR IERS TO ENERGY CONSERVATION INVESTMENT}

The purpose of this chapter is to provide insight into the primary barriers to conservation investment, according to the opinions of the interviewed homeowners. One way to assess this issue is to classify the barriers as economic and noneconomic. In this chapter, we will discuss responses to questions which test the hypothesis that the primary barriers to homeowner investment in ECMs are noneconomic.

\subsection{REASONS NOT TO INVEST IN CONSERVATION MEASURES}

Reasons not to invest in energy conservation measures, as expressed by the entire sample of homeowners and by those househoids using electricity, are shown in Figures 9.1.A and 9.1.B. Nearly $60 \%$ of the homeowners stated that cost was the primary barrier to conservation investment. The next most frequent reason given for not investing was that homeowners felt no need to invest. This may be true for some of the residences. However, a relatively large segment of these homeowners may not be aware that certain ECMs can reduce energy use and still be cost effective.

For homeowners in the entire sample and in households using electricity, the reasons given for not investing in ECMs do not appear to differ by the level of total household income (see Tables 9.1.A and 9.1.B). However, the reasons may be influenced by the length of time respondents had lived at their current residences, particularly for the entire sample group (see Tables 9.2.A and 9.2.B). Over $70 \%$ of the entire sample's respondents who had 1 ived at their current residences for two years or less stated that cost was the primary reason not to invest, whereas less than $60 \%$ of respondents in the entire sample who lived at their residences for three years or longer offered cost as the primary reason not to invest. Homeowners from the entire sample who had lived at their current residences three years or longer stated more often that they did not need to install any conservation measures. These results may indicate that if homeowners are going to invest in ECMS, they may be more inclined to do so during the first couple of years in their residences. A similar observation 
can be made for households using electricity. Overall, homeowners were more inclined to state that they did not need to install any conservation measures than to give cost as a reason for not investing.

A breakdown between the type of residences the homeowners were currently living in and their respective reasons for nct investing in ECMs is shown for the entire sample and households using electricity in Tables 9.3.A and 9.3.8. Homeowners in single-family detached homes most frequentiy mentioned cost as the reason not to invest in ECMs $161 \%$ from the entire sample, $60 \%$ from households using electricity) followed by don't need (25\% from the entire sample, $27 \%$ from households using electricity).

An interesting result appears when the amount homeowners spent during the past two years to reduce energy use is broken down by the reasons for not investing in ECMs (see Tabies 9.4.A and 9.4.B). Cost was the most frequently mentioned reason for not investing according to each of the homeowners from their past spending levels. However, $30 \%$ of the entire sample and $34 \%$ of the households using electricity spent nothing during the past two years to reduce energy use and reported that they did not need to invest in ECMs; and $30 \%$ of the entire sample and $23 \%$ of the households using electricity spent $\$ 2000$ or more during tine past two years and reported that they did not need to invest in ECMs. To better understand those respondents who had spent no money on ECMs, it may be necessary to further analyze why they felt no need to do so.

\subsection{SUMMARY}

The results presented in this chapter overwhelsingly show that, according to the reports from respondents, the primary barriers to investment in EcMs are economic. The hypothesis in question states just the opposite and can therefore be rejected. Homeowners reporting cost as a barrier may be unaware of utility sponsored conservation programs or other types of loan programs that couid aid in reducing costs and/or make investing in ECMs financialiy appealing. Another important area for further exploration is the question of why $30_{\%}^{*}$ of homeowners feel that there is no need to invest in ECMs. 


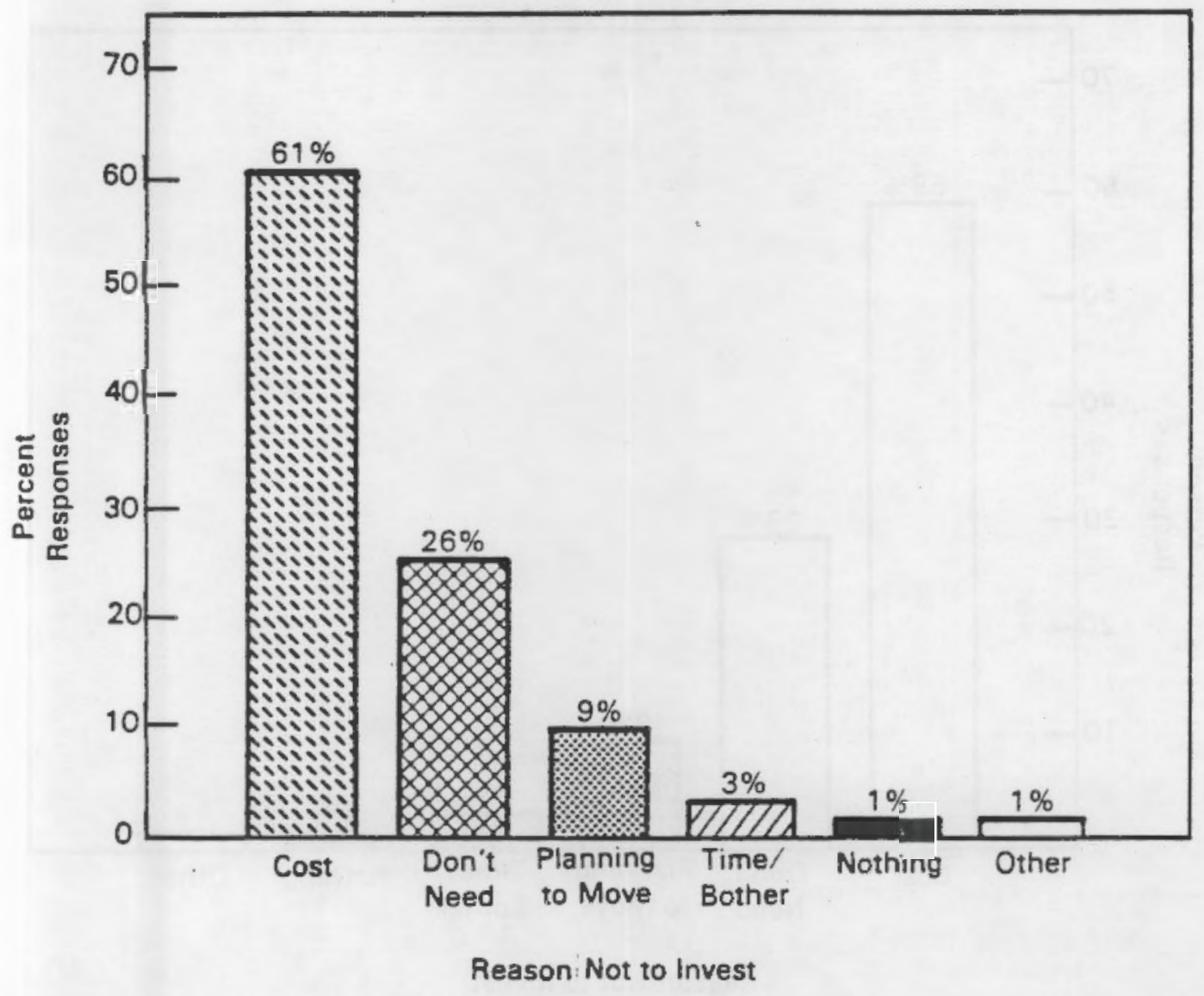

FIGURE 9.1.A. Reasons For Not Investing In Energy Conservation Measures, Heating Fuel Electric 


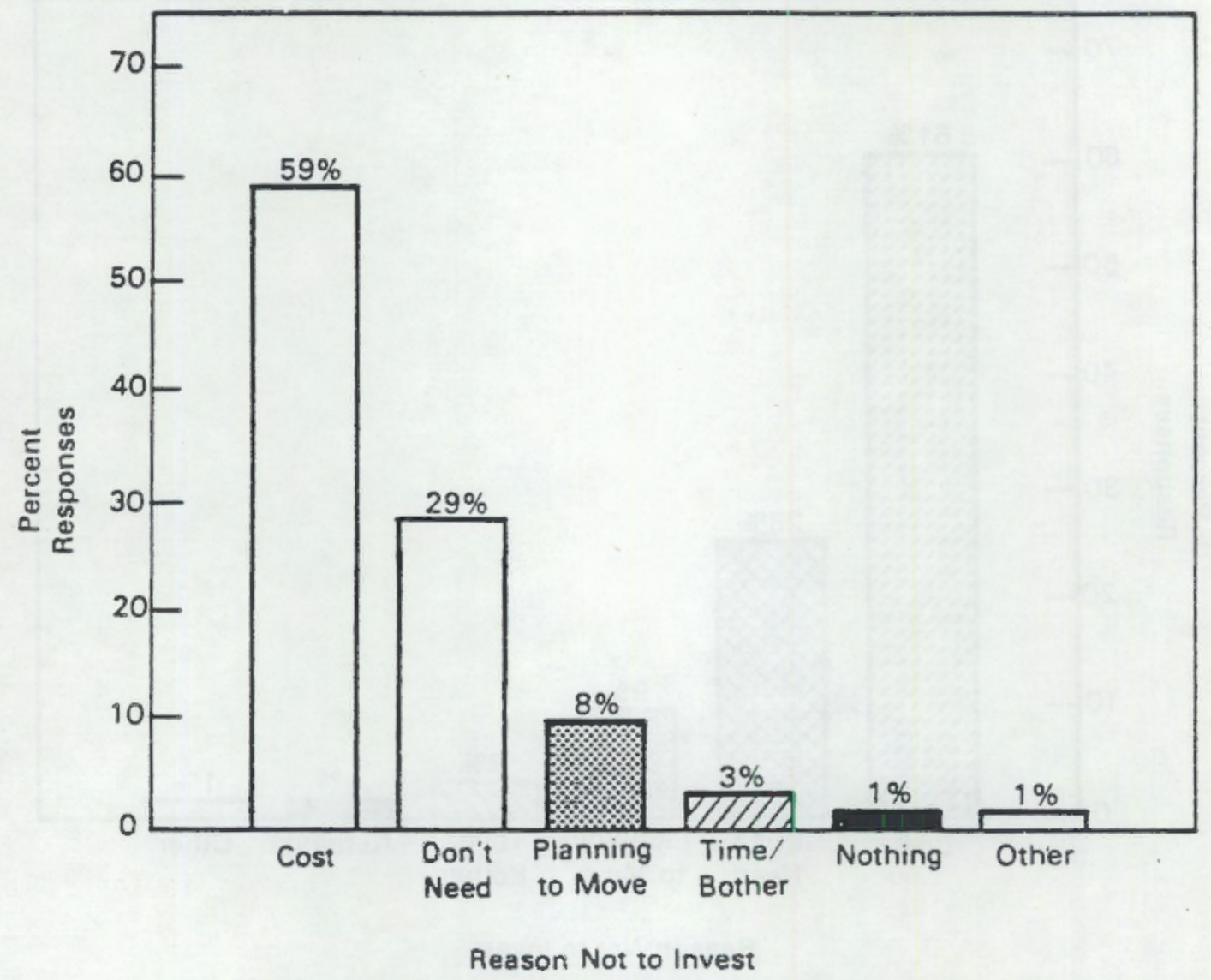

FIGURE 9.1.8. Reasons For Not Investing In Energy Conservation Measures, All Heating Fuels 
TABLE 9.1.A. Reason Not to Invest in Energy Conservation Measures, by Total Household Income

\begin{tabular}{|c|c|c|c|c|c|c|}
\hline \multirow{2}{*}{$\begin{array}{l}\text { Number of Respondents } \\
\text { (in 1000s) A1\} Heating } \\
\text { Fuels ( }=1744 \text { ) Total } \\
\text { Household Income }\end{array}$} & \multicolumn{6}{|c|}{ Reason Not to Invest } \\
\hline & Cost & $\begin{array}{l}\text { Don't } \\
\text { Need }\end{array}$ & $\begin{array}{l}\text { Planning } \\
\text { to Move } \\
\end{array}$ & $\begin{array}{l}\text { Time/ } \\
\text { Bother- }\end{array}$ & None & Other \\
\hline$<\$ 16,000 \quad(n=380)$ & $60 \%$ & $26 \%$ & $9 \%$ & $2 \%$ & $1 \%$ & $2 \%$ \\
\hline$\$ 16,000-\$ 30,000 \quad(n=651)$ & 62 & 24 & 9 & 5 & 0 & 0 \\
\hline$\$ 30,000+(n=713)$ & 61 & 27 & 7 & 3 & 1 & 0 \\
\hline
\end{tabular}

TABLE 9.1.B. Reason Not to Invest in Energy Conservation Measures, by Total Household Income

Number of Respondents

(in 1000s) Heating

Fuel Electric $(n=992)$

Total Household Income

$<\$ 16,000(n=238)$

$\$ 16,000-\$ 30,000 \quad(n=375)$

$\$ 30,000+(n=379)$

\begin{tabular}{|c|c|c|c|c|c|}
\hline & $\operatorname{Don}^{\prime} t$ & Panning & Time/ & & \\
\hline Cost & Need & to Move & Bother & None & Other \\
\hline $59 \%$ & $29 \%$ & $8 \%$ & $1 \%$ & $1 \%$ & $2 \%$ \\
\hline 62 & 25 & 7 & 5 & 1 & 1 \\
\hline 58 & 31 & 7 & 3 & 2 & 0 \\
\hline
\end{tabular}

TABLE 9.2.A. Reason Not to Invest in Energy Conservation Measures, by Length of Time Homeowners Have Been at Their Residence

Number of Homeowners

(in 1000s)

All Heating Fuels $(n=1890)$

Length of Time

at Residence

$<1$ Year $(n=237)$

$1-2$ Years $(n=130)$

3-4 Years $(n=223)$

$5+$ Years $(n=1300)$

\begin{tabular}{|c|c|c|c|c|c|}
\hline $\cos t$ & $\begin{array}{l}\text { Don't } \\
\text { Need } \\
\end{array}$ & $\begin{array}{l}\text { PTanning } \\
\text { to Move }\end{array}$ & $\begin{array}{l}\text { Time/ } \\
\text { Bother }\end{array}$ & None & Other \\
\hline $74 \%$ & $14 \%$ & $9 \%$ & $2 \%$ & $1 \%$ & $1 \%$ \\
\hline 71 & 15 & 11 & 4 & 0 & 0 \\
\hline 59 & 25 & 11 & 2 & 1 & 1 \\
\hline 57 & 29 & 9 & 3 & 1 & 1 \\
\hline
\end{tabular}


TABLE 9.2.8. Reason Not to Invest in Energy Conservation Measures, by Length of Time Homeowners Have Been at Their Residence

Number of Homeawners

(in 1000s) Heating

Fuel Electric $(n=1071)$ Length of Time

Reason Not to Invest

\begin{tabular}{c} 
Length of rime \\
at Residence \\
\hline
\end{tabular}

$<1$ Year $(n=164)$ $\frac{\text { Cost }}{68 \%} \frac{\text { Need }}{17 \%} \frac{\text { to Move }}{11 \%} \frac{\text { Bother }}{3 \%} \frac{\text { None }}{1 \%} \frac{\text { Other }}{0 \%}$

$1-2$ Years $(n=70)$

$67 \quad 25$

3-4 Years $(n=131)$

$60 \quad 26$

5 + Years $(n=706)$

$56 \quad 32$

8

8

0

$0 \quad 0$

6

2

3

$0 \quad 2$

TABLE 9.3.A. Reason Not to Invest in Energy Conservation Measures, by Type of Residence

Number of Homeowners

(in 1000s) Al?

Heating Fuels ( $n=1892$ )

Types of Residence

Single Family Detached

Home $(n=1662)$

2-4 FamiTy Home-Duplex-

Townhouse $(n=33)$

Building with More than

4 Units $(n=11)$

Mobile Home/Trailer

$53 \quad 35$

Reason Not to Invest

\begin{tabular}{|c|c|c|c|c|c|}
\hline $\cos t$ & $\begin{array}{l}\text { Don't } t \\
\text { Need }\end{array}$ & $\begin{array}{l}\text { Planning } \\
\text { to Move }\end{array}$ & $\begin{array}{l}\text { Time/ } \\
\text { Bother }\end{array}$ & None & Other \\
\hline $61 \%$ & $25 \%$ & $9 \%$ & $3 \%$ & $1 \%$ & $0_{*}^{\alpha}$ \\
\hline
\end{tabular}

$\begin{array}{ll}76 & 16\end{array}$

6

0

0

0

$(n=186)$

15

58

0

27

0

0

$$
(n=186)
$$


TABLE 9.3.B. Reason Not to Invest in Energy Conservation Measures, by Type of Residence

Number of Homeowners

(in 1000s) Heating

Fuel Electric ( $n=1073$ )

Reason Not to Invest

Types of Residence

Single Family

Detached $(n=897)$

2-4 Family Home-

Duplex-Townhouse

$(n-20)$

Building with More

that 4 Units $(n=11)$

Mobile Home/Trailer

$(n=145)$

Don't Planning Time/

$\frac{\text { Cost }}{60 \%} \quad \frac{\text { Need }}{27 \%} \quad \frac{\text { to Move }}{8 \%} \quad \frac{\text { Bother }}{3 \%} \quad \frac{\text { None }}{1 \%} \quad \frac{\text { Other }}{0 \%}$

$\begin{array}{ll}73 & 17\end{array}$

10

0

0

0

$15 \quad 58$

0

27

0

0

54

37

6

01

2

TABLE 9.4.A. Reason Not to Invest in Energy Conservation Measures, by Amount Spent by Homeowners During the Past Two Years to Reduce Energy Use

Number of Homeowners

(in 1000s) All

Heating Fuels ( $n=1304$ )

Amount Spent

$\$ 0 \quad(n=556)$

$\$ 1-\$ 500 \quad(n=366)$

$\$ 501-\$ 1000 \quad(n=117)$

$\$ 1001-2000(n=100)$

$\$ 2001+(n=165)$
Reason Not to Invest

\begin{tabular}{|c|c|c|c|c|c|}
\hline & Don't & PTanning & Time 7 & & \\
\hline Cost & & to Move & 8other & None & Other \\
\hline $59 \%$ & $30 \%$ & $7 \%$ & $4 \%$ & $0 \%$ & $1 \%$ \\
\hline 59 & 20 & 13 & 5 & 2 & I \\
\hline 61 & 29 & 6 & 0 & 4 & 0 \\
\hline 70 & 16 & 10 & 2 & 2 & 0 \\
\hline 59 & 30 & 4 & 5 & 0 & 2 \\
\hline
\end{tabular}


TABLE 9.4.B. Reason Not to Invest in Energy Conservation Measures Amount Spent by Homeowners During the Past Two Years to Reduce Energy Use

\begin{tabular}{|c|c|c|c|c|c|c|}
\hline \multirow{2}{*}{$\begin{array}{c}\text { Number of Homeowners } \\
\text { (in loo0s) Heating } \\
\text { Fuel Electric }(n=765) \\
\text { Amount Spent }\end{array}$} & \multicolumn{6}{|c|}{ Reason Not to Invest } \\
\hline & Cost & $\begin{array}{l}\text { Don't } \\
\text { Need }\end{array}$ & $\begin{array}{l}\text { PTanning } \\
\text { to Move }\end{array}$ & $\begin{array}{l}\text { Timel } \\
\text { Bother }\end{array}$ & None & Other \\
\hline$\$ 0 \quad(n=333)$ & $56 \%$ & $34 \%$ & $6 \%$ & $3 \%$ & $0 \%$ & $1 \%$ \\
\hline$\$ 1-\$ 500 \quad(n=232)$ & 56 & 23 & 11 & 6 & 2 & 2 \\
\hline$\$ 501-\$ 1000 \quad(n=81)$ & 62 & 30 & 2 & 0 & 6 & 0 \\
\hline$\$ 1001-2000 \quad(n=54)$ & 74 & 9 & 10 & 4 & 4 & 0 \\
\hline$\$ 2001+(n=66)$ & 68 & 23 & 5 & 5 & 0 & 0 \\
\hline
\end{tabular}




\section{DISTR IRUTION}

No. of

Copies

OFFSITE

2 T. Oliver

Bonneville Power Administration MS / KRR

Office of Conservation

1002 N.E. Holloday Street

P.0. Box 3621

Portland, OR 97232

2 L. Saito

Bonneville Power Administration KRP

1002 N.E. Holloday Street

P.0. Box 3621

Portland, OR 97232

$F$. Abel

Senior Economist

Office of Building \& Comunity Systems

U.S. Department of Energy

Forrestal Building CE-11

1000 Independence Ave., S.W.

Washington, DC 20585

2 DOE Technical Information Center
No. of

Copies

ONSITE

DOE Richland Operations Office

J. J. Sutey

24 Pacific Northwest Laboratory

D. L. Ivey (10)

B. M. Bailey

M. P. Hattrup

$R$. T. Nordi

S. A. Shankle

B. L. Mohler

3. M. Fang

J. Callaway

Publishing Coordination MH (2)

Technical Report Files (5) 
.

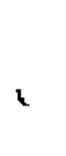

